\title{
Van klinisch verblijf naar vervangende zorg : een onderzoek naar ontslagbelemmerende factoren bij lang opgenomen patienten in psychiatrische ziekenhuizen
}

Citation for published version (APA):

Haveman, M. J. (1987). Van klinisch verblijf naar vervangende zorg : een onderzoek naar ontslagbelemmerende factoren bij lang opgenomen patienten in psychiatrische ziekenhuizen. [, Maastricht University]. Rijksuniversiteit Limburg. https://doi.org/10.26481/dis.19870702mh

Document status and date:

Published: 01/01/1987

DOI:

10.26481/dis.19870702mh

Document Version:

Publisher's PDF, also known as Version of record

Please check the document version of this publication:

- A submitted manuscript is the version of the article upon submission and before peer-review. There can be important differences between the submitted version and the official published version of record. People interested in the research are advised to contact the author for the final version of the publication, or visit the DOI to the publisher's website.

- The final author version and the galley proof are versions of the publication after peer review.

- The final published version features the final layout of the paper including the volume, issue and page numbers.

Link to publication

\footnotetext{
General rights rights.

- You may freely distribute the URL identifying the publication in the public portal. please follow below link for the End User Agreement:

www.umlib.nl/taverne-license

Take down policy

If you believe that this document breaches copyright please contact us at:

repository@maastrichtuniversity.nl

providing details and we will investigate your claim.
}

Copyright and moral rights for the publications made accessible in the public portal are retained by the authors and/or other copyright owners and it is a condition of accessing publications that users recognise and abide by the legal requirements associated with these

- Users may download and print one copy of any publication from the public portal for the purpose of private study or research.

- You may not further distribute the material or use it for any profit-making activity or commercial gain

If the publication is distributed under the terms of Article 25fa of the Dutch Copyright Act, indicated by the "Taverne" license above, 


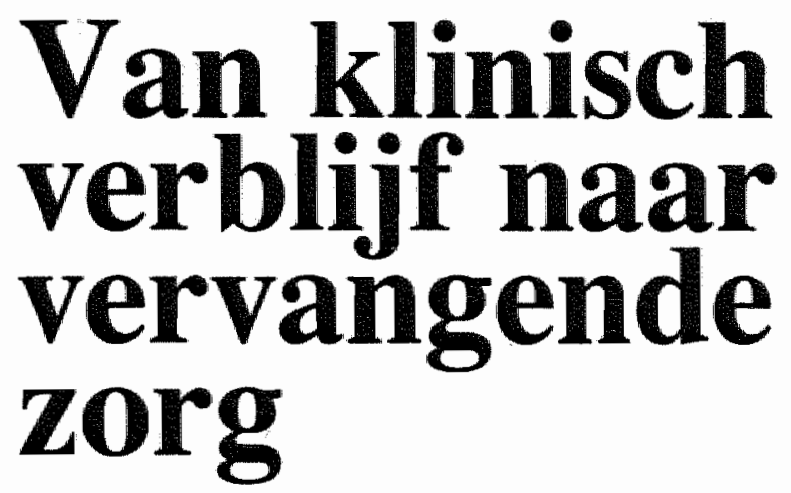

Een onderzoek naar ontslagbelemmerende factoren

bij lang opgenomen patienten in psychiatrische ziekenhuizen.

M.J.Haveman

"Ja, wir wollen Aufwecker und Aerzte sein, doch so, dass die Aufgeweckten nicht wieder einschlafen und die Geheilten nicht an der Heilung zu Grunde gehen."

F. Nietzsche, Die fröhliche Wissenschaft 
Promotores: Prof. dr. F. Sturmans

Prof. dr. F. Vorst

Referenten: Prof. dr. R. Giel

Prof. dr. H. Phillpsen

Prof. dr. M.A.J. Romme

(C) 1987: M.J. Haveman, Maastricht Druk: Quick Service Drukkerij Enschede 


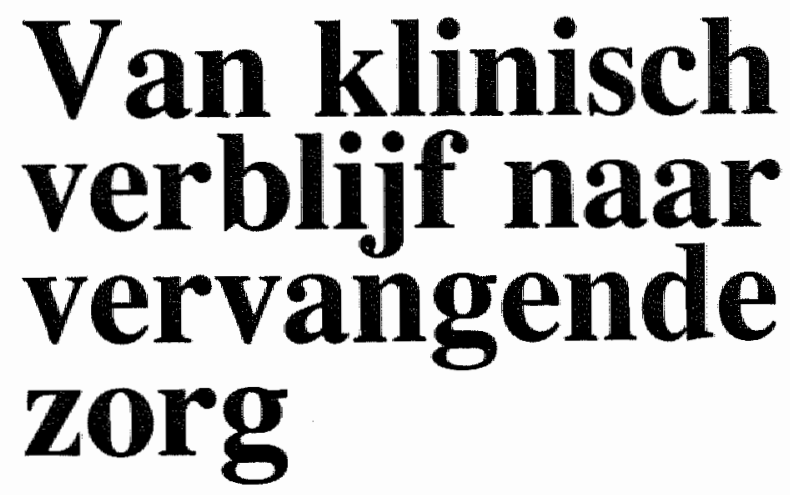

Een onderzoek naar ontslagbelemmerende factoren

bij lang opgenomen patienten in psychiatrische ziekenhuizen.

PROEFSCHRIFT

Ter verkrijging van de graad van doctor in de sociale wetenschappen aan de Rijksuniversiteit Limburg te Maastricht, op gezag van de Rector Magnificus, Prof. dr. F.I.M. Bonke, volgens het besluit van het College van Dekanen in het openbaar te verdedigen op donderdag 2 juli 1987 on 16.00 uur.

door

Meindert san Haveman geboren te Muntendam (Gr.) 
VOOR: HELEEN, MARLEEN, ELLIS

EN JAN-WOUTER 


\section{Voorwoord}

Het voorwoord is het eerste stuk proza in een proefschrift en daarom bij uitstek geschikt on de eenzame positie van de promovendus op de kaft van een dissertatie direct te corrigeren. Het verschijnen van dit proefschrift was zonder de waardevolle bijdrage van een groot aantal personen niet mogelijk geweest. Zonder de pretentie van volledigheid te hebben zal ik proberen de bijdrage van iedereen zoveel mogelijk binnen het proces van onderzoek weer te geven, - van de formulering van de vraagstelling tot en met het typen van de dissertatie.

De voorgeschiedenis van een onderzoek is veelal lang, en begint met het constateren van een probleem en het stellen van eenvoudige vragen. Dit geldt ook voor dit onderzoek.

Ik kan mij nog m'n verbazing herinneren, toen ik in 1975 bij een stage-onderzoek max de doelgroep van enkele psychiatrische tussenvoorzieningen ontdekte, dat in de Nederlandse psychiatrische ziekenhuizen veel patiënten daar zeer lang verbleven. Na afsluiting van de studie medische sociologie in $1976 \mathrm{kreeg}$ ik bij de afdeling onderzoek van de Geneeskundige Hoofdinspectie voor de Geestelijke Volksgezondheid de gelegenheid, om meer informatie te vergaren over de kenmerken, de leefsituatile en de ontslagprognose van lang opgenomen patiënten. Het waren vooral Ans de Graaf, Wout Hardeman en Jan Van Borssum-Waalkes waar ik toen met inhoudelijke vragen terecht kon.

Het idee om een onderzoek uit te voeren nar de mogelijkheden van vervangende zorg voor lang opgenomen patiënten, maar tevens om een aantal factoren te bestuderen die het ontslag van patiênten belemmeren $c . q$. bevorderen, werd echter pas concreet na mijn overgang naar de vakgroep Epldemiologie en Gezondheidszorgonderzoek van de R.U.Limburg. Vooral de hoogleraren Fred Vorst en Ferd sturmans van deze vakgroep hebben mij met raad en daad bijgestaan bij de voorbereiding en uitvoering van het onderzoek. Daarvoor ben ik hun zeer erkentelijk.

Het onderzoek werd mogelijk gemaakt door een subsidie van het Ministerie WVC, waardoor Nico Poelijoe, klinisch psycholoog, aan 
het onderzoeksproject kon deeinemen. Zijn bijdrage in de verschillende fasen van het project was van essentiëel belang voor het slagen van het onderzoek. En het verdient bijzondere vermelding, dat de 1 in dit onderzoek gehanteerde patientenvragenlijst (VOL III) vooral door her is ontworpen.

Bij de eerste toetsing van de vragenijjsten in het vooronderzoek hebben wj veel medewerking gekregen van de verpleegkundigen, hoofdbehandelaars en patienten van het P.M.S.Vujverdal te Maastricht. Dat geldt tevens voor de directeur patientenzorg van deze instelling, Aart Jan Vrijlandt. Mijn dank gaat vooral ook uit naar Jan Luchtman en Detlef Petry voor de introductie van het vooronderzoek binnen de kliniek, en hun critische evaluatie van de conceptvragenlijsten.

Zowel de Nederlandse Vereniging van Beschermende Woonvormen als de Sectie Psychiatrische ziekenhuizen van de Nationale ziekenhui raad waren bereid om het onderzoek bij hun lidinstellingen te introduceren. De steun van deze koepelorganisaties was van groot belang voor de deelname van de voorzieningen aan dit onderzoek. De samenwerking met de deelnemende instellingen aan het landelijk onderzoek was prettig. Ik wil op deze plaats graag de betreffende directies, contactpersonen op medische administraties, en niet te vergeten de behandelaars, verpleegkundigen, patienten en bewoners danken voor de moeite die zij gedaan hebben om dit onderzoek mogelijk te maken. Alle inspanningen van de medewerkers, zoals het invullen van de vragenlijsten, moesten naast de gebruikelijke werkzaamheden gedaan worden en waren voor het slagen van de uitvoering van dit onderzoek onontbeerlijk.

Maax ook de in tijdelijke dienst van alt onderzoek werkende groep van 10 B-verpleegklundigen heeft een belangrijk aandeel in de uitvoering van het onderzoek gehad. Alhoewel zij slechts in beperkte mate geinformeerd waren over de mogelijke uitkomsten van dit onderzoek, om informatie-bias zoveel mogelijk te voorkomen, hebben $z i j$ zich goed van hun interviewtaak gekweten. ook hebben met veel kundigheid en gedula Marian Maaskant en Frans Tan meegeholpen bij de verwerking en statistische analyse van de gegevens. 
De landelijke Begeleidingscommissie van dit onderzoek heeft het verloop van het onderzoek steeds critisch en constructief gevolgd. De Begeleidingscommissie bestond uit de volgende leden: prof.dr.H.Van Ande1, voorzitter, NZI en Instituut voor Algemene Gezondheldszorg; drs.o.Brook, afdeling onderzoek van de GHIGV; ars.C.Kat, Hoofdafdeling geestelijke gezondheidszorg, Ministerie WVC; drs.R. Dosterhof, afdeling organisatie, psychiatrisch ziekenhuis Veldwijk; en prof.dr.F.Vorst, vakgroep Epldemiologie \& Gezondheidszorgonderzoek van de R.U.Limburg.

Waardevollge suggesties nar aanleiding van een conceptversie van dit proefschrift heb ik gekregen van Paul knipschild thoogleraar Epidemiolagie, R.U.Limburg).

$\mathrm{U}$ zou dit onderzoeksverslag niet kunnen lezen als het niet uitgetypt was. Gezien de orvang zal dit een niet altijd even stimulerend karwei geweest zijn. Mijn dank gaat dan ook uit naar Thum Aarts en Riny Bodifée, medewerkers op het secretariaat van de vakgroep Epidemiologie \& Gezondhellasorgonderzoek.

Vanaf de geboorte hebben mijn ouders met wisselend succes geprobeerd het taalgebruik van hun zoon te verbeteren. En zij waren wederom bereid bij dit proefschrift een poging te wagen. veel belangrijker dan deze bijdrage is echter hun vertrouwen en vriendschap. 

2. De chronisch psychiatrische patiënt 10

3. De lang opgenomen patient (1.0.p.) 20

3.1. Lang opgenomen patienten in psychiatrische ziekenhuizen

3.2. Lang opgenomen patiënten in psychiatrische dagziekenhuizen

3.3. Lang opgenomen patiënten in beschermende woonvormen

4. Vraagstelling

4.1. Lang opgenomen patiënten (definitie)

4.2. Psychlatrische ziekenhuizen

4.3. Ontslag naar verwangende zorg

4.4. Ontslagbelemmerende c.q. -bevorderende factoren

5. Onderzoeksplan

5.1. Normering van de afhankelijke variabele: mogelijkheid van vervangende zorg

5.1.1. Directe normering

5.1.2. Indirecte normering

5.2. Design

6. Afgelelde vraagstellingen

6.1. Patiëntfactoren

6.1.1. Vaardigheden

6.1.2. Psychiatrische diagnose 50

6.1.3. Geestelijke handicaps 51

6.1.4. Gevaar voor zichzelf of anderen 52

6.1.5. Demografische en juridische factoren 53

6.1.6. Attitude van patiënten ten aanzien 
6.2. Afdelings- en instellingsfactoren 56

6.3. Gezins- en huisvestingsfactoren 60

7. Operationalisering en vragenlijsten 66

7.1. VragenIijst Onderzoek Long-stay I (VOL I) 67

7.2. Vragenlijst Ondexzoek Long-stay II (VOL II) 68

7.3. Vragenlijst onderzoek Long-stay III (VOL III) 69

7.3.1. VOL III: versie psychiatrische dagzieKenhuizen en beschermende woonvormen 70

8. Ontwikkeling en toetsing wan de indices van de VOL II

8.1. Validiteitscontrole van indices

8.1.1. De Beoordelingsschaal voor Oudere Patiënten (BOP)

8.1.2. De intrinsieke validiteit van de VOL II-indices; gegevens van vijf psychiatrische ziekenhuizen

8.2. Betrouwbaarheidscontrole van indices 82

9. Het patiëntinterview (VOL III) 90

9.1. Index "Houding Ontslag" (H.O.) en "Houding Instelling/Afdeling" (H.I.) 92

9.2. Validiteit

10.1. Steekproeftrekking bij de algemene psychiatrische ziekenhuizen

10.1.1. Uitvoeringsprocedures

10.1.3. Representativiteit

10.2. Steekproeftrekking bij de psychiatrische dagziekenhuizen 
10.3. Steekproeftrekking bij de beschermende woonvormen

10. 3.1. Respons

10.3.2. Representativiteit

114

DEEL IV - RESULTATEN

11. Oordeel van hulpverleners over mogelijkheden van vervangende zorg; resultaten voor de criteriumvariabele

12. Toetsing van hypothesen

12.1. Vaardigheden (bivariate toetsing)

12.1.1. Basale zelfredzaamheid (BZR)

12.1.2. Potentieel sociale vaardigheden (PSV)

128

12.1.3. Interne sociale integratie (ISI)

12.1.4. Externe sociale integratie (ESI)

12.2. Vaardigheden (multivariate analyse)

12.3. Psychiatrische diagnose

12. 4. Gevar voor zichzelf en anderen

12.5. Leeftijd en de hypothesen $1 \mathrm{t} / \mathrm{m} 8$

12.6. Leeftija en de ontslagattitude van de patiênt 168

12.7. Juridische sitwatie 169

12.8. Verblijfiduur

12.9. Houding t.a.v. afdeling/instelling en ontslag 186

12.10. Behandelingsbeleid en de ontslagattitude van de patiënt

12.11. Doorstroming op de afdeling 194

12.12. Volledigheid thuismilleu

12.13. De invloed van enkele variabelen tezamen op het oordeel over verwangende zorg; een multivariaat model 
13.1. Vaardigheden

13.2. Structuur en houding van het thuismilieu

13.3. Paychiatrische diagnose

13.4. Sulcidaal, agressief gedrag en onvrijwillig verblijf

13.5. Leeftijd

13.6. Houding van patiènten $t \cdot a \cdot v$. ontslag en de afaleing

- Literaturr

- Bijlagen:

1. Vragenlijst onderzoek Long-Stay I (VOL I)

2. Vragenlijst Onderzoek Long-Stay II (VOL II)

3. Vragenlijst Onderzoek Long-Stay III (VOL III)

4. Resultaten van de factoranalyse over de BOP-items; vooronderzoek

5. Respors van beschermende woonvormen en psychiatrische dagziekenhuizen

6. Correlatiematrix voor de variabelen van de multiple logistische regressie

7. Gebruikte afkortingen

- Curriculum Vitae 
DEEL I - ALGEMENE INLEIDING

\section{Inleiding}

Nederland telt een 40-tal algemene psychiatrische ziekenhuizen (a.p.z.-en) warin personen met ernstige en veelal langdurige psychische problemen worden opgenomen. In deze voorzieningen worden per jaar 17 opnemingen gerealiseerd per 10.000 Nederlanders. Op het tijdstip van opname verkeren deze patienten in een stadium van hevige angst, ontreddering, waan, verwaarlozing of tegen zichzelf of anderen gekeerde agressie wartegen familieleden, huisarts en de professionele extra- en semi-murale hulpverleners in de geestelijke gezondheidszorg machteloos staan. In een dergelijke situatie bestaat behoefte an tijdelijke beschutting en deskundige hulpverlening, - niet alleen om betrokkene zelf tot rust en herstel te laten komen mar tevens om gericht te kunnen werken aan eventuele spanningen binnen het natuurlijke relatiesysteem (gezin, familie, vriend/vriendin). Deze laatste functie is van belang, zowel am optimale kamsen te scheppen voor de terugkeer van betrokkene, als ook om nieuwe escalatile van problemen binnen dit systeem tegen te gaan. In principe zou dan ook reeds bij het begin van de opname met de psychiatrische nazorg begonmen dienen te worden.

Voor een aantal patiënten resulteert een psychiatrische opname echter in een min of meer definitief verblijf, waarmee een zeker eindpunt voor "chronisch psychiatrische patienten" bereikt lijkt te zijn. Zo bleek uit een studie van Giel e.a. (1978) dat van de in 1970 opgenomen patiënten 78 na 4-4,5 jaar nog steeds zonder onderbreking in het psychiatrisch giekenhuis verbleef. Haveman (1980c) kwam voor het landelij jk opnamecohort van 1973 tot 5,78 continue verblijfpatienten na een follow-up-periode van 3-4 jaar. Helaas ontbreken meer recente cijfers.

In het onderhavige onderzoek is nagegaan voor hoeveel patiënten, ondanks hun langdurig kilnisch verblijf, nog mogelijkheden voor andere, vervangende zorg bestaan; en welke factoren van belang 
zijn voor hulpverleners om lang opgenomen patienten wel of niet daarvoor in aanmerking te laten komen.

Hiermee zijn tevens twee begrippen geIntroduceerd, namelijk de "chronisch psychiatrische patient" en de "lang opgenomer patient" "die in het vervolg kort zullen worden toegelicht.

\section{De chronisch psychiatrische patient}

Over de betekenis van het begrip "chronisch psychiatrische patient" bestat in de geestelijke gezondheidszorg weinig overeenstemming. Het is een term in het verbale pakket van de hulpverlener die veelal zeex voorzichtig wordt gehanteerd gezien de impliciete prognose, weinig specifieke informatie en de negatieve behandelingsimplicaties.

"Chronisch" wordt in het Pinkhof Geneeskundig Woordenboek (1984) omschreven als: "sluipend, zich langzaam ontwikkelend (al of niet ma een acuut begin) en gewoonlijk van lange duur". In de Webster (1984) wordt daarbij aangevuld dat ook aandoeningen die gekenmerkt worden "by frequent occurrence over a long time, and often by slowly progressing seriousness ..." onder deze noemer vallen. ondanks de semantische en pragmatische problemen bij het hanteren van het begrip "chronisch" wordt deze term regelmatig in de geestelijke gezondheidszorg gebruikt, om in weinig woorden al generaliserend een groep langdurig zorgafhankelijke personen met psychische stoornissen te benoemen. Het is daarom de moeite ward om na te gran vanuit welke concepten en invalshoeken het fenomeen "chroniciteit" in de psychiatrie wordt benaderd.

\section{Een yoorbeeld}

In verband met een onderzoek nar de potentièle doelgroep var beschermende woonvormen werd aan vier geneegheer-directeuren van psychlatrische zilekenhuizen de vraag gesteld hoe zij het begrip "chronlsch psychiatrische patiënt" zouden definiëren, waarbij de vier antwoorden als volgt konden worden samengevat: 
"1 - iemand die met een defect is genezen;

2 - personen op wie alle mogelijkheden van rehabilitatie $z i j n$ vastgelopen, maar zekerheld hierover bestaat nooit;

3 - chronische patiënten zljn aanwijzingen van het onvermogen van behandeling; en

4 - patiënten die lang en frequent zijn opgenomen".

(Haveman, 1975)

Bij deze kleine steekproef uit het universum van mogelijke antwoorden blijkt reeds een veelheld van invalshoeken te bestaan. zoals bij het chroniciteitsbegrip in de somatische gezondheidszorg, waar zowel arthritis als huideczeem tot de chronische ziekten worden gexekend, bestaat bij hulpverleners in de geestelijke gezondheidszorg geen overeensteming over chronische ziekten gelet op criteria als diagnose, etiologie, handicaps, beloop en duur van de aandoening. Afhankelijk van voorkeur en invalshoek staat soms het ene aspect central in de definitie, soms het andere.

Kenmerkend voor het chroniciteitsbegrip in de geneeskunde is verder dat het gaat om aandoeningen warbij de kans om op korte termijn spontaan en volledig te herstellen gering is en waarvoor de behandelingsmethodieken slechts ten dele effectief zijn gebleken. Zo menen Pepper e.a. (1981) dat ". the term "chronicity" may reflect merely the undeveloped state of our own art". In de hierboven gegeven tweede en derde definitile komt dit aspekt aan de orde.

Deze invalshoek, de beperkte doeltreffendheid van psychiatrische interventie, wordt ook genoemd in een standpuntbepaling van de Canadian Psychiatric Association (Watt \& El-Guebaly, 1981) ten aanzien van chronisch psychiatrische patiënten. Het commentaar wordt toegespitst op bepaalde groepen patiénten.

"Some psychiatric entities, such as various forms of dementia, are unresponsive to known methods of therapy. We have all known. however, patients whose prognosis was considered to be hopeless but who improved and did not join the ranks of the chronlc. sometimes patients fail to get well because they are not treated 
optimally and that in turn may relate to inadequate evaluation. Schizophrenia and, less frequently, manic depressive illness contribute heavily to the diagnostic categories found in chronic mental patients. Other significant special groups include the elderly, institutionalized mentally 111 , the mentally retarded, emotlonally disturbed children and alcoholics, and drug addicts with or without organic brain damage".

In dit verband zijn er psychiaters die zich - zelfpijnigend "specialisten in chronische zilekte" noemen. Zo schreef Emanuel (1982): "De psychiatrie bestaat bijna geheel uit de behandeling van chronische of periodiek terugkerende ziekten. In de behandeling van neurosen heeft dit geleid tot een veelheid van theorie en behandelingssystemen die noch hun geldigheid noch hun doeltreffendheid hebben bewezen ... De zwaardere psychiatrische stoornissen, die de patienten nar het psychiatrische ziekenhuis leiden, zijn vaak beklagenswaardig chronisch van aard. Herstel van een acute episode van schizofrenile resulteert voor de patiënt vaak in een verarma leven, ver beneden zijn eerdere mogelijkheden. Wel is het herstel van een depressie of een manische episode doorgaans volledig. Organisch psychiatrische stoornissen zijn min of meer onbeinvloedbaar" " En hij eindigt met de stelling:" Wij psychiaters ajn in werkelijkheld specialisten in chronische ziekten".

Hoe weinig genuanceerd deze uitspraken ook mogen zijn, we kunnen er in ieder geval uit afleiden dat het weinig zin heeft om "chronisch psychiatrische patiëten" alleen te willen onderscheiden op basis van aard en duur van de psychiatrische problematiek en daarmee samenhangend, de doeltreffendheid van de behandeling. In de vierde definitie wordt en betrekkelijk nieuw criterium geintroduceerd. Niet de aard en duur van de "ziekte" mar de plaats en dur van de behandeling, namelijk langdurige behandeling in een psychiatrisch ziekenhuis, stat in de definitie centraal. Dat betekent dat twee conceptueel verschillende zaken in eén begrip worden samengebracht, namelijk beloop en aard van een psychische stoornis en het opname- en ontslagbeleid van een insteling. Met name in overheidsbeleid en onderzoek wordt 
"chroniciteit van een psychische stoornis" vaak zonder verdere argumentatie geoperationaliseerd door "chronische hospitalisatie" (Kris e.a., 1971), dus door het te koppelen aan opnameduur en -frequentie. In een rapport van de Ad Hoc Comittee on the Chronic Mental Patient (1978) in de vs wordt bijvoorbeeld Bachrach"s definitie van de chronisch psychiatrische patient gehanteerd: "those individuals who are, have been or might have been, but for the delinstitutionalization movement, on the rolls of long-term mental institutions, especially state hospitals". De problemen van een dergelijke definitle, niet alleen voor onderzoek mar ook voor het overheidsbeleld, liggen voor de hand. vooral in landen en in een periode, warin de nadruk wordt gelegd op opvang en begeleiding van langdurig zorgafhankelijke personen, indien mogelijk, door ambulante en semimurale voorzieningen, Is opnameduur geen zinvolle indicator voor chroniciteit. Redilich en Kellert (1978) wijzen in dit verband op de verschuivingen in het opnamepatroon in de VS van langdurige opnemingen in de 50-er jaren naar frequente opnemingen van patiënten in de 70-er jaren. ook in Nederland wordt een dergelijke trend onderkend (Brook, 1984).

Alhoewel er weinig aanwijzingen $z i j n$ dat de zorgbehoefte van psychiatrische patienten in de tijd veel is veranderd, bestaat in het huidige opname- en ontslagbeleid wel de tendens om patiënten in perioden van betrekkelijke rust en in fasen met weinig symptomen buiten de kliniek te laten verblijven (schema 1 ).

Schema 1: Hospitalisatie van een psychotische patiënt in de jaren 50 en 80 .
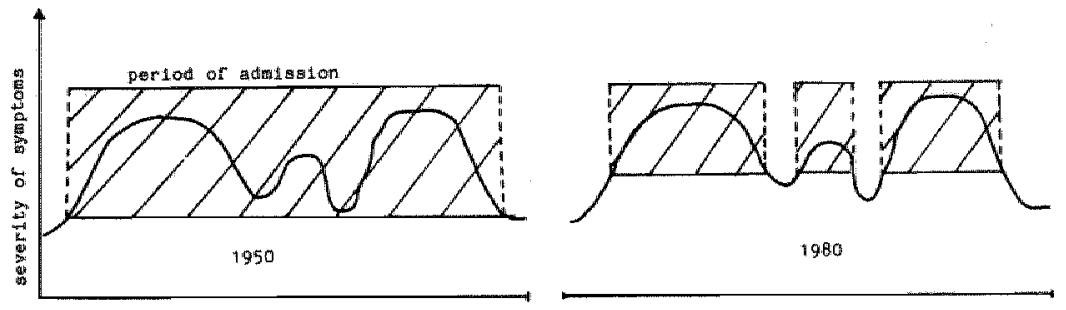

(Haveman, 1986). 
Daar de opnameduur een betrekkelijk eenvoudig en objectief te meten variabele is, wordt in onderzoek "de chronische patient" valk geoperationaliseerd door intramurale verblijfsduur. De begrippen "chronisch psychiatriache patient" en "lang opgenomen patient" worden daarbij als wederzijds uitwisselbaar beschouwd. De chronische patiënt 1 s of was lang opgenomen, en de langdurig opgenomere is een chronische patient.

Bij het afbakenen van "chronische" populaties qua verblijfsduur kont men reeds bij een kleine selectie in de desbetreffende 11 teratuur aanzienlijke verschillen tegen. Sommigen kiezen voor een periode van een half jaar of langer als afkappunt (Visiecommissie St. Bavo, 1973; Hirsch e.., 1973), anderen voor een periode van éen jaar (Achte steinbäck, 1966), twee jaar (Brown, 1960; Brown e.a.. 1958; Giel e.a., 1978) of zelfs vijf jaar of langex (Pokorny e.a., 1976).

Alhoewel de "ndicator "verblijfsduur" voor chroniciteit de charme heeft van een betrekkelijk eenvoudig te operationaliseren variabele, worden met deze operationalisering twee nieuwe meetproblemen geintroduceerd. Zo ontstaat een validiteitsprobleem (met de verblijfsduur wordt ook het opname- en ontslagbeleid van instellingen gemeten), maar tevens is de mate (= verblijfsduur) voor chroniciteit kwetsbaar en gevoelig voor administratieve veranderingen. Met het laatste wordt bedold dat door administratieve handelingen binnen de organisatie, onbedoeld de schijn kan worden gewekt van ontslag, terwijl de opnamesituatie van de patiënt zelf nauwelijks gewijzigd is. Veranderende regelingen voor de financlering van de zorg bijvoorbeeld in verband met vacanties, kortaurende behandeling in een ziekenhuls, interne overplaatsingen, aparte erkenningen van afdelingen als verpleeghuis of zwakzinnigeninrichting en korte plaatsingen woor dagbehandelingen op de afdeling, kunnen via de registratile de indruk geven wan beëindiging van "chronische hospltalisatie". In de statistieken kan hlerdoor de suggestie van dalende "chroniciteit" worden gewekt. Weinstein e.a. (1973) merken hierbij op "... that the reduction in "chronicity" could be a statistical illusion, based on brief and artificial interruptions of essentially continuous periods of iliness". 
De invalshoek "verblijfsiuur" in het chroniciteitsbegrip kent dus de volgende beperkingen:

(1) er ontbreekt een nadere omschrijving van "chronische" patiënten naar kenmerken;

(2) patiënten die buiten de muren van de instelling verblijven worden ook systematisch buiten de definitie gelaten, al verschillen $z i j$ verder niet van hun intramurale lotgenoten:

(3) ook vallen patiënten met korte opnameduren maar met langdurige en hardnekkige problematiek buiten de doelgroepomachrijving: terwijl

(4) zonder verdere specificatie bijwoorbeeld de volgende patienten in psychiatrische ziekenhuizen wel onder de definttie zouden vallen zoals:

- diep geestelijk gehandicapten.

- demente bejaarden.

- alcohol- en drugsverslaafden die onder de zelfbescherming van een rechterlijke machtiging van hun verslaving af willen.

- neurotische personen die gemotiveerd mar langdurig aan gedragstherapieën en therapeutische gemeenschappen deelnemen,

- (bijna volledig) herstelde ouderen zonder huisvesting bij eventueel ontslag.

Alhoewel de toelichting op de verschillende aspecten van het begrip "chroniciteit" heeft bijgedragen tot meer informatie, bleef het een groot probleem om de ernstig gestoorde en langdurig zorgafhankelijke psychiatrische patient nauwkeurig en voor iedereen herkenbaar te onderscheiden binnen het totaal van personen met psychische stoornisisen. Vanaf het midden van de zeventiger jaren zijn dan ook verschillende initiatieven ontstaan om "chroniciteit" op meerdere assen, op persoonsniveau, en - soms ook onafhankelijk van opnameduur te definiëren. Centraal daarbij staan de aard, ernst en duur van de psychische stoornis, maar ook de handicaps en sociale beperkingen in verband met zelfverzorging, relatievorming en verwacht rolgedrag: thuis, in beroep, vrije tijd e.d. (Goldman e.a., 1981; Minkoff, 1978; Giel e.a., 1980; Wiersma e.a., 1983; De Jong, 1984). 
Minkoff (1978) onderscheldt arie assen, namelijk diagnose, beperkingen an gedrag en opnameduur:

"- persoma who are severely mentally ill (defined by diagnosis),

- those who are mentally disabled (defined by level of disabili(y), and

- those who are chronic mental patients (defined by duration of hospltalization)".

In iets gewijzigde vorm werd dit onderscheid ook gehanteerd in het adries aan de Minister voor Volksgezondheid in de vs over het te voeren beleid ten aanzien van chronisch psychiatrische patienten ( $z$ ie scherna 2).

Schema 2: Aspecten van chroniciteit.

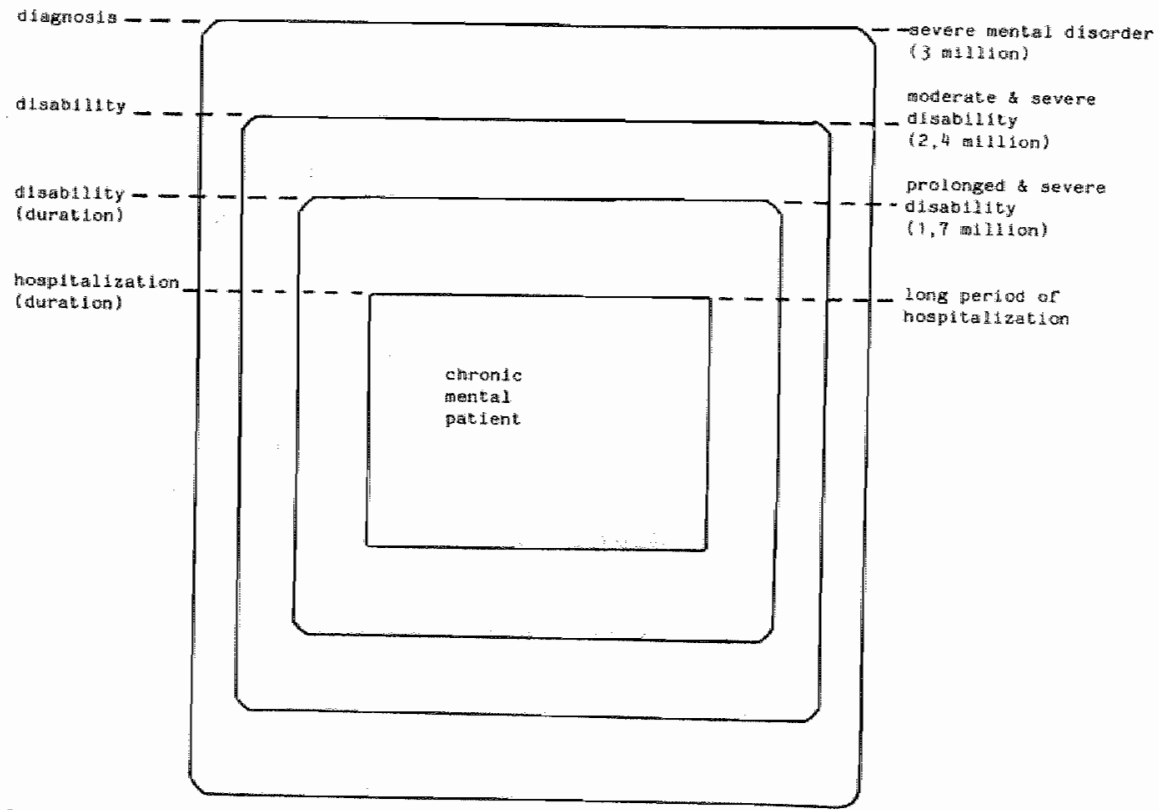

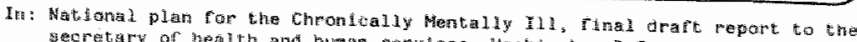

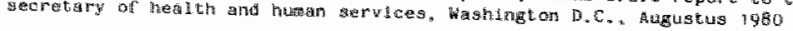


In dit schema wordt het begrip "chronisch psychiatrische patiënt" alleen gereserveerd voor personen met langdurige en ernstige psychiatrische stoornissen en anzienlijke beperkingen in vaardigheden en langdurige opname. Volgt men deze indeling, dan kunnen "chronisch psychiatrische patiënten" worden omschreven als: "... persons who suffer severe and persistent mental or emotional disorders that interfere with their functional capacities in relation to such primary aspects of daily life as selfcare, interpersonal relationships, and work or schooling, and that often necessitate prolonged hospital care" (Goldman e.a. . 1981 ).

Alhoewel er zeker een bepaalde afhankelijkheid zal zijn tussen diagnose, beperkingen in gedrag en opnameduur, verdient het 0.1 . de voorkeur deze aspecten onafhankelijk van elkaar in de vorm van een Venn-diagram te onderscheiden (schema 3 ).

Schema 3: Langdurige problemen bij psychische stoornissen Vennaiagram).

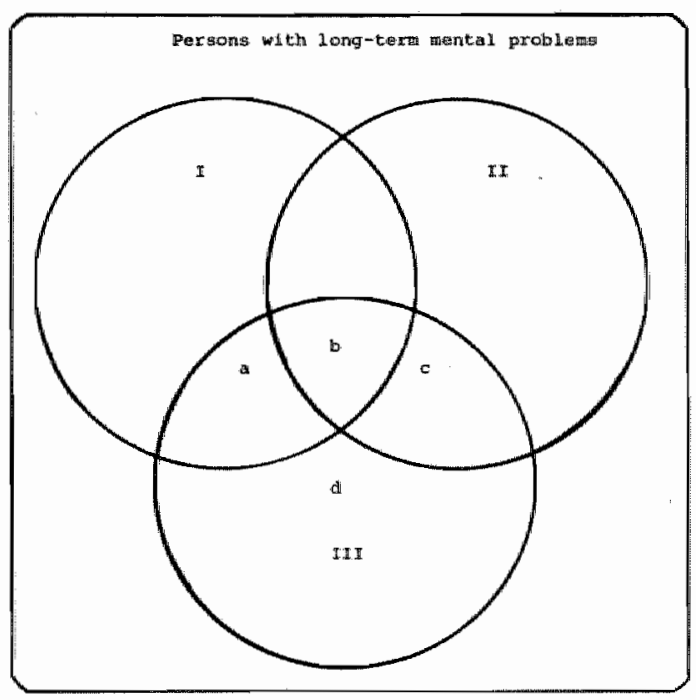

\footnotetext{
1. Severe mental a isonder of long dutation

II. Matarate or severe al alditity of lang daration

in. Leng-stay in mental haspitial

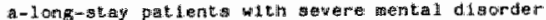

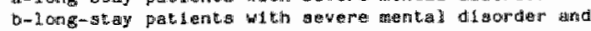
mot ariate or gevere diability

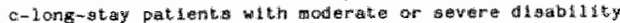

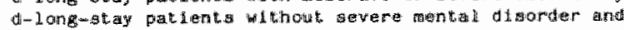
whout moderate ar gievere disability.
} 
ook dit schema roept weer de nodige vragen op. Als we naar de linker cirkel (I) kijken:

- welke psychiatrisch-diagnostische hoofdgroepen worden daartoe gerekend,

- met behulp van welke diagnosesystemen worden deze hoofigroepen vervolgens bepaala.

- hoe wordt de ernst wan een psychiatrische stoornis gedefinieerd en gemeten, en wie bepadt de ernst: de psychiater of de patient,

- wat is langdurig, - een half jaar, twee jaar of vijf jaar; en wat zijn de problemen bij het bepalen van het startpunt van de psychische problematiek (Slooff, 1983).

- moet het beloop continu zijn, of mag het ook episodisch zijn met "up "s" en "down" s"?

Dergelijke kanttekeningen zijn ook bij de rechter cirkel (II) te plaatsen:

- welke beperkingen in memselijk functioneren vallen onder dit begrip (1. ichamelijke handicaps, zelfredzaamheid vertaald in ADL-functies, psychische functiestoornissen, sociale vaardigheden, of vervulien van sociale collen).

- via welke instrumenten wordt dit gemeten,

- wat zijn ernstige beperkingen, en welke zijn minder ernstig.

- hoe lang moeten de beperkingen bestaan om als langdurig genoema te worden?

In het onderhavige onderzoek is niet de "chronisch psychiatrische patiënt" onderwerp van studie, de intersectie van cirkels I en II in schema 3 , mar de "lang opgenomen patiênt" ( $1.0 . p *$ ), dus de personen in cirkel III. Het gaat om personen met langdurige psychische problemen waarvan niet noodzakelijk vaststat dat ledereen een ernstige psychiatrische stoornis heeft en gekenmerkt wordt door zeer ingrijpende gedragsbeperkingen als gevolg van handicaps.

In een eerste aanzet zou men deze groep als volgt kunmen onderscheiden (zie Venn-aíagram): 
a - lang opgenomen patienten met een ernstige psychiatrische stoornis;

b - lang opgenomen patiënten met een ernstige psychiatrische stoornis en met matige tot ernstige handicaps;

c - lang opgenomen patiënten met matige tot ernstige handicaps maar zonder een ernstige psychiatrische stoornis, en

d - lang opgenomen patienten zonder een ernstige pisychiatrische stoornis en zonder handicaps.

In het onderzoek zelf is geen poging ondernomen om een caesuur aan te brengen tussen ernstige en minder ernstige psychiatrische stoornissen. Hiervoor zijn verschillende redenen a an te geven:

- voor het meten en de interpretatie van de ara en de ernst van psychiatrische symptomen waren de onderzoekers onvoldoende geoefend en opgeleid;

- ook de patiëten waarbij in het begin van de opname in verband met de diagnose een redelijke prognose voor herstel bestond (bv. depressie), verbleven op het tijdstip van onderzoek reeds meerdere jaren in de instelling. Met andere woorden: de betrekkelijk goede prognose die in verband met de diagnose op groepsniveau bestond bij eerste opname, was voor deze selecte groep van lang opgenomen patienten veelal niet of in beperkte mate van toepassing:

- bij meer "harde" criteria voor de ernst van ziekte zoals de duur en sterftekansen verschillen de patiënten maar weinig;

- het is moeilijk of zelfs onmogelijk om vanuit de beleving van de problemen door de patiënt zelf aan te tonen dat een langdurige depressie of fobie minder ernstig is dan schizofrenie; en tenslotte:

- het definięren van de ernst van psychlatrische ziekte door handicaps en beperkte vaardigheden biedt voor de groep van veelall oudere, lang opgenomen patienten weinig pexspectief, daar de beperkingen ook onafhankelijk van de psychiatrische ziekte (bv. door ouderdom, lichamelijke handicaps) kunnen voorkomen of geintroduceerd zijn door de gezondheidazorginterventie (bv. medicatie, weinig gelegenheid tot het oefenen van vaardilgheden). 
Het meten van de diagnose bleef in dit onderzoek daarom beperkt tot enkele diagnostische hoofdgroepen. Wel werd meer andacht besteed an het onderscheiden van patiënten naar de aard en mate van hun vaardigheden.

Verderop (hfdst. 6.1.) is aangegeven hoe de psychiatrische diagnose en de gedragsbeperkingen en vaardigheden in het onderzoek werden gemeten. In hoofdstuk 12.1 . wordt vervolgens een poging ondernomen om de bewoners (1.0.p.) van psychiatrische ziekenhuizen, centra voor psychiatrische dagbehandeling en beschermende woonvormen te beschrijuen en te vergelijken an de hand van de verschillende soorten vardigheden.

Bij de verdere uitwerking van het chroniciteitsbegrip is aansluiting gezocht bij het "gebrekkigen-model" zoals het door Giel (1982) exemplarisch wordt geschetst voor lang opgenomen psychiatrische patienten. Volgens Giel telt bimnen het gebrekkigen-model de speclfieke diagnose minder (en tevens de dur en de etiologie van het medisch gedefinieerde probleem). Meestal wordt volstaan met de benoeming van beperkte vaardigheden. Lang opgenomen patlënten ". . zijn doorgaans mensen die moeten leven met een gebrek, in ait gevall een geestelijk gebrek. Ze vervullen niet langer de ziekenrol. Dat wil niet zeggen dat er niets meer voor hen gedaan kan worden. Het is op $z$ " $n$ minst mogelijk om lijden te verzachten of de verergering van een gebrek te woorkomen. Iemand kan bovendien geleerd worden toch weer bepalde sociale rollen op zich te nemen" (Giel, p. 72).

Bij de toepassing van dit model in het onderzoek ging onze interesse ook ult naar vaardigheden die in potentie nog aanwezig zijn, de validitelt en vitaliteit van bepaalde lichamelijke en sociale functies.

3. De lang opgenomen patiënt (1.o.p.)

3.1. Lang opgenomen patienten in psychiatrische ziekenhuizen

In de psychiatrische ziekenhuizen is door jaarlijkse accumulatie een aanzienlijk bestand van lang opgenomen patiënten (1.0.p.) ontstaan. Van de in 1973 in Nederlandse psychiatrische ziekenhui- 
zen opgenomen patiënten verbleef $67 \%$ daar langer dan twee jaar. Het aantal 1.0.p. is in de afgelopen 10 jaar afgenomen. Eind 1982 was 578 , nog steeds meer dan 10.000 patiënten, langer dan twee jaar continu opgenomen, waarvan 3500 patiënten zelfs langer dan 10 jaar. De daling van het aandeel 1.o.p. in een periode van 10 jaar vond vooral plaats bij patienten die reeds zeer lang, namelijk 10 jaar of langer, in een psychiatrisch ziekenhuis verbleven (schema 4).

Schema 4: Het aandeel lang opgenomen patiënten in algemene psychiatrische ziekenhuizen op 31 december $1973 \mathrm{t} / \mathrm{m} \mathrm{1982}$; naar verblijfsduur.

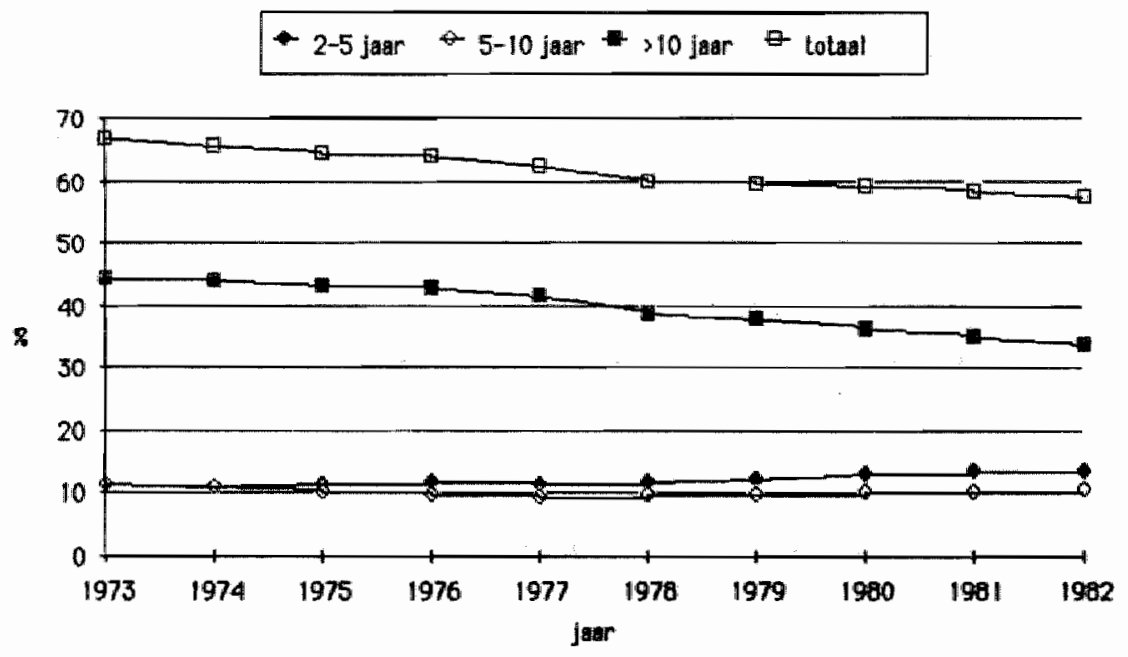

De omvang van de verblijfsduurgroep van 2 tot 5 jaar nam in aantal minder snel af. In de meer recente jaren hebben zij daardoor een steeds belangrijkere plaats gekregen binnen het totale bestand van langverblijvende patiënten. De capaciteit die vrijkwam door uitstroom van zeer lang opgenomen patiëten door sterte of overplaatsing, werd voor een deel weer bezet door "nieuwe langblijvers" . 
Bchema 5: Het aandeel lang opgenomen patienten in algemene psychiatrische ziekenhuzen op 31 december 1973 t/m 1982; naar psychiatrische diagnose.

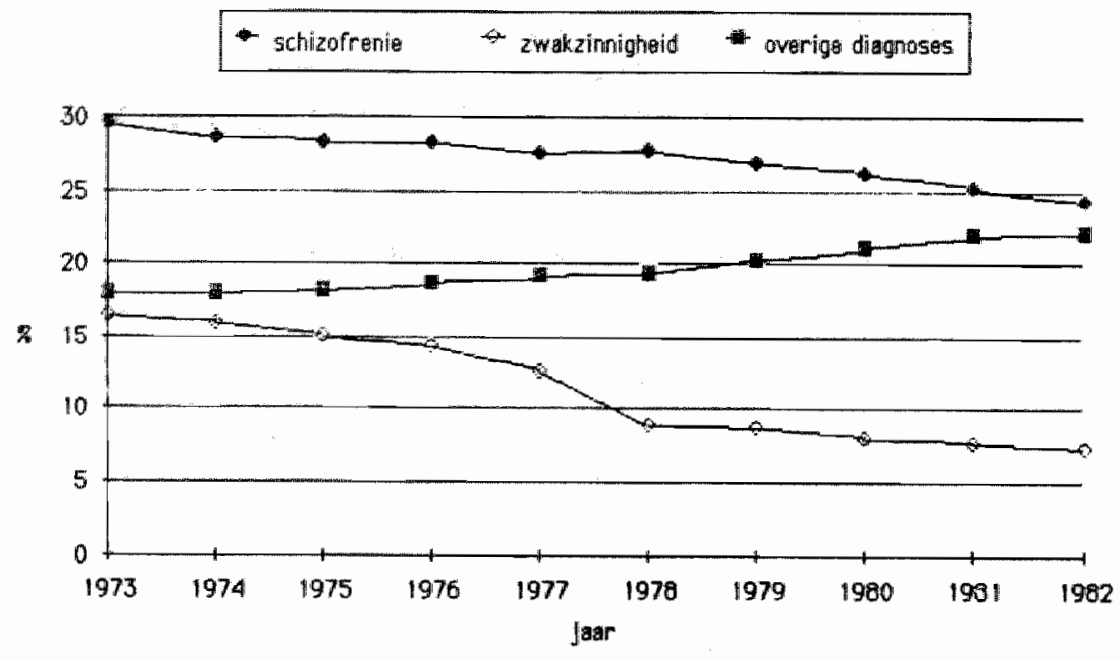

Schizofrenle was, en is nog steeds, de meest voorkomende psychiatrische diagnose. Op bijna de helft van de langverblijvende mannen en meer dar éénderde van de vrouwen was in 1982 deze diagnose van toepassing. De diagnose "zwakzinnigheid" kwam in dat jaar veel minder voor (78) dan 10 jaar eerder (16\%). Met name de grotere mortaliteit, mar tevens de overplaatsing van deze patiënten naar apart erkende afdelingen, zwakzinnigeninrichtingen en gezinsvervangende tehuizen hadden een wezenlijk effect op de werbliffsuurcijers van psychiatrische ziekenhuizen (Haveman, $1984)$.

De daling van het a antal 1.0.p. In psychiatrische ziekenhuizen kan dus voor een groot deel worden toegeschreven an de vermindering van het aantal zwakzinnigen; - bij de vrouwen tevens door een vermindering van het antal schizofrene patiënten (Haveman, 1981).

De bijdrage van andere diagnostische groepen aan het bestand van 1.0.p. nam zowel bij de mannen als de vrouwen vanaf 1978 weer toe. Door de toename van deze diagnostische groepen binnen het 
totale bestand van $1.0 . p$. werd vanaf 1978 het effect van de afname van het aantal zwakzinnigen en schizofrene patiènten voor een deel gecompenseerd.

Het is moeilijk om aan de hand van deze gegevens van de patiëntenregistratie van de Geneeskundige Hoofdinspectie voor de Geestelijke Volksgezondheid (GHIGV) te beoordelen in hoeverre deze veranderingen qua diagnostiek verklaard kunnen worden door :

(a) werkelijke veranderingen in de samenstelling van het longstay bestand, bijv. minder zwakzinnigen

(b) veranderingen in het stellen van een diagnose, bijv. voorzichtiger hanteren van de diagnose "schizofrenie" (niet affectieve psychosel en het vermelden van "zwakzinnigheid" als nevendiagnose $i \cdot p \cdot v$. hoofddiagnose, en

(c) een in 1978 gewijzigd registratiesysteem, aan de hand warvan de diagnosen van de bestandspatiënten werden geactualiseera.

Schema 6: Het aandeel lang opgenomen patiẻnten in algemene psychiatrische ziekenhuizen op 31 december $1973 \mathrm{t} / \mathrm{m} \mathrm{1982}$; narar leeftijd.

- 45 jaar $\quad 55-64$ jaar $\quad 65$ jaar an ouder

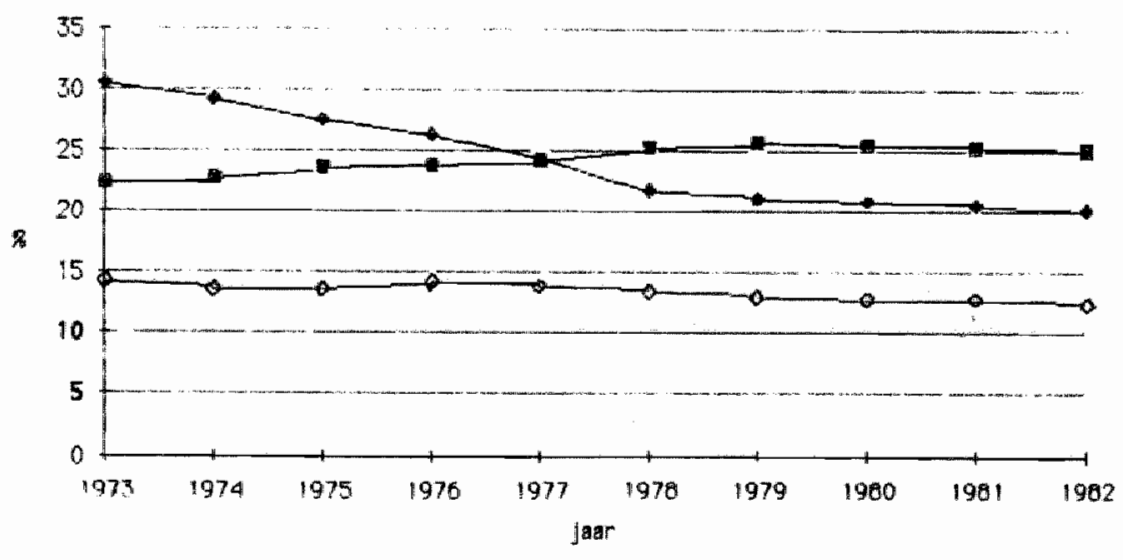


Opvallend waren ook de veranderingen die zijn opgetreden in de leetujdsverdeling. Doordat het aandeel patiênten van jonger dan 55 jaar fors terugliep (mede veroorzaakt door sterfte en overplatsing van aiep zwakzinnigen), bepalen vandaag de bejaarde patiänten het beeld in de long-stay sector. Dit geldt zowel voor de mannen war het aandeel bejaarden binnen het totaal van lang opgemonen patiêten toenam van 27 in 1973 tot 348 in 1982, maar meer nog voor de vrouwen. Zo is in een periode van 10 jaar het aandeel bejaarde vrouwen in het long-stay bestand gestegen var 398 in 1973 tot 528 in 1982 .

\subsection{Lang opgenomen patiënten in psychiatrische dagziekenhuizen}

Het begrip "psychiatrisch dagziekenhuis" is enigszins verwarrend. Meer dan de helft van de "dagziekenhuis"-patiënten van ons onderzoek werden niet begeleid en behandeld in een ruimtelijk gescheiden gebouw op of buiten het instellingsterrein van een psychiatrisch ziekenhuls, maar volgden overdag therapie- en activiteitenprogramma's samen met patiënten die het gehele etmaal in het psychiatrisch ziekenhuis verbieven. Het gaat daarbiji om een combinatie van (activiteiten-) therapieên gericht op gedragsverandering, resocialisatie en reactivering gedurende tenminste vier en maximal acht uur per dag. Deze situatie wordt beter getypeerd door de verstrekkingenterm "dagbehandeling c.q. deeltijdbehandeling" dan door het erkenningenbegrip "psychiatrisch dagziekenhuis".

De functie "deeltijdbehandeling overdag" wordt voor vroeger lang opgenomen patiënten vervuld door ongeveer éénderde van de algemene psychiatrische ziekenhuizen. Er werden gedurende het onderzoek geen aanwifzingen gevonden dat de dagziekenhuizen van psychiatrische afdelingen van algemene ziekenhuizen, van universiteitskilinieken en de zelfstandig functionerende dagziekenhuizen, een wezenlijke bijdrage leveren an de begeleiding van lang opgenomen patiénten. 
Voor psychlatrische dagbehandeling komen, volgens het verstrekkingenbesluit Ziekenfondswet (1973), patienten in aanmerking die voor deze behandeling redelijkerwijs zijn aangewezen en die in staat zijn, althans een deel van het etmal, zelfstandig in de matschappij te verblijven en voor wie het verkrijgen van volledige zelfstandigheid is te verwachten (1). Vooral de laatste passage, de prognose van valledige zelfstandigheid, heeft bij het begin van het onderzoek geleld tot de aanname dat psychiatrische dagbehandeling slechts tijdelijk is en beperkt blijft tot een groep patiēnten met goede sociale varaigheden en eigen huisvesting (zelfstandig, gastgezin, pension en dergelijke).

Later bleek dat het "tijdelijke" karaktex van psychiatrische dagbehandeling een zeer rekbaar begrip is voor patienten die langdurig klinisch opgenomen waren geweest (Haveman, Poelijoe, Tan, 1986). Zo stond bijna de helft (49: van de doelgroeppatiënten langer dan één jaar voor psychiatrische aagbehandeling ingeschreven, waarvan $19 \%$ zelfs langer dan vijef jaar. Ook de prognose van de psychiater over ontslag uit dagbehandeling wees niet op een snel verloop in de nabije toekomst. Van $13 \%$ van de patiěnten werd verwacht dat $z i j$ in een perlode van zes maanden ontslagen zouden worden en $33 \%$ eventueel, terwijl $50 \%$ volgens de prognose langer dan zes manden onder behandeling zou blijven.

Voor een groot aantal van deze patiënten lijkt dus de dagbehandeling het meest halbare te zijn, bij behoud van zelfstandige huisvesting. Deze situatie is beter te omschrijven met het begrip "dagzorg" dan met de term "dagbehandeling". Het begrip "zorg" sluit voor deze groep van patiënten beter aan bij de lintenties, de activiteiten en de perilode van de begeleiding.

(1) Voor de voetnoten wordt verwezen naar pagina 237 . 


\subsection{Lang opgenomen patiënten in beschermende woonvormen}

Het meest opvallende an de sector van de beschermende woonvormen is de variatiebreedte. Er zijn grote beschermende woonvormen met meer dan 100 bewoners, mat ook kleine met vier bewomers. Sommige instellingen hebben vooral oudere, andere wederom vooral jonge bewoners. Enkele instellingen hebben een grote doorstroming, de meeste instellingen zijn echter vooral residentiële voorzieningen voor onbeperkte duur. Zij bieden soms zelf op gedragsverandering gerichte programma's aan, maar geven vooral ondersteunende hulp en stimuleren het gebruik van WSW-instelingen. zij zijn soms goed geintegreerd in de sociaal-psychiatrische hulpverlening. mar ex zijn ook instelingen die nauwelijks contacten hebben met Riagg's.

In het eindrapport van de Interdepartementale Werkgroep Beschermende Woonvormen (1981) werd een poging ondernomen om binnen deze diversiteit van instelingen twee typen woonvormen te onderscheiden, namelijk het hostel en het pensiontehuis. zij zouden onderling verschillen in de mate van geboden begeleiding en de duur van het verblijf van de bewoner.

De doelstelling van een hostel was geformuleerd als: het bieden van sociaal-psychllatrische behandeling, beschermende huisvesting, woonrevalidatie en begeleiding aan die mensen met psychische stoornissen van wile verwacht wordt dat zij ulterlijk na 2 jaar naar een zelfstandige woonvorm kunnen verhuizen. Van het hostel wordt dus, evenals van psychiatrische dagbehandeling, verwacht onder andere een brugfunctie te verwulien tussen klinisch-psychiatrische behandeling en zelfstandig wonen in de matschappij. Een hostel wordt geacht een doorstroominsteliing te $z i j n$ en geen residentiè le eindvoorziening.

Ten aanzien van het pensiontehuis werden in het rapport geen grenzen gesteld aan de duur van het verblijf. De doelstelling werd als volgt geformuleerd: het bleden van begeleiding, beschermende huisvesting en woonrevalidatie aan mensen die door psychische factoren - tijdelijk of blijwend - niet in staat zijn tot 
zelfstandig wonen in de matschappij en die bij het ontbreken van deze voorziening zijn aangewezen op opname in een psychỉtrisch hostel of psychiatrisch ziekenhuis. In deze visie kon een pensiontehuis de functie van residentielle eindvoorziening vervullen. onder de voorwarde dat de bescherming en ondersteuning gedurende de periode van verblijf noodzakelijk is en meer zelfstandige huisvesting niet mogelijk. Tot zover de in het eindrapport van de Interdepartementale werkgroep verwoorde visie.

Bescherma wonen betekent in de praktijk vooral langdurig beschermd wonen. Instellingen met een grote doorstroming zijn schaars. Uit een landelijk ondermoek bleek dat in driekwart (778) van de beschermende woonvormen meer dan de helft van de beworers langer dan twee jaar woonden (Haveman, 1982a). De meeste instellingen hadden dus zowel langdurig als kortdurig wonenden, en waren geenszins de ideal-typische doorstroom- of langverblijfhuizen van het IWBW-rapport.

In het eindrapport van de GHIGV-werkgroep beschermende woonvormen (1983) wordt de scheiding tussen hostel en pensiontehuis als onwerkbaar van de hand gewezen. Deze schelding zou haaks staan op het streven naar flexibiliteit en diversiteit, en niet stroken met de praktijk. Zowel in het definitieve regeringsstandpunt ten aanzien van het IWBW-rapport (1984) als het Besluit ziekenfondsraad Beschermende Woonvormen (1985) worden hostels en pensiontehuizen dan ook niet meer onderscheiden en niet meer van aparte indicatiecriteria voorzien. Wel wordt gepleit voor het instellen van indicatlecommisies voor Regionale Instellingen voor Beschermende Woonvormen (RIBW).

De doelstelingen en functies van beschermende woonvormen zijn in de huidige situatie weinig concreet en hanteerbaar ombchreven. Het probleem van de doelgroepomschrijving voor deze voorzieningen lijkt verschoven te zijn van de overheid nar de regionale indicatiecommissies. 

DEEL II - VRAAGSTELLING EN OPZET VAN HET ONDERZOEK

\section{Vraagstelling}

Zowel de omvang van de groep lang opgenomen patiënten in psychiatrische ziekenhuizen (hfast. 3), als ook hun geringe kans bij ongewijzigd beleid op vervangende zorg, was de anleiding om de volgende vraag in dit onderzoek centraal te stellen:

Welke factoren belemmeren $c . q$. bevorderen het ontslag naar vervangende zorg van lang opgenomen patiënten uit psychiatrische ziekenhuizen?

Deze vraagstelling bevat begrippen als lang opgenomen patienten (4.1.), psychiatrische ziekenhuizen (4.2.), ontslag naar vervangende zorg (4.3.), en ontslagbelemmerende factoren (4.4.) die nadere toelichting behoeven.

\subsection{Lang opgenomen patiënten.}

Over het "point of no return", het tijdstip waarop een periode van opname min of meer definitief wordt, zijn hulpverleners, onderzoekexs en beleidsmakers het weinig met elkaar eens. "Als men de grenzen ruim stelt", schrijft offerhaus (1983), "kan men zeggen dat ergens tussen de drie en vierentwintig maanden inrichtingsverblijf de persoon zo vervormd is dat de kans op terugkeer naar de eigen omgeving vrijwel nihil is geworden. Alle aandacht dient er dus op gericht te zijn te voorkomen dat deze termijn wordt overschreden" .

Deze visie lijkt te pessimistisch bij analyse van gegevens van de Patiëntenregistratie Intramurale Geestelijke Gezondheidazorg (PIGG) van de Geneeskundige Hoofdinspectie voor de Gerstelijke Volksgezonaheid (GHIGV, 1984). Uit deze registratie blijkt dat ook van de patiènten die 2-5 jaar continu in een prychiatrisch ziekenhuis verbleven, in 1982 nog 10 s naar de eigen ongeving werd ontslagen. De helft daarvan ging alleen wonen, de andere helft ging bij anderen inwonen (ouderlijk huis, eigen gezin, 
familie/kennissen, pleeggezin, gastgezin, samenwonend, begeleide Kamerbewoning, pension/-kosthuis). Voor de patiẻnten met een werblijfsduur van 5 tot 10 jaar en 10 jaar en langer was het aandeel patiënten dat nax de eigen ongeving werd ontslagen kleiner met $3 \%$ respectievelijk $2 \%$. Dus ook na een opnameperiode wan 10 jaar komen nog steeds enkele patienten in aamerking woor zelfstandige of beschermale huisvesting buiten de instelling. De keuze van het verblijfsduureriterium van twee jaar of langer woor Thet selecteren van lang opgenomen patiënten is dan ook erigszins arbitrair.

Het onderhavige onderzoek werd toegespitst op patiënten uit de volgende drie verblijfsduurgroepen in algemene psychiatrische ziekenhuizen:

1) zeer lang opgenomen patiënten $(z \cdot 1.0 \cdot \mathrm{p}$.$) : patiënten die langer$ dan 5 jaar continu in een a.p.z. verblijven;

2) lang opgenomen patiënten, continu $(1.0 \cdot p \cdot-c)$ : patiënten die tussen de 2 en 5 jaar continu in een a.p.z. verblijven;

3) lang opgenomen patiênten, discontinu (1.0.p.-dc): patiënten die in de 5 jaar voorafgand aan dit onderzoek over 2 of meer opnames in een psychilatrisch ziekenhuis of paaz een cumulatieve verblijfsduur van minimal 30 manden hebben opgebouwa.

Daarnaast werd de groep patiënten van psychiatrische ziekenhuizen vergeleken met een tweetal referentiegroepen, namelijk met personen die op het moment van het onderzoek in beschermende woonvormen of psychiatrische dagbehandeling verbleven, maar daarvoor lang in een algemeen psychiatrisch ziekenhuis waren opgenomen. ook deze referentiegroepen werden nar de arie verblijfsduurgroepen onderacheiden.

Perconen met de diagnose "seniele dementie" en "mentale retardatie" zijn zowel bulten de onderzoeksgroep als de referentiegroep gelaten. De verblijfsduurgroepen 1 en 2 worden ook wel eens aangeduid als "old long-stay" en "new long-stay". Deze begrippen zullen in het vervolg worden vermeden daar "old long-stay" niet moodzakelijkerwijs "bejaarde patiënten" of een "oud" opname- en 
ontslag beleid van instellingen (b.v. van de 50-er en 60-er jaren) betekent, en ook "new long-stay" in princlpe de laatste van vele (langdurige) opnames kan zijn.

Nast de patiẻnten die langaurig en continu zijn opgenomen, warden door Schipper (1978) ook de frequent maar even langdurig opgenomen patiënten tot de chronische patiënten van psychilatrische ziekenhuizen gerekend. Over de omvang, samensteliing en kenmerken van deze patiënten (1.a.p.-dc.) is weinig bekend, afgezien van enkele cijfers uit de PIGG-registratie (Brook, 1984: Haveman, 1980 a bl.

\subsection{Psychiatrische ziekenhuizen}

Het onderzoek beperkte zilch tot de door het Ministerie van Wvc erkende algemene psychiatrische ziekenhuizen (Ministerie WVC, $1983 \mathrm{~b})$ met uitzondering van twee instellingen die na $1980 \mathrm{zijn}$ opgericht, en vier instellingen die zich min of meer hebben gespecialiseerd op bepaalde groepen patiënten. Van de overblijvende 38 algemene psychiatrische ziekenhuizen (a.p.z.) hebben er vijf deelgenomen aan dit onderzoek (zie verder hfdst. 10.1.).

\subsection{Ontslag naar vervangende zorg}

Met ontslag naar vervangende zorg wordt bij de verdere verslaglegging bedoeld: een mogelijke of daadwerkelijke platsing voor huisvesting en begeleiding van 1.0.p* buiten het terrein van een psychiatrisch ziekenhuis, of op het terrein van een psychiatrisch ziekenhuis als het gat om een vorm van kleinschalig wonen fsociowoning).

Het onderzoek richtte $z$ ich vooral op vervangende zorg voor 1.0.p. door beschermende woonwormen en voorzieningen voor psychiatrische dagbehandeling. Daarnaast is tevens aan hulpverleners in psychiatrische ziekenhuizen een oordeel gevraagd over het in aanmerking komen van $1.0 \cdot \mathrm{p}$. voor: 
- zelfstandige kamerbewoning (zonder en met begeleiding vanuit Riagg of polikiniek);

- flat-/huibbewoning met andere ex-patienten (zonder en met begelleiding vamuit Riagg of polikliniek);

- beschermd samenwonen onder personele begeleiding in een woonhuis op het terrein van een psychiatrisch ziekenhuis (sociowoningen):

- psychiatrisch hostel/sluisinternat (intensieve op ontslag gerichte behandeling in een kleinschalige voorziening).

Een andere vorm van vervangende zorg, namelijk psychiatrische gezinsverpleging bleef in dit onderzoek buiten beschouwing daar slechts enkele psychiatrische ziekenhuizen (Beileroord, Dennenoord, St. Joseph Stichting, Vijverdal, P.C. Venray) voldoende ervaring hebben met deze zorgvorm.

\subsection{Onts lagbelemmerende c.g. -bevorderende factoren}

Het selecteren van de variabelen op relevantie voor de vraagstelling was niet eenvoudig. Zo wordt in de vakliteratuur een breed scala van factoren in verband gebracht met vertraging, luitstel en zelfs afstel van ontslag van patiënten uit psychiatrische ziekenhulzen. Een beargumenteerde selectie van onafhankelijke variabelen was dus noodzakelijlk, waarbij gekozen werd binnen de volgende clusters van factoren:

1) patiëntfactoren

2) afdelings- en instelingsfactoren

3) gezins- en hulsvestingsfactoren.

In hoofdstuk $6 \mathrm{zal}$ in verband met de afgeleide vraagstellingen worden aangegeven, warom in dit onderzoek voor bepalde variabelen werd gekozen.

\section{Onderzoeksplen}

Vanuit een theoretisch perspectief is het boeiend om naar oorzaken te zoeken, warom bepaalde patiënten wel en andere weer niet langaurig in een psychiatrisch ziekenhuis blijven opgenomen. De 
analyse is dan gericht op factoren die in het verlleden hebben gespeeld en geleid hebben tot langdurige opname. Een eerste optie voor dergelijk onderzoek is bijvoorbeeld het volgen van processen, het bestuderen van onderhandeling en besluitworming tussen actoren (patiënt, familieleden, plaatsende instantie, afdelingsarts e.d.), die tot een kort of langaurig verblijf van een patiënt in een psychiatrisch ziekenhuis hebben geleid.

Ander verklarend onderzoek met betrekking tot chroniciteit en long-stay is niet proces- mar aspectgericht. Ieder aspect heeft weer een min of meer uitgebreide onderzoekstraditie. Het antal aspecten is groot en uiteenlopend van aard, waarbij soms het ene, soms weer het andere aspect de belangrijke onathankelijke variabele in het onderzoek is. De volgende aspecten (clusters van variabelen) in dergelijk verklarend onderzoek kunnen worden onderscheiden:

- persoonlijkheidsstructuur (premorbide factoren: stressgevoeligheid; afhankelijkheid en passiviteit)

- aard en beloop van de psychische stoornis (psychiatrische diagnose en prognose)

- ernst van het probleem voor het functioneren van betrokkene (primaire handicaps)

- belasting en gevaar voor anderen

- structuur, kenmerken en houding van het natuurlijk milieu (als etiologische factor binnen het gezin, maar tevens in de betekenis van weinig steun en hulp, en uitstoting)

- gebrekkige extramurale professionele hulpverlening aan betrokkene en gezin/familie

- gebrek aan plaatsen in "tussenvoorzieningen" (b.v. crisisinterventiecentra, psychiatrische hostels en dagziekenhuizen)

- weinig intensieve of weinig doeltreffende intramurale behandeling

- interne organisatie van het algemeen psychlatrisch ziekenhuis (instellingsfactoren)

- iatrogeme effecten van langdurige opname (afdelingsfactoren, secundaire handicaps) 
- gebrekkige motivatie bij de patient tot ontslag

- gebrek aan geschikte plaatsen in woonvoorzieningen (b.v. pensiontehuizen) en dagcentra

- weinig samenwerking tussen voorzieningen, wardoor doorstroming naar instelingen buiten het $a \cdot p \cdot z$. wordt belemmerd.

Bovengenoemd onderzoek naar de oorzaken voor een lang klinisch verbliff of nat de oorzaken voor gestoorde wardigheden van lang opgenomen patiênten hebben een betrekkelijk lange onderzoekstraditie. Maar de kernvraag die een kwart eeuw geleden werd gesteld, namelijk of de tekorten van vaardigheden van lang opgenomen patiênten zijn toe te schrijven aan patient-externe factoren zoals de zorg in het ziekerhuis (Wing Brown, 1961) of inherent zijn alan het ziekteproces, is nog steeds een punt van discussie en verkeert in een renaissance van aandacht, zoals blijkt uit meer recente publicaties (Johnstone e.a., 1981; Lamb, 1982; Ciompi, 1980; Mathai \& Gopinath, 1986).

In dit onderzoek waren wij minder geinteresseerd in de oorzaken van bijvoorbeeld gestoorde vaardigheden. De vardigheden van de patiënt werden niet beschouwd als afhankelijke variabelen, maar behoorden tot de te bestuderen onafhankelijke variabelen in verband met de indicatiestelling van patiënten voor vervangende zorg.

Vanuit deze invalshoek was het belangrijk on de actuele toestand te beschrijven, waarin een langdurig opgenomen patiënt verkeerde voor een aantal relevante aspecten, met als vragen:

- over welke vaardigheden beschikt de patiënt;

- wat is de nu geldende diagnose:

- is er sprake van agressief of sulcidaal gedrag e.d. om vervolgens dergelijke (onafhankelijke) variabelen te koppelen aan het oordeel van hulpverleners over vervangende zorg (afhankelijke variabele). Deze beperkte doelstelling vormale het uitgangspunt voor het onderzoek, waarbij met een transversaal design kon worden volstaan. 
5.1. Normering van de afhankelijke variabele: mogelijkheid van vervangende zorg

Er zijn verschillende mogelijkheden om de normering, namelijk het oordeel welke patiënt wel en welke niet voor vervangende zorg in aanmerking komt, niet aan de onderzoeker over te laten, mar te koppelen aan referentiepunten buiten de positie van de onderzoeker.

\subsubsection{Directe normering}

Bij directe normering bepalen deskundigen welke patiënten wel en welke niet voor ontslag in aanmerking komen. Voorbeelden van methoden voor directe normering via panels van deskundigen zijn de Dellphi-methoden, de nominale groep techniek, Glaser's "state of the art"-methode of een $\mathrm{zgn}$. "conference development"-methode (Brorsson \& Wal1, 1985).

De panel benadering(2) heeft een aantal nadelen, namelijk het gevaar van:

- conservatisme (de tendens om van bestaande instellingen en het vigerende intakebeleid uit te gaan):

- gedeeltelijke normering door onderzoekers (de onderzoekers zullen een oplossing moeten vinden, hoe zij met minderheidsstandpunten in panels omgaan):

- de mate van abstractie (veelal wordt het oordeel van panelleden niet gevraagd naar aanleiding van een concrete steekproef van instellingen en patienten); daarmee samenhangend:

- de validiteit van beoordeling (niet ieder panelidd gaat van dezelfide patiënten en voorzieningen ult);

- het beoordelen van singuliere factoren (terwijl de werkelijke opname-indicatie stoelt op een veelvoud van variabelen die onderling gewogen en per individu verschillend tot een besluit van platsing leiden); 
- de representativiteit van de panelleden lom practische en financiele redenen wordt veelal niet een aselecte steekproef getrokken van voldoende onvang uit het "universum van deskundige hulpwerleners");

- de belangen van panelleden bij substitutiekwestiea (dit aspect kan met name van belang zijn als directie- en bestuursleden van instellingen in het panel zitting hebben):

- de a-specifleke sociaal-psychologische processen binnen het panel (niet alleen inhoudelijke discussie en argumentatie bepalen de besluitvorming, maar tevens aspecten als b.u. macht, aanzien, verbaal vermogen en coalitievorming van panelleden).

B1j substitutie-onderzoek wordt weI eens gewerkt met een andere vorm van directe normering, namelijk zogenaamde bezoekteams. Dat zijn breed samengestelde commisies van deskundigen die op een min of meer gestandaardiseerde manier een representatieve steekproef van patiënten (of de totale populatie) beoordelen op mogelijkheden voor ontslag of owerplaatsing naar andere voorzieningen.

Een voorbeeld van een dergelijke benadexing vormt het onderzoek van Mann en Cree (1976). Hun doelstelling was na te gaan wat de redenen waren voor de toename van het aantal nieuwe langblijvers in psychiatrische ziekenhuizen. Tevens vroeger zijzich af of deze klinisch opgenomen patiênten even goed of beter door andere instellingen of instanties opgevangen konden worden. Het onderzoek had betrekking op patiënten met een verblijfsduur van $1-3$ jaar en een leeftijd bij opname van 15 tot 65 jaar. Uit iedere Regional. Hospltal Board Area in Engeland en Wales, werd at random éen ziekenhuis met meer dan 500 bedden gekozen, in het geheel dus 15 instellingen. Binnen iedere instelling werd weer at random een steekproef van 25-30 patienten getrokken die aan het leeftijasen verbliffsduurcriterium roldeden.

Een bezoekteam, samengesteld uit een psychiater en een sociaalpsychiatrisch verpleegkundige, had voor ledere instelling twee waken de tija om zoveel mogelijk informatie over de desbetref- 
fende patiënten te verzamelen. Getracht wera met behulp van deze informatie de patienten naar zeer verschillende vormen van vervangende zorg in te delen nar mate van ambulantie en bescherming, namelijk van zelfstandig wonen tot en met 24-uurs klinische zorg.

Onafhankelijk van de taxaties van het bezoekteam, werden de patiënten op basis van de verzamelde gegevens nogmaals in de groepen ingedeeld door een tweede onderzoeksteam bestaande uit een psychiater en een sociale wetenschapper. Ook a an de behandelaars (psychiater en verpleegkundigen) werd per patiënt een taxatie gevraagd van ontslagmogelijkheden.

In dit onderzoek werd dus voor de normering van ontslagmogelijkheden gebruik gemakt van oordelen van drie soorten "panels", namelijk bezoekteam, externe deskundigen en behandelaars. Tenslotte is nagegaan op welke kenmerken de patiënten van de 10 groepen verschilden, uitgaande van de indeling c.q. normering door het bezoekteam.

Bij deze benadering vervalt een groot aantal bezwaren van het normeren met behulp van panels. Maar niet alle problemen zijn door het hanteren van deze methode opgelost. Punten als representativiteit van, belangen en a-specifieke sociaal-psychologische processen binnen bezoekteams kunnen ook hier de uitkomaten vertekenen.

Een groot voordeel is de toepasbaarheld van de resultaten. De lijn van onderzoek naar beleid is zeer direct, doordat eventueel beslissingen op patiëntnivveau kunnen worden genomen. Mar dat is sterk afhankelijk van de status en bewoegdheden van de bezoekteams.

Soms wordt vanuit ethische overwegingen gepleit voor adviserende of uitvoerende bevoegdheden van bezoekteams, soms daartegen. De Haen en Schretlen (1981) stellen in dit verband de vraag ".. of je het psychiatrische patiënten kunt andoen hen te laten screenen door voor hen onbekende deskundigen, terwijl ze van een dergelijke screening persoonlijk niets te verwachten hebben". Deze vraag is te eenzijaig gesteld. Voor sormige patiënten mag 
gelden dat het praten over andere opvangmogelijkheden gepaard gat met gevoliens van hoop en positieve verwachting. Anderen zullen hopen dat het bij praten biljft. zij vrezen het onbekende en nieuwe, en zullen bij werkelijke veranderingen met een "resistance to change"-houding reageren, of - zoals elders beschreven met een vlucht in de psychopathologie. Goffman (1961) heeft de onderliggende attitude ooit eens amschreven als de vrees van "... moving from the top of a small world to the bottom of a large one".

Een belangrijk nadeel van de methode van bezoekteams zijn tevens de kosten. Deskundigen zijn in de regel duur, en zowel de gegevensverzameling zelf als de evaluatie per patiênt is tijarovend en personeelsintensief. Zo zijn interviews met hulpverleners en patienten nodig, eventueel aangevuld met informatie uit dossieronderzoek.

Een andere mogelijkheid van directe normering is om uit te gaan van het oordeel van het afdelingspersoneel bij een representatieve steekproef van patiënten. In ons onderzoek is voor deze benadering gekozen. In hoofdstuk 5.2. zal deze keuze worden beargumenteerd en de onderzoeksopzet nader beschreven.

\subsubsection{Indirecte normering}

Nast deze methodieken van directe normering, waar het oordeel van deskundigen centraal staat, zijn er ook indirecte methoden om referentiepunten te bepalen. Bijvoorbeeld door de intake-criteria en kenmerken van bewoners van enkele modelvoorzieningen, $b . v$. semimurale voorzieningen met relatief veel ex-1.0.p. en een veelbelovend zorgconcept, te vergelijken met potentiële doelgroeppatiènten in algemene psychiatrische ziekenhuizen (a.p.z.). Een andere mogelijkheid is om niet alleen personen van enkele modelvoorzieningen mar alle personen die na een langdurige opname in een $a \cdot p \cdot z$. nu in een alternatieve setting verblijven (bijvoorbeeld beschermende woonvorm of psychiatrische dagbehandeling) als referentiegroep te beschouwen. De veronderstelling 
daarbij is dat personen in psychiatrische ziekenhuizen die aan de kenmerken van de referentiegroep voldoen, ook naar dergelijke voorzleningen ontslagen kunnen worden.

In het voorliggende onderzoek $z_{1 j n}$ de resultaten zoals verkregen door de directe normeringsmethode voor een antal variabelen nog eens getoetst aan de hand van de indirecte benadering.

\subsection{Design}

Bij het beoordelen van ontslag- en overplaatsingsmogelijkheden door afdelingspersoneel kan terecht worden gewezen op eventuele vertekening door belangenkwesties (pleiten voor ontslag betekent opheffen van arbeidsplaatsen) en conservatisme (oordelen vanuit de huidige situatie). Er wordt veel gesproken over zorgafhankelijke patiênten, mar ook de hulpverleners kunnen voor de zorgverlening op de afdeling afhankelijk zijn van enkele patienten die het klimat op de afdeling in gunstige zin beinvloeden. Pleiten voor ontslag vam deze patiênten zou het gevonden evenwicht op de afdeling in gevaar kunnen brengen.

Intramurale hulpverleners blijken tevens minder dan ambulante en semimurale hulpverleners vertrouwen te hebben in de opvangmogelijkheden van beschermende woonvormen, bijvoorbeeld in de vorm van psychiatrische hostels. De resultaten van het onderzoek van De Haen \& Schretlen (1981) maken het aannemelijk dat door intramurale beoordelaars hogere drempels voor ontalag en substitutie worden gehanteerd, door meer en scherpere ontslagcriteria. De keuze voor personeel van afdelingen voor het beoordelen van substitutiemogelijkheden biedt echter ook voordelen. zo zijn verpleegkundigen, afclelingspsychiaters, -psychologen e.d. in de regel veel beter geinformeerd over de voorgeschiedenis en leefgituatie van de patiènt dan panelleden en bezoekteams, hoe serieus externe beoordelaars ook hun taak opvatten.

Een ander voordeel is dat het redelijk realistische schattingen betreft. Bij een panelbenadering wordt gedaan, alsof het ontslag van patiënten extern, b.v. door middel van protocollen, kan worden geregeld. Afdelingen van a.p.z.-en zijn echter betrekke- 
lijk autonoom in hun ontslagbeleid. Tussen het paneloordeel en daadwerkelijke substitutie ligt het krachtenveld van meningen van de patiẻnt zelf. Familieleden en het afdelingspersoneel. Het lijkt van belang om hierin meer inzicht te krijgen. Bij de patiênt dient dan naar de wens tot ontslag gevraagd te worden, aan de verpleegkundige en nog eens apart aan de psychiater/psycholoog naar de mogelijkheden van ontslag. Dat de resultaten op kortere termijn beschikbaar komen en het onderzoek minder kostbaar is, zijn bijkomende voordelen.

In dit onderzoek werd bij een aselecte steekproef van lang opgenomen patiënten in a.p.z.-en zowel aan een verpleegkundige als een psychiater/psycholoog de volgende vraag gesteld: "Komt betrokkene volgens 0 , gezien zijn/haar huidige functioneren, in aanmerking voor ....", - waarna vervolgens een reeks van mogelijke voorzleningen werd genoemd. Het waren ldentieke items in de Vxagenlijst onderzoek Long-stay I (VOL I : psychiater/psycholoog) en de Vragenlijst onderzoek Long-stay II (VOL II: verpleegkundige/mentor). De hulpverleners werden verzocht de vragenlijsten onathankelijk van elkaar in te vullen.

Per patiënt kon zodoende een tweetal oordelen worden verkregen over mogelijkheden van:

a) zelfstandige kamerbewoning zonder begeleiding vanuit Riagg of polikliniek ;

b) zelfstandige kamerbewoning met begeleiding vanuit Riagg of polikliniek ;

c) flat-/huisbewoning met andere ex-patiëntem zonder begeleiding vanuit Riagg of polikliniek:

d) Elat-/hulsbewoning met andere ex-patienten warbij begeleiding vanuit Riagg of poliklinlek is geregeld;

e) bescherma samenwomen onder personele begeleiding in een woonhuis op het terrein van een psychiatrisch ziekenhuis;

f) bescherma samenwonen onder personele begeleiding buiten het terrein van een psychiatrisch ziekenhuis;

g) psychiatrisch hostel/sluisinternat (intensieve op ontslag gerichte behandeling in een kleinschalige voorziening);

h) psychiatrisch dagziekenhuis ('s nachts bij familie/gezin);

i) psychiatrisch dagziekenhuis (in combinatie met $a, b, c$ of d). 
Elke vraag kon met ja, misschien of nee worden beantwoord. Vervolgens werden twee groepen patiënten onderscheiden.

1) patiënten warbij belde hulpverleners, psychiater en verpleegkundige, voor tenminste ến en dezelfae voorziening (a $t / m$ i) plaatsingsmogelijkheden aangaven,

2) patienten waarbij slechts én van de hulpverleners plaatsingsmogelijkheden zag, beiden twijfelden (misschien), of belden geen alternatieve opvang mogelijk achtten (a $t / \mathrm{m} i)$.

Schema 7 is een grafische representatie van het in dit onderzoek beoogde overeenstemmingsoordeel van psychiater en verpleegkundige.

Schema 7: Het criterium voor overeensteming tussen psychiater en verpleegkundige over de mogelijkheid van vervangende zorg.

psychiater

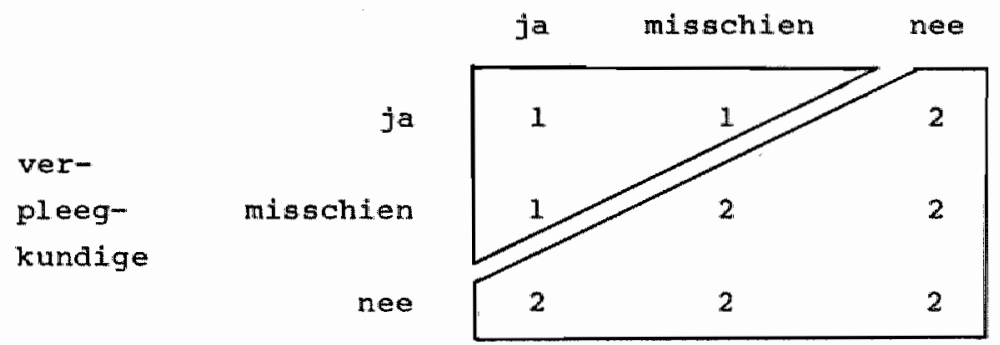

De eerste groep, de vervangende zorg-groep, bestond ult al die patiënten, waarin psychiater en verpleegkundige overeenstemden dat een concrete plaatsingsmogelijkheld aanwezig was. Als criterium voor overeenstemuing gold dat een "ja" van de ene beoordelaar tenminste moest corresponderen met een "misschien" van de andere beoordelaar. Deze groep is in het schema aangeduid met het cijer " 1 ". 
Wu is het magelljk dat patienten, waarbil volledige overeenstemring tussen psychiater en verpleegkundige bestaat (ja-ja), systematisch op een aantal kenmerken verschillen var patiënten die voldoen aan het (breder) gekozen overeenstemmingscriterium (ja-ja ja-misschien misschien-ja). De "ja-ja"-groep zou over de gehele linie varaiger kunnen zijn, jonger e.d..

Voor de toetsing van deze vooronderstelling werd de groep patiẻnten, warbij volledige overeenstemming bestond tussen psychiater en verpleegkundige (ja-ja), vergeleken op een 25-tal variabelen met de groep patiẻnten waarbij beperkte overeenstemming bestond (ja-misschien \& misschien-ja). Deze analyse is uitgevoerd voor patienten die in aammerking kwamen voor flat-/huisbewonjing met begeleiding vanuit Riagg of polikliniek, beschermd kleinschalig wonen in een woonhuis buiten het terrein of op het terrein van een psychlatrisch ziekenhuis. Voor de overige voorzieningensoorten waren te weinig warnemingen in één van beide subgroepen beschikbaar $(\mathbb{N}<9)$ voor een toetsing op verschillen op basis van de Fisher's exact test.

van de 75 kruistabellen ( 3 voorzieningensoorten $x 25$ variabelen) gaven twee tabelien significante verschilien te zien (3). Dar ook in absolute $z$ in de verschillen op bijvoorbeeld de vaardigheidsvariabelen niet groot waren, werd in het vervalg van het bredere overeenstemingscriterium (ja-ja \& ja-misschien \& misschien-ja) uitgegaan.

In hoofdstuk 11 zijn vervolgens de resultaten vermeld bij toepassing van dit criterium.

Daarnast werd gebruik gemakt van de methode van indirecte nomering aan de hand van referentiegroepen in psychiatrische dagziekenhuizen en beschermende woonvormen. Het ging om patiënten/bewoners die na een langdurig verblijf in een a.p.z. inmiddels in psychiatrische dagbehandeling of een beschermende woonvorm verbleven. Bij deze personen waren klaarblijkelijk tijdens het verblijf in het a.p.z. voldoende voorwarden a anwezig voor onts $1 \mathrm{ag}$.

Een belangrijk probleem bij deze benadering, namelijk de "time- 
lag", is nog niet genoemd. De referentiepersomen in psychiatrische dagziekenhuizen en beschermende woonvormen kunnen daar reeds lang verblijven. En het is onbekend, of de eventueel "betere" scores van de vergelijkingsgroepen tijdens het verblijf in deze voorzlening tot stand zijn gekomen, of reeds op het moment van overplatsing uit het a.p.z. bestonden.

Selectie vooraf met het criterlum van recent verblijf was niet mogelijk, ondat de operationalisering van "lang opgenomen patiënt" (1.0.p.) reeds een aanzienlijke beperking van de omvang van de doelgroep betekende. Bij de analyse van de gegevens werd dus van de enigsins arbitraire veronderstelling uitgegaan dat de beoordeelde kenmerken van de bewoners/patienten van psychiatrische dagziekenhuizen en beschermende woonvormen betrekkelijk constant bleven na intake.

ook was het voor de vergelijkbaarheid van de resultaten van bellang om variabelen, die bij patiënten van a.p.z.-en gemeten werden, op dezelfde wijze te meten bij de patiënten/bewoners van psychiatrische algziekenhuizen en beschermende woonvormen. Dit is zoveel mogelijk gebeurd in de vorm van geprecodeerde items in standaard-vragenlijsten voor de voorzieningen van de drie genoemde sectoren (hfdst. 7).

\section{Afgeleide vraagstellingen}

Bij het begin van het onderzoek was het selecteren van variabelen op relevantie voor de vraagstelling geen eenvoudige opgave. Zo werd een breed scala van factoren in verband gebracht met vertraging, uitstel en zelfs afstel van ontslag van patienten uit psychiatrische ziekenhulizen. Enige argumentatie en ordenling was dus nodig. Bij de bespreking van de varlabelen werd gekozen voor de volgende indeling:

1) patièntfactoren

2) afdelings- en instellingseactoren

3) gezins - en huisvestingsfactoren.

Hierna zal kort voor ledere categorie worden aangegeven waarom in dit onderzoek voor bepaalde variabelen werd gekozen. De aanwij- 
zinger uit de literatuur en het wooronderzoek werden zoveel mogelijk geformuleerd als te toetsen hypothesen binnen het onderzoek. Aan de keuze van de hypothesen ligt dus geen geëxpliciteerd theoretisch model ten grondslag. In navolgung vam Gadourek (1969) wordt met "hypothese" bedoeld: een vermoed antwoord op de gestelde vraag.

In hoofdstuk 7 wordt toegelicht hoe de gekozen variabelen werden geoperationaliseerd in de veagenlijsten.

\subsection{Patièntfactoren}

Het meeste onderzoek naar ontslagbelemmerende factoren voor lang opgenomen patienten is gericht op kenmerken bij de patiënt. Met name de volgende aspecten worden in verband gebracht met een ongunstige ontslagprognose: (1) het gebrek aan bepaalde vaaraigheden, (2) bepaalde psychiatrische diagnosen, (3) de aanwezigheid van geestelijke handicaps (mental retardation). (4) het gevaarscriterium, tegen zichzelf of anderen gerichte lichamelijke agressie, (5) een aantal demografische factoren, en (6) een negatieve attitude van betrokkene ten aanzien van ontalag.

\subsubsection{Vaardigheden}

Het belang dat wordt toegekend aan enerzijds de diagnose en symptomen van patiënten en anderzijds aan de persoonlijke vaardigheden en het sociaal functioneren, 1 ijkt in de psychiatrie mede afhankelijk te zijn van het tijdstip warop de patient onder de aandacht komt van de hulpverlener. Als de patiënt in het eerste stadium van zijn/haar problemen verkeert en bijvoorbeeld in een psychotische crisissituatle wordt opgenomen in een Paaz of psychiatrisch ziekenhuis, dan worden de beperkingen die betrokkene heeft in verband met zelfverzorging (wassen, kammen, kleden), het linnemen var voedsel, het omgaan met geld, mar ook in het vervulien van bepaalde sociale rollen als kostwinner, huisvrouw, student of buurman, direct gekoppeld an psychiatrische symptomen en een gestelde diagnose. Met andere woorden: de functiestoornis- 
sen, de beperkte vaardigheden en het verzaken van sociale verplichtingen worden als (tijdelijke) gevolgen beschouwd van de ziekte. Wing (1962) noemt dit de primaire handicaps.

Een dergelijke directe relatie tussen de ernst van psychiatrische symptomen en de beperkingen in vaardigheden en rolgedrag kon worden vastgesteld in de Groningse WHO-studie waarbij een cohort van patiënten met een eerste episode van een niet-affectieve psychose over een periode van drie jaar werd gevolgd (De Jong e.a.. 1983; Wiersma, 1983; Wiersma e.a., 1984; De Jong, 1984). In hun follow-up studies van jonge schizofrene patienten kwamen Strauss en Carpenter (1977). Isele en Angst (1985) en Test e.a. (1985) eveneens tot de conclusie dat met de ernst van de symptomen het social functioneren aanzienlijk werd beperkt. Wel wordt ten aanzien van acute schizofrene stoornissen er voor gewaarschuwd om te eenzijdig uit te gaan van een direct causaal verband tussen symptomen en sociale beperkingen. Brady (1984) wijst er op dat beide fenomenen elkaar kunnen beinvloeden in een circulair proces. De "a-sociale" symptomatische uitingen van schizofrenie kunnen de patiënt laten vervreemden van familie, vrienden en kennissen en beperkend werken op de sociale kansen van de patiënt. Tevens kan echter hun reactie van afwijzing en afzondering bij de patiènt leiden tot verdere vermindering van het gevoel van eigenwaarde en meer symptomatische uitingen van schizofrenie.

ondanks dergelijke kanttekeningen is het echter gebruikelijk om gestoorde vaardigheden van patiënten die voor de eerste keer worden opgenomen, te beschouwen als rand- of gevolgfenomenen Summers (1979) heeft het over "epifenomenen" - van symptomen. Dat wil overigens niet zeggen dat de beperkingen minder erg zouden zijn dan psychiatrische symptomen in de beleving var de patiënt, de familie en hulpverleners.

De activiteiten van psychiatrische rehabilitatie zullen voor deze groep patienten dan vooral gericht zijn op symptoombeheersing en -bestrijaing in de verwachting daarmee ook de vaardigheden en het saciale functioneren van de patiënt zoveel mogelijk in de oorspronkelljke staat te herstellen. Wiersma e.a. (1984) concludeer- 
den overigens op basis van follow-up gegevens dat deze verwachting bij schizofrene patiênten niet altija uitkomt. Ook als bij patiènten de symptomen tijdelijk of gedurende een langere perlode grotendeels zijn verdwenen, heeft een aantal patienten everveel beperkingen in hun sociale functioneren als voorheen.

In tegenstelling tot rehabilitatie van patiënten die in de eerste fase van hun problemen verkeren, wordt in de rehabilitatie van patiënten die voor een lange periode zijn opgenomen, meer aandacht besteed aan de vaardigheden, - en dit gebeurt betrekkelijk onathankelijk van de gestelde diagnose. Adler e.a. (1984) spreken in dit verband over: "... an alternative view of chronic mental patients and their adaptation to life which is less iliness-centered and treatment-focused. Quality of life, coping-skills and present adjustment are emphasized." Giel (1982) typeert de posithe en de rol van lang opgenomen patiënten volgens het $\mathrm{zgn}$. "invaliditeits- of gebrekkigen-model" en licht dit als volgt toe: "Ze hebben allen een psychiatrische diagnose, dat will zeggen dat ze ooit ziek werden geacht. Kennelijk zijn ze niet zodanig hersteld dat ze het ziekenhuis kunmen verlaten. Ze nemen misschien wel deel aan een programma van dagelijkse bezigheden, maar niet of nauwelijks aan een behandelingsprogramma dat expliciet of impliciet gericht is op hun herstel. Het zijn doorgaans mensen die moeten leven met een gebrek, in dit geval een geestelijk gebrek. .... Binnen het gebrekkigenmodel als geheel telt de specifieke diagnose minder; meestal valstat men met een benoeming van de handicap in zeer algemene termen ..." "

Bij een dergelijk concept stat dus niet het principe "to restore to a former capacity or state" door middel van behandeling op de voorgrond, max eerder - om een andere definitie van het begrip rehablittatie te gebruiken - "to restore to a condition of useful. and constructive activity (after illness)" (Webster, 1984). De rehabilitatie van lang opgenomen patienten is in de regel niet meer gericht op de complexe vaardigheden in sociale rollen van vóbr de opname, of beter, vóór de start van de ernstüge psychische problemen "Van de meeste patiënten wordt niet meer verwacht 
dat zij hun opleiding afmaken, weer gaan werken, kinderen gaan opvoeden of dagelijkse omgang hebben met een vaste partner. activiteiten war ook menige andere Nederlander problemen mee heeft. Zo waarschuwt Lamb (1979) voor "overselling" van het rehabilitatieconcept bij ernstig gehandicapte patienten door onrealistische verwachtingen en overenthousiaste pogingen wan hulpverleners.

De doelstellingen voor de rehabilitatie van lang opgenomen patiênten zijn beperkter van aara en, zoals Wennink en zuilhof (1984) terecht opmerken, veelal gericht op het aanleren van vaardigheden en het stimuleren van activiteiten dile voor de meeste Nederlanders vanzelfsprekend zijn en routinematig worden gedaan. valgens bovengenoemde auteurs onderscheiden $z i c h$ "chronische" patiënten van "gewone" mensen, doordat ze op enkele onderdelen "de kunst van het leven" zijn verleerd, zoals boodschappen doen, een brief schrijven, fietsen, telefoneren, huishoudelijk werk, ontspanning, lichamelijke verzorging en het omgaan met anderen. Bij het oordeel van hulpverleners of lang opgenomen patienten wel of nilet voor vervangende zorg in a anmerking komen spelen dergelijke vaardigheden dan ook een belangrijke rol. Babiker (1980) wijst erop dat dergelijke vaardigheden reeds na een betrekkelijk kort verblijf essentieel zijn voor het ontslag van patiënten. Zo verschilden patiënten die binnen een half jaar waren ontalagen, wat hun vaardigheden betreft, significant van patiënten die een half jaar na de opname nog steeds in de instelling verbleven. Daarentegen werden nauwelijks verschillen gevonden, wat betreft het aantal en de ernst van de symptomen. De onderzoeker concludeert: "The findings of this study suggest that continued retention is determined by factors other than the patient's clinical. state. The capacity for self-support and independent existence, $\mathbb{1}$ insofar as it can be distinguished from illness, as well as adequate social support ... appear to be the essential ingredients required for discharge."

Hoe vaaraig zijn nu lang opgenomen patienten, en in welke mate spelen vaardigheden een rol bij het oordeel over ontslag naar vervangende zorg? 
Giel (1977) beschreef de vaardigheden van lang opgenomen patiënten als volgt: "... chronic patients, whether schizophrenic or mentally retarded, are on the whole perfectly capable of taking care of themselves with regard to their basic needs: dressing, personal hygiene, food, finding their way about the hospital or hospital grounds. They are generally very quiet people, who talk to themselves if they ever talk, and who initiate littie contact with others, whether patients or staff. During our observations of ward-behaviour, long-stay patients appeared to differ markedly in this respect from short-stay ones who seemed to have developed networks of cormunication".

Dit oordeed is o.a. gebaseerd op het onderzoek van schudel (1976) bij 170 lang opgenomen patiènten. Alhoewel de contacten van lang opgenomen patiënten met medepatiẻnten en personeel dus schaars waren en waak beperkt bleven tot de geformaliseerde gezamenlijke activitelten op de afdeling, beschikten de patiënten in Schudel "s onderzoek vrijwel zonder uitzondering over een grote mate van zelfredzaamheid. We nemen dan ook aan dat een goede Iichamelijke zelfredzamheid een eerste vereiste is om voor vervangende zorg ingedeeld te worden.

H1: Naarmate de basale zelfredzaamheid van lang opgenomen patienten geringer is, komen $z i j$ minder in aanmerking voor vervangende zorg.

Volgens schudel variëerde de mate, waarin de patiënten contact onderhielden met de wereld bulten de insteling, sterk. Vooral de oudere patienten, zij die zeer lang waren opgenomen en degenen met de diagnose schizofrenie, hadden minder contact met de buitenwereld en een lagere score op de schaal van Basale sociale Vaardigheden (BSV) dan de overige patiënten.

Niet de zelfredzaamheld/zelfstandigheid van de 1.0.p. 1ijkt dus het grootste probleem, mar eerder eer tekort aan vaardigheden om aan het maatschappelifke verkeer deel te nemen, zoals telefoneren, gebruik maken van openbaar vervoer e.d.. 
H2: Naarmate de potentiëel soclale vaardigheden van lang opgenomen patiënten geringer zijn, komen zij minder in aanmerking voor vervangende zorg.

Test \& Stein (1976) onderscheiden "activity of daily living skil1s". en "social or interpersonal skills". Deze sociale vaardigheden aangevuld met vaardigheden in beroep en vrije tija, maar ook de houding van patiènten en en aantal voorwardenscheppende factoren op afdelingsniveau, bepalen mede het aantal contacten van 1.0.p. met personen buiten de instelling.

Het aantal externe contacten wan patiënten kan volgens Segal \& Everett-Dille (1980) worden beschouwd als één van de maten van "externe integratie" * Externe integratie wordt daarbij gedefinieerd als de mate warin een patiënt zonder personele begeleiding deelneemt aan gemeenschapsactiviteiten buiten de insteling. De index die segal e.a. voor externe integratie hantexen is samengesteld uit zeven subschalen die de volgende 5 aspecten meten *

a) de verblijfsdurur van een individu buiten de instelling,

b) de toegang tot goederen en diensten die in de gemeenschap beschikbaar zijn,

c) de sociale contacten en deelname aan activiteiten buiten de instelling,

d) de participatie in de gemeenschap door werk of studie, en

e) de activiteiten als consument van goederen en diensten.

Daarnaast hebben Segal e.a. ook een Index ontworpen voor interne integratie, d.w.z. de mate van betrokkenheid van de patiënt bij programa's en activiteiten die binnen of vanuit de instelling platsvinden.

De verschillende vaardigheden spelen in ons onderzoek een belangrijke rol. De vaardigheden worden onderschelden in: basale zelfredzaamheid, potentiëel sociale vaardigheden, interne en externe sociale integratie.

H3: Naarmate de interne sociale integratie van lang opgenomen patienten geringer is, komen zij minder in aanmerking voor vervangende zorg. 
14: Narmate de externe sociale integratie wan lang opgenomen patiduten geringer is, komen zij minder in aanmerking voor vervangende zorg.

\subsubsection{Psychiatriache diagnose}

Orme (1973) stelt dat in principe ledere psychiatrische diagnose ook bij lang opgenomen patiënten te vinden is. Wel zouden in de long-stay populatie een aantal diagnostische groepen oververtegenwoordigd zijn. Orme wijst daarbijo.a. op de patiënten met organische, irreversibele condities met gedragsstoornissen, variërend van epilepsie en preseniele dementie tot relatief zeldzame diagnoses als chorea van Huntington en Wilson's disease. Ook shore \& Shapixo (1979) vragen aandacht voor deze groep namelijk de patienten "... with a variety of conditions that are not primarily psychiatric: advanced korsakow's psychosis, Alzheimer's disease, Pick's disease, and senile organic brain syndrome. These patients end up in state hospitals because there is no other place for them, especially as long-term care in public health hospitals is phased out. They cannot be cared for in nursing homes because of behavioral aberrations" .

Wilder, Lensk zwerling (1966) kwamen op basis van hun onderzoek naar substitutilemogelijkheden van psychiatrische dagbehandeling tot de conclusie dat het met name moeilijk is om voor patienten met "organic brain syndrome" een alternatief te vinden voor het poychiatrisch ziekenhuis.

Bif de bestudering van een cohort van in 1970 in psychiatrische ziekenhuizen opgenomen patienten vonden Giel e.a. (1978) dat mannen met een organische aandoening (anders dan dementie) en vrouwen met dementie of een andere organische aandoening vaker tot de nieuwe chronische patiëntenpopulatie gaan behoren. Door Haveman (1980c) kon deze relatie op basis van een opname-cohort van 1973, alleen worden aangetoond voor mannen tot 65 jaar met een organische aandoening (anders dan dementie).

H5: Als lang opgenomen patiënten een organische psychische stoornis hebben, komen zij minder voor vervangende zorg in aanmerking dan patiënten met andere psychische stoornissen. 
Dok de diagnose "schizofrenie" en "mental retardation" bleek gepaard te gaan met een grotere kans op langdurig verblijf. Voor belde diagnosegroepen gold dit voor de opgenomen mamen en vrouwen in alle leeftijasgroepen.

De beelden, die onder het begrip "schizofrenie" worden samengevat, manlfesteren zich vooral gedurende de late adolescentie en de vroege volwassenheid voor het eerst en treden na het dertigste jaar nauwelijks meer voor de eerste keer op (Giel e.aik, 1980). Een groot deel van deze patiënten blijft ook op hogere leeftijd sterk van psychiatrische zorgathankelijk.

H6: Als lang opgenomen patiënten de diagnose schizofrenie hebben, komen zij minder voor vervangende zorg in aanmerking dan patiënten met andere psychische stoornissen.

Voor het bepalen van de psychiatrische diagnose is in dit onderzoek gebruik gemakt van hoofdgroepen van de 9de versie van de International Classification of Diseases (ICD-9) en DSM III. Dit zijn gangbare classificatiesystemen in psychiatrische ziekenhuizen, die tevens goed aansluiten bij gegevens van de case-registers in Assen en Mastricht, het landelijke registratiesysteem van de GHIGV en bij onderzoek dat elders in Nederland plaatsvindt.

Aan diagnostische aspecten werd in het onderhavige onderzoek betrekkelijk weinig aandacht besteed.

\subsubsection{Geestelijke handicaps}

De geestelijk gehandicapte patiënten (mental retardation) nemen ook ruimtelijk gezien in de psychiatrische ziekenhuizen een aparte plaats in. Over de omvang, samenstelling, diagnostische differentiatie en doorstroming van deze groep is elders verslag gedaan (Haveman, 1981). Gezien de specifieke begeleldings- en verzorgingsbehoefte van diep geestelijk gehandicapten zal deze groep, evenals de groep van demente bejaarden in het onderzoek buiten beschouwing blijven. 


\subsubsection{Gevar voor zichzelf of anderen}

In experimenteel onderzoek naar alternatieve zorgvormen worden valk personen met suïcldaal en agressief gedrag buiten de onderzoeksopzet gelaten (Braun e.a., 1981). Bij deze patienten durfae men het ontslag uit de intramurale setting naar de experimentele semi- of extramurale situatle niet aan. Het is amnemelijk dat suicidepogingen en lichamelijk agressief gedrag ook in de klinische praktijk contra-indicaties zijn voor ontslag. Zo bleek uit onderzoek van Katz \& Woolley (1975) dat artsen, psychologen en maatschappelijk werkers de volgende ontslagcriteria noemden, in volgorde van belangrifkheld:

1. De patiènt is geen gevaar (meer) voor zichzelf of anderen:

2. hij functioneert op een aanvaardbare wijze en berokkent zich zelf en anderen geen schade:

3. de verbetexing van het gedrag is voldoende om zich buiten het ziekenhuis te kunnen handhaven;

4. de psychlatrische symptomen zijn verdwenen;

5. het milieu waarin de patiĕnt kan terugkeren lijkt voldoende stabiel;

6. de patiënt aanvaardt de verantwoordelijkheid voor zijn gedrag.

Zowel in het eerste als ook in het tweede ontsilagcriterium speelt de taxatie van mogelijk gevaar voor zichzelf of anderen een rol. Deze twee aspecten, agressief en sücidaal gedrag, zijn als variabelen in dit onderzoek opgenomen.

17: Naarmate lang opgenomen patiënten agressiever zijn, komen zij minder in aanmerking voor vervangende zorg *

H8: Naarmate lang opgenomen patienten meer sulcidaal zijn, komen zij minder in armmerking voor vervangende zorg. 


\subsubsection{Demografische en jurlidsche factoren}

In 1982 waren bijna evenveel mannen als vrouwen lang opgenomen. Wel hadden de vrouwen een gemidaeld hogere leeftija. Van de verblijfsduurgroep 2-5 jaar was 61 van de vrouwen ouder dan 50 jaar tegenover 468 van de mannen. Voor de vrouwen en mannen met een verblijfsduur > 5 jaar waren de percentages respectievelijk 808 en 71 .

De mannen en vrouwen die in 1973 in psychiatrische ziekenhuizen werden opgenomen en daar lang verbleven (3-4 jaar), waren met gemiddeld 47 jaar en 57 jaar duidelijk ouder bij opmame dan de personen van het totale opnamecohort (Haveman, 1980c). De kans op een langdurige opname nam zowel voor de mannen als de vrouwen met de leeftija toe, voor de vrouwen zelfs van 38 in de leeftijdsgroep van 25-34 jaar tot 128 in de leeftijasgroep van 65-74 jaar. Pas met een leeftijd van onstreeks de 75 jaar kwam hierin verandering. Waarschijnlijk werd dit verschijnsel beinvloed door hogere sterte in deze leeftijasgroep.

Een mogelijke verklaring voor de oververtegenwoordiging van oudere patiẻnten is dat hulpverleners bij hun oordeel over ontslag en vervangende zorg betere kansen zien voor jongere dan voor oudere patienten.

H9: Naarmate lang opgenomen patiënten ouder zijn, komen zij minder in aamerking voor vervangende zorg.

Een andere reden voor de grotere doorstroming van jongere patiênten zou kunnen zijn dat oudere patiënten ook zelf veel minder de wens te kennen geven om van verblijfplaats te veranderen.

H10: Naarmate lang opgenomen patienten ouder zilyn, hebben zij minder de wens orn het psychiatrisch ziekenhuis te verlaten. 
Uit bovengenoemd registeronderzoek bleek tevens dat de nieuwe langverblijvende mannen in vergelijking met het totale opnamecohort 1973 vaker:

- ongehuwd waren,

- opgenomen werden krachtens een rechterlijke machtiging of strafrechtelijke matregel ( $<65$ jaar), en

- vóor de opname in een andere psychiatrische insteling verbleven.

De nieuwe langverblijvende vrouwen bleken waker:

- uit de oudere leeftijasgroepen geselecteera te zijn,

- ongehuwd en gescheiden (>65 jaar) te zijn,

- voor opname bij het ouderlijke gezin te wonen,

- opgenomen te zijn krachtens een rechterlijke machtiging,

- voor de opname in een andere psychiatrische insteliing te verblijuen.

H11: Als lang opgenomen patiënten via een civiel- of strafrechtelijke procedure in het psychiatrisch ziekenhuis verblijven, komen zij minder voor vervangende zorg in aanmerking dan patiënten die daar - juridisch gezien - vrijwillig verblijven.

Geen belangrijke verschillen werden gevonden tussen lang opgenomen patienten en het opamecohort voor kenmerken als opleiding, nationaliteit en urbanisatiegraad van de woongemeente.

Met het verblijf van mannen voór de opname in andere psychiatrische instellingen wordt op een andere belangrijke factor gewezen, namelijk de opnameduur. Zo vonden Pokorny a. (1976) en Rosenblatt Mayer (1974) dat de opnameduur in het verleden de beste voorspeller is voor "chronische hospitalisatie" van patienten in de toekomst. In verschillende onderzoeken bleek dat met de duur van het verblijf in het psychiatrisch zilekenhuis de kansen voor de patient op ontslag en verblijf in de matschappij geringer werden (zie Paul en Lentz, 1977). 
H12: Naarmate patienten langer in het psychiatrisch ziekenhuis verblijuen, komen zij minder in aanmerking voor vervangende zorg.

Demografische variabelen als geslacht, leeftijd, burgerlijke staat, mar ook lengte van verblijf en de juridische status daarvan, zijn gezien het bovenstaande, onderdeel van het onderhavige onderzoek.

\subsubsection{Attitude van patiënten t.a.v. ontslag}

Test \& Stein (1977) stellen dat "... chronically disabled patients demonstrate powerful dependency meeds which were frequentIy expressed as an agressive dependency on family or institutions". In een andere publicatie (1978) schrijven zij at "chronisch psychiatrische patiënten" ... perceive themselves as quite helpless and thus requiring massive support from families or institutions to survive. When this support is threatened, they frequently develop severe psychopathology" "Voor een aantal lang opgenomen patiënten is het bedreigend om de instellingsafhankelijkheid te vervangen door een meer zelfstandig en zelfredzaam leven buiten de instelling. De beschutting en de verzorging van het psychiatrisch ziekenhuis vallen dan weg, en tevens de contaciten die men in de jaren met andere patiënten heeft opgebouwd. Dat betekent dat men plaats en aanzien die men zich binnen de afdeling heeft weten te verwerven, moet inwisselen tegen eventueel minder sociaal aanzien in de matschappij. Volgens wing (1962) bestat er een duidelijk verband tussen de verbliffsauur en de ontslagattitude van de patiënt. Met de verblijfsduur dalt in het algemeen het verlangen van patienten om ontslagen te worden. Desgevraagd bleken tussen de 26 en 338 van de patiënten die 2 tot 5 jaar in het psychiatrisch ziekenhuls verbleven, onverschiliig of negatief te staan tegenover eventueel ontslag uit de instelling. De desbetreffende cijfers voor de verblijfsduurgroep van 10 tot 20 jaar lagen tussen 50 en 598 . De groep met de langste verblijfsduur ( 20 jaar) was met 73 tot $80 \%$ 
tevens het meest onverschillig of negatief over een eventueel ontslag. Alhoewel de minder gehandicapte patiënten een positievere houding hadden ten aanzien wan ontslag, kon ook bij hen de relatie tussen verblijfsduur en ontslagattitude worden vastgesteld. De resultaten van dit onderzoek werden nog eens bevestigd door Freeman e.a. (1965).

zowel de verschillen in de voorzieningen en de organisatie van de geestelijke gezondheidszorg tussen Groot-Brittanië en Nederland, als ook de veranderingen die in de afgelopen 20 jaar in de psychiatrische zorg hebben platsgevonden maken het wenselijk om de vraag nar de relatie tussen verblijfsduur en houding ten aanzien van ontslag te stellen.

H13: Narmate patienten langer in een psychiatrisch ziekenhuis verblijven, hebben zij minder de wens om ontslagen te worden.

ook wordt verwacht dat patiënten die zeer lang ziljn opgenomen de leefsituatie binnen de instelling positiever beleven dan patiënten die minder lang in een psychiatrisch ziekenhuis verblijven.

H14: Narmate patiënten langer in een psychiatrisch ziekenhuis verblijven, is hun houding positiever ten opzichte van de afdeling en instelling.

\subsection{Afdelings- en instellingsfactoren}

De wens van de patiënt om de insteliing te verlaten hangt onder andere af van zijn of haar beleving van de directe leefomgeving (de medepatienten, het personeel, het comfort van wonen en slapen en de activiteiten van bezig zijn en vrije tija). Een negatieve beleving zal zich - zo is de veronderstelling - meer uiten in de wens tot ontslag, een pasitieve beleving meer in een voortzetting van het huidige verblijf. 
H15: Naarmate de houding van lang opgenomen patiënten positiever is ten aanzien van de afdeling en instelling, zullen zij minder de wens hebben om ontslagen te worden.

Kish e.a. (1975) constateren tevens een relatie tussen het behandelingsbeleid op de afdeling en de houding van de patient ten aanzien van ontslag. Naar aanlelding van een door hun uitgevoerd vergelijkend onderzoek bij en aantal psychiatrische afdelingen menen zij at patiënten die voelen dat eigen initiatief op de afdeling beloond wordt, eerder geneigd zijn om het psychiatrisch ziekenhuis te verlaten dan patienten die menen dat zelfstandig gedrag niet gewardeerd wordt.

Anderen zijn van mening dat langverblijvende patiënten in het algemeen positief tegenover ontsiag staan, mar dat de zorgprogramma's veelal niet of inadequat bij deze attitude aansiluiten (Wing, 1966). In dit verband wordt vooral door de "Maudsleyschool" (Wing, Bennett, Freudenberg. Brown) gewezen op het conceptuele verschil tussen behandeling (het reactiveren van psychologische functies en persoonlijke vaardigheden) en rehabilitatie ("a transitional phase with a community orientation, and finally a phase of community integration," Bennett, 1983). Uit een definitie van Lamb (1979) blijkt dat rehabilitatie-activiteiten gericht zijn op concreet rolgedrag buiten de instelling, namelijk: "to raise the level of their social and vocational functioning, to help integrate them into community life, and to give them identities of citizen, worker, or student rather than simply that of mental patient". Watts (1983) citeert in dit verband een onderzoek van walker \& McCourt (1965) warbij geen verband werd gevonden tussen de patiënten die in het ziekenhuis werkten (arbeidstherapie) en patienten die na het ontslag werk hadden gevondien.

De huidige zorgprogramma's voor langverblijvende patienten bestaan vooral uit de $\mathrm{zgn}$. activiteitentherapieün, namelijk arbelds-, bezigheids- en creativiteitstherapie. Alhoewel de daelstellingen van deze zorg niet altijd even duidelijk zijn, bestaat de indruk dat de activiteiten eerder gericht zijn op het zinvol 
bezighouden van patienten binnen de instelling dan op rehabilitatie. Okin (1983) merkt hierover op: "Veel van deze programma"s ... beperken zich tot een klein gedeelte van de dag en zijn vaak eerder bedoeld om hem of haar bezig te houden dan om vardigheden aan te leren die relevant zijn voor het leven buiten de muren van de instelling. Houtsnijwerk, pottenbakken en het werken met papier-mâche zj jn Interessante en soms nuttige activiteiten voor bepaalde patiëten, maar voor anderen dragen zij alleen bij tot de onwerkelijkheid van het instituutsleven. Het isoleert hen nog meer van de "buitenwereld" en onthoudt hun de vaardigheden die ze nodig zullen hebben om daaraan deel te nemen. Ook in de psychiatrische ziekenhuizen war wel geprobeerd wordt on de patienten de vardigheden te leren die zij buiten nodig zullen hebben (zoals koken, gebruik van wasserette, omgaan met geld, boodschappen doen e.d.). zijn deze pogingen slechts beperkt zinvol, omdat deze vaardigheden binnen de instelling nauwelijks in praktijk gebracht kunnen warden" .

Anderen zoeken de belemeringen voor ontslag niet in de inhoud van de zorg, de programma's, maar eerder in a-specifieke zorgfactoren zoals de motivatie van medisch, sociaal-wetenschappelijk en verpleegkundig personeel om zich voor ontslag van patiënten in te zetten (Chien sharaf, 1971; Schudel, 1976).

Ook wordt gewezen op organisatiestructuren die de doorstroming van patiènten zouden belemmeren. Zo wordt ult vele studies (Wilensky \& Lebeaux, 1965; Magaro \& Giardina, 1971; Greenblatt e.a.. 1971: Bachrach, 1976) geconcludeerd dat decentralisatie van de organisatiestructurir in belangrijke mate bijaragt tot een betere reintegratie van personen in het leven buiten de instelling. In Nederland is door Wennink en Zuilhof (1984) verslag gedaan van een evaluatie-onderzoek nar de consequenties van decentralisatie in de vorm van sociowoningen aan de rand van het terrein van een psychiatrisch ziekenhuis. Onderscheiden worden enerzijds, in negatieve zin, terugtrekgedrag en anderzijas, in positieve zin, reintegratie. Deze reIntegratie wordt conceptueel onderverdeeld in vier soorten activiteiten: zelfredzamheid, ondernemende, huishoudelijke en sociale activiteiten. 
Door Van der Zwaan (1982) is een onderzoekmethode geschetst an binnen één psychiatrisch ziekenhuis toegepast warbij effecten. van decentralisatie op de doorstroming gemeten worden en structurele belemmeringen voor de doorstroming herkenbaar worden. Andere auteurs wijzen erop dat decentralisatie een onvoldoende voorwarde is voor grotere doorstroming als daaraan niet tevens een op ontslag gericht behandelingsbeleid gekoppeld is (Liberakis, 1981; Presiy e.a., 1982).

H16: Als voor lang opgenomen patiënten door het behandelend personeel wordt aangegeven dat de zorg niet meer gerlcht is op ontslag, dan zulien deze patienten zelf minder de wens hebben om ontslagen te worden dan patiënten waarvoor de zorg wel op ontslag is gericht.

In Nederland kan in dit verband worden gewezen op de trend om leefgroepen van langverblijvende patiënten te formeren die in aan elkaar gekoppelde laagbouweenheden wonen en slapen. Decentralisatie wat betreft locatie, beheer en organisatie is dan enigsains gerealiseerd, hetgeen echter niet hoeft te betekenen dat ook een grotere doorstroming plaatsvindt. De decentralisatie kan ook heel bewust in de functie-eenheid of cluster "langdurig beschut wonen" worden gerealiseerd.

orme (1973) noemt daarnaast de neiging van bestuurders en behandelend personeel om patiënten naar soortgelijke beheers- en zorgbehoeften in te delen en te behandelen. Hij schrijft: "It is worth noting that long-stay wards tend to be made up of patients of similar management problems. Thus, the witharawn and deteriorated patients are to be found together. One result of this practice is that mutual stumuation is minimal. It can be argued that chronic withdrawn patients can participate more effectively if given the appropriate stimulation by grouping the patients in an heterogeneous rather than homogeneous manner in this respect (Spohn \& Wolk, 1966)". In een vergelijkend onderzoek blj een viertal Nederlandse psychllatrische ziekenhuizen hebben scholte en Uffing (1982) een poging ondernomen om onder andere deze veronderstelling te toetsen. 
H17: Nabrmate de doorstroming van medepatienten op de afdeling groter is, komen lang opgenomen patienten meer in aanmerking voor vervangende zorg.

\subsection{Gezins- en huisvestingstactoren}

Bij de beschrijving van enkele demografische kenmerken van langverblijvende patiënten in psychiatrische ziekenhuizen viel op dat het merendeel wan deze patiẻnten ongehuwd is. Dat geldt zowel voor duegenen die al zeer lang zijn opgenomen als voor de zgn. "nieuwe 1angblifvers" (Gie1, 1978; Haveman, 1980c). Giel verklaart dit verschifnsel door de directe relatie die er tussen burgerifjke stat en de diagnosegroepen bestaat. De diagnose oligofrenie en schizofrenie is volgens hem ten nauwste verbonden met het ongehuwd $\mathrm{zijn}$, dementie vooral met de weduwstat of gehuwd ziljn.

De verklaring voor deze verschillen tussen de twee genoende diagnosegroepen ligt vooral bij het startpunt van de psychische problemen er handicaps. Voor diep geestelijk gehandicapten speelt het probleem in de meeste gevallen al vanaf de geboorte, bij schizofrene patiénten worden premorbide factoren (Farina e.a., 1962; Klein \& Klein, 1968) of primaire handicaps (wing, 1967) meestal gesignaleerd in de adolescentiefase, en bij dementie pas vanaf het senium. Laatstgenoenden hebben aldus veel meer kansen gehad om serieus mee te dingen op de huwelijksmarkt dan eerstgenoemden. Dok de sociale druk die veelal van gezins- en familieleden ultgat om naar huis terug te keren, kan een verklaring zijn, warom betrekkelijk weinig gehuwde mannen en vrouwen lang in een psychiatrisch ziekenhuis werblijwen. Al zijn de relaties tussem de echtgenoten belast door negatieve ervaringen voor of tijdens de opname (Hatfleld, 1978), dan nog blijkt van dit primalre systeem in het algemeen een druk uit te gaan om de opname te beeindigen. Meyers (1977) wijst in dit verband ook op de binding van opgenomen moeders met de kinderen in de thuissituatie. 
Er is echter weinig anleiding om de ervaringen vanuit eerste of incidentele opnemingen te projecteren op de opvangsituatie van lang of zeer frequent opgenomen patiënten. Vooral bij de oudere langdurig zorgathamkelijke patient lijken het gezin en de familie slechts een beperkte rol te spelen. Desondanks wordt een positief verband veromdersteld tussen de aanwezigheid van een thuiamilieu en de indeling voor vervangende zorg.

HI8: Naarmate het thuismilieu van lang opgenomen patienten vollediger is, komen $z i j$ eerder in aanmerking voor vervangende zorg.

Voor de jongere langdurig zorgafhankelijke patiënten liggen de sociale beperkingen minder in de structuur van het primaire milieu besloten, maar meer in de draagkracht en tolerantie van gezins- en familieleden ten aanzien van afwijkend gedrag over een langere periode. Hatfield (1978) heeft in een onderzoek een aantal gezinnen gevraagd om an te geven met welke gedragingen van patiënten men het meeste moeite had. Heel vaak werden ernstige gebreken genoemd bij het vervullen van bepalde taken zaals grote problemen in de zelfverzorging (verwaarlozing, ADL), onbekwaam zijn in het hanteren van geld, en het onvermagen om voor de nabije toekomst concrete plannen te maken. Op de tweede plaats werd door de gezinnen het introduceren van vreemde gewoonten genoemd zoals ongebruikelijke eet- en slaapgewoonten, maar tevens de neiging om ruzie te zoeken, en onachtzaamheid en vernieling bij het gebrulk van dingen in het huis. De gezins-en familieleden waren vaak erg onzeker door bilzarre psychiatrische symptomen zoals vervolgingswaan, het horen wan stemmen en het met zichzelf spreken. pok wist men veelal geen raad met de suicidedreligingen. Soortgelijke bevindingen worden ook gemeld door creere e.a. (1982) naar aanleiding van een onderzoek naar de rol van familieleden bij de opvang van langdurig psychisch gestoorde personen. Als de gezinnen door de opname van betrokkene in een rustiger vaarwater zijn gekomen, dan bestat natuurlijk het gevaar dat voor rust en een stabiel en voorspelbaar leefpatroon wordt geko- 
zen en riet voor de kans op onrust, instabiliteit en onvoorspelbaar gedrag van de patient. Met andere woorden, men staat afwerend of sterk ambivalent tegenover ontslag er acceptatie van betrokkene binnen het gezin.

H19: Waarmate het thuismilieu van lang opgenomen patiẻnten een negatievere houding inneemt tegenover eventueel ontslag naar de thuissituatile, komen de patiënten minder voor vervangende zorg in aanmerking.

Mar ook aan de kant van de jonge langdurig zorgathankelijke patienten zelf vindt een ontwikkeling plaats die silverman (1971) beschrijft als "a drift away from living at home" met als kenmerk: geen vaste woonomgeving, mar verschillende woonsituaties en korte klinische contacten.

Een dergelijk patroon was herkenbar bij een groep frequent opgenomen patiënten die met een gemiddelde leeftija van 39 jaar betrekkelijk jong was (Haveman, 1980b). Ruim de helft van deze patiënten woonde vóbr de eerste opname in het ouderlijk of eigen gezin. Na 3 à 4 jaar was dit aandeel geslonken tot éénderde. In deze periode bleek 338 van de gehuwde mannen en $13 \%$ van de gehuwde vrouwen inmiddels gescheiden te zijn. Het lijkt dat met name de frequent opgenomen mannen door psychische en alcohol-/drugproblemen een zware wissel trekken op hun directe sociale omgeving. Voor de gehuwden kan dit resulteren in echtscheiding. Deze gescheiden personen woonden dan ook voor de latste heropname zelfstandig en wisselden valk van huisvesting.

Robbins e.a. (1978) beschrifven deze groep als de "unwelcome patients" die züch niet aan de normen van het gezin en de gemeenschap kunnen aanpassen, maar die ook niet langdurig in een psychiatrisch ziekenhuls verblijven. Deze personen zijn vaak zonder vaste verblijfplats, daar pensions en sleep-ins hun niet kunnen en willen herbergen, omdat het gedrag storend is voor andere bewoners. Schwartz en Goldfinger (1981) merken op dat bij deze patienten niet al te veel aan ondersteuning door gezin of familie verwacht mag worden. De meeste patiënten zijn inmidals vervreemd 
van hun familie, en kunnen of willen in perioden van arisis niet meer naar hun primaire milieu terugkeren.

Verschillende auteurs (Mannoni, 1974; Talbott, 1979; Armstrong. 1979; Pepper e.a., 1981) wijzen dan ook op het verschijnsel van frequente heropnemingen bij gebrek aan een adequat onderkomen en hulp als men dat nodig heeft. Peppex e.a. menen dat er vooral een gebrek bestaat an zorgverleners in tussenvoorzieningen die het gedrag van deze patiënten kunnen hanteren. "Finally, placements in residential facilities are often precluded by the very behaviours we might want to treat. Given the patients' frequent history of drug abuse, alcoholism, selfdestructive behavior, and acting-out, typical half-way houses and other residential placements are unwilling to accept many of these patients" (Pepper e.a., 1981). Dergelijke kanttekeningen kunnen ook ten aanzien van de Nederlandse situatie worden geplatst. Bij kleinschalige voorzleningen zaals beschermende woonvormen, waar de bewoners zelf zonder al te veel begeleiding langdurig op elkarar zijn aangewezen, is het mogelijk dat een aantal criteria tot opname worden gehanteerd die een verblijf uitsluiten. Welke criteria en hoeveel, dat zal in belangrijke mate afhamgen van de kwetsbaarheid van de instelling, het soort en antal personeelsieden, de samenstelling van de bewonersgroepen, en de opvattingen van leiding en personeel.

In een landelijk onderzoek bij 110 beschermende woonvormen (Haveman, 1982a) werd aan de lelding van deze 1 instelingen gevraagd. welke factoren een verblijf uitsluiten. Door ruim tweederde van de instelingen werden 5 of meer opname-uitsluitende criteria genoema. De meeste restricties speelden ten aanzien van diepzwakzinnigen (93\%), arugsmisbruik (85\%), alcoholisme (75\%), leetija ouder dan 55 jaar (638), acting-out gedrag (558) en geringe zelfredzaamheid (52\%).

Aar zowel de structurele als houdingskenmerken van familie/gezin wordt in het kader van het onderhavige onderzoek arndacht besteed. Centraal staat natuurlijk ook het thema van geschikte huisvesting. Zo zijn ex aanwijzingen at vooral de langer opgenomen patiěnten na ontslag niet meer terug kunnen keren naar hun 
aorspronkelijke woonsituatie. Van den Hout (1985) vond in zijn anderzoek dat meer dan 80. wan de ontslagen patienten weer daar gaat wonen wax men voor de opname verbleef. De patiënten die betrekkelijk lang waren opgenomen, bleken hierop echter een uitzondering te vormen. Beschikbare en geschikte huisvestingsfaciliteiten zijn dan ook van essentieel belang voor de groep van lang opgenomen patienten on woor ontslag in aanmerking te komen (Mann * Sproule, 1972; Christie Brown e.a., 1977). Wel geven nogal wat patiênten de voorkeur aar samenwonen met andere ex-patienten (Vetter, 1985), omdat $z \dot{j}$ vrezen anders buiten de instelling in een sociali isolement te geraken en te vereenzamen.

Wiet alleen het gemis aan huisvesting, ook de structuur, de organisatie en het huldige aanbod van geestelijke gezondheidszorg kan van invloed zijn geweest op de oordeelsvorming van hulpverleners, maar was niet het onderwerp van onderzoek. zo werden in dit onderzoek aan de hoofdbehandelaar geen vragen gesteld over de ervaringen met de nazorg van lang opgenomen patiénten. Toch kunnen zowel positieve als negatieve ervaringen van hulpverleners met andere ggz-voorzieningen (Riagg, beschermende woonvormen, polikliniek, dagbehandeling, soclowoningen e.d.) medebepalend geweest zijn voor hun oordeel over vervangende zorg. Daarbij kan aan een veelvoud van vragen worden gerefereerd: zijn de bedoelde vervangende zorg-vormen in de regio aanwezig, is er nog plaats, welke intake-indicaties worden door deze instellingen gehanteerd, hoe soepel verloopt de samenwerking op hulpverlenersniveau, heeft men wel vertrouwen in de geboden zorg, wordt dagactivering bij deze instellingen flexibel mar goed gestructureera aangeboden. hoe is de crisisopvang 's nachts of in het weekend geregeld, welke aandacht wordt gegeven aan gestructureerde vrijetijdsbesteding, e.d.?

Daarnast is bij de keuze van de variabelen een ander systeemaspect, namelijk de financiering van de zorg en het inkomen van patiënten op basis van sociale verzekeringen, buiten beschouwing gelaten. Toch is het mogelijk dat een afweging platsvindt mede op basis van financiele zekerheid. Het is denkbaar dat zowel de 
behandelaar als de patient zelf zich de vrag stelt, of de overgang nar een meer zelfstandig leven gepaard gat met een verhoging van het te besteden budget, waardoor het daadwerkelijk mogelijk wordt om bijvoorbeeld boodschappen te kunnen doen, uit te gaan en met openbaar vervoer te reizen.

\section{Resumerend:}

In dit onderzoek worat verwacht dat zowel de vaaraigheden van de patient, de gestelde diagnose, de leeftija, het gevaar voor zichzelf of anderen, het thuismilieu als ook enkele instellingsfactoren van invloed $\mathrm{zijn}$ op het oordeel van hulpverleners, om lang opgenomen patiënten wel of niet in anmerking te laten komen voor vervangende zorg. De geformuleerde hypothesen kunnen als volgt schematisch worden weergegeven:

Schema 8: Veronderstelde relaties van onafhankelijke variabelen met de criteriumvariabele "oordeel vervangende zorg"

\section{leeftija \\ H9: oud}

vaardigheden

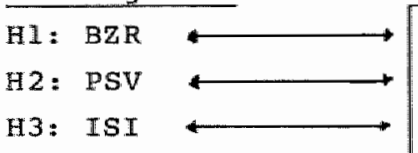

H3: ISI

H4: $\operatorname{ESI}$

diagnose

H5

organ. psych: stoorn.

H6: schizofrenie

H18: onvolledig

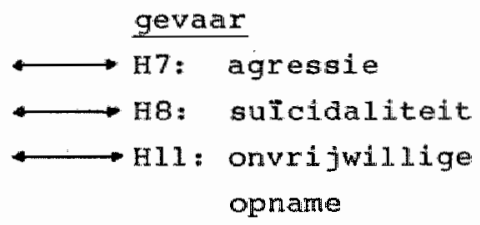

instellings factoren

H1 2: opnamedur

H17: doorstoming afdeling

H19: negatieve houding thuismilieu

Daarnaast werd in de vorm van een vijftal hypothesen een verband verondersteld tussen enkele instellingsfactoren, mar tevens leeftijd, en de houding van patiënten (schema 9). In de inter 
views met de patiënten werd daarbij alleen gevraagd naar de houding tegenover de afdeling en naar de houding ten aanzien van een eventueel ontslag.

Schema 9: Veronderstelde relaties van instellingsfactoren en leeftija met de houding van de patiënt.

instellingstactoren

H1. 4: opnameduur houding $t \cdot a \cdot v \cdot$ instelling

H1 3: opnameduur

H16: ontslaggerichte zorge $\uparrow$ H15:

H10: leeftijd

De resultaten voor de enkelvoudige hypothesen worden besproken in hoofdstuk 12. In dat hoofdstuk is tevens een poging ondernomen om met behulp van een multivariaat model de gezamenlijke invloed te bestuderen van een 9-tal factoren op het oordeel van hulpverleners over ontslag.

\section{Operationalisering en vragenlijsten}

Bij de meeste van de genoemae variabelen spelen beoordelingsmomenten een rol, warvoor ten behoeve van een goede uitvoering specifleke deskundigheid en bekendheld met de patiënt vereist is. Redelijkerwijs mag verwacht worden dat de hoofdbehandelaars en de meest betrokken verplegers of verzorgers deze deskundigheid over en bekencheid met de patiënt zulien bezitten.

Per patient c.q. bewoner werd gebruik gemakt van een drietal. vagenlijsten, warvan de eerste twee door de hulpverleners waren ingevuld en de derde $\mathbb{l i j s t}$ mondeling bij de patiënt $c . q$. bewoner was afgenomen. De vragenlijsten werden aldus benoemd: 
VOL I: Vragenlijst Onderzoek Long-stay I invuller(s): psychiater, psycholoog of maatschappelijk werker;

VOL II: Vragenlijst onderzoek Long-stay II invulier(s): B-verpleegkundige of anverwante functies;

VOL III: Vragenlijst onderzoek Long-stay III invuller(s): externe interviewer (B-verpleegkundige) op basis van informatie van patiënt/bewonex.

\subsection{Vragenlijst Onderzoek Long-stay I (VoL I)}

De vOL I bestond uit 27 vragen (zje bijlage 1). Met uitzondering van enkele open vragen waren alle vragen geprecodeerd en in de meerkeuzevorm gesteld. Met de voL I werden de volgende variabelen gemeten:

- verblijfsduurgroep, psychiatrische hoofddiagnose,

- datum van laatste opname, leeftija. geslacht,

- burgerlijke staat, juridische situatie nu, lichamelijke ziekte of handicap en

- lichamelijke invaliditeit (beperkingen in de functies zien, horen, spreken en lopen).

Daarnaast werd een aantal vragen geformuleerd om de attitude en inzet van het afdelingspersoneel ten aanzien van ontslag van de patiënt (vraag $15 \mathrm{t} / \mathrm{m}$ 19, 21, 22) te meten. Deze variabelen kwamen in dezelfde formulering ook in de voL II aan de orde. Dit bood mogelijikheden om de meningen en attitudes van psychiaters c.s. met die van verpleegkundigen c.s. te vergelijken.

Een aandachtspunt in de voL I was ook het beschikken over een thuismilieu (familie, gezin, e.d.) en de houding van het thuismilieu ten aanzien van een eventuele thuisplatsing.

Voor de psychiatrische dagziekenhulizen en beschermende woonvormen werd een versie van de vol I gehanteerd die slechts op enkele punten afweek van de voL I voor a.p.z.-en. Wel werd in de fase van gegevensverwerking rekening gehouden met de items van deze vragenlijst die of woor één of voor beide soorten instellingen minder relevant waren of een andere betekenis kregen. 


\subsection{Vragenlijst onderzoek Long-stay II (VOL II)}

De VOL II beatona uit 72 vragen (zie bijlage 2), die voor een adequate beantwoording goede bekendheid met de patiënt/bewoner veronderstelder. Voor alle voorzieningensoorten werd én en dezelfde vragenlijst (VOL II) gehanteerd. Op het dekblad van de vragenlijst stond vermeld dat de antwoorden uitsluitend betrekking dienden te hebben op de situatie van patiënten/bewoner over de afgelopen vier weken (tenzij anders vermeld). Met uitzondering van éch vraag waren alle vragen geprecodeerd en in de meerkeuzevorm gesteld.

Het merendeel van de vragen van de VoL II, namelijk 55, had bietrekking op zes index-variabelen:
a) basale zelfredzamheid
b) agressie
c) interne sociale integratie
d) suicidegeneigaheid
e) potentieel sociale vaardigheden
f) externe sociale integratie

ad a: Naar aanleiding van de validiteits- en betrouwbaarheidstoetsing in het vooronderzoek (hoofdstuk B) werd "basale zelfredzaamheid" gemeten door een 14 -tal items van de subschalen "hulpbehoevendheid" en "lichamelijke invaliditeit" van de Beoordelingsschal voor Oudere Patiënten (BOP).

ad b: Tevens werd verondersteld dat 4 items van de subschal "agresiviteit" van de BOP "agressie" bij lang opgenomen patiènten meten.

ad c: Daarnaast werd van 6 items van de BoP aangenomen - waarvan 5 uit de subschaal "inactiviteit" - dat zij een indicatie zijn van de mate van aanpassing van patiënten binnen de instelling. Door deze items wordt vooral de contactfrequentie en -intensiteit van de patiënt met gebeurtenissen en personen binnen de instelling weergegeven. Dit verschijnsel zal in het vervolg "interne sociale integratie" worden genoemd. 
ad d: Met behulp van twee vragen werd tevens een poging ondernomen om het aspect "suicidaliteit" te meten. Het ene item had betrekking op het aantal sulcidedreigingen, het andere item op het aantal sulcidepogingen in de afgelopen arie maanden. Het fenomeen "automutilatie" is bij de formulering van deze items buiten beschouwing gebleven.

ad e: Potentieel sociale vaardigheden zijn varalgheden die van belang zijn om zelfstandig buiten de instelling te kunnen leven. In dit verband werden 4 items geformuleerd die betrekking hebben op het in staat zijn van mensen on zelfstandig van het openbaar vervoer gebruik te maken, een eenvoudige maltijd te berelden, boodschappen te doen, en iemand op te bellen. Zoals in de handleiding voor het invullen van deze items was aangegeven, veronderstelt elk van deze vaardigheden wederom het adequat uitvoeren van deelhandelingen, zoals bijvoorbeeld het beheren en besteden van geld en communicatie met anderen in de rol van consument van goederen en diensten.

Aan de beoordelaars werd gevraagd niet het daadwerkelijk vertoonde gedrag van patièten/bewoners aan te geven, maar de ingeschatte mogelijkheden van betrokkenen tot het uitvoexen van het omschreven gedrag.

ad $\mathrm{f}$ : Met externe sociale integratie wordt bedoeld de daadwerkelijke contactfrequentie en -intensiteit van de patiënt/bewoner met gebeurtenissen en personen buiten de instelling. Aan de hand van 20 items werd gevraagd naar activiteiten als telefoneren, schrijven, brieven ontvangen, arderen bezoeken, bezoek krijgen, vacantie, vrije-tijds activiteiten buiten het terrein van de instelling, mar ook bijvoorbeeld krant lezen en televisie kijken.

\subsection{Vragenlijst Onderzoek Iong-stay III}

Met de VoL III werd een poging ondernomen om bij de patient zelf de houding ten aanzien van eventueel ontslag te meten, als ook de houding ten aanzien van de afdeling/instelling waar betrokkene verblijft. 
De volgende a priari elsen werden aan de te ontwikkelen vragenlijat gestela:

- begrijpelijk poor de meeste bewoners/patienten

- kort

- hanteerbaar in de arie voorzieningensoorten

- vergelijkbar tussen de drie voorzieningensoorten

- efficient In de verwerking van de gegevens.

Getracht werd een meetinstrument te construeren, waarbij de begrijpelijkheid van de vragen voor de respondent optimal was. Na verschillende proefversies werd uiteindelijk gekozen woor een geprecodeerde interviewlijst in boekvorm met per bladzijae én vraag met 4 antwooramogelijkhedem (bijlage 3). Tien vragen van de VOL III hadden betrekking op de houding ten aanzien van ontslag en 15 vragen op de houding ten aanzien van de afdeling c.q. instelling.

In het vooronderzoek bleken de twee howdingsindices voldoende geldig en betrouwbar te zijn. De steekproef waraan dit werd getoetst, was echter klein $(N=33)$ en bleef beperkt tot patiënten van psychiatrische ziekenhuizen.

7.3.I. VOL III: versie psychiatrische dagziekenhulizen en beschermende woonvormen

Tijdens het vooronderzoek bleek dat de formulering van bepalde 1tems niet altijd even goed paste in de belevingswerela van enkele tientallen eveneens aan het vooronderzoek deelnemende bewoners van an het PMS Vijverdal verbonden beschermende woonvorrien.

Zo is bijvoorbeeld binnen de beschermemde woonvormen geen sprake van afdelingen, zodat dit woord bij bewoners van deze instellingen in vragen niet gebruikt kan worden. Omdat de vol III echter in alle voorzieningensoorten afgenomen moest kunnen worden, waren sommige vragen met betrekking tot de afdeling geherformuleerd op instellingsniveau. Deze anpassingen werden foor de interviewer aan de hand van een toelichting telkens voorafgaand aan de betreffende intervilews in de vragenlijst angebracht. Bij het 
drukken van de VOL III kon zo met éen standaardversie worden volstaan. De schriftelijke toelichting ging tevens in op begrippen, die tat meer interpretaties van het item aanleiding zouden kumnen geven.

On enige informatie te verkrijgen omtrent de situatie, warin het vraaggesprek zich heeft afgespeeld, was de interviewer gevraagd na afloop van elk interview een evaluatieformuler in te vulien. In dit evaluatieformulier werden 8 geprecodeerde vragen gesteld nar de toestand van de patient/bewoner tijdens het interview en enige open vragen naar storende invloeden op de interviewstuatie. Tot slot werd de tijdsduur van het interview genoteerd. Het evaluatieformulier werd in ongewijzigde vorm zowel in het vooronderzoek als het landelijk onderzoek toegepast.

\section{Ontwikkeling en toetsing van de indices van de vol II}

Het vooronderzoek werd in de periade september $1983 \mathrm{t} / \mathrm{m}$ februari 1984 uitgevoerd in het Psychomedisch Streekcentrum Vijverdal te Mastricht en had betrekking op 212 patiënten van zogenaamde long-stay afdelingen. Van deze patiënten was $50 \%$ langer dan 5

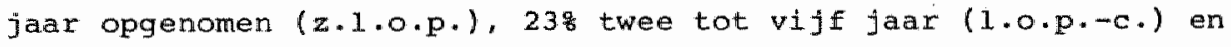
was 5: lang maar discontinu opgenomen (1.0.p.-dc*). De overige 22 영 had een kortere verbliffsduur en voldeed dus niet aan de 1.o.p.-omschrijving. Ondat in het P.M.S. Vijverdal behoefte bestond an terugkoppeling van gegevens op afdelingsniveau, zijn in het vooronderzoek ook de gegevens van de niet-1.o.p. verwerkt en geanalyseerd (Haveman \& Poelijoe, 1984).

Voor 208 patienten (98\%) werd een eerste versie van de Vol. II ingevuld en geretourneerd. Deze groep patiënten bestond voor 538 uit personen ouder dan 55 jaar en was voor 60 s samengesteld uit vrouwer.

De doelstelling wan ait vooronderzoek was tweeledig. Het was een eerste test van eer tweetal onderzoeksinstrumenten, de voL II en Vol III. Tevens was het een waardevolle oefening ten anzien van de onderzoeksorganisatie. Ondex het laatste wordt verstaan: de introductie van het onderzoek bij de instelling, de procedures 
van gegevensverzameling, de verwerking en analyse van de gegevens, en niet te vergeten - de confrontatie met een aantal administratieve procedures die veel tijd eisen mar essentiëel zijn voox onderzoek zoals het verzenden van stukken, de monitoring van geretourneerde vragenijjsten, het rappeleren bij non-respons, het opbergen en clasificeren van literatuur, het drukken van vragen1ijsten, het aantrekken van interviewers, de financiering van de interviewers, et de organisatie van intern en extern overleg over het onderzoek.

$\mathrm{Na} \pm 3$ maanden werd bij 148 patienten de invulling van de VoL II herhadi, maar dan door een andere beoordelaar. Het aantal patienten op het tweede meetmoment (december "83/januari "84) was kleiner dan bij de eerste meting, omdat bij enkelle afdelingen alleen elke tweede patient nogmals werd gescoord om de arbeidsbelasting voor het onderzoek niet te groot te laten worden.

\subsection{Validiteitscontrole van indices}

\subsubsection{De Beoordelingsschal voor oudere Patiënten (BOP)}

Van de 72 items van de VOL II zijn 35 integraal afkomstig uit de BOP. De BOP is de Nederlandse versie van de stockton Geriatric Rating Scale en werd door Van der Karn, Mol en Wimmers (1971) in ons land geintroduceerd voor het meten van de hulpbehoefte van verpleeghuisbewoners. De 35 items van de BOP hebben betrekking op geobserveerd gedrag gedurende een vastgestelde periode en kunnen botrekkelijk snel door verpleegkundig of verzorgend personeel op een ordinale 3-puntsschaal. worden gescoord. Alle items zijn in de stellende vorm geformuleerd.

Gezien deze kenmerken was de BOP geschikt om samen met de andere index-variabelen opgenomen te worden in de vragenlijst voor verpleegkundigen (VOL II). Veel belangrijker was dat er tevens aanwijzingen bestonden dat de BOP een geschikt instrument is voor het meten van hulpbehoevendheld van kort (Baas e.a., 1984), maar vooral lang opgenomen psychiatrische patiënten (Offerhaus, 1976: Diesfeldt, 1981; Koopmans e.a., 1982). 
Naar aanieiding van een onderzoek bij chronische patichten merkt offerhaus als eindconclusie op: "... dat de BOP een valide en relevante vragenlijst is gebleken voor het psychiatrisch inrichtingsmilieu" . In vergelijking met een uitgebreide ADL-lijst met 165 items bleek; "... dat slechts ten aanzien van de elementen "zelfstandig wassen" en "zelfstandig aankleden" de ADL eigen en andere informatie aandraagt, in vergelijking met de Bop* . Toepassing van de BOP in de psychiatrie is echter niet geheel zonder problemen. Eến probleem is het gemis aan afgrenzing in frequentie en tijd van en aantal antwoordcategorieën. zo is onduidelijk of twee keer slaan of schoppen in de afgelopen mand als "soms" of "dikwijls" gescoord dient te worden. Vooral in een sector met zeer verschiliende verblijfsituaties, varierend van sociowoning tot een verblijfsafdeling voor korsakow patienten, en van een therapeutische gemeenschap tot een gesloten afdeling met veel patiẻnten met agressief gedrag, leidt dit tot inconsistente antwoordpatronen. Beoordeling van gedrag is onder andere afhankelijk van de setting war het gedrag wordt vertoond en de hulpverlener werkt. Als voorbeeld kan verwezen worden naar de eerste vraag van de BOP:

I Bedreigt anderen door woord (bijv. "ik zal je krijgen") of gebaar (bijv. vuist schudden).

0 - nooit

1 - soms

2 - dikwijls

Het is denkbaar dat de persoon aie dergelijk gedrag in de therapeutische gemeenschap in de afgelopen 4 weken drie keer heeft vertoond, als "dikwijls" wordt gescoord, terwijl hetzelfale gedrag in een gesloten afdeling met het praedicalt "soms" wordt voorzien. Niet alleen de frequentie van het gedrag is dus van belang voor het oordeel, max ook de contekst waarin het plaatvindt (bijvoorbeeld het gedrag van de medepatienten). Om dit probleem zoveel mogelijk te voorkomen is bij 15 items de periode en/of de frequentile van gedrag gespecificeerd. 
Een ander probleem bij het hanteren van de Bop voor psychiatrische patienten is de scheve verdeling var antwoordscores op enkele items. Gedrag dat bij demente bejaarden vaak voorkomt, zoals incontinentie, orientatiestoornissen en dergelijke, is zeldzam bij lang opgenomen psychiatrische patiënten. Voor een antal statistische analyses levert dit problemen op. Een mogelijkheid om dit enlgsins te ondervangen zonder al te veel te hoeven te veranderen aan de BOP, is het aamouden van een ruimere periode voor beoordeling of lagere frequenties van het te beoordelen gedrag. Dit is bij 2 items gebeurd $(4,32)$. Wiet alle subschalen van de BOP waren voor de vraagstelling even relevant. Er is uitsluitend gebruik gemakt van de subschalen: hulpbehoevendheid, agressiviteit, lichamelijke invaliditeit en inactiviteit. Ondat de BOP voornamelijk geijkt is voor demente bejaarden, maar tevens bij enkele items de frequentie- en tijdmaten zijn toegevoegd, werd de intrinsieke afwel factoriezle valiaiteit van de subschalen voor de hier bedoelde populatie in het vooronderzoek nagegaan.

De in dit verband uitgevoerde factoranalyse had betrekking op 201 beoordelingen. Van 7 patiënten ontbraken gedeeltelijk de gegevens.

Bij een eerste analyse zonder varimax-ratatie werden 11 factoren onderscheiden met een eigenwaarde groter dan 1 . Slechts bij 3 factoren (I, II, IV) kwamen factorladingen van items voor die groter waren dan 50 . De items van de volgende Bop-subschalen bleken op Factor I met $>.40$ te laden:

- hulpbehoevendheid $(-25,26,30,34 ;+35)$

- Iichamelijke inwaliditeit (alle items)

- psychische invaliditeit (alle items)

- inactiviteit (alle items).

Factor II was samengesteld uit zowel items van de subschaal agressiviteit $(-5)$ als ook depressiviteit $(-8)$.

Het onderscheidend vermogen van deze eerste analyse ten aanzien van de Bop-subschalen was dus nog betrekkelijk gering. Vervolgens werd de factormatrix orthogonal geroteerd volgens de varimaxmethode. In bijlage 4 zijn hiervan de resultaten weergegeven. 
Aan de linkerkant van de desbetreffende tabel zijn de items per subschal van de Bop vermeld, terwijl bovenaan 9 van de 11 factoren zijn benoema. De twee overige factoren hadden geen items met ladingen $>.40$.

Sommige items van de BOP worden bij dit instrument niet alleen voor de subschaal "hulpbehoevendheid" gebruikt, mar ook voor de subschalen inactiviteit, lichamelijke of psychische invaliditeit. De desbetreffende items zijn gekenmerkt door nummers tussen halajes.

De subschalen "agressiviteit" (2) en "depressief gedrag" ( $3^{b}$ ) van de BOP waren apart herkenbaar als Factor II en Factor IX. Alle desbetreffende items hadden een factorlading van $>.50$. De subschaal "lichamelijke invaliditeit" viel grotendeels samen met Factor $V$. "Hulp bij aankleden" (item 31) laadde slechts gering (0.26) op deze factor. Wel bestond gemeenschappelijkheid op imhoudsniveau met het item 33 (speciale voorzieningen voor uit bed valien), - een item dat in de BOP alleen tot het aspect. "hulpbehoevenaheid" wordt gerekend.

De vier iterns voor het meten van "psychische invaliditeit" zijn in de BOP tevens bedoeld voor het meten van "hulpbehoevendheid". In de woorliggende factormatrix was deze subschaal niet apart herkenbaar. De items scoorden zowel bij Factor I als Factor VI, factorem die veel duidelijker binnen de subschaal "hulpbehoevendheid" benoembar waren.

Het meest heterageen in factorstructuur was de subschaal "hulpbehoevendheid" (H). Binnen dit concept konden vijf factoxen worden onderscheiden, namelijk:

$H_{1}$ - oriëntatie en lichamelijke redzaamheid (factor I)

$\mathrm{H}_{2}$ - incontinentie (factor IV)

$\mathrm{H}_{3}$ - basale communicatieve vaaraigheden (factor VI)

$\mathrm{H}_{4}$ - bizar gedrag (factor VII)

$\mathrm{H}_{5}$ - nachtelijke onrust (factor VIII). 
Tenslotte bleken op Factor III alleen items te scoren die de particlpatie van patiênten an het gemeenschapsleven binnen de insteling aangaven. Het ging darbij on de volgende items:

18 - Is ook bulten de therapie actief (bv. werken, lezen, spelletjes doen, hobbies, met anderen praten).

20 - Gaat met éen of meer bewoners om.

22 - Helpt andere bewomers wel eens ongevraagd een handje (bij wandelen, eten, spel e.d.).

23 - Is bereid te doen wat hem/har gevraagd wordt.

27 - Knoopt uit zichzelf een pratje aan met andere bewoners.

Terwijl de eerste vijf "hulpbehoevendheid"-factoren ernstige stoornissen en handicaps in primaire lichamelijke en psychische functies meten wa Factor III vooral samengesteld uit items die socialle activiteiten van de patiënt binnen het instituut aangever. Verondersteld mag worden dat goede scores op de factoren van basale zelfredzamheid $\left(\mathrm{H}_{1}-\mathrm{H}_{5}\right)$ en lichamelijke invaliditeit (Factor V) een noodzakelijke voorwaarde zijn voor het actief deelmemen aan het sociale leven binnen de instelling (interne sociale integratie).

De 23 items van de subschaal "hulpbehoevendheid" van de BOP (excl. de 5 items van Factor III) en de 2 items van de subschaal "zelfredzaamheid" in het geheel dus 20 items, vormden zo in eerste instantie de index voor basale zelfredzamheid. Van de vijf items van Factor III werd aangenomen dat deze interne socia1 integratie meten. Tevens leek de subschal "agressiviteit" met har 5 items een geschikte index. 
8.1.2. De intrinsieke validiteit van de vOL II-indices: gegevens van vijf psychiatrische ziekenhuizen

op dezelfde manier als de Bop-items, waren ook de andere ltems van de VoL II voor het aspect suicidaliteit (2), potentiel sociale vaardigheden (4) en externe sociale integratie (18) geformuleerd als 3 -punts items in een ordinale schaal (zie bijlage 2).

Voor de landelijke gegevens is met behulp van factoranalyse nagegaan of deze items samenhangen met de veronderstelde concepten $c . q$. indices. Tabel 1 lat de resultaten van de factoranalyse zien ma een eerste varimaxrotatie. Voor de 381 patienten van de psychlatrische ziekenhuizen konden een 14-tal factoren worden onderscheiden met een eigenwarde groter dan 1 . Alleen ladingen $>.50$ op de factoren zijn in dit overzicht opgenomen. 


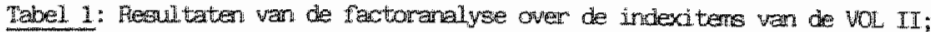
landelik ondkarwod.

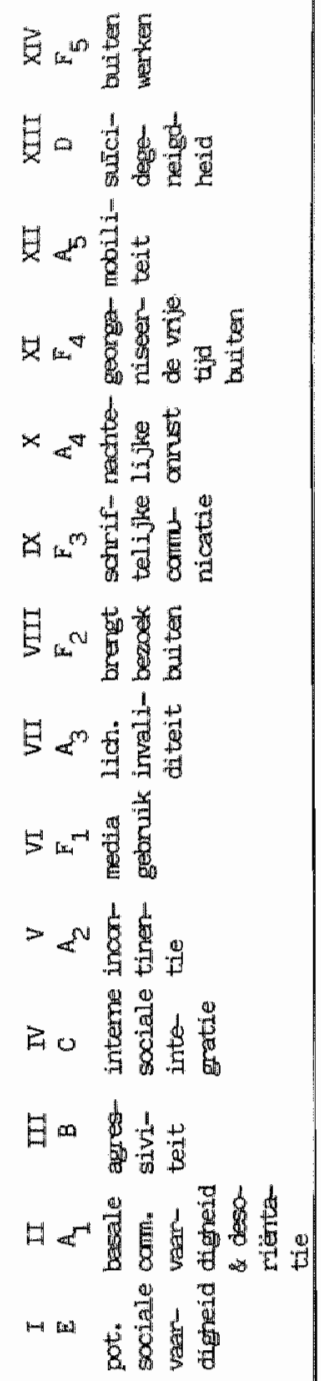

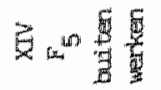

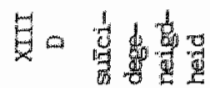

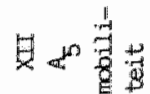

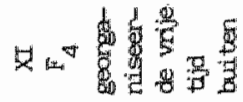

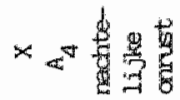

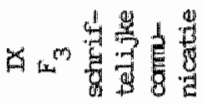

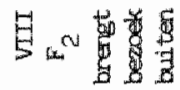

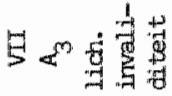

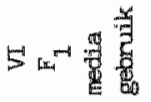

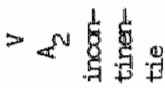

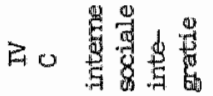

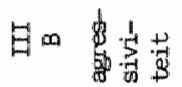

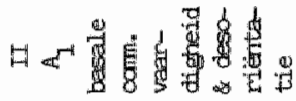

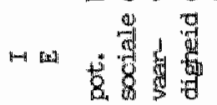

$\stackrel{8}{0}$

量

$\stackrel{8}{0}$

9
0
0

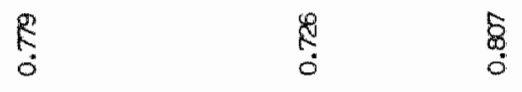

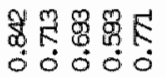

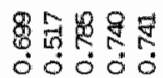

题

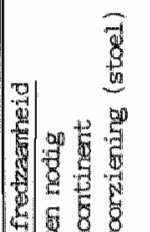

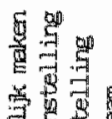

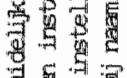

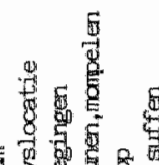

焉

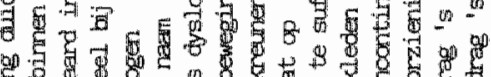

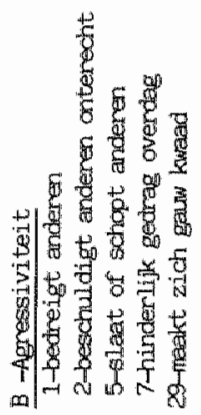




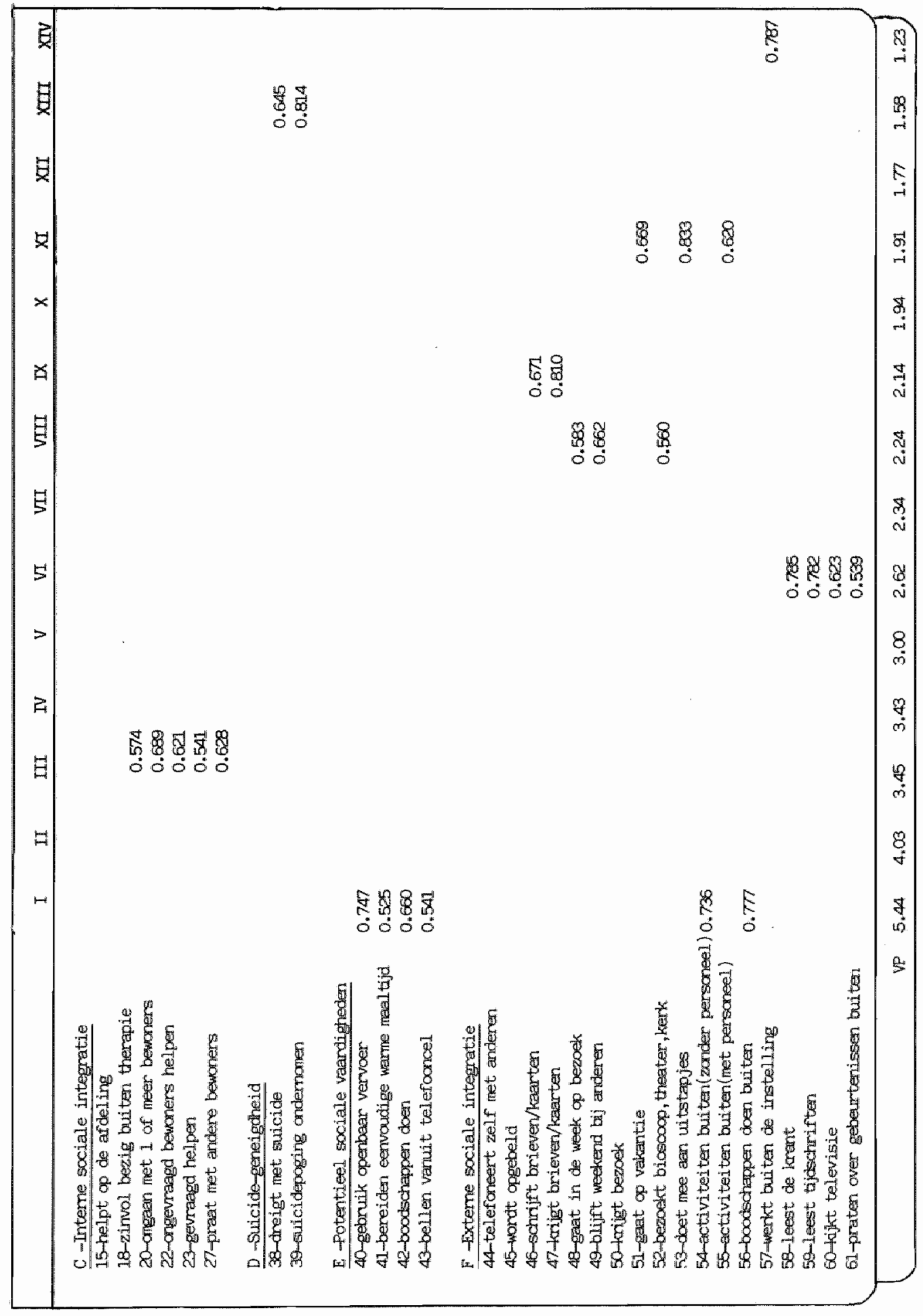


Van de 20 items voor het aspect basale zelfredzaamheid (BZR) laden 13 hoog op de factoren II, V, VII, X en XII. Deze factoren kunnen als volgt worden benoemd:

II - basale communicatieve vardigheid desorientatie: it ens $10-14$

$\mathrm{V}$ - incoritinentie: items $4,21,32$

VII - lichamelijke invaliditeit: items 6,33

x - nachtelijke onrust: items 34,35

XII - mobiliteit: item 9

Ondat voor patienten in psychliatrische dagbehandeling "nachtelijke onrust" moeilijk door het verpleegkundig personeel te beoordeLen was, zijn deze items buiten de BzR-index gelaten. De items wan de factoren II, V, VII en XII meten de essentie van de BZR. Daarbij zijn nog een arietal items gevoegd, namelijk:

- Item 3: hulp bij eten

- item 17: reageert op naam

- item 31: hulp bij aankleden.

De uiteindelijke $B Z R$-index die per patiënt werd berekend bestond uit 14 items, met een minimale tataalscore van 0 (= goed zelfredzaam) en een maximale score van 28 (= slecht zelfredzaam).

Alle 5 agressiviteits-items waren apart herkenbaar binnen één factor (III). Bij de berekening van de AGR-index is alleen uitgegaan van vier items, met een minimale totaalscore van 0 l=geen agressief gedrag) en een maximale van 8 (= veel agressief gearag). Item 7 "hinderlijk gedrag overdag" is, door de anderssoortige betekenis op inhoudsniveau, buiten berekening van de index gelater.

Vijf van de zes items voor interne sociale integratie hadden een hoge lading ( $>.50$ ) op factor IV. Alleen item 15 had met. 40 een lagere warde. De ISI-indexscore wordt in het vervolg over alle $z$ es items berekend met een minimumscore van o (= goede ISI) en een maximum van 12 (= slechte ISI).

Beide suicidaliteits-items scoorden hoog op factor XIII. Binnen de sul-index werden de scores voor een daadwerkelijke suicidepoging twee keer zo zwaar gewogen als de scores voor het dreigen met sulcide. De somtotalscore 0 geeft an dat in de drie manden 
voorafgaand aan de beoordeling geen sprake was van suicidaliteit, een score van 6 dat in deze periode zowel meerdere keren een suicidepoging is aangekondigd als ook daadwerkelijk ondernomen. Alle vier items foor het meten van potentieel socialle vaaraigheden vertoonden inhoudelijke samenhang met factor I. Maar ook de vragen 28, 54 en 56 laadden hoog op deze factor. Desondanks werd de PSV-index beperkt tot de vier items, om het accent op "moge1ijk gedrag" te warborgen. Deze index heeft een minimale waarde van 0 en een maximale $\operatorname{van} 8$ ( $=$ slechte PSV).

Evenals bij het concept "basale zelfredzaamheid" kunnen ook bij externe sociale integratie en vijftal subdimensies worden onderscheiden, namelijk:

VI - mediagebruik: items 58-61

VIII - brengt bezoek buiten: items $48-49,52$

IX - schriftelijke cormunicatie: items 46-47

XI - georganiseerde vrije tijd buiten: items $51,53,55$

XIV - buiten werken: item 57.

Daar tevens de items $24,28,44-45,50$ en 54-55 met $>.40$ een samenhang vertoonden met bovengenoemde factoren werd besloten de 20 a priori-items tezamen de somtotaalscore voor de ESI-index te laten bepalen. De minimumscore is dan 0 (goede EsI) en de maximumscore 40 (slechte ESI).

De factoranalyse geeft een indruk, welke items onderling samenhangen en welke niet. Daarnaast kan met behulp van zgr. Cronbach's alpha ook de mate van homogeniteit ofwel interne gelijksoortigheid van iedere index worden bepald. Als de homogeniteitscoëficiènt een waarde van $>.60$ te zien geeft, dan kan worden aangenomen dat de indexttems voldoende gelijksoortig zijn. In tabel 2 is de alpha-mat voor alle samengestelde variabelen (indices) per voorzieningensoort berekend. 
Tabel 2: Honogeniteit (coefficiênt alpha) van de indices.

\begin{tabular}{|c|c|c|c|}
\hline indices & APZ & $\mathrm{PDB}$ & BWV \\
\hline $\begin{array}{l}\text { - basale zeleredzaamheid (BzR) } \\
\text { (14 Items) }\end{array}$ & 0.89 & 0.57 & 0.59 \\
\hline $\begin{array}{l}\text { - potentiél soc. vaardigheden (PSV) } \\
\text { (4 ittems) }\end{array}$ & 0.89 & 0.86 & 0.73 \\
\hline $\begin{array}{l}\text { - interne sociale integratie (ISI) } \\
\text { (6 ittems) }\end{array}$ & 0.84 & 0.83 & 0.78 \\
\hline $\begin{array}{l}\text { - externe sociale integratie (ESI) } \\
\text { (20 items) }\end{array}$ & 0.85 & 0.86 & 0.80 \\
\hline $\begin{array}{l}\text { - agressiviteit (AGR) } \\
\text { (4 items) }\end{array}$ & 0.81 & 0.70 & 0.81 \\
\hline $\begin{array}{l}\text { - suicldaliteit (SUI) } \\
\text { (2 items) }\end{array}$ & 0.47 & 0.23 & -0.03 \\
\hline
\end{tabular}

Met uitzondering wan de suI-index vertoonden de indices een behoorlijke tot goede interne consistentie. Wel moet worden opgemerkt dat de BZR-index voor doelgroeppatiënten van centra voor psychiatrische dagbehandeling en beschermende woonvormen niet erg homogeen is.

\subsection{Betrouwbararheidscont role van indices}

In het oordeel ower menselijke gedragingen ligt zowel het te meten gedrag van de patiënt zelf besloten (bv. frequentie van incontinentie 's nachts), als ook kan vertekening optreden door de beoordelaar. Beoordelaars kunnen over het bedoelde gedrag bij dezelfde patiént onderling wan mening verschillen door andere normen en waarden, stemingen gedurende de dag en gebrekkige informatie, maar ook door het hanteren van verschillende criteria voor het benoemen van gedrag.

Nu is men als onderzoeker meestal geinteresseerd in het "werkelijke" gedrag van de patient, en niet in een daarvan afwijkende interpretatie of perceptie door de beoordelaar. Men zal dan ook. zoveel mogelijk proberen om de subjectieve interpretatieruimte van de index-itens te beperken. 
Grote overeenstemming tussen twee onafhankelijke beoordelara over het gedrag van dezelfde patiënt vormt dan ook een belangrijke indicatie dat dezelfae matstaf bil de beoordeling van gedrag werd gebruikt en dat daadwerkelijk het bedoelde gedrag wordt gemeten. Bij geringe overeensteming daarentegen zulien, indien mogelijk, de verschillende foutembronnen nader moeten worden onderzocht, te weten de interpretatieruimte van de items (mate van abstractie, openheid van vragen e.d.), de verschillen tussen beoordelaars (attitudes, informatie over de patiënt, werkervaring e.d.) en de veranderingen bij de patiënt (indien de beoordelingen op twee verschiliende tijdstippen hebben plaatsgevonden).

Een dergelijke toetsing van de inter-rater-betrouwbararheid kan niet alleen op itemiveau, mar ook op indexniveau worden uitgevoerd. Bij het laatste is men niet geinteresseerdin de variaties in itemscores, mar in indexscores.

Bij de bepaling van de inter-rater-betrouwbatheid kan tussen twee designs worden gekozen: de simultane procedure of de sequentiële procedure (test-hertest). Bij de simultane procedure wordt het gedrag van de patient gelijktijaig door twee onafhankelijke beoordelaars gescoord. Dit design heeft als voordeel dat het inconsistent scoren van beoordelaars niet verklaard kan worden door eventuele verschillen in gedrag van de patient gedurende verschillende observatieperioden. Uit onderzoek naar de betrouwbaarheid van bijvoorbeeld psychiatrische diagnostiek is bekend (Slooff e.a., 1983) dat de simultame procedure een grotere mate van overeensteming te zien geeft dan de sequentielle procedure. Dit is op zich niet zo verwonderiljk, omdat een bron var variantie bij de simultane procedure is verdwenen, namelijk inconsistentile in het gedrag van de patient. De simultane procedure voorkomt ook een ander probleem, namelijk systematische verschillen in scoringsgedrag door meer ervaring met het instrument in de tweede ronde.

Ondanks de genoemde voordelen van de simultane procedure is bij het bepalen van de inter-rater-betrouwbarheid voor de sequentiẻle procedure gekozen. 
Het bellangrijkste argument roor de keuze van deze vorm van betrouwbarheidsmeting was dat het instrument getoetst moest worden bij beoordelaars die zich gedurende het vooronderzoek in dezelfde situatie bevonden als de beoordelars later in het landelijk onderzoek. Dat betekent dat er van uitgegaan diende te worden dat de vol I binnen de diensturen op de afdeling wordt ingevuld. warbij een groot aantal storende omgevingsfactoren een rol kan spelen: telefoongesprekken, patiêntcomtacten, gesprekken met collega"s, tijdsgebrek e.d. zo kan een instrument dat in min of meer ideale omstandigheden betrouwbaar is gebleken ten dienste en onder het wakende oog van de wetenschap, bij hat practische toepassing in veldonderzoek aanzienlijk minder betrouwbaar zijn. Nu is ét van de belangrijkste voorwateden voor het berekenen van de inter-rater-betrouwbarheid dat de beoordelingen onafhankelijk van elkar plaatsvinden. In een laboratoriumsituatie kan de onderzoeker daarbïj de omstandigheden zo construeren dat eer. dergelijke onathankelijkheid in oordeel bestat. Op de afdeling, in een "in vivo"-situatie, zijn er ten aanzien van de simultane procedure weinig warborgen dat aan deze voorwaarde kan worden voldaan. Het personeel gaat als team intensief met elkaar om, en de eis van onafhankelijkheid en eigen oordeel bij het invullen van de vragenlijst strookt niet met de athankelijkheid en samenwerking in de werksituatie. Vooral als de beoordeling tegelijkertijd plaatsulnat door veel personeelsieden van verschillende afdelingen, valt het voor de onderzoeker moeilijk in te schatten of aan het onafhankelijkheidscriterium is voldaan. Bij de sequentiole proceare speelt dit probleem minder. Na een periode van bijvoorbeeld twee a drie manden bestaat enige zekerheid dat de eerste beoordelaar niet meer weet hoe precies per patiënt een item wera gescoord. Betrokkene kan dan ook nauwelijks de tweede beoordeling beinvloeden. Geen inhoudelijk, mar een belangrijk practisch voordeel van de sequentiéle procedure is, dat de werkbelasting voor het onderzoek over een langere periode wordt gespreid. 
De periode tussen test en hertest was in dit onderzoek met 2 a 3 maanden betrekkelijk lang. Eet mag dan ook niet worden uitgesloten dat de overeensteming tussen de beoordelaars werd geschad door instabiliteit van het gedrag/toestandsbeeld van de patient.

Van de 208 patiënten warvoor in het vooronderzoek in septemberoktober 1983 voor de eerste keer de VOL II werd afgenomen, werd van 148 patiënten een tweede beoordeling verkregen. De overige patienten waren of ontslagen (3), of bij vergissing beoordeeld door dezelfde verpleegkundige (18), of vielen af, doordat bij vier afdelingen slechts de helft van de patienten van de eerste ronde opnieuw werd beoordeeld (35). Voor 4 patiënten was niet bekend waron geen hertest werd gedaan.

Zowel aan de test als de hertest werd door 43 beoordelaars deelgenomen, voornamelijk door verpleegkundigen. De invulling diende onafhankelijk, dus zonder informatie over de eerste beoordeling te geschieden. Van alle beoordelaars, dus ook de beoordelaars in de tweede ronde, werd geëist dat zij goed geinformeerd waren over de te beoordelen patiënt, om geen systematische vertekening te laten ontstan tussen de eerste en tweede afname. Desondanks zou van enige vertekening sprake kunnen zijn. Zo wordt in enkele afdelingen van vijverdal het zgn. "mentor"-systeem gehanteerd, warbij personeelsleden als directe contactpersonen optreden voor een beperkt aantal patiënten. Deze mentoren waren vooral betrokken bij de invuliling van de vragenlijst in de eerste ronde, maar minder in de tweede. Indien deze mentoren werkelijk beter geInformeard waren dan de tweede beoordelaars zou van bias door verschil in informatie sprake kunnen zijn. De validitelt van da eerste beoordeling (de overeenkomst van het gescoorde gedrag en het werkelijke gedrag van de patient) zou dan beter zijn dan bij de tweede beoordeling.

Een ander verschil tussen de eerste en tweede afname bestond in de bekendheid met het instrument. In de eerste ronde had geen van de beoordelaars ervaring in het hanteren van de vol II. Het scoren van deze vragenlijst was voor ledereen even nileuw Bij de hertest daarentegen hadden 17 beoordelaars an de eerste ronde deelgenomen wat invloed kan hebben gehad op het scoringsgedrag. 
Voor de invuling war de VoL II is echter nawelijks toelichting of oefening vexeigt, zodat dit fenomeen de vergelijkbarheid van de test-hertest-scores weinig beinvloed zal hebben. Voor het landelijk onderzoek was dit overigens wan groot belang, omat het personeel van de betrokken instellingen (psychiatrische ziekenhuizen, centra voor psychiatrische dagbehandeling en beschermende woonvormen) voor de eerste keer met deze vragenlijst geconfronteerd zon worden.

Ex zijn verschillende mogelijkheden om de mate van overeenstemming tussen twee beoordelaars te meten. Voor nominale en ordinale gegeverus $z$ ljn de procenten-methode en Cohen "s kappa-methode het meest gangbaar.

Bif de procenten-methode wordt het aantal overeenstemmendo beoordelingen gedeeld door het totaal aantal paarsgewijze beoordelingen. Het resultat kan vervolgens als percentuele overeensteming worden uitgedrukt. Deze methode is eenvoudig en wordt veel gebrulkt (Giel \& Bogaaxts, 1980). Een nadeel is echtex dat niet gecorrigeerd wordt voor de toevalskans op overeenstemming (Schouten, 1985).

Een andere veel gebruikte mat voor de berekening van de mate van overeensteming is Kappa (Cohen, 1960). Deze methode corrigeert wel voor de overeensteming op basis van toevalskans.

Bij de berekening van de mate van overeenstemming tussen de testen hertest-beoordeling is uitgegaan van een ongewogen kappa. In geval van perfecte overeenstemming bereikt kappa de waarde $\mathbb{1}$, bij het ontbreken van overeenstemming is kappa gelijk aan 0 . Een negatleve kappa duldt op een overeenstemming die geringer is dan op basis van toeval verwacht kan worden. De grens voor een redelijke kappa-waarde wordt wel arbitrair op .40 gesteld (Koopmans e.a., 1982, De Jong, 1984). Van een goede overeenstemuing wordt wel gesproken bij warden van .60 en hoger "In het volgende overzicht is per item de mate van overeenstemming angegeven volgens de procentenmethode en Cohen's kappa. 
Tabe1 3: Test-hertest overeensteming van $\mathbb{1}$ : volgens procentenmethode en Cohen's kappa (ongewogen).

\begin{tabular}{|c|c|c|c|}
\hline index m if thents & minte ver & overeatastenting & 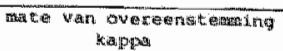 \\
\hline
\end{tabular}

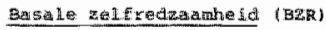

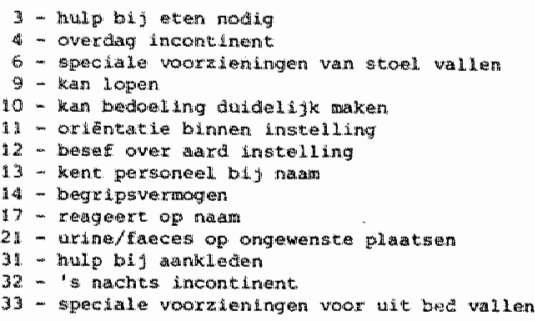

$\begin{array}{ll}91,6 & .55 \\ 79,2 & .45 \\ 95,9 & .48 \\ 97,8 & .65 \\ 96,4 & .50 \\ 89,2 & .65 \\ 79,6 & .55 \\ 92,5 & .78 \\ 86,3 & .46 \\ 99,2 & .25 \\ 61,9 & .35 \\ 85,8 & .70 \\ 84,6 & .57 \\ 97,3 & .72\end{array}$

Agreasivitteit (AGR)

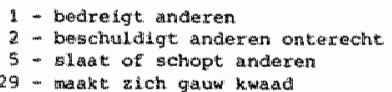

SuIcidalitait and

30 - dreigt met suficidie

39 - suld idepoging

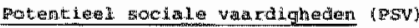

40 - if 3 tabt apenbaar vervoex te gebruiken.

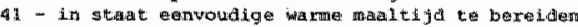

42 - In gtaat boodschappen te doen

43 - in stat op ta bellen

Interne sociala integratire (ISI)

15 - helpt op de afde1 ing

18 - zinwol bey ig buitury therapie

20 - oncla as thet een of ment bewoners

22 - ongev radad bewaners helpen

23 - gev's that helpen

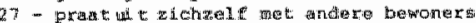

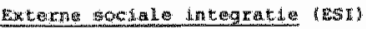

60,1

67,6

78,1

60,8

91,3

98,7
73,5

(2.5B

$72,3 \quad .53$

72,8
.28

55
45
48
65
50
65
55
78
46
25
35
70
57
72

79
67
49
34

.49

$+34$

- 31

. 33

. 59

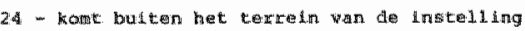

20 - mag de \$trazt op

4 A - telefonert zeli the anderen

45 - wordit opgebeld

46 - getrijte briteven/kasten

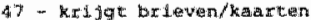

4 - gatis in de werek op bezoek

49 - blifte wekend bij anderen

50 - kri jut beroek

5 - gat

52 - bezoekt biosciopp, theater, concert, kerk

53: - doet the an ultstapjeg

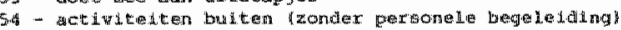

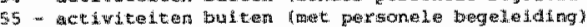

56. - bootschepera doen buten

57 - wertict bultan da instikling

se - 14est de krart

59 - 1 gest thischrifter

50 - kijkt televdisio

$6 \mathrm{l}$ - prat mot personed over gebeurtenissen butten
}

$\begin{array}{ll}73,0 & \\ 54,7 & 50 \\ 55,4 & -31 \\ 62,2 & -32 \\ 160,8 & -40 \\ 64,9 & -25\end{array}$

60,5

$75,8 \quad .46$

49,7 . 14

GE, O $\quad .43$

$95,9 \div 4$

66.2

$69,2+48$

81,1

$60,0 \quad-33$

$67,8 \quad .42$

40,8

$6 \%, 8+50$

$84,6 \quad .26$

$63,5 \quad 43$

47,3

$58,8+31$

$56,0 \quad .30$ 
Met uitzondering yan de PSV-index komen bij elk concept enkele items voor. warvoor een geringe mate van overeensteming biljkt te bestan bijl test-hertest.

Bij het concept "basale zelfredzaameld" vertonen 2 van de 14 items weinig consistent antwoordgedrag. Ook hadden drie van de 6 items van het concept "interne sociale integratie" lage kappawarden. Bij "externe sociale integratie" gold dit voor 8 van de 20 items. Bij alle vier items van het concept "potentiêl sociale vardigheden" bestond een redelijke tot goede mate van overeensteming tussen beoordelaars.

Aanzilenlijk minder goed waren de kappa"s voor de suicidaliteitsitems. Alhoewel de geobserveerde overeensteming met meer dan $90 \%$ groot was, vertoonden beide items betrekkelijk lage kappa-waarden. ook op twee van de vier agressie-items werd weinig consistent gescoord. De bevinding van Baas e.a. (1984) dat de verpleegkundigen bij het invullen van de BOP zich het meest zeker voelden bil het scoren van de agressiviteits-items hoeft dus niet te betekenen dat verpleegkundigen ook onderling in oordeel overeenstemmen.

Omdat in het landelijk onderzoek niet de indiwiduele items, mar de indices met gegroepeerde scores van belang waren, is vervolgens gekeken naar de test-hertest overeensteming op index-niveau. 
Tabel 4: Mate van test-hertest overeensteming op index-niveau: naar percentuele overeensteming en kappa.

\begin{tabular}{|c|c|c|}
\hline indices & $\begin{array}{l}\text { mate van } \\
\text { overeen- } \\
\text { stemming } \\
\text { : }\end{array}$ & $\begin{array}{c}\text { mate van } \\
\text { overeen- } \\
\text { stemming } \\
\text { Kappa }\end{array}$ \\
\hline $\begin{array}{l}\text { Easale zelfredzamheid }(0-2,3-5,6-11 \text {, } \\
12-28)\end{array}$ & 81,4 & 0.64 \\
\hline Agressiviteit $(0-1,2-3,4-8)$ & 59.2 & 0,33 \\
\hline $\begin{array}{l}\text { SuIcidaliteit }(0-1,2-3,4-6) \\
\text { Potentiè sociale vaardigheden }\end{array}$ & 96,6 & 0,27 \\
\hline$(0-1,2-3,4-6,7-8)$ & 68,0 & 0,55 \\
\hline Interne sociale integratie $(0-2,3-5,6-12)$ & 62,1 & 0,43 \\
\hline $\begin{array}{l}\text { Externe sociale integratie }(0-14,15-24 \text {, } \\
25-34,35-40)\end{array}$ & 63,3 & 0,45 \\
\hline
\end{tabular}

Naar aanleiding van bovenstaande tabel kan worden vastgesteld dat een viertal indices (BZR, PSV, ISI, ESI) ook na $\#$ drie maanden een redelijke tot goede mate van overeenstemming tussen hulpverLeners te zien geven. De agressiviteitsindex daarentegen is anzien $1 i j k$ minder betrouwbaar.

Met de sulcidaliteitsindex lijkt iets bijzonders aan de hand te zijn. Bijna $97 \%$ van de patiënten werden bij test-hertest door bedde beoordelaars in dezelfde groepen gescoord. Wel bestond deze gemeenschappelijkheid in oordeel vooral ten anzien van de zeer grote groep patiènten zonder suicideneigingen $(0-1)$. De intracategorie kappa voor deze groep was met 0,56 redelijk tot goed. De enkelle patiënten daarentegen warbij wel bij de eerste beoordeling suicideneigingen werden genoema, werden bif de tweede beoordeling bijna uitsluitend ingedeeld bij de eerste groep (0-1). De kappa-mat voor overeensteming binnen de tweede en derde categorie was zelfs gering negatief. 
Fen verklaring hiervoor is dat sulcidepogingen - die met een factor 2 sterker worden gewogen - alleen door enkele personen worden ondernomen, en dan ook nog slechts incidenteel. Een dergelijke dad zal zich - gelukkig - zelden in een periode van arie manden nog eerig herhalen, wat tot uiting komt in een geringe test-hertest-overeensteming woor deze groep.

\section{Het patiëntinterview (VOL III)}

De gemidalde dur (median) van een interview was 15 minuten, met een range tussen 5 tot 75 minuten. Het team van interviewers bestond uit 10 B-verpleegkundigen die bij de Rijksuniversiteit Limburg de studie geneeskunde of gezondheidswetenschappen volgen. De helft daarvan had interviewervaring door het vooxonderzoek. De vragendijst is zoveel mogelijk in een aparte ruimte afgenomen in afwezigheid van het personeel, om sociaal wenselijk antwoordgedrag naar behandelaars/verpleegkundigen toe zoveel mogelijk te voorkomen. Om practische afnameproblemen te voorkomen bijvoorbeeld bij lichamelijk op enigerlei wijze gehandicapte patiënten, is gekozen voor een afmameprocedure warbij een interviewer. naast de patiënt zittend, de vragen één voor één voorleest en tegelijk aan betrokkene laat zien. De patiënt koos vervolgens én van de vier antwoordmogelijk kheden (verbaal of door aamijzen) en deze werd door de interviewer aangekruist.

Met de formulering van de vragen hadden de patiënten weinig problemen. Een uitzondexing hierop vormde vraag 9 . Deze vraag over werken buiten het psychiatrisch ziekenhuis werd door 18\% van de respondenten niet beantwoord. Uit de toelichting van de interviewers op het ewaluatieformulier bleek dat met name bejarade patienten. maar ook enkele patiënten met werk buiten de instelling deze vraag niet relevant vonden.

Bij ongeveer $80 \%$ van de patiënten verliepen de interviews zonder al te veel problemen. De interviewers hadden geen of alleen positieve kanttekeningen over het gesprek. Bij de overige 208 van de gesprekken werden wel storende omstandigheden genoemd. De meeste opmerkingen hadden betrekking op handicaps van patienten 
zoals: hardhorendheid en doofheld $(4 x)$; afaie $(3 x)$ of ondulde$1 \mathrm{ijk}$ praten $(3 \mathrm{x})$; geringe intelligentie (4x); niet kunnen lezen $(3 x)$ omat men blind was of de bril voor het interview was vergeten; bedlegerigheid $(2 x)$; verwardheld kort na een psychotische fase $(5 x)$. Sommige patienten waren zeer breedsprakig $(6 x)$ en gingen weinlig op de vragen zelf in, terwijl er ook patièten waren die in zichzelf gekeerd waren $(3 x)$ en warbij het soms pas na langdurig vragen en herformuleren mogelijk was om hun even antwoord te ontfutselen. Enkele patienten (4x) waren buitenlanders en beheersten de Nederlandse taal niet of slechts gedeelte$1 \mathrm{ijk}$.

De wens om het gesprek te houden in een aparte ruinte kan niet altijd worden gehonoreerd. Doordat enkele patienten zich slecht konden verplaatsen, werden een aantal interviews $(2 x)$ in het kantoor of dagverbliff gehouden. Ook enkele patienten die te onrustig of te verward waren. werden in het dagverblijf geinterviewd, - één patiënt zelfs in de gang voor de isoleerruimte. Drie patiënten waren buitenlanders en hadden talkundige problemen bij het begrijpen en beantwoorden van de vragen.

Alhoewel de interviewers niet bij de patient bekend waren, toonden de patiënten vaak veel vertrouwen en beantwoordden de vragen openhartig. Na afloop van het gesprek meenden de interviewers dat $67 \%$ spontaan op de vragen antwoordde, $70 \%$ als beslist overlkwam en 85: betrokken was bij het interview. Van de patiènten was $75 \%$ rustig en vriendelijk.

Maar er waren ook patiënten die het interview als bedreigend hebben ervaren. Vijf patiẻnten vertelden dit an de interviewer. Bij andere patiënten kwam dit volgens de interviewer tot uiting in sterke orkekerheid ("ik weet niet wat ik zelf wil of nilet wil" $(2 x)$ en emoties zoals huilen $(2 x)$ of wegloopneigingen ( $5 x)$. om een indruk te geven, voor welke problemen de intervitewers in enkele gevalien stonden, volgt hierna een korte bloemlezing uit de evaluatieverslagen: 
- "bewoonster begon mij telkens na het stellen van én of twee vragen na te zeggen of begon te $z$ ingen. Naarmate het interview langer durde, werd het nazeggen of zingen langduriger, totat zij helemal "opging in het gezang" en ik bij vraag 17 het interview moest afbreken. Waarschijnlijk ervoer bewoonster de vragen als (te) bedreigend en was dit een afweermechamisme van hase"

- "mevrouw had een duidelijke handicap met spreken (afasie), maar we zijn ex kalmpjes aan "wrij goed" uitgekomen (40 minuten)";

- "deze vrouw wilde de interviewlijst zelf invullen in de huiskamer; anders deed ze niet mee. Ik zat er wel bij en we zaten een beetje apart" "

- "patiente was 82, heeft een heel leven geleefd: wilde elgenlijk alleen nog maar rustig sterven, het liefst zo snel mogelijk";

- "liep na vraag $20 \mathrm{weg}$. Was het "zat". Makte zich nogal kwaad, kwam later alsnog binnem on het interview af te maken (na een half wur)";

- "bewoner ils blind, maar kon wel goed de vragen beantwoorden";

- "mevrouw werd agressief naar mij toe en stapte daarna op. IK was door het afdelingshoofd er al op gewezen, dat deze kans er dik in zat";

- "meneer is Duitser en kon zodoende geen Nederlandse tekst lezen. Wel gaf hij mij de antwoorden in behoorlijk Nederlands";

- "mevrouw was enorm in zichzelf gekeerd en antwoordde bijna niets. Ik dacht ook dat ze zich met name bij andere woonsituaties weinig voor kon stellen. De communicatie ging vaak uitsluitend via ja - of nee - knikken".

9.1. Index "Houding Ontslag" (H.O.) en "Houding Instelling/Afdeling ${ }^{\prime \prime}$ (H.I.)

Hoe werd nu op basis van scores op de enkelvoudige items een schatting verkregen van de houding van patiënten ten aanzien van ontslag en de afdeling of instelling? 
De vragen over de houding ten aanzien van ontslag en instelling hebben ieder 4 antwoordcategorieën, variërend van zeer negatief, negatief, positief tot zeer positief. Aan het antwoord waaruit een zeer negatieve houding $t . a \cdot v$. ontslag blijkt, wera de waarde 1 toegekend, aan een antwoord met een niet zo sterke negatieve connotatie de warde 2 , tot tenslotte de warde 4 voor een antwoord dat een zeer positieve ontslaghouding impliceert. Als voorbeeld volgt hieronder vraag 7 :

vraag $7:$

Zou $U$ met de nodige hulp zelfstandig willen wonen?

categarie:

\begin{tabular}{lccc}
\hline zeker & warschijnijjk & warschijnlijk & zeker \\
niet & niet & wel & wel \\
\hline
\end{tabular}

score:

$\mathbb{1}$

2

3

4

Alleen voor de patiënten die ook bij doorvragen niet uit de vier antwoordmogelijkheden konden kiezen was een codering "geen antwoord/weet niet" gereserveerd. Als een vraag niet van toepassing was, moest dit apart op de lijst worden vermeld.

Per patiënt werd vervolgens apart over de vragen ten aanzien van ontslag respectievelijk instelling een somscore berekend. Alleen voor patiënten die meer dan 80 \& van de vragen inhoudelijk hadden beantwoord, werd de somscore gedeeld door het aantal beantwoorde vragen, wandoor een gestandaralseerde index-score werd verkregen. Deze indexscore varieert van 1,00 (uiterst negatief) tot 4,00 uiterst positief. Voor de presentatie van de uitkonsten werd gekozen voor een onderverdeling van de scores naar drie groepen, $t . w .:$

- negatieve houding: indexscore $1,00 \mathrm{t} / \mathrm{m} 1,99$

- ambivalente houding: indexscore $2,00 t / m 2,99$

- positileve houding: indexscore $3,00 \mathrm{t} / \mathrm{m} 4,00$ 


\subsection{Yaliditeit}

De homogeniteitscoéfficiënt voor de H.0.-index was met . 84 betrekkelijk hoog en werd berekend bij 201 patiènten waarvoor alle 10 antwoorden beschikbaar waren. De desbetreffende coëfficiênt voor de H.I.-1ndex was .88 .

De vraag is nu, of de $\mathbb{H} .0$. -index voldoende aan zijn uiteindelijke doel beantwoordt, namelijk het meten van "houding ten aanzien van ontalag" en niet van een andere factor zoals bijvoorbeeld "optimisme". Een index of test is valide of geldig, naarmate de index het verschijnsel meet, warvan verondersteld wordt dat hij die meet.

Het is echter niet eenvoudig om een geschikt extern criterium te vinden, warop de index-score op geldigheid kan worden getoetst. De patiënt alleen lijkt de deskundige en de bij uitstek geschikte bron van informatie te zijn, als het gat om zijn/haar houding ten aanzien van ontslag. Zo concluderen Shadish e.a. (1985) naar aanleiaing van onderzoek over opvattingen van patiënten en personeelsleden over zorgaspecten binnen en buiten "psychiatrische verpleeghuizen"; "one cannot assume that the patients own interests will be adequately reflected by other interest groups; if the patients interests are the issue, the patients must be a.sked" .

ondanks deze kanttekening is toch een poging ondernomen om een indruk te krijgen over de geldigheld van de patiëntinformatie. Als een "next-best"-bron van informatie kan de hoofdbehandelaar of de verpleegkundige worden beschouwd die betrokkene goed kent. Hun taxatie wan de ontslagbereidheld van de patiënt zou dan als extern referentiecriterium kunnen dienen. Drenth (1975) spreekt. in dit verband van "concurrent validity", warbij beoordeeld wordt, hoezer de resultaten corresponderem met gelijktijaig beschikbare criteriungegevens. Als voorbeeld noemt Drenth het valideren van een test door de testresultaten van patienten te vergelifken met aanpassingsbeoordelingen van behandelende psychiaters. 
In dit onderzoek was een oordeel beschikbaar van zowel de behandelend psychiatex als de verpleegkundige. Door beiden werd een ja- of nee-antwoord gegeven op de vraag: is betrokkene naar vw mening bereid toe te werken nar ontslag?

Een belangrijke en te toetsen anname daarbij is dat de psychiater en de verpleegkundige de ontslaghouding van de patient goed kunnen inschatten. Als controle op deze veronderstelling zullen de taxaties van hoofdbehandelaar en verpleegkundige op patientniveau met elkaar worden vergeleken (tabel 5). Indlen het oordeel van psychiater en verpleegkundige consistent is, kan redelijkerwijs worden aangenomen dat het overeenstemmende oordeel van deze deskundigen een redelijke mat is voor de bepaling van de "concurrent validity". In de volgende tabel komt dit aspect an de orde.

Tabel 5: Mate van overeenstemming tussen psychiater en verpleegkundige in het oordeel over de ontslagbereidheid van de geinterviewde patienten.

verpleeg-
psy- jundige
chiater
ja $37(50,08)$ $23(12,88)$ $60 \quad(23,68)$

nee $37 \quad(50,08)$ $157(87,29)$ $194(76,48)$ 
Hu blijkt uit bovenstaande tabel dat tussen beide beoordelaars esen grotere mate wan overeensteming bestat over de patienten die niet met ontslag willen gaan, dan over patiënten die wel ontslagen willen worden. Van de 180 geinterviewde patiënten die volgens de verpleegkundige niet gemotiveerd waren voox ontslag, gaf de psychiater in 157 gevalien hetzelfde oordeel (87\%). Veel minder overeensteming bestond over de patienten die wel naar ontslag toe willen werken. Alleen voor de helft (508) van de patiënten $(N=74)$ die in dit verband door de verpleegkundige werden genoemd, gaf de psychlater eenzelfde oordeel. De schatting van een negatjeve ontslaghouding is dus aanzienlijk stabieler en warschijnlijk ook exacter, dan de taxatie van een positieve ontslaghouding. Het is mogelijk dat dit consequenties heeft voor het bepalen van geldigheid (validiteit) van positieve index-score's.

Vervolgens is nagegaan in hoeverre het oordeel van de hoofdbehandelaar of verpleegkundige correspondeerde met het bovenste en onderste kwartiel van de H.O.-index-scores. Als de positieve inschatting van het personeel overeenkomt met een grote ontslaggeneigdheid van de patiënt, en een negatieve inschatting met eren geringe ontslaggeneigdheid, dan kan de index als voldoende valide worden beschouwd om er verder mee te werken. In de tabellen 6 en 7 zijn de kwartielscores van de VoL III gekoppeld aan het oordeel van psychiater respectievelijk verpleegkundige. 
Tabel 6: mate van overeenstemming tussen oordeel psychiater en antwoord patiënten (kwartielscore 1.0. -index) wat betreft houding $t \cdot a \cdot v \cdot$ ontslag.

\begin{tabular}{|c|c|c|}
\hline psychiater & $\begin{array}{c}\text { ja } \\
\text { indexsc } * 3,2\end{array}$ & $\begin{array}{c}\text { nee } \\
\text { indexsc. } \leq 1,9\end{array}$ \\
\hline ja & $39 \quad(52,08)$ & $7 \quad(10,68)$ \\
\hline nee & $36 \quad(48,08)$ & $59 \quad(89,48)$ \\
\hline totaal & $75(100,08)$ & $66(100,08)$ \\
\hline
\end{tabular}

Tabel 7: mate van overeensteming tussen oordeel verpleegkundige en antwoord patienten (kwartielscore H.0.-index) wat betreft houding $t$.a.v. ontslag.

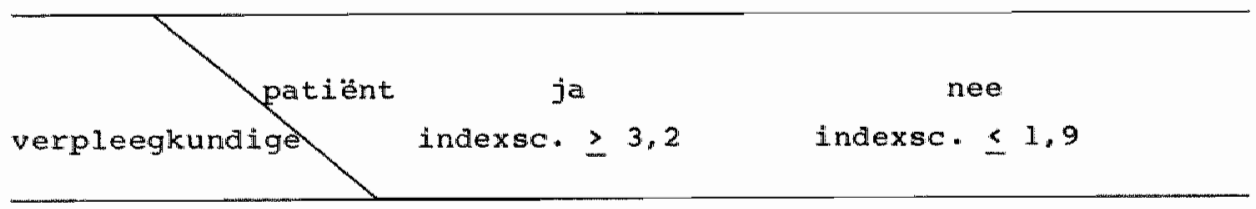

Ja

$27 \quad(35,58)$

$6 \quad(8,78)$

nee

$49(64,58)$

$63(91,3$ 䊈)

totaal

$76(100,08)$

$69(100,08)$ 
In de tabelien 6 en 7 valt op dat een lage kwartielscore, het niet met ontslag willen, sterk corxespondeert met het desbetreffende antwoord van de psychiater (89:) als ook met dat van de verpleegkundige (9lif). Veel minder groot is de overeensteming, als de hoge kwartiellscores van de H.O.-index, het wel met ontslag willen, worden vergeleken met het respectievelijke oordeel van de hulpverleners. Van de 75 patiënten die hoog op de index scoren was volgens het oordeel van de psychilater $52 \%$ geneigd om naar ontslag toe te werken (tabel 6). Naar het oordeel van de verpleegkundige was deze proportie met $35 \%$ nog kleiner (tabel 7). Het lijkt dus alsof de index een goede afspiegeling geeft van de wens om in de instelling te blijven, en een minder goede indruk van de wens om met ontslag te gaan. Wat betreft het laatste $z i j n$ er a anwijzingen dat niet de index, maar het externe criterium onnauwkeurig meet (tabel 5), vooral als het gat on het oordeel. van de verpleegkundige. 
DEEL III - STEEKPROEFTREKKING

\section{Steekproeftrekking}

Bij de selectie van doelgroeppersonen voor dit onderzoek wera gebruik gemaakt van de methode van zgn. twee traps random steekproeftrekking. Eerst werden bij toeval gekozen instellingen benaderd om deel te nemen aan het onderzoek, waarna binnen de deelmemende instelingen vervolgens een aselecte steekproef van bewoners/patiënten is getrokken. Omdat de witvoeringsdetails op enkele belangrijke punten verschillen, zullen de procedures per voorzieningensector apart besproken worden.

10.1. Steekproeftrekking bij de algemene psychiatrische ziekenhuizen

De lang opgenomen patiënten van 38 algemene psychiatrische ziekenhuizen werden beschouwd als de populatie waaruit een steekproef getrokken diende te worden. Naar schatting verbleven eind december 1983 10.300 patiënten lang in deze instellingen volgens de in dit onderzoek gehanteerde definitie. Als bron voor deze schatting diende de Patiëntenregistratie Intramurale Geestelijke Gezondheidszorg (GHIGV).

Bij de bepaling van de grootte van de steekproef was er van uitgegaan dat de patiënten die binnen de steekproef vallen niet van de landelijke populatie van lang opgenomen patëutun mochten verschilien wat betreft de spreiding ower enkele belangrijke kenmerken zoals geslacht, leeftija, verblijfsduur en burgerlijke staat. De variabele met de grootste spreliding (s), samen met het gekozen betrouwbaarheidsinterval en de daarmee samenhangende warde voor de afstand tat het gemiddelde $(z)$ en de mate van exactheid (e) voor de schatting van het populatie-gemiddelde wordt vak gebruikt om de omvang van de ateekproef te bepalen. De Patiëntenregistratie Intramurale Geestelijke Gezondheldszorg bood een goede mogelijkheid om de populatieparameters "gemiddel- 
de" en "spreiding" ( $X$ resp. s) te bepalen. Vitgaande van gegevens over 1980 (GHIGV, 1983) bleek dat de variabele leeftija de grootste spreiding $(s=17)$ rondom de gemiddelde wadrde $(x=52)$ vertoonde. (4) Wordt ex nu van uitgegan dat de gemidalde leeftijd binmen de steekproef zowel nar boven als naar beneden met twee jaar mag verschillen van het populatiegemiddelde, en wordt tevens uitgegaan wan een betrouwbarheidsinterval van $95 \%$, an kan de formule $e=\mathrm{z} \times \frac{\mathrm{s}}{\sqrt{\mathrm{n}}}$ (Blalock, 1960, p. 166) als volgt ingevuld worden: $2=1,96 \times \frac{17}{\sqrt{n}}$, waaruit volgt $n=278$

Ondat bij twee traps steekproeftrekking meer kans bestaat op fouten door de manier van steekproeftrekken, is het een goede gewoonte (zie scheuch, 1974, p. 39) on de steekproeforvang door wermenigvuldiging met de factor $\sqrt{2}$ te vergroten. Deze correctiefactor betekende voor de steekproefomvang een aanvuliing tot 393 . afgexond tot 400 personen. Rekening houdend met een non-respons percentage van $30 \%$ werd bij de uiteindelijke steekproef gerekend op ca. 600 lang opgenomen patiènten van algemene psychiatrische ziekenhuizen.

Uitgaande van dit gegeven was vervolgens de vraag, in hoeveel instellingen deze steekproef getrokken moest worden. Dit aantal instellingen mocht niet te klein zijn on instellingsgebonden vertekening van de steekproef te voorkomen, anderzijds mocht dit aantal ook niet te groot zijn om de uitvoerbaarheid van het onderzoek binnen het gegeven budget en tijasbestek (een periode van twee jaar) niet in gevaar te brengen. Deze afweging heeft geresulteer in de keuze voor een aatal van vijf psychiatrische ziekenhuizen, ofwel 120 steekproefpatiënten in elk van deze instelingen.

Ex is overleg geweest met in totaal acht aselect gekozen algemene psychiatrische ziekenhuizen. In vijf van de acht instellingen hebben de informatief-oriënterende besprekingen tussen directie. 
en onderzoekers geresulteerd in deelname aan het onderzoek. De vijf instellingen zijn verdeeld over vier provincies, $t . w$. Noord-Holland, Zuid-Holland, Gelderland en Limburg. Een instelling is gevestigd in een stad met meer dan 100.000 inwoners de overige vier instellingen hebben hun locatie in een gemeente met $20-<50.000$ inwoners. Van de 5 instellingen hebben vier een opnametraditie die meer dan een halve eeuw bestrijkt terwijl éen instelling in het begin van de 70-er jaren patienten 13 gaan opnemen.

In het volgende overzicht $z i j n$ de an het onderzoek deelmemende algemene psychiatrische ziekenhuizen op enkele kenmerken vergeleken met het total van instellingen.

Tabel 8: Vergelijking van de 5 steekproefinstelingen met de algemene psychiatrische ziekenhuizen waarbinnen de steekproef is getrokken, naar gemiddelde grootte en doorstroming.

\begin{tabular}{|c|c|c|}
\hline 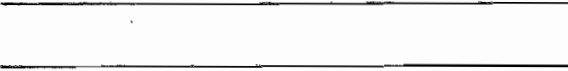 & $\begin{array}{c}\text { APZ-en totaal } \\
\mathbb{N}=3.7\end{array}$ & $\begin{array}{l}\text { Deelnemers } \\
\mathrm{N}=5\end{array}$ \\
\hline $\begin{array}{l}\text { Gemiddeld aantal bezette } \\
\text { bedden per } 31 / 12 / 84\end{array}$ & 547 & 650 \\
\hline $\begin{array}{l}\text { Opnameratio in de periode } \\
\operatorname{van} 1 \text { jan* }-31 \text { dec. } 1984 \text { * }\end{array}$ & 116 & 91 \\
\hline $\begin{array}{l}\text { Ontslagratio in de periode } \\
\text { van } 1 \text { jan. - } 31 \text { dec. } 1984 * *\end{array}$ & 111 & 84 \\
\hline $\begin{array}{l}\text { Longstayproportie t.o.v. } \\
\text { gemidd. aantal bezette bedden } \\
\text { (bestandspatienten langer dan } \\
\text { i jaar opgenomen). }\end{array}$ & 65,88 & 71.98 \\
\hline
\end{tabular}

\section{Bron: Enquête Jaarcijfers Psy- chiatrie 1.984, GHIGV, afd. onclerzoek}

* aantal opnemingen gedeeld door gemiddeld aantal bezette bedden op $31 / 12 / 84 \times 100$

* aantal ontslagen (excl. overledenen) gedeela door gemidald aantal bezette bedden op $31 / 12 / 84 \times 100$ 
zowel wat betreft de doorstroming van de instelingen gemeten in de vorm van opnameratio, ontslagratio en long-stay-proportie, als ook in de gemidalde capaciteit, verschilden de 5 deelnemende instelingen enigszins ten opzichte van de landelijke situatie. De delnemende algemene paychiatrische ziekenhuizen hadden gemiddeld meer patienten (= bezette bedden) en een geringere doorstroming das verwacht mocht worden op basis van het landelijk totaal. Redelijkerwijs mag worden verondersteld dat dergelijke verschillen op instellingsniveau niet de representativiteit van de patiëntensteekproef hebben vertekend.

\subsubsection{Uitvoeringsprocedures}

Madat de instelling toesteming voor deelname an het onderzoek had verleend, vonden tussen onderzoekers en de respectievelijke medische administraties besprekingen plats ortrent de organisatie van het databestand en de methode wan steekproeftrekking. Deze steekproeftrekking werd in alle 5 de instellingen door de onderzokers samen met de medische administraties uitgevoerd en omvatte globaal de volgende stappen:

- eerst werden patiënten met de diagnosen imbecilitas, idiotie en dementie buiten het steekproefkader geplatst;

- vervolgens de andere patiënten van het totale patiëntenbestand die niet aan één van de doelgroepdefinities voldeden.

De voor het creẻren van het steekproefkader benodigde verblijfsduurgegevens waren veelal niet centraal binnen de instelling beschikbaar en niet geheel volledig, wardoor de administraties van de afdelingen of paviljoenen zelf bezocht moesten worden. De bepalling van de verblijfsurgroepen was gecompliceerd doordat voorafgaande opmames in andere psychiatrische instelingen ook meetelden. Indien de verbliffsduur ook niet op afdelingsniveau te bepalen was, werd de betreffende patiënt uit het steekproefkader weggelaten, mar dit kwam zelden voor.

Indien het resterende bestand de 120 overschreed (in een enkel geval was dit niet $\mathrm{zol}$, werd hieruit een aselecte steekproef van 120 patiënten getrokken. 
Voar de uitwoering van het onderzoek en de verwerking van de gegevens werd een procedure gevolgd, warbij de mamen van de patienten niet bij de onderzoekers bekend waren. Slechts de eerder willekeurig toegekende patiëntnummers waren beschikbaar om de gegevens van de vol $I$, II en III te kunnen combineren. De koppeling tussen nummers en namen vond plats op de afdeling.

Aan iedere patiënt die binnen de steekproef viel, werd door een personeelslid van de afdeling toesteming gevraagd voor de afname van de VOL III, het patiëntinterview, nadat de patient eerst een uitnodiging daartoe had ontvangen en een beknopte schriftelijke toelichting op het onderzoek. On tot een optimale respons te komen werden de patiënten die om uiteenlopende redenen niet wilden deelnemen aan een dergelijk interview, nogmaals, en in een enkel geval tweemal, benaderd. Dit geschiedde alleen, indien het behandelend personeel op de betreffende afdeling hiervoor toestemming verleende.

\subsubsection{Respons}

Daar één van de deelnemende algemene psychiatrische ziekenhuizen aanzienlijk minder lang opgenomen patienten ( 1.0. p.) had dan de 120 warvan bij de steekproeftrekking binnen de insteliling werd ulitgegaan, was de toevalssteekproef nilet 600 patienten, maar 539. Bij controle achteraf aan de hand van de vol I bleek verder dat 27 patienten niet aan de doelgroepomschrijving woldeden, namelijk 12 patienten vanwege de diagnose dementie en 15 patienten vanwege een kortere verblijfsduur. De gecorrigeerde steekproef bestond dus uit 512 patiènten. In me 1984 werd met de gegevensverzameling gestart. Deze duurde tot augustus 1985 .

In het eerste contact met het afdelingspersoneel bleek dat enkele van deze patiënten niet meer voor een gesprek benaderd konden worden. Tussen deze stap in het onderzoek en het bepalen van de steekproef lag namelijk soms een periode van enkele maanden warin inmidaels: 
- 17 patiènten waren ontslagen of overgeplaatst naar andere ggz-vooxzleningen;

- 4 patichten waren overleden: en

- 1 patiént was opgenomen in een algemeen ziekenhuis.

Voor deze patiënten werd wel gevraagd om alsnog de VoI I en VOL II in te vulien, mar kon geen interview (VOL III) plaatsvinden. Aan het einde van deze periode was voor $748(\mathrm{~N}=381)$ van de patienten zowel de VOL I als de VOL II ingevuld en geretourneerd. Voor $60 \%$ ( $H=306)$ waren alle drie vragenlijsten beschikbaar.

Tabel 9: Responsoverzicht naar verblijfsduurgroep; algemene psychiatrische ziekenhuizen.

\begin{tabular}{|c|c|c|c|}
\hline & steekproef: & $\begin{array}{l}\text { waarvan voL I } \\
\text { beschikbaar }\end{array}$ & $\begin{array}{l}\text { warvan Vol I \& II } \\
\text { beschikbaar }\end{array}$ \\
\hline groep $z \cdot 1.0 \cdot p$ & $310(100,08)$ & $305(98,4)$ & $248 \quad(80,0)$ \\
\hline groep $1 \cdot 0 \cdot p \cdot-c$ & $110(200,08)$ & $104(94,5)$ & $91(82,7)$ \\
\hline groep 1.0.p.-dc. & $92(100,08)$ & $66(71,7)$ & $42(45,7)$ \\
\hline totaa 1 & $512(100,08)$ & $475 \quad(92,8)$ & $381(74,4)$ \\
\hline
\end{tabular}

Uit bovenstaand overzloht blijkt dat de gegevens voor de groep lang en alscontinu opgenomen patiënten (1.0.p.-dc.) het minst volledig waren. Een aantal personen $(N=9)$ was op het tijastip van het interview ontslagen, terwijl daarnaast betrekkelijk veel. patiënten ( $\mathrm{N}=31$ ) weigerden om aan het vraaggesprek (VOL III) deel te nemen, wat consequenties had voor de invulling van de voL $I$ en VOI II door de hulpverleners.

Bij de andere verbiljfsduurgroepen kon, met meer dan $80 \%$ op de VOL I \& II, gesproken worken van een hoge respons. In de verdere hoofdstukken wordt uitgegaan van de gegevens van de 381 patiènten warvoor de VOL I en VOL II is ingevuld. De gegevens over de houding van de patiënt hebben betrekking op 287 patiënten waarbij het $\mathbb{i n t e r v i e w}$ (VOL III) in $z^{\prime} n$ geheel kon worden afgenomen. 


\subsubsection{Representativiteit}

Steekproefonderzoek wordt met de intentie verricht om de resultaten ook van toepassing te verklaren op de grote groep van personen die wel aan de doelgroepomschrijving voldoet, maar nitet heeft deelgenomen aan het onderzoek. Dit onderzoek vormt hierop geen uitzondering.

Een belangrijke voorwarde voor een dergelijke verbreding van het generalisatiebereik is, dat de responsgroep zoveel mogelijk een natuurgetrouwe afspiegeling vormt van de samensteling (verdeling kenmerken) van de populatie, en voldoende groot is om ook voor essentiële subgroepen (bv. lang mar discontinu opgenomen patiennten, bejaarden, vrouwen, patiënten met goede respectievelijk slechte A.D.L.-functies) betrouwbare uitspraken te genereren. De Patiëntenregistratie Intramurale Geestelijke Gezondhesdszorg (PIGG) kan ten aanzien van een drietal vragen waardevolle informatie verstrekken, namelijk:

(a) hoe groot is de responsproportie per verblijfsduurgroep?

(b) in hoeverre heeft de aselecte steekproeftrekking daadwerkelijk geleid tot een representatieve verdeling van steekproefpatienten ten opzichte van de landelijke populatie?

(c) in hoeverre heeft selectieve non-respons geleid tot een. niet-representatieve verdeling van de responsgroep, dit zowel ten opzichte van de steekproef als ten opzichte van de landelijke populatie?

voordat op deze vragen wordt ingegaan, volgen eerst enkele kanttekeningen vooraf.

Het antal variabelen, warop de representativiteit van de steekproef kon worden vergeleken, beperkte zich tot de variabelen die zowel in het onderzoek als de PIGG werden verzameld. Het ging daraij om de volgende variabelen: geslacht, leeftijd, burgerlijke staat, juriaische situatie en psychiatrische diagnose.

Voor twee van de arie in het onderzoek onderscheiden verblijfsduurgroepen (te weten continu 2-5 jaar opgenomen en langer dan 5 jaar opgenomen) waren corresponderende landelijke cijfers van de PIGG beschikbaar. Voor lieder van deze twee graepen wera dan ook 
de representativiteit vergeleken ten aanzien van bovengenoemde wije variabelen (tabelien 10 en 11).

De cijfers van de PIGG en van de steekproef waren overigens niet geheel synchroon. De gegevens wan de PIGG hadden betrekking op de aanwezige patienten op 31 december 1983, terwijl in december 1984 bij de 5 psychiatrische ziekenhuizen ongeveer de helft van de steekproefgegevens was verzameld. Tussen de steekproef- en de landelijkke gegevens bestaat dus een verschil van ca. één jaar. Voor een tweetal varlabelen zijn de verschillen in tijdstip van registratie groter. Zo zijn de gegevens over de burgerlijke staat en psychiatrische diagnose in de PIGG na de opname niet muteerbaar. Gedurende het verblijf van de patient in de instelling worden deze gegevens niet meer aangepast aan niewwe ontwikkelingen. Dat zou met name voor de zeer llang opgenomen patiënten kunnen betekenen, dat de gegevens van de steekproef waarin van de actuele diagnose wordt uitgegaan en de gegevens van de landelijke populatie op dit aspect niet vergelijkbaar zijn. Gelukkig heeft eind 1978, met de wijziging van het registratiesysteem, een "actualisering" van het totale gegevensbestand plaatsgevonden, waarbij ook de gegevens over de burgerlijke staat en de psychiatrische diagnose an de actuele situatie zijn aangepast. Van de langverblijwende patiënten (31-12-1983) is het echter niet bekend, welke wijzigingen na 1978 in burgerlijke staat en psychiatrische diagnose zijn opgetreden. 
Pabel 10: Vergelijking van de steekproef van lang opgenomen patiënten $(2-5$ jaar $)$ met de desbetreffende landelijke populatie in algemene psychiatrische ziekenhuizen (31-12-1983); naar geslacht, leeftija, burgerlijke staat, juridische situatie en psychiatrische diagnose.

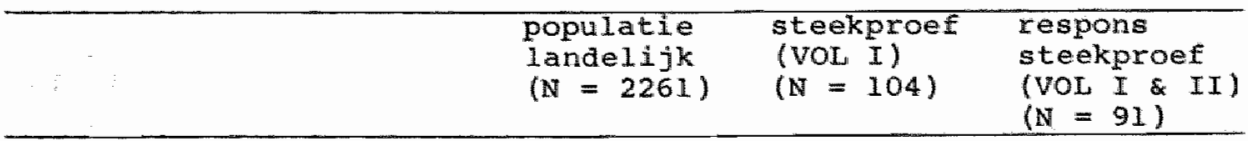

\section{gesilacht}

man

vrouw

leeftijd

25 jaar
$25-34$ jaar
$35-44$ jaar
$45-54$ jaar
$55-64$ jaar
$65-74$ jaar
$\geq 75$ jaar

burgerlijke staat

ongehuwd

gehuwd

gescheiden

weduwstaat

juridische situatie

vrijwillig

in bewaringstelling

rechterlijke machtiging

strafrechterlijke maatregel.

psychiatrische diagnose

\section{dementie}

andere organische

psychische stoornis

schizofrenie

affectieve psychose

andere niet organische

psychose

neurose/depressie

persoonlijkheidsstoornis

alcohol drugs

zwakz linnigheid ( 1 icht)

overige psychische stoornissen
50,98

49,1

4,3

18,0

14,7

16,5

18,1

16,9

11,4

50,9

22,5

13,3

13,3

90,6

1,1

8,0

0,3

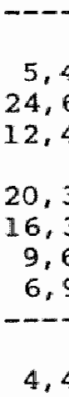

51,5 q

48,5

$50,5 \%$

49,5

3,0
13,9
25,7
15,8
14,9
19,8
7,0

3,3

11,0

25,3 *

16,5

16,5

19,8

7,7

50,5

48,4

17,8

19,8

18,7

20,9

11,9

$12,1$.

$\begin{array}{rr}95,0 & 95,6 \\ -5,0 & -1,4 \\ ---0 & --5\end{array}$

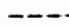

$-\cdots$

7,9

8,8

35,6 *

5,9

33,0

6,6

$7,9 *$

$6,6 *$

19,8

20,9

13,9

15,4

3,0

3,3

4,0

4,4

2,0

1,1

* het aantal patienten binnen de steekproef ( $\left.\mathbb{N}_{i}\right)$ is groter of kleiner dan $N_{i} \pm 2 \sqrt{N}_{i}$, waarbij $N_{i}=$ verwacht aantal patiënten per cel op basis van de verdeling van de variabelen in de populatie (Reid, 1960). 
Tabe1 11: Vergelijking van de steekproef van zeer lang opgenomen patienten ( 5 jaar) met de desbetreffende landelijke populatie in algemene psychiatrische ziekenhuizen (31-12-1983); naar geslacht, leeftijd, burger 1 ijke staat, juridische situatie en psychiatrische diagnose.

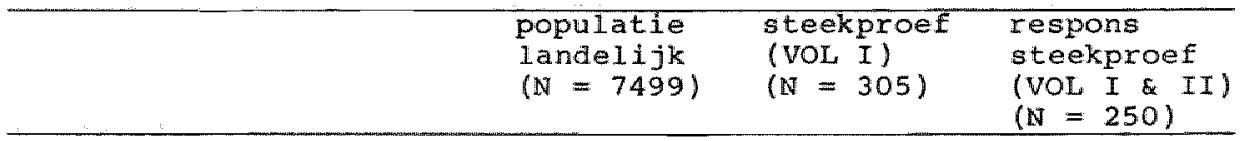

gesiacht

man

vrouw

leeftija

\begin{aligned} \hline 625 & Jaax \\ $25-34 &$ jaar \\ $35-44 &$ jaar \\ $45-54 &$ jaar \\ $55-64 &$ jaar \\ $65-74 &$ jaar \\ 775 & jaar \end{aligned}

burgerlijke staat

ongehuwd
gehuwd
gescheiden.
weduwstat

juriaische situatie

Vrijwillig

rechterlijke machtiging

strafrechterlijke matregel

psychiatrische diagnose

\section{dementie}

andere organische

poychisohe stoornis

whizofrenie

affectleve psychose

andere niet organische

psychose

neurose/depressie

persoonl $i j k$ he 1 as stoorms

alcohol arugs

zwakzinnigheid (11cht)

overige psychische stoor-

nissen

\section{9,48}

50,6

0,2

4,9

9,7

15,9

23,8

23,8

21,8

73,6
12,2
6,8
7,5

96,6

0,3

3,1

0,1

0,3

4,7

10,7

18,7

25,4

19,4

20,7

75,6

9,0

9,0

6,4

52,8 훙

47,2

0. 4

4,0

10,5

19,8

26,2

19,4

19,8

75,0

9,3

9.7

6. 0

98,0

98,4

$---$

$---$

1. 6

$-m-$

$--m$

7,9

58,8

5,9

5,7

57,8

5,4

4.9

58,9

4,5

7,2

5,7

5,7

5,3

10,7

7,1

7,7

6,8 *

6,5

2,7

2,8

7. 4

7,3

1,5

1,4

1,6

ile voetnoot vorige pagina. 
ad a: hoe groot is de responsproportie per verblijfsduurgroep?

Voor ongeveer $3,38(N=250)$ van alle zeer lang opgenomen patien$\operatorname{ten}(\mathrm{z} .1 .0 . \mathrm{p})$ en $4,0 \%(\mathrm{~N}=91)$ van de lang en continu opgenomen patiënten $(1.0 . \mathrm{p} .-\mathrm{c}$ ) in psychiatrische ziekenhuizen wera geaurende het onderzoek zowel de vol I als de vol II ingevula. Bif gebrek aan landelijke gegevens is niet bekend, hoe groot het aandeel is voor de derde verblijfsduurgroep (1.0.p.-dc.).

ad b: in hoeverre heeft de steekproeftrekking geleid tot een representatieve verdeling $\operatorname{van}$ steekproefpatienten ten opzichte van de landelijke populatie?

Voor 988 respectievelijk $94 \%$ van de steekproefpatienten $(z .1 .0 . p$. en 1.o.p.-c.) werd de voL I ingevald. Daardoor is het mogelijk om na te gaan of de aselecte steekproeftrekking geleld heeft tot een representatieve verdeling van enkele kenmerken bij de steekproef (VOL I). In de tweede kolom van de tabellen 10 en 11 wordt per verblijfsduurgroep de verdeling van de steekproefpatiënten over de variabelen weergegeven. Door vergelijking van kolom l (de landelijke populatie) en kolom 2 (de steekproef) wordt duidelijk, in welke subgroepen de steekproefpatienten in belangrijke mate over- respectievelijk ondervertegenwoordigd mijn.

Bij nadere analyse van tabel 10 blijkt dat in de steekproef van lang en continu opgenomen patiënten (2-5 jaar) aanzienlijk meer patiënten voorkwamen met een leeftijd van 35-44 jaar en de diagnose schizofrenie, dan men op basis van de landelijke populatie zou mogen verwachter. Het aantal patienten met en niet organische psychose (excl. schizofrenie en affectieve puychose), was darantegen in de steekproef duidelijk ondervertegenwoordigd. Ten aanzien van de andere subgroepen van de steekproef waren de verschilien marginaal.

De steekproef van zeer lang opgenomen patiënten $(z .1 .0 . p$.$) liet$ een oververtegenwoordiging van mannen zien (tabel 11), en mindex patienten met de diagnose "persoonlijkheidsstoornis". Voor de overige kenmerken bleken de verdelingen in de steekproef en 
populatie goed overeen te stemmen. Het feit dat licht geestelijk gehandicapten (debilitas) wel voorwamen in de steekproef, madr niet in de landelijke cijfers, kan uit een verschil met het selectiecritexium van de landelijke gegevens worden verklaard. Zo werden in het onderzoek, in tegenstelling tot de landelijke cijfers, alie patienten met een primaire diagnose "debilitas" tot de doelgroep gerekend.

Alhoewel er aus enkele ultzonderingen zijn, lijkt de conclusie gerechtvaardigd dat de steekproeftrekking geresulteerd heeft in een representatieve verdeling van genoemde kenmerken over de patienten.

ad c: in hoeverre heeft selectieve non-respons gelleid tot een niet-representatieve verdeling van de respons-groep, dit zowel ten opzichte van de steekproef als de landelijke populatie?

De steekproeftrekking is dus in har opzet geslaagd. Belangrijker dan de vraag naar de representativiteit van de steekproef is echter de representativiteit van de responsgroep, de groep van patiënten waarvoor de VOL I \& II werd Ingevuld. Op gegevens verzameld bij deze groep zullen immers de conclusies en aanbevelingen van dit onderzoek worden gebaseerd. Daarom werd evemeens de verdeling van kenmerken bij de responsgroep vergeleken met de populatiewaarden en de verdeling van de steekproef. In de derde kolom van de tabellen 10 en 11 zijn de verdelingen van de responsgroep weergegeven.

Bij een vergelijking van de latste twee kolonmen blijkt dat de responsgroep en steekproef nauwelijks in spreiding over kenmerken van elkaar verschillen. Er was dus geen selectieve non-respons. Wel bleven de bij b genoende verschillen tussen steekproef en populatie ook bestaan tussen responsgroep en populatie. 
De gegevens van de derde verblijfsduurgroep, de lang mar aiscontinu opgenomen patiënten (1.0.p.-dc.), zijn onvolledig. Van de 92 patienten van de steekproef zijn voor 50 patiënten (non-responsgroep) gegevens beschikbaar over geslacht, leeftijd, burgerlijke staat, juridische situatie en diagnose. Bij een onderlinge vergelijking bleken de patiëmten van de respons- en non-responsgroep bij toepassing van de $x^{2}$-toets niet significant ( $P>.05$ ) op dere kemmerken van elkaar te verschilien. Het enige opvallende in de desbetreffende kruistabellen is de jongere leeftijd van de nonresponsgroep. Van deze groep is 798 jonger dan 45 jaar, 62 zelfs jonger dan 35 jaar. De respectlevelijke ciffers voor de responsgroep zijn $69 \%$ en $41 \%$.

In verband met het kleine aantal patiënten en de betrekkelijk hoge non-respons kunnen de resultaten voor de groep van discontinu opgenomen patiënten een vertekend beeld te zien geven. De bevindingen voor deze groep van patiënten zijn dus slechts in zeer beperkte mate generaliseerbaar.

\section{2. Steekproeftrekking bij de psychiatrische dagziekenhuizen}

In Nederland waren eind 198362 instellingen voor psychiatrische dagbehandeling door het ziekenfonds erkend, met in totaal 1665 plaatsen en 2044 ingeschreven patiënten (GHIGV, 1984). Uit het inventariserende onderzoek van scheffer \& Van den Hout (1981) bleek dat deze instellingen onderling aanzienlijk verschilden, wat betreft het type voorziening, huisvesting, autonomie van staf en behandeling en tevens wat betreft doelstelling (primaire/secundaire dagbehandeling), soort programma's en doelgroep. Helaas was van deze 62 instellingen niet bekend, in welke dagbehandelingscentra wel en in welke nuet patienten werden begelaid die daarvoor langdurig opgenomen waren geweest in een a.p.z. "Wel kon van een aantal instelingen op goede gronden worden aangenomen dat zij nawwelijks de door ons bedoelde patiénten zullen begeleiden. Het ging daarbij om dagcentra verbonden aan kinderen jeugdpsychiatrische instelingen (6), universiteitskinieken (2) en andere categoriale ziekenhuizen (2). Ook werden de dag- 
centra, warvan scheffer van den Hout (1981) aangaven dat zij voornamelijk of uitsluitend een primaire dagbehandelingsfunctie verwulden (ter voorkoming van kIinische 24-uurs opmame), buiten net steekproefkader gelaten $(N=15)$.

Bif de resterende 37 psychiatrische dagziekenhuizen werd er nar gestreefd on 150 patiënten voor dit onderzoek te benaderen. Ondat bij een steekproeftrekking bij 20 instellingen al spoedig bleek dat het streefgetal van 150 patiênten zeker niet gehaald zou worden, werd de steekproeftrekking uitgebreid tot alle 37 instellingen. Bif 15 instellingen (41\%) stonden geen voor dit onderzaek relevante doelgroeppatiënten ingeschreven. Het ging daarbij om 11 dagzilekenhuizen, die onderdeel waren van een algemeen psychiatrisch ziekenhuls, 3 van een psychiatrische afdeling van een algemeen ziekenhuls, en 1 van een categorial psychiatrisch ziekenhuis. Zes instellingen (168) hebben om uiteenlopende redenen (personeelsgebrek, 4x; arbeidsbelasting door ander onderzoek, $2 x$ ) geen medewerking aan dit onderzoek verlenend (bijlage 5). In de resterende 16 instelingen met doelgroeppatienten (43\%) was bij 125 patiënten aangegeven dat zij aan onze doelgroepdefinitie voldeden.

De bepaling van de doelgroeppatiënten binnen de dagziekenhuizen werd niet door de onderzoekers uitgevoerd, mar werd verricht door een contactpersoon binnen de instelling op basis van een schriftelijke handleiding. Wel werd zo nodig nadere toelichting gegeven. De uitwoeringsprocedure was verdex identiek aan die in de psychiatrische ziekenhuizen.

10.2.1. Respons

Gedurende het verdere onderzoek bleek op basis van gegevens van de VOL $I$, dat 19 van de 125 patiênten alsmog niet aan de doelgroepomschrifving voldeden, namelijk 18 patiënten door een kortere a.p.z.-verblijfsdur en 1 patient door de diagnose "dementie". De 1.0.p.-populatie (tevens steekproef) van de 16 instelingen bestond dus uit 106 patiënten. Voor 86 (8I\%) van deze patienten werd zowel de VOL I als de VOL II ingevuld en geretourneerd, terwijl voor 78 ( 748 ) alle drie de vragenlijsten beschikbaar waren. 
Concluderend: er is sprake van een hoge respons op de vol I \& VOL II. Ook met de respons op alle drie de vragenijjsten, met bijna driekwart van de patienten, waren wij zeer tevreden.

\subsubsection{Representativiteit}

Ult het voorgaande kan worden afgeleid dat het veel moeite heeft gekost om in de psychiatrische dagziekenhuizen voldoende patiênten met een lang a.p.z.-verleden te traceren. Het aantal doelgroeppatienten in psychiatrische dagbehandeling werd bij het begin van het onderzoek duidelijk te hoog getaxeerd. De intentie was steekproefonderzoek, terwijl achteraf gezien - met enige beperkingen - eerdex sprake was van een populatieonderzoek. Zowel het aantal deelnemende instellingen als de volledigheid van de respons geven voldoende warborgen dat de responsgroep een natuurgetrouwe afspiegeling is wan de populatie.

\subsection{Steekproeftrekking bij de beschermende woonvormen}

op 31 december 1983 vielen 120 beschermende woonvormen onder de Tijdelljke Subsidiematregel Matschappelijke Dienstverlening (T.S.M.D.). Van deze instellingen, waarin op dat moment 2700 bewoners verbleven (N.C.G.V., 1985), werd bij de steekproeftrekking uitgegaan.

ook was bekend dat ongeveer tweederde (66\%) van de bewoners $\operatorname{van}$ deze instellingen ooit eens opgenomen waren geweest in een psychilatrisch ziekenhuis (Haveman, Brook \& Burger, 1983; Haveman, $1982 \mathrm{a})$. Veel moellijker was het om het a andeel bewoners te bepalen dat voorafgaand, volgens de in alt onderzoek gehanteerde definitie, langaurig in een psychiatrisch zlekenhui opgenomen is geweest. Volgens een schatting van de Nederlandse Vereniging voor Beschermende Woonvormen was dit ongeveer 80 van de patienten met een psychiatrische opname. Bovengenoemde informatie leidae tot een schatting van het steekproefkader op \pm 1450 bewoners van beschermende woonvormen. Bij de steekproeftrekking werd gestreefd naar een deelname van \pm 150 bewoners aan dit onderzoek, ongeveer $10 \%$ van de populatie. 
Om dit aantal te bereiken werden in eerste instantie 25 aselect binnen de T.S.M.D.-lijst gekozen instellingen aangeschreven. Enkele instelingen bileken echter om uiteenlopende redenen (bijlage 5) voor deelname aan het onderzoek af te vallen, zodat de steekproef van instellingen is uitgebreid tot 36 . Uiteindelijk hebben 21 beschermende woonvormen met doelgroepbewoners deelgenomen aan het onderzoek.

Evenals bij de psychiatrische dagziekenhuizen werden alle bewomers die aan de doelgroepdefinitie voldeden ( $N=191$ ) voor ait onderzoek benaderd. De verdere stappen in het onderzoek bij de beschermende woonvormen waren gelijk aan die in psychiatrische dagziekenhuizen.

\subsubsection{Respons}

Gedurende het onderzoek bleek êén bewoner door de diagnose "dementie" alsnog niet aan de doelgroepdefinitie te voldoen. De populatie en tevens steekproef van 21 beschermende woonvormen bestond dus uit 190 bewoners, die vroeger langdurig waren opgenomen in psychiatrische ziekenhuizen.

Na het afsluiten van de dataverzameling was van 179 bewoners (94\%) zowel de voL I als de vol I I ingevuld. Omdat de meeste variabelen van het onderzoek gescoord werden met behulp van deze twee vragenlijsten, ziljn de gegevens over deze sector, dank zij de medewerking van bewoners en persomeel, dus vrij volledig. voor 145 bewoners (76\%) waren alle drie vragenlijsten ingevuld en beschikbaar. Ook de derelname aan de interviews (VOL III) was dus, in wergel.⿲丿丨king met de andere sectoren, hoog.

\subsubsection{Representativiteit}

De respons op de vol I en II was zo volledig, dat de responsgroep en steekproefgroep nauwelijks van elkaar verschilden. Tevens is de vraag naar de representativiteit van de steekproef c.q. responsgroep ten opzichte van de respectievelijke populatie van bewoners wan de 21 beschermende woonvormen weinig relevant, ondat 


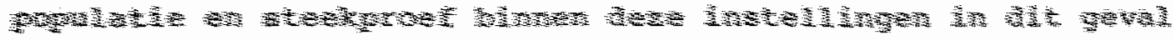

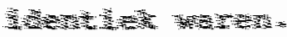

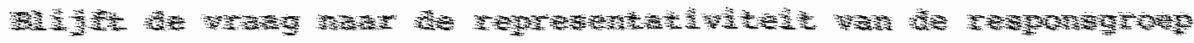

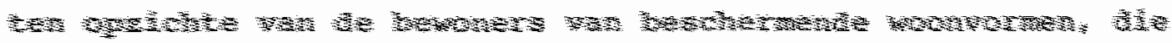

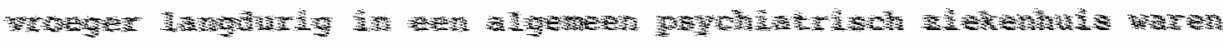

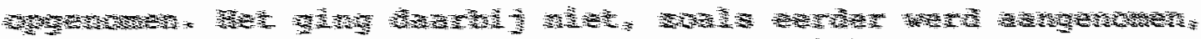

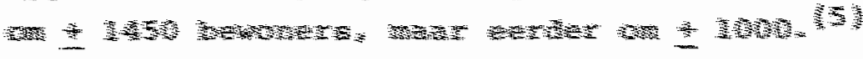

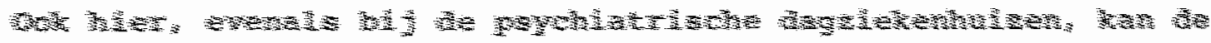

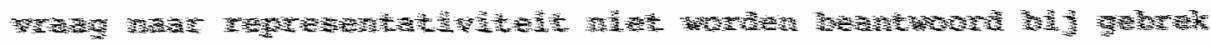

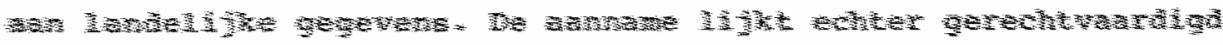

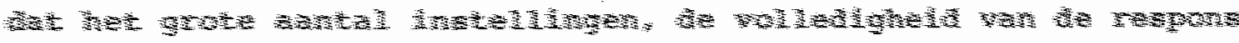

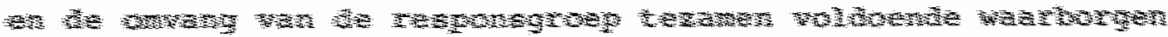

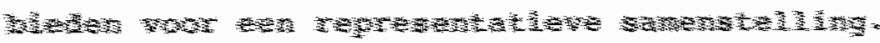


DEEL IV - RESULTATEN

11. Oordeel van hulpverleners over mogelijkheden van vervangende zorg (resultaten voor de criteriumvariabele)

Als criterium voor de beantwoording van de vraag, of een patient a] dan niet voor vervangende zorg in aanmerking kwam, werd het oordeel van de hoofdbehandelaar (psychiater of psycholoog) en een verpleegkundige genomen. Daartoe was an deze hulpverleners verzocht om, onafhankelijk van elkaar, voor een a antal alternatieve voorzieningen (zie tabel 12 ) aan te geven, of de patient voor overplaatsing in aanmerking kwam. Als positieve verwangende zorg-indicaties werden al die gevalien beschouwd, waarin de hoofabehandelaar en de verpleegkundige in oordeel overeenstemden. Een "ja" van de ene beoordelaar moest tenminste met een "misschien"t van de andere beoordelaar overeenstemen.

Voor een aantal patiënten bleek dat, ondanks een langdurig verblijf in het ziekenhuis, het perspectief op een alternatief niet verloren was gegaan. De hoofdbehandelaars en verpleegkundigen vonden dat voor ongeveer $30 \%$ van de lang opgemomen patienten mogelijkheden bestonden voor andere vormen van huisvesting en zorg dan het huidige verblijf op de afdeling of in het paviljoen van een psychiatrisch ziekenhuis.

De behoefte aan huisvesting en $g g z$-begeleiding was voor deze groep patiënten zeer verschillend (tabel 12), en varieerde van zelfstandige kamerbewoning zonder begeleiding door Riagg of psychiatrische polikiinjek tot bescherma kleinschalig wonen op het terrein van een psychiatrisch ziekenhuls. 
Tabel 12: Lang opgenomen patienten van 5 psychiatrische ziekenhulizen naar mogelijkheden van vervangende zorg: absoluut en percentages.

$a b s$

g

door beide beoordelars ingedeela voor:

- zelfstandige kamerbewoning zonder agg $z$-begeleiding

41,0

- flat-/huisbewonting met ex-patienten zonder aggz-begeleiding

- zelfstandige kamerbewoning met agg $z$-begele laing $8 \quad 2,1$

- flat-/huisbewoning met ex-patienten met aggz-begeleiding

- psychiatrische dagbehandeling/dagzorg 16 4,2

- psychiatrisch hostel/sluisinternat

- beschermende woonvorm buiten het ziekenhuisterrein

- beschermd kleinschalig wonen op net zilekenhuisterrein 37 9,7 subtotaal 116 30,4

- tenminste één alternatieve voorziening genoemd door één beoordelaar 180 47,3

- geen alternatieve voorziening genoemd door beide beoordelaars 85 22,3 totaal 381 100,0

Voor 7 van de patiènten behoorde huisvesting buiten de ggz-sector tot de mogelijkheden, namelijk in de vorm van zelfstandige kamerbewoning of samenwonen met andere ex-patiënten. Voor het merendeel van deze patiênten werd daarbij wel als voorwarde gesteld dat begeleiding platsvindt door Riagg of psychiatrische polikliniek. Van de lang opgenomen patiënten kwam 13 o voor semimurale voorzleningen van de ggz in aanmerking. Met 128 werd datarbj een belangrijke plats ingeruimd voor de beschermende woonvormen met een pensiontehuis-functie. Slechts weinig patiën- 
ten (18) kwamen daarentegen in arnmerking voor de hostelfunctie bimnen het beschermd wonen.

Dok werden betrekkelijk weinig patienten genoend voor psychiatrische dagbehandeling. Het is ammemelijk dat dit oordeel mede bepaald werd door de omstandigheid dat op het tijdstip van onderzoek in bijna tweederde van de psychiatrische ziekenhuizen geen lang opgenomen patiênten voor dagbehandeling stonden ingeschreven. Uit inventariserend onderzoek van scheffer en Var den Hout (1981) em Geerlings e.a. (1983a) en een literatuuronderzoek van Schene en Gersons (1985) blijkt dat de doelgroep voor dagbehandeling vooral bestaat uit personen, waarbij opnamepreventie of verkorting van een opname na een kortdurend verblijf in het psychiatrisch ziekenhuis als doelstelling voorop stad. Modelprogramma's voor lang opgenomen patiënten - gericht op xesocialisatie en ontslag - zoals door Wing, Bennett, Shepherd, Watts e.a. in Engeland zijn uitgewerkt, zijn in Nederland echter nog schaars. Anderzijds is het mogelijk dat door de financieringswoorwarden bij dagbehandeling te hoge eisen worden gesteld aan zowel de lang opgenomen patienten als hun hulpverleners. Door de in de voorwarden genoemde eis dat geselecteerd dient te worden op patiënten die op betrekkelijk korte termijn geen dagbehandeling meer hoeven te ontvangen, maar zelfstandig kunnen functioneren, blijft voor dit type van zorg alleen een beperkt aantal lang opgenomen patienten over. Het gaat dan om patiënten, warvoor het incidentele karakter van de ambulante nazorg onvoldoende is en die overdag behoefte hebben aan regelmat en gestructureerde activiteiten, mar wel over een eigen onderkomen beschikken en goed sociaal redzam zijn, zodat 24 -uurs klinische zorg niet nodig $\mathrm{ls}$ Tenslotte bleek voor ongeveer 10 : van de steekproefpatientan een indicatie te bestaan voor beschernd samenwonen in kleinschalige voorzieningen op het instelingsterrein.

zoals in een eerder rapport meer in detail werd angegeven (Haveman, Poelljoe \& Tan; 1986), vraagt de verschiliende begeleidingsbehoefte van de patienten om een gedifferentiecrde capaciteitsplanning van ggz-voorzieningen door de overheid. Daarbij zal. vooral het aantal beschikbare plaatsen in beschermende woonvormen 
en zgn. sociowoningen aanzienlijk moeter worden uitgebreid om daadwerkelijk een nieuw perspectief te scheppen voor lang opgenomen patienten van psychiatrische ziekemhuizen. Het principe van "aambod schept vraag" geldt ook hier.

Maar ook bij aanwezigheid van voldoende geschikte plaatsen in dergelijke voorzieningen zal het vooral van de actieve steun van extra- en intramurale hulpverleners afhangen, hoeveel van de patielnten de moeilijke stap naar buiten kunnen ondernemen. In Nederland heeft vooral Delimon (1986) gewezen op het voortdurende proces van motiveren van en onderhandelen met de patient bij platsing in andere woonvormen. Naast immateriele aspecten, zoals het motiveren van patienten en training in sociale vaardigheden, zal tevens hulp nodig zijn bij meer materiezle aspecten, zoals hulsvesting en uitkeringen. Intensieve samenwerking tussen Riagg, RIBW en psychiatrisch ziekenhuis is daarvoor onmisbaar, zowel op het niveau van medewerkers als directie en bestuur.

Omdat de lang opgenomen patienten in het psychiatrisch ziekenhuis gebruik konden maken, indien dit noodzakelijk was, van medische hulp, fysiotherapie en matschappelijk werk, zullen dergelijke voorzieningen ook buiten de geestelijke gezondheidszorg, zoals huisarts, fysiotherapeut en algemeen maatschappelijk werk, bij het overleg betrokken dienen te worden. Tevens zal zowel programmatisch als personeelsmatig voldoende aandacht moetien worden gegeven aan de dagopvang van patiënten en hun vrijetijds-besteding 's avonds en in het weekeinde.

Het in dit onderzoek gevonden percentage van $30 \%$ eventueel te hexplatasen lang opgenomen patiënten 1 ijkt op het eerste gezicht indrukwekkend, mar is het minder, als men beseft dat het bij bijna los vervangende zorg betreft in de vorm van kleinschalig beschermd wonen op het terrein van het psychiatrisch ziekenhuis. Bij een vergelijking met soortgelijk onderioek in de angel-saksische landen zijn de gevanden percentages geenszins dysproportioneel te noemen. In een reeds eerder genoema onderzoek bij een 15-tal psychiatrische ziekenhuizen in Engeland en Wales vonden Mann en Cree (1976) dat éénderde van hun steekproefpatiënten met 
een verblijfsduur van 1 tot 3 jaar ontslagen zou kumen worden, indien geschikte voorzieningen (huisvesting, nazorg e.d.) in de maatschappij aanwezig zouden zijn. Wel tekenden zij daarbijaan dat deze groep patienten in het algemeen meer beperkingen kende, dan de toenmalige bewoners van hostels. Faden en Goldman (1979) merken in een rapport van het National Institute for Mental Health in de V.S. op, dat uit de verschillende substitutie-onderzoeken in hun land regelmatig geconcludeerd wordt dat tenminste 30 van de lang opgenomen psychiatrische patienten niet in de juiste voorzieningen verblijft. Wel hadden de in dit rapport genoemde onderzoeken veelal ook betrekking op instellingen, warvoor de substitutiemogelijkheden in ons onderzoek niet werden bestudeerd (bv. nursing homes ${ }^{(6)}$ ).

Indien door het bovenstaande de indruk wordt gewekt dat de 30 s een stabiele substitutiemarge is, zowel in de tijd gezien als in international perspectief, dan willen wij deze indruk direct corrigeren. De onderzoeksdesigns, de bestudeerde voorzleningen en de steekproefpatiënten in de desbetreffende studies verschilden zoveel van elkaar dat het eerder aan toevallige omstandigheden is te wijten dat de onderzoekers bij de magische grens van éénderde van de lang opgenomen patiënten van psychiatrische ziekenhuizen uit tkomen.

\section{Toetsing van hypothesen}

In de voorgaarde hoofdstukken is aangegeven voor welke onafhankelijke variabelen in dit onderzoek is gekozen; welke samenhang verondersteld wordt tussen deze variabelen en de mogelijkheid van vervangende zorg (hypothesen): hoe de afhankelijke en onafhankelijke variabelen zijn geoperationaliseerd; op welke manier de gegevens werden verzameld; en hoe groot de groep van patiẻnten was die voor vervangende zorg in aanmerking kwam. Vervolgens zal in ait hoofastuk worden geschetst hoe de toetsing van de hypothesen heeft plaatsgevonden, en zullen de resultaten worden toege1 icht. 
De $u n$ hoofdstuk 6 geformuleerde hypothesen zijn op drie manieren getoetst, namelijk:

(a) door de patienten van psychiatrische ziekenhuizen die volgens de hulpverleners voor vervangende zorg in aanmerking komen te vergelijken met de groep opgenomen patienten die niet voor vervangende zorg in aanmerking komt;

(b) door de patienten van psychiatrische ziekenhulizen te vergelijken met de bewoners van beschermende woonvormen;

(c) door de patienten van psychiatrische ziekenhuizen te vergelijken met de patienten in psychiatrische dagbehandeling.

Toetsing (a): als de bestudeerde variabelen werkelijk een factor van betekenis waren voor het oordeel ten aanzien van vervangende zorg, dan zal dit ook tot uitdrukking moeten komen - zo is de redenering - in de scoreverdeling op de variabelen binnen de twee eerder genoemae groepen. Een statistisch significant verschil in de voorspelde richting bij éénzijdige toetsing - een verschil tussen beide groepen dat nauwelijks verklaard kan worden door toevalsverdelingen bij steekproeftrekking - geeft een indicatie dat de betrokken variabele een rol speelt in het oordeel van hulpverleners over mogelijkheden van vervangende zorg. Aan de hand van Kendall"s tau en de getabelleerde data kan verder worden beoordeeld of het ook om een relevant verschil gaat. Het eerste soort toetsing, toetsing a, heeft betrekking op mogelijkheden voor vervangende zorg. Het gat om beoordelingen en taxaties, niet om daadwerkelijke plaatsingen. Ook dient men steeds te beseffen at het begrip "vervangende zorg" in dit onderzoek breed is gedefinieerd, namelijk van zelfstandige huisvesting zonder professionelle begeleiding tot en met kleinschalig beschermd wonen op het terrein van een psychiatrisch ziekenhuis.

Toetsing ( $b$ en $c$ ): het tweede en derde soort toetsing was concreter. Als referentiegroep diende de groep personen die daadwerke1ijk na een langdurige opname de stap naar een beschermende woonvorm (toetsing b) en psychiatrische dagbehandeling (toetsing c) makte. 
Zoals in de hypothesen is verwoora" mag verwacht worden dat in geval van restricties in het ontslagbeleid van psychiatrische ziekenhuizen en van selectief intakebeleid van deze vervangende zorgvormen daar bijvoorbeeld minder personen (1.0.p.) met slechte zelfredzamheid, suicidal gedrag e.d. zullen voorkomen aan in psychilatrische ziekenhuizen. Of dit ook werkelijk zo is, zal moeten bilijken bij de toetsing. Een statistisch significant verschil op de desbetreffende variabele zal ook hier weer worden geinterpreteerd als een indicatie voor het bestaan van een ontslagbelemmerende factor, mar dan toegespitst op een bepaalde voorzieningensector.

Als in de volgende hoofdstukken over "verschillen" wordt gesproken, dan wordt bedoeld "statistisch significante verschillen". De drie toetsingen tezamen geven een beeld van de consistentie van de resultaten voor een bepalde hypothese.

\subsection{Vaardigheden (bivariate toetsing)}

In hoeverre onderscheiden zich nu lang opgenomen personen in algemene psychiatrische ziekenhuizen, wat betreft vaardigheden en gedragsbeperkingen, van de personen die na een dergelijke langdurige klinische opname in psychiatrische dagbehandeling zijn of in een beschermende woonvorm verblijven?

In dit hoofdstuk zal een indruk worden gegeven van de vaardigheden van de bewoners van bovengenoemde voorzlieningensoorten. Een hoog puntenaantal op en index betekent dat veel van de bedoelde vaardigheden ontbreken, een lage score dat betrokkene het, wat. dit aspect betreft, goed doet.

Bij de onderverdeling van de indices naar scoringscategorieein ia gebruik gemakt van informatie uit het vooronderzoek. Als referentiegroep voor de normering van de scores dienden een 24-tal demente bejaarden. Deze patiènten van een psychogeriatriache afdeling hadden op alle indices aanzienlijk meer beperkingen dan de patiênten van de overige afdelingen en van de pensiontehulizen. De beste score van $75 \%$ van deze 24 patiënten, de kwartielscore, 
1s vervolgens gekozen voor de markering van de overgang tot een "slechte" of "zeer slechte" score. Voor basale zelfredzaamheid was alt een puntenaantal van 6, voor potentiěel sociale vaardigheden 4, woor interne sociale integratie 6, en voor externe sociale integratie en puntenaantal van 25. Aan de numerieke onderverdeling van de overige categorieën ligt geen extern criterium ten grondsIag.

\subsubsection{Bagale zelfredzaamheid (BZR)}

Schudel (1976) kwam in zijn onderzoek bij chronische patiënten van een 4-tal psychiatrische ziekenhuizen tot de conclusie dat vrijwel alle patienten over een grote mate van zelfredzaamheid en zelfstandigheld beschikten. Mu, ongeveer 10 jaar later, moet daarbij een uitzondering worden gemaakt voor 15 van de patiënten. Deze patiënten bleken slecht tot zeer slecht te functioneren op essentiële zelfredzamheidsaspecten (tabel 14 ).

Het merendeel $( \pm 75 \%)$ van de lang opgenomen patiënten in de psychiatrische ziekenhuizen is echter nog steeds goed zelfredzaam in de basale, lichamelijke functies. Indien er wel problemen op dit gebied zijn, dan komt dit vooral tot uiting in hulpbehoefte bij aankleden en matregelen bij incontinentie (tabel 13). 
Tabel 13: Aspecten van basale zelfredzaamheid blj lang opgenomen patienten in psychiatrische ziekenhuizen $(N=381)$ : percentuele verdeling van antwoorden.

\begin{tabular}{|c|c|c|c|}
\hline $11 e 2 e$ & + & $+1-$ & $=$ \\
\hline - hulp bij ankleden & 778 & 178 & 68 \\
\hline - "s nachts incontinent & 83 & 7 然 & 108 \\
\hline - urine/faeces op ongewenste plaatsen & 848 & 98 & 78 \\
\hline - overdag incontinent & 868 & 7 客 & 7 \\
\hline - besef over aard instelling & 84 & 9 욤 & 78 \\
\hline - kent personeel bij naam & 88 웋 & $5 \%$ & $7 \%$ \\
\hline - hulp bij eten nodig & $83 \%$ & 158 & 28 \\
\hline - Kan lopen & 84. & 138 & 38 \\
\hline - kan bedoeling duidelijk maken & 878 & 11.8 & 28 \\
\hline - begripsvermogen & $89 \%$ & $11 \%$ & -- \\
\hline - oriëntatie binnen instelling & 938 & 48 & 38 \\
\hline - reageert op naam & 95 & 58 & -- \\
\hline - speciale voorzieningen voor uit bed vallen & 978 & 18 & 28 \\
\hline - speciale voorzieningen voor ult stoel vallen & 97 웅 & 28 & 18 \\
\hline
\end{tabular}

$+\quad=$ zelfredzaam

$+/-=$ gedeeltelijk zelfredzam

- $\quad$ niet zelfredzaam

Bij het eerste soort toetsing (a) bleek dat op alle BzR-items statistisch significante verschillen bestonden $(p<.0005)$ tussen de groep patienten aie wel en patiënten die njet voor vervangende zorg in a anmerking kwam. Ook bij de vergelijking van de steekproefpatiënten van psychiatrische ziekenhuizen met de steekproef van bewoners van beschermende woonvormen (toetsing b) konden voor 10 aspecten verschilien ( $p<.05$ ) worden geconstateerd. Als groep gezien waren de personen in beschermende woonvormen meer zelfredzaam .

Geen verschillen werden gevonden, wat betreft het besef over de aard van de instelling war betrokkene verblijft, het begripsvermogen van de patient, het reageren op het noemen van de naam en 
het trefen van voorzieningen om wit bed vallen te voorkomen. Op de drile laatstgeroende 2 tems verschilden ook niet de patienten in psychiatrische dagbehandeling (toetsing c).

De resultaten op itemiveau laten reeds vermoeden dat de zelfredzamheid var patienten een belangrijk aspect is bij de besluitvorming over vervangende zorg. De resultaten op index-niveau bevestigen ait beeld ( $t a b e 1$ 14).

HI: Naarmate de basale zelfredzaamheid van lang opgenomen patiënten geringex is, komen zij minder in aanmerking voor vervangende zorg.

Tabel 14: Lang opgenomen patienten in psychiatrische ziekenhuizen naar mate van basale zelfredzaameid (BZR) en mogelijkheden van vervangende zorg; absoluut en percentages.

\begin{tabular}{|c|c|c|c|c|c|c|c|}
\hline $\mathrm{BZR}$ & $\begin{array}{l}\text { goed } \\
0-2\end{array}$ & & $\begin{array}{l}\text { red } \\
3-5\end{array}$ & lelijk & $\begin{array}{l}\text { slecht } \\
6-11\end{array}$ & $\begin{array}{l}\text { zeer slecht } \\
12-28\end{array}$ & totaal \\
\hline \multicolumn{8}{|l|}{ vervangende } \\
\hline zorg-groep & 103 & $(368)$ & 9 & $(238)$ & $(118)$ & $-\quad(08)$ & $(308)$ \\
\hline overigen & 184 & & 30 & & 32 & 20 & 265 \\
\hline totaal & 287 & $(100 \%)$ & 39 & $(100 \%)$ & $36(1008)$ & $20(100 \%)$ & $381(1008)$ \\
\hline
\end{tabular}

Een goede zelfredzaamheld, wat betreft een aantal belangrijke lichamelijke en psychologische functies, lijkt een essentieel criterlum te zijn bij de beoordeling, of een patient wel of niet voor vervangende zorg in aanmerking komt. Van de 116 patiënten die door belde hulpverleners voor vervangende zorg waren ingedeeld" hadden 103, ofwel 89\%, een goede BzR-score.

Naar aanleiding van tabel 14 kan worden geconstateerd dat met de a Ename van de zelfredzamheid minder patiënten voor vervangende zorg in aanmerking komen. Bij de 4 patiënten die slecht zelfredzaam waren en toch voor vervangende zorg werden ingedeeld, werd kleinschalig beschermd wonen op het terrein $(N=2)$ en buiten het 
terrein van het psychiatrisch ziekenhuis ( $N=2)$ aanbevolen. Een goede basale zelfredzaamheld was echter geen volaoende voorwararde voor ontslag. Zo werd 648 van de patienten met een goede BZR toch niet geschikt geacht woor vervangende zorg.

Tabel 15: Personen $(1.0 . \mathrm{p}$.$) in algemene psychiatrische ziekenhui-$ zen (APZ), beschermende woonvormen (BWV) en psychiatrische dagbehandeling ( $P D B$ ) naar mate van basalle zelfredzaamheid; percentages.

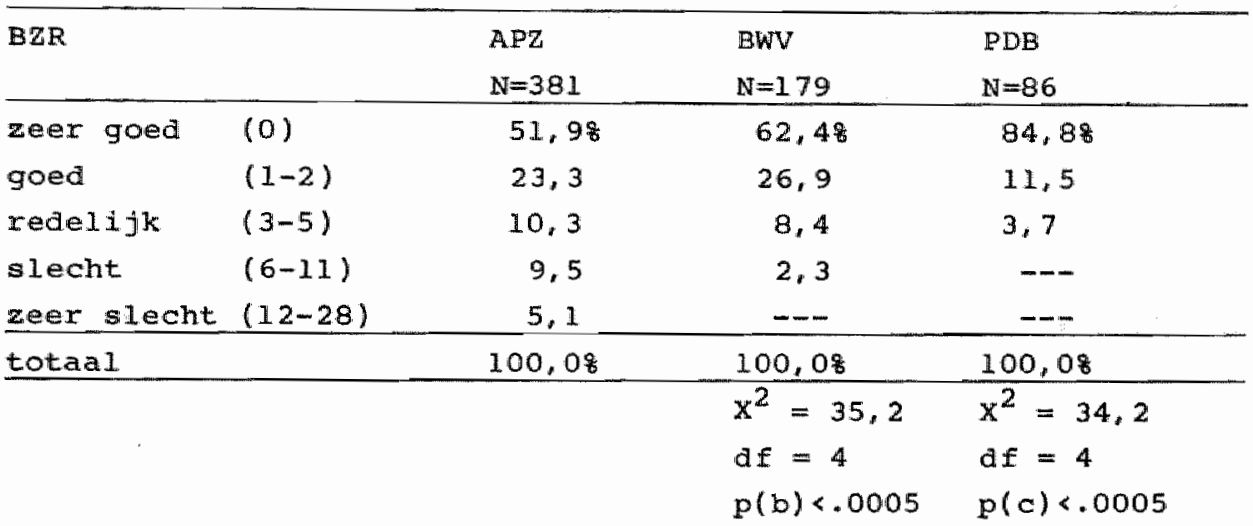

De personen die na een langdurige klinische opname op het tijdstip van onderzoek in beschermende woonvormen of psychiatrische dagbehandeling verbleven, waren in het algemeen beter zelfredzaam dan de personen (1.0.p.) die in psychiatrische ziekenhuizen verbleven.

Concluderend, kan worden vastgesteld dat hypothese 1 door de drie toetsingen wordt ondersteund. Hoe geringer de basale zelfredzamheld van lang opgenomen patienten in psychiatrische ziekenhuizen is; des te minder komen zij volgens hun hulpverleners in aanmerking voor vervangende zorg en des te minder worden $z i j$ ook daadwerkelijk geplaatst in beschermende woonvormen en psychiatrische dagbehandeling. 


\subsubsection{Potentiel sociale vaardigheden (PSW)}

Voor een meer zelfstandig leven butten de instelling zijn meer vardigheden nodig dan het kunnen wassen, kleden, eten e.d. Voor een grotere onathankelijkheid is het tevens noodzakelijk dat betrokkene over valrdigheden beschikt zoals boodschappen doen, gebruik maken van openbaar vervoer, bereiden var maaltijden en telefoneren.

Uit tabel 16 valt af te lezen dat een aantal patienten in psychiatrische ziekenhuizen deze vaardigheden niet had.

Tabel 16: Aspecten van potentieel sociale vaardigheden bij lang opgenomen patiënten in psychiatrische zilekenhuizen $(\mathbb{N}=381)$; percentuele verdeling van antwoorden.

\begin{tabular}{lllll}
\hline Potentieel Sociale vaardigheden (PSV) & + & $+/-$ & - \\
\hline - In stat eenvoudige warme maltijd te bereiden & 188 & 368 & $46 \%$ \\
- In staat boodschappen te doen & 358 & 378 & $28 \%$ \\
- in staat openbaar vervoer te gebrulken & 458 & 238 & 328 \\
- in staat op te bellen & $58 \%$ & $18 \%$ & 248 \\
\hline
\end{tabular}

$+\quad=$ sociaal vaardig

$+/-=$ gedeeltelijk sociaal vaardig

- = niet sociaal vaardig

Betrekkelijk weinig patlënten (18\%) waren in staat om volledig zelfstandig een eenvoudige warme maltijd te bereiden. Alhoewel. er in dit opzicht wel enig verschil was tussen mannen en vrouwen (11. versus 268), gold ook voor de vrouwen dat 398 niet tot koken in staat was en 35 daarbij gedeeltelijk hulp nodig had. Problemen waren er ook, wat betreft het boodschappen doen. Eénderde van de patienten was daartoe zelfstandig in staat, terwijl de overige patienten slechts boodschappen konden doen met gedeeltelijke of volleaige personele begeleiding. 
Bijna de helft (45\%) van de patiënten kon zonder hulp gebruik maken van het openbaar vervoer. In dit opzicht deden de mannen. het beter ( $55 \%$ versus 34\%). De meeste patienten konden zelfstandig en doeltreffend een telefoongesprek woeren vanuit een telefooncel. Van de lang opgenomen patienten was 58 s daartoe volledig in stat, $18 \%$ gedeeltelijk en 248 geheel niet.

De groep patiënten van psychiatrische ziekenhuizen die voor vervangende zorg in aanmerking kwam, onderscheidde zich ( $p * .0005$ ) op alle psv-aspecten van de groep paticnten die volgens het hulpverlenersoordeel in de instelling zou moeten blijven (toetsing a). Tevens waren de steekproefpersonen van beschermende woonvormen en centra voor psychiatrische dagbehandeling in het algemeen vardiger $(\mathrm{p}<.0005)$ op de genoemde aspecten dan de patiënten in psychiatrische ziekenhuizen (toetsing b en c). De gevonden verschilien waren ook statistisch significant $(p<.05)$ bij toetsing apart voor mannen en vrouwen.

H2: Naarmate de potentieel sociale vaardigheden van lang opgenomen patiënten geringer zijn, komen zij minder in aanmerking voor vervangende zorg.

Tabel 17: Lang opgenomen patiënten in psychiatrische ziekenhuizen naar mate van potentieel sociale vararigheden (PSV) en mogelijkheden van vervangende zorg; absoluut en percentages.

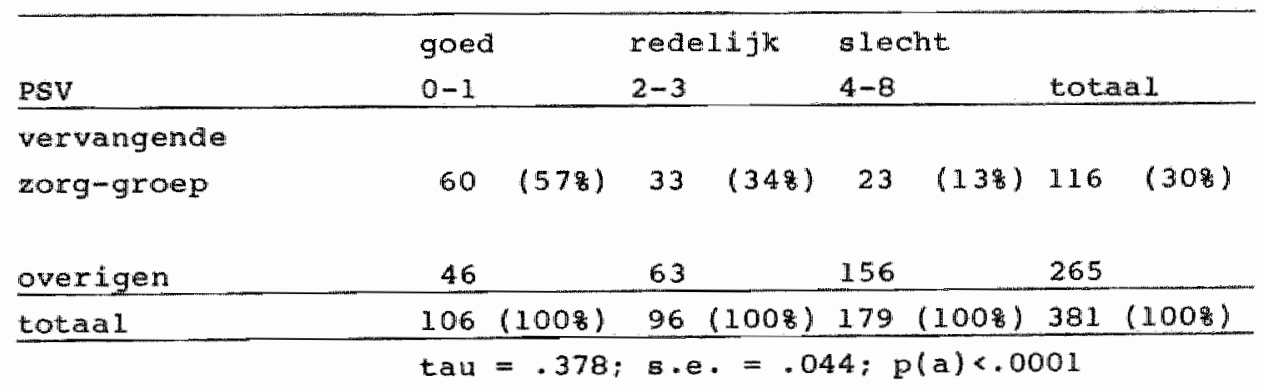


Het is annemelijk dat bij het oordeel van hulpverleners om patienten voor verwangende zorg in te delen, in belangrijke mate rekening wordt gehouden met bovengenoemde socialle vaardigheden. Van de patienten met een goede PSV-score werd $57 \%$ ingedeeld voor vervangende zorg, terwily voor patiênten met een slechte PSVscoxe dit aandeel $13 \%$ was. De relatie tussen potentieel sociale vardigheden en oordeel over vervangende zorg is:

- conseguent dalend: met de afname van de vaardigheden daalt ook het aantal vervangende zorg-patienten,

- relevant: een goede PSV-score is een redelijke voorspeller voor taedeling naar de vervangende zorg-groep $(60 / 116$ x $100=528)$; een slechte PSV-score is een redelijke voorspeller voor het niet in aanmerking komen voor vervangende zorg $(156 / 265 \times 100=$ 59\%); en

- statistisch significant: het is niet aannemelijk dat de gevonden verschillen verklaard kunnen worden door toevalsfluctuaties bij steekproeftrekking alleen.

Tabel 18: Personen (1.0.p.) in algemene psychliatische ziekenhuizen (APZ), beschermende woonvormen (BWV) en psychiatrische dagbiehandeling (PDB) naar de mate van potentieel sociale vaardigheden; percentages.

\begin{tabular}{lcccc}
\hline PSV & & $\begin{array}{l}\text { APZ } \\
\text { N=381 }\end{array}$ & $\begin{array}{l}\text { BWV } \\
\mathrm{N}=179\end{array}$ & $\begin{array}{l}\text { PDB } \\
\mathrm{N}=86\end{array}$ \\
\hline goed & $(0-1)$ & 28,08 & 42,58 & 80,28 \\
redelijk $(2-3)$ & 25,1 & 34,1 & 7,0 \\
slecht & $(4-8)$ & 47,0 & 23,5 & 12,8 \\
\hline totaal & 100,08 & 100,08 & 100,08 \\
\hline & & $\mathrm{x}^{2}=28,2$ & $\mathrm{x}^{2}=81,7$ \\
& & $\mathrm{df}=2$ & $\mathrm{df}=2$ \\
& & $\mathrm{p}(\mathrm{b})<.0001$ & $\mathrm{p}(\mathrm{c}) \times .00001$
\end{tabular}

Het beeld van de meer sociaal vaardige patiënt/bewoner aringt zich ook op, als de gegevens worden bekeken voor personen die na een langdurige opname in vervangende zorg verblijven. De personen 
(1.0.p.) in beschermende woonvormen, mar vooral in psychiatrische dagbehandeling, waren aarzienlijk sociaal vaardiger dan de lang opgenomen patiënten in psychiatrische ziekenhuizen. Viervijfae van de dagbehandelingspatienten kende nauwelijks belemmeringer in de onderscheiden vaardigheden, te weten: telefoneren, bereiden van maaltijden, boodschappen doen en gebruik van openbaar vervoer.

Conclusie: gezien het consistente patroon van de resultaten is voldoende evidentie aanwezig om ook de tweede hypothese als ondersteund te aanvaarden. Hoe geringer de potentieel sociale vaardigheden van lang opgenomen patienten zijn, des te minder komen zij volgens hun hulpverleners in aanmerking voor vervangende zorg. Tevens neemt ook de kans af op een daadwerkelifke plaatsing in een beschermende woonvorm of in psychiatrische dagbehandeling.

\subsubsection{Interne sociale integratie (ISI)}

Bij de vorlige twee variabelen (BZR, PSV) ging het on vaardigheden die nodig zijn voor adequate communicatie en sociale interactie. De sociale vaardigheden van de PSV-index waren zo geformuleerd dat de verpleegkundigen niet het daadwerkelijke gedrag van patienten moesten beoordelen, mar of de patiënten tot bepaalde activiteiten in stat waren.

De volgende twee variabelen - Interne Sociale Integratie (ISI) en Externe Sociale Integratie (ESI) - beogen gedrag op en bulter de afdeling te meten, zoals gezien en beoordeelt door verpleegkundigen. Bij ISI gaat het daarbij om de mate van coosperatief gedrag en sociale aanpassing binnen de instelling. 
Tabel 19: Aapecten van interne sociale integratie bij lang opgenomen patienten in psychiatrische ziekenhuizen ( $N=381)$ : percentuele verdeling van antwoorden*

\begin{tabular}{|c|c|c|c|}
\hline Interne sociale Integratie (ISI) & + & $+1=$ & - \\
\hline - ongevraagd bewoners helpen & 198 & 458 & $36 \%$ \\
\hline - omgaan met 1 of meer bewoners & $38 \%$ & 378 & 258 \\
\hline - zinvol bezig buiten therapie & $37 \%$ & 428 & 211 \\
\hline - praat uit zichzelf met andere bewoners & 458 & 388 & 178 \\
\hline - helpt op de afdeling/in instelling & 618 & $22 \%$ & 170 \\
\hline - gevraagd helpen & 678 & 318 & 28 \\
\hline
\end{tabular}

$+\quad$ sociaal geüntegreerd

$+/-$ = gedeeltelijk sociaal geIntegreera

- = niet sociaal geintegreerd

Het beeld dat Schudel (1976) schetste van het sociale isolement, waarin betrekkelijk veel patiënten ook binnen de instelling verkeren, kwam ook in dit onderzoek naar voren. Een aantal lang opgenomen patiënten vertoonde in het psychiatrisch ziekenhuis een beperkt interactie- en communicatiepatroon. Zo ging één kwart van de patiënten nooit met én of meer bewoners om. Ook hielp $36 \%$ nooit andere patiënten bij bijvoorbeeld eten en spel, 17\% knoopte nooit uit zichzelf een praatje an met andere bewoners, en 21 s was noolt buiten de therapie-uren om actief in de vorm van bijvoorbeeld werken, lezen, spelletjes doen, hobbies en met anderen praten.

Wel hielp meer dan $60 \%$ van de bewoners op de afdeling mee bij bijvoorbeeld afwassen en bloemen verzorgen, of elders in de instelling bijvoorbeeld bij de plantsoenendienst.

De vervangende zorggroep scoorde op alle ISI-items beter $(p<.0001)$ dan de overige steekproefpatiënten van psychiatrische ziekenhuizen (toetsing a), en dat gold ook voor de bewoners van beschermende woonvormen $(\mathrm{p}<.05)$ in vergelijking met de totale steekproef van ziekenhuispatiënten (toetsing b). 
Weinig verschillen werden gevonden tussen kinisch opgenomen patiênten en dagbehandelingspatiënten voor de arie ISI-items, die betrekking hebben op "helpen".

H3: Naarmate de interne sociale integratie van lang opgenomen patienten geringer is, komen zij minder in aanmerking voor vervangende zorg.

Tabel 20: Lang opgenomen patiënten in psychiatrische ziekenhuizen naar mate van interne sociale integratie (ISI) en mogelijkheden van vervangende zorg; absoluut en percentages.

\begin{tabular}{|c|c|c|c|c|}
\hline ISI & $\begin{array}{l}\text { goed } \\
0-2\end{array}$ & $\begin{array}{l}\text { redelijk } \\
3-5\end{array}$ & $\begin{array}{l}\text { slecht } \\
6-12\end{array}$ & totaal \\
\hline \multicolumn{5}{|l|}{ vervangende } \\
\hline zorg-groep & $(488)$ & $43 \quad(338)$ & 14 (118) & (30ㅇ) \\
\hline overigen & 64 & 86 & 115 & 265 \\
\hline totaal & $123(100 \%)$ & $129(1008)$ & $129(1008)$ & $381 \quad(1008)$ \\
\hline
\end{tabular}

Bijna de helft van de patiënten met een goede interne sociale integratie bleek inaerdaad in aanmerking te komen voor vervangende zorg, en verschilde in dit opzicht duidelijk van patiënten met minder sociale contacten op de afdeling. zo werd éénderde van de patienten met een redelijke mate van ISI voor vervangende zorg geindiceerd, en slechts tien procent van de patienten net een geringe mate van ISI. De gevonden relatie was consequent delend en statietisch significant. 
Tabel 21: Personen (1.0.p.) in algemene psychiatrische ziekenhuizen (APZ), beschermende woonvormen (BWV) en psychilatrische dagbehandeling (PDB) nar mate van interme sociale integratie: percentages.

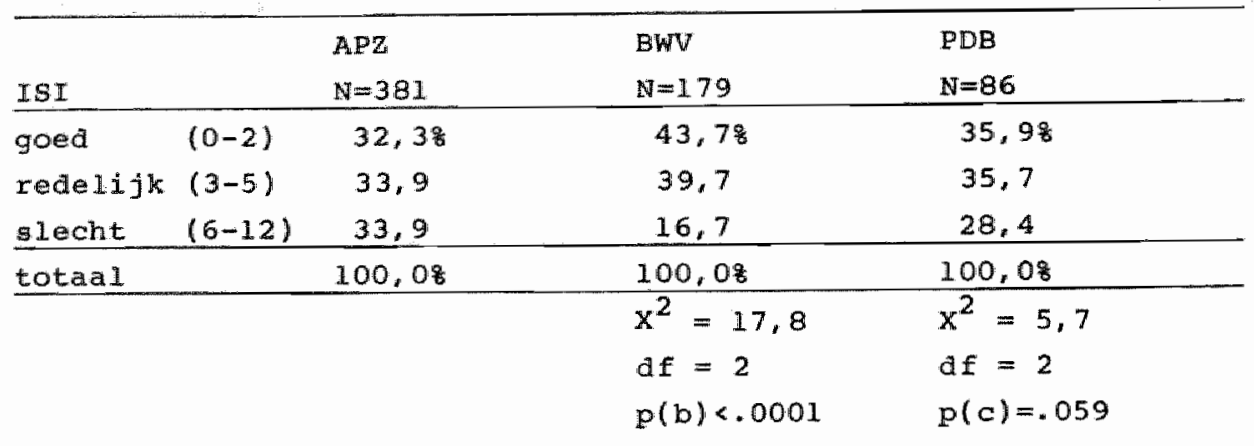

Ook in beschermende woonvormen en in psychiatrische dagbehandeling verbleven meer patiënten met een goede en redelijke ISI, dan in psychlatrische zlekenhuizen. voor de patiënten in psychiatrische dagbehandeling was dit verschil niet statistisch significant.

Het is mogelijk dat met de ISI-Index zowel verschil in patiëntengedrag werd gemeten als verschll in setting en zorgaanbod. Zowel wat betreft grootte. sfeer, activiteiten en personeel onderscheiden vele afdelingen en paviljoenen zich van bijvoorbeeld beschermende woonvormen. Een systematisch verschil ten aanzien van dagbehandelingspatiénten is verder dat het gedrag van deze patiënten 's avonds en in het weekend onderbelicht blijft.

Conclusie: alhoewel gerelativeerd door bovengenoemde kanttekeningen ten aanzlen van mogelijke settingeffecten, kan ook de derde hypothese als ondersteund worden aanvard. Patiënten die constructief en hulpvaardig deelnemen aan activiteiten op de afdeling (ISI) worden eerder positief beoordeeld voor vervangende zorg dan patienten die minder deelnemen an het interne sociale gebeuren. 


\subsubsection{Externe sociale integratie}

Het aantal contacten van lang opgenomen pationten in psychiatrische ziekenhuizen met het maatschappelijke leven buiten de instelling was beperkt. Meer dan de helft ondernam nooit of zeer zelden activiteiten zondex personele begeleiding buiten het instellingsterrein, zoals fietsen, wandelen, zwemmen e.d.. Een deel van de patiẻnten (45s) ging ook niet samen met personeel op stap. Driekwart van de patiënten bleef gedurende de weekends in het psychiatrische ziekenhuis, 158 ging éen keer in de maand het gehele weekend naar familie, vrienden of kennissen en 11 mér dan een keer per maand.

Het verrichten van betaald of onbetaald werk buiten ae instelling in de vorm vam bijvoorbeeld activiteiten in een sociale werkplats, een baan of klusjes, kwam incidenteel voor. Tweederde ging nooit of zeer zelden midden in de week op bezoek bij kennissen, vrienden of familie die buiten de instelling woonden. Wel kreeg 608 én keer of vaker in de maand bezoek van familieleden of vrienden/kennissen, en meer dan de helft deed wel eens boodschappen buiten het terrein. Eénderde van de patiènten ging bijna ieder jaar op vacantie. 
Tabe1 22: Aspecten van exteme sociale integratie bij lang opgenomen patienten in psychiatrische ziekenhuizen ( $N=381)$ : percentuele verdeling van antwoorden.

\begin{tabular}{|c|c|c|c|}
\hline Externe Sociale Integratie (ESI) & + & $+1-$ & - \\
\hline - werkt buiten de instelling & $5 \%$ & $2 \%$ & 938 \\
\hline - bezoekt bioscoop, theater, concert, kerk & 68 & $19 \%$ & $75 \%$ \\
\hline - blijft weekend bij anderen & 118 & 158 & 748 \\
\hline - gaat in de week op bezoek & 148 & $18 \%$ & $68 \%$ \\
\hline - schrijft brieven/kaarten & 118 & 268 & 638 \\
\hline - krijgt brieven/kaarten & $12 \%$ & $45 \%$ & 438 \\
\hline - wordt opgebela & 179 & 42 용 & 418 \\
\hline - activiteiten buiten (met personele & & & \\
\hline begeleiding) & 218 & 348 & $45 \%$ \\
\hline - activiteiten buiten (zonder personele & & & \\
\hline begeleiding) & 328 & 138 & 558 \\
\hline - krijgt bezoek & 208 & 418 & 398 \\
\hline - telefoneert zelf met anderen & 268 & $28 \%$ & 468 \\
\hline - praat met personeel over gebeurtenissen buiten & $19 \%$ & 488 & 338 \\
\hline - leest krant & 278 & $33 \%$ & 408 \\
\hline - leest tijdschriften & 278 & 348 & 398 \\
\hline - gaat op vacantie & 368 & 218 & 438 \\
\hline - boodschappen doen buiten & $38 \%$ & 20 乎 & 428 \\
\hline - doet mee aan uitstapjes & 318 & 458 & 248 \\
\hline - kijkt televisie & $50 \%$ & 398 & $\mathbb{1 1} 18$ \\
\hline - komt buiten terrein instelling & 378 & 508 & 138 \\
\hline
\end{tabular}

$+\quad$ social geintegreara

$+/-$ gedeeltelijk sociaal gexntegreerd

- = niet social geintegreerd

Patienten die volgens de hulpverleners in aanmerking kwamen voor vervangende zorg, hadden bilj 16 van de 19 genoemde aspecten aanzienlijk meex externe contacten dan de overige steekproefpatiënten van psychllatrische ziekenhuizen (toetsing a). Geen verschillen $(p>.05)$ werden gevonden voor het ontvangen van post, het 
krijgen var bezoek en het meedoen aan uitstapjes. ook de personen die na een langdurïge opname in een psychiatrisch ziekenhuis in beschermende woonvormen verbleven en psychiatrische dagbehandeling ontvingen, namen op bijna alle aspecten meer deel aan het matschappelijke gebeuren $(p<.05)$ dan de patienten die in psychiatrische ziekenhuizen verbleven (toetsing $b$ en $c$ ). Alleen ten aanzien van het ondernemen van activiteiten buiten de insteling, samen met het personeel, werden weinig verschillen gevonden.

H4: Naarmate de externe sociale integratie van lang opgenomen patienten geringer is, komen zij minder in aammerking voor vervangende zorg.

Tabel 23: Lang opgenomen patiënten in psychiatrische ziekenhuizen, naar mate van externe sociale integratie (ESI) en mogelijkheden van vervangende zorg; absoluut en percentages.

\begin{tabular}{|c|c|c|c|c|}
\hline ESI & $\begin{array}{l}\text { goed } \\
0-14 \\
\end{array}$ & $\begin{array}{l}\text { redelijk } \\
15-24\end{array}$ & $\begin{array}{l}\text { slecht } \\
25-40\end{array}$ & totaal \\
\hline \multicolumn{5}{|l|}{ vervangende } \\
\hline zorg-groep & (48욤) & $(458)$ & $(148)$ & $(308)$ \\
\hline overigen & 26 & 82 & 1.57 & 265 \\
\hline tataal & $50(1008)$ & $149(1008)$ & $18.2(1008)$ & $381(1008)$ \\
\hline
\end{tabular}

Terwijl ongeveer éenderde van de patiünten goed bleek deel te nemen (tabel 21) aan activiteiten binnen de instelling (ISI), was het aantal patiënten met een goede externe socilale integratie betrekkelijk gering. Van de 381 steekproefpatienten namen 50 , ofwel 13\%, in ruime mate deel aan het matschappelijke leven buiten de insteling.

Alhoewel de patiënten met een goede score op de EsI-index de grootste kans (48\%) hadden om voor vervangende zorg ingedeeld te 
worden, verschilde dit aandeel niet veel van de patienten met een redelijke mate van ESI. Ook van deze patienten werd nog 458 door beide hulpverleners geschikt geacht voor vervangende zorg. Vanaf een indexscore van 25 of meer tenslotte was de kans op vervangende zorg met 118 gering.

Tabel 24: Personen (1.0.p.) in algemene psychiatrische ziekenhuizen (APZ), beschermende woonvormen (BWV) en psychiatrische dagbehandeling (FDB) nar mate van externe sociale integratie: percentages.

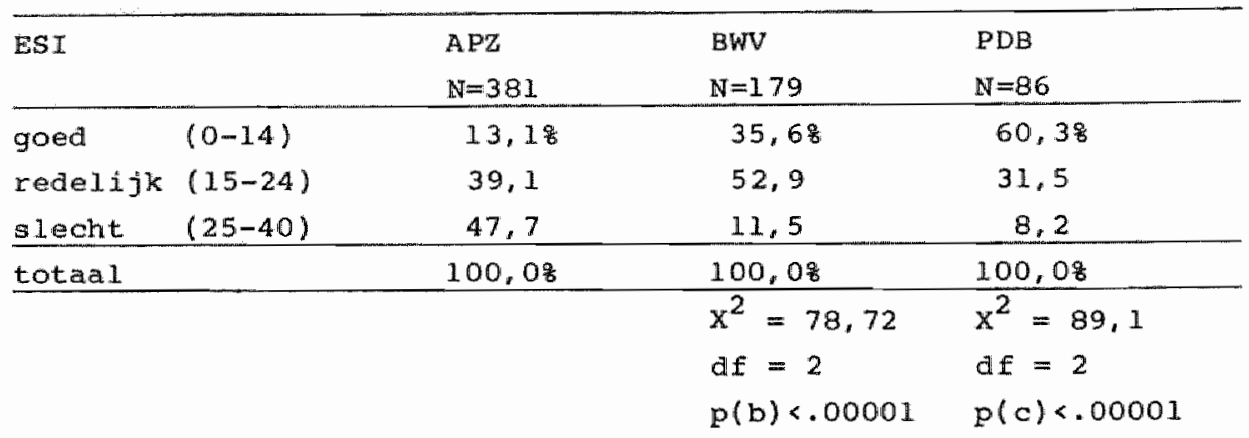

In vergelijking met klinisch opgenomen patiënten was de contactfrequentie en -intensiteit van personen in beschermende woonvormen en met psychiatrische dagbehandeling met gebeurtenissen en personen buiten de instelling aanzienlijk groter. Voor de personen in psychiatrische dagbehandeling lag de hogere ESI-score voor de hand, ondat allen buiten het ziekenhuisterrein wonen, en daar ook een gedeelte wan hun vrije tijd besteden. Ook de gemiddeld betere scores van de bewoners van beschermende woonvormen $\mathrm{zijn}$ onder andere verklaarbaar door de kleinschaligheid van deze instellingen en de lacatie in bevolkingskernem. Activiteiten buiten de instelling zonder begeleiding worden hierdoor gestimuleerd. 
Beschermende woonvormen verschilden van centra voor psychiatrische dagbehandeling door een grotere nadruk op het aspect "arbeid". Meer dan éenderde (39\%) van de bewoners had regelmatig werk, vooral in WSW-instellingen. Van de dagbehandelingspatiẻnten verrichtte 210 dikwijls betaald of onbetald werk.

De gevonden ESI-verschillen tussen enerzijds personen in beschermende woonvormen en dagbehandeling en anderzijas personen opgenomen in psychiatrische ziekenhuizem, konden echter niet geheel door het verschil in opvangsituatie worden verklaard "Het is aannemelijk dat ook gerichte selectle bij intake vam meer sociaal vaardige personen in beschermende woonvormen en dagbehandeling een belangrijke rol speelde.

Concluderend $\mathrm{kan}$ worden vastgesteld dat ook de vierde hypothese gedeeltelijk door bovenstaande resultaten wordt ondersteund. Het besluit om lang opgenomen patiënten voor vervangende zorg in aanmerking te laten komen is mede gebaseerd op het gegeven dat betrokkene over een redelijke mate van externe sociale integratie beschikt. Voor een positief oordeel over vervangende zorg echter is een goede ESI niet strikt noodzakelijk.

\subsection{Vaardigheden (multivariate analyse)}

Verwacht mag worden dat tussen de vier onderschetden vaardigheden onderlinge samenhang bestaat. Een hoge score op de ene index zal veelal gepaard gaan met een hoge score op een andere. En een lage scoxe op een index zal tevens overeenkomen met een lage score op een andere index. Zo is het aannemelijk dat lemand met een slechte zelfredzamheid wat betreft basale lichamelifke en psychische functies (BZR), ook over weinig mogelijkheden beschikt on gebruik te maken van openbaar vervoer, de telefoon e.d. (PSV) en beperkt deelneemt aan sociale activiteiten binnen (ISI) en buiten (ESI) de instelling.

Tabel 25 geeft per voorzieningensector door middel van linealre correlaties een indruk over de onderlinge samenhang van de vier vaardigheidsindices. 
Tabe1 25: Correlatiematxix van de vier vaardigheidsindices per vooxzieningensoort.

Paychiatrische ziekenhuizen $(N=381)$

\begin{tabular}{lllll}
\hline & BZR & PSV & ISI & ESI \\
\hline basale zelfredzaamheid (BZR) & 1.00 & & & \\
potentiéel sociale vaardigheden (PSV) & 0.58 & 1.00 & & \\
Linterne sociale integratie (ISI) & 0.56 & 0.63 & 1.00 & \\
externe sociale integratie (ESI) & 0.48 & 0.70 & 0.66 & 1.00 \\
\hline
\end{tabular}

Beachermende woonvormen $(\mathrm{N}=1.79)$

\begin{tabular}{lllll}
\hline & BZR & PSV & ISI & ESI \\
\hline basale zelfredzaamheid (BZR) & 1.00 & & & \\
potentiëel sociale vaardigheden (PSV) & 0.52 & 1.00 & & \\
interne sociale integratie (ISI) & 0.36 & 0.38 & 1.00 & \\
externe sociale integratie (ESI) & 0.28 & 0.55 & 0.50 & $\mathbb{1 1} .00$ \\
\hline
\end{tabular}

Psychiatrische dagbehandeling $(\mathrm{N}=86)$

\begin{tabular}{lllll}
\hline & BZR & PSV & ISI & ESI \\
\hline basale zelfredzaamheid (BZR) & 1.00 & & & \\
potentiëel sociale vaardigheden (FSV) & 0.45 & 1.00 & & \\
interne sociale integratie (ISI) & 0.32 & 0.53 & 1.00 & \\
externe sociale integratie (ESI) & 0.33 & 0.69 & 0.59 & 1.00 \\
\hline
\end{tabular}

De vaardigheden bij de patiënten in psychiatrische ziekenhuizen waren veelal hoog positief aan elkaar gerelateerd $(r>.50)$. Patiënten die op de ene index laag scoorden, scoorden veelal ook laag op andere indices, terwijl hoge indexscores vaak overeenkwamen met hoge scores op andere indices.

Voor de beschermende woonvormen en centra voor psychiatrische dagbehandeling waren de verbanden wel positief, max voor enkele varaigheden minder sterk. zo bleek de basale zelfredzaamheia van personen in deze voorzieningen minder gerelateerd te zijn aan de 
mate van interne en externe socialle integratie. Bij de pexsonen in beschermende woonvormen bestond tevens een minder sterk verband $(x=38)$ tussen de deelname aan activiteiten binnen de instelling (ISI) enerzijds en het beschikken over sociale vardigheden (PSV) anderzijds.

Het vervolg van dit hoofdstuk zal beperkt blijven tot de vaardigheldsgegevens voor patienten van psychiatrische ziekenhuizen (toetsing a). Nadat in hoofdstuk 12.1 . is nagegaan, hoe het vervangende zorg-oordeel van arts en verpleegkundige samenhangt met enkelvoudige vaardigheden (bivariate analyse), zal in dit hoofdstuk de vraag worden beantwoord, welke combinaties van scores op die vardigheden overeenkomen met een positief respectievelijk negatief plaatsingsoordeel (multivariate analyse). Daarbij is gebruik gemaakt van $z g n$. cross-classificatie van de vier variabelen.

\section{- Cross-classificatie}

Als basis voor de cross-classificatie diende een kruistabel bestaande uit de vier vaardigheden en het oordeel over vervangende zorg. Ten behoeve van de overzichtelijkheid was het noodzake$1 i j k$ om de vardigheidsvariabelen te dichotomiseren. Alsi a.fappunten voor BZR, PSV, ISI en ESI werd naAr aanleiding van de resultaten van de bivariate analyse gekozen voor de scores 3,2 , 3 en 25 . Indien de patiënt een lagere score had dan werd hij/zij als vardig op de index beschouwd, terwijl ari de afkapscore of en hogere score de betekenis "minder vaaralg" werd toegekend. De cross-classificatie van deze vier gedichotomiseerde indices resulteerde in $2^{4}=16$ mogelijke combinaties, warvan de resultaten voor 360 steekproefpatiënten zijn weergegeven (tabel 26 ). Van 21 var de 381 steekproefpatienten ontbrak op tenminste én van de indices een score. 
Tabel. 26: Classificatie van patienten die wel of niet voor verwangende zorg geschikt worden geacht op basis van basalle zelfredzamheid (BZR), potentieel sociale vardigheden (PSV), interne sociale integratie (ISI) en externe sociale integratie (ESI).

\begin{tabular}{|c|c|c|c|c|c|c|}
\hline $\begin{array}{l}x_{1} \\
B Z R\end{array}$ & $\begin{array}{l}x_{2} \\
\text { PSV }\end{array}$ & $\begin{array}{l}x_{3} \\
\text { ISI }\end{array}$ & $\begin{array}{l}x_{4} \\
\text { ESI }\end{array}$ & $\begin{array}{l}\text { T } \\
\text { Totaal } \\
\text { steekproeE }\end{array}$ & $\begin{array}{l}\text { V } \\
\text { Vervangende } \\
\text { zorg-groep }\end{array}$ & $\begin{array}{l}\text { W/T } x \text { loo } \\
\text { Percentage ver- } \\
\text { vangende zorg }\end{array}$ \\
\hline I. $0-2$ & $0-1$ & $0-2$ & $0-24$ & 53 & 33 & 64 욤 \\
\hline $2 \cdot 3+$ & $0-1$ & $0-2$ & $0-24$ & - & -- & -- \\
\hline 3. $0-2$ & $0-1$ & $3+$ & $0-24$ & 27 & 14 & 528 \\
\hline 4. $3+$ & $0-1$ & $3+$ & $0-24$ & 4 & 2 & $50 \%$ \\
\hline 5. $\quad 0-2$ & $2+$ & $0-2$ & $0-24$ & 34 & 17 & 508 \\
\hline $6.3 *$ & $2+$ & $0-2$ & $0-24$ & 4 & 2 & 508 \\
\hline $7 . \quad 0-2$ & $2+$ & $3+$ & $0-24$ & 60 & 15 & 258 \\
\hline 8. $3+$ & $2+$ & $3+$ & $a-24$ & 8 & 5 & 63 용 \\
\hline 9. $\quad 0-2$ & $0-1$ & $0-2$ & $25+$ & 6 & 3 & $50 \%$ \\
\hline 10. $3+$ & $0-1$ & $0-2$ & $25+$ & -- & -- & --- \\
\hline $11 \cdot 0-2$ & $0-1$ & $3+$ & $25+$ & 11 & 5 & 46 话 \\
\hline 12. $3+$ & $0-1$ & $3+$ & $25+$ & -- & -- & --- \\
\hline 13. $0-2$ & $2+$ & $0-2$ & $25+$ & 16 & 1 & 69 \\
\hline $14 \cdot 3+$ & $2+$ & $0-2$ & $25+$ & 2 & -- & 08 \\
\hline 15. $0-2$ & $2+$ & $3+$ & $25+$ & 64 & 12 & 198 \\
\hline 16. $3+$ & $2+$ & $3+$ & $25+$ & 71 & 4 & 68 \\
\hline Totaa 1 & & & & 360 & 113 & $31 \%$ \\
\hline
\end{tabular}

Welke combinaties van de vier varaigheden komen nu in de steekproef het meeste voor, en welke vaardigheidspatronen komen het meest overeen met een positief oordeel over vervangende zorg?

De bespreking van de resultaten van tabel 26 zal beperkt blijwen tot de vaardighelispatronen die voor meer dan loo van de patiënter golden.

Eénvijfae ofwel 71 patiënten van de steekproef hadden enige of ernstige beperkingen op alle vaardigheidsvariabelen (patroon 16). 
Slechts 6 van deze patiënten werd door zowel de hoofdbehandelaar als de verpleegkundige geindiceerd voor vervangende zorg. Andere 64 patiënten waren goed zelfredzaam, mar zowel beperkt in hum (potentieel) sociale vaardigheden als ook in de mate van interne en externe sociale integratie (patroon 15). Ook de patiènten met dit vaaraigheidspatroon kwamen nog betrekkelijk weinlg (19\%) in aanmerking voor vervangende zorg.

Bilj 60 patiënten ging een goede basale zelfredzaamheid en een goede externe sociale integratie gepara met matige scores op de PSV- en ISI-index (patroon 7). Een kwart van deze patienten (25) werd ingedeeld voor vervangende zorg.

Tenslotte hadden 53 patiënten goede scores op alle viex vaaraighellasvariabelen (patroon I). Ongeveer tweederde (64:) van de patienten met en dergelijk vaardigheidspatroon werd geschikt geacht voor vervangende zorg.

Aan de hand van de gegevens van tabel $26 \mathrm{kan}$ worden nagegaan, of de variabelen interne of externe sociale integratie nog een extra bijdrage leveren voor het aordeel van de hulpverleners over wervangende zorg, als met de invloed wan de variabelen BZR en PSV reeds rekening is gehouden. De volgende twee vragen kunnen in dit verband worden gesteld:

(1) als lang opgenomen patiënten niet van elkaar verschillen, wat betreft BZR en PSV, worden dan patiẻnten die veel deelnemen aan activiteiten binnen de instelling (ISI) eerder voor vervangende zorg ingedeeld dan patiënten die mindex aan activiteiten binnen de instelling participeren? En:

(2) als lang opgenomen patienten niet verschilden, wat betreft BZR en PSV, worden dan patiëten die veel activiteiten ondermemen buiten de instelling (ESI), eerder voor vervangende zorg ingedeeld dan patienten die minder vaak dergelijke activiteiten ondernemen? 
In verband met de woorgaande uragen kan de irvloed van de variabelen interne en externe sociale integratie bestudeerd worden voox een arietal subgroepen, namelijk:

- patienten die zelfredzaam en sociaal vaarig zijn (patronen $\mathbb{1}$ 3,9 en $11 ; M=97$ ):

- patiénten die zelfredzaam maar beperkt sociaal vaardig zijn (patronen 5, 7, 13 en 15; $N=174$ );

- patiénten die beperkt zelfredzaam en beperkt sociaal vaaraig zijn (patronen 6, 8, 14 en 16; $\mathrm{N}=85$ ).

De combinatie van geringe zelfredzaamheid en goede sociale vaardigheden (patronen 2, 4, 10 en 12) - niet logische patronen als men uitgaat van een goede BZR als noodzakelijke voorwaarde voor gaede PSV - kwam bij 4 patiënten voor. Voor deze subgroep is de analyse niet uitgevoerd, gezien het beperkte aantal waarnemingen.

\section{Zelfredzame en sociaal vardige patienten}

Lang opgenomen patienten die goed zelfredzaam en goed sociaal vardig waren, werden eerder voor vervangende zorg ingedeeld als zij tevens veel deelnamen a an activiteiten binmen (ISI) of buiten de Instelling (ESI). Vooruitlopend op de resultaten voor de twee andere subgroepen $k a n$ worden opgemerkt dat deze conclusie ook geldt voor patiënten met meer beperkingen in zelfredzaamheid en sociale vardigheden.

Tabel 27: goed zelfredzame (BZRe3) en siocian

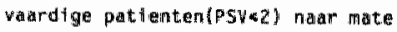
van interne sactale integratte(ISI) en oordee 1 over werkangende zarg.
Tabel 28: goed zelfredzame (8zR43) en sociaal wadrdige patientem(PSV<) naar mate wan exterme sacilale integratie(ESI) en oordeel ower varwangende zorg.
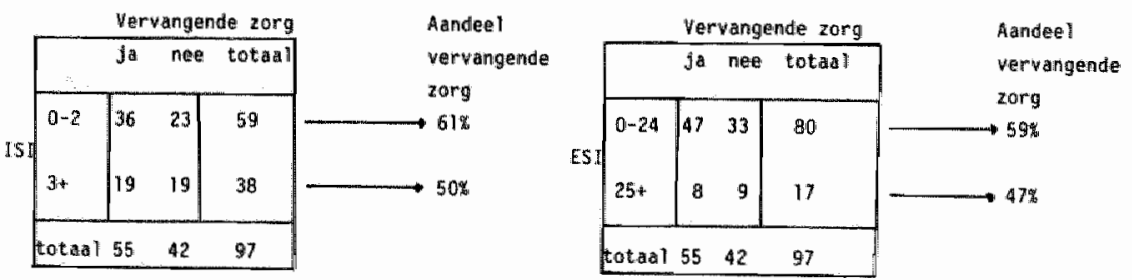
U1t de tabelien 27 en 28 blijkt overigens wel dat de variabelen ISI en ESI bij deze groep van zelfredzame en sociaal varaige patienten niet al te veel meer bijdragen tot een positief oordeel over vervangende zorg. Ook de zelfredzame en social vaardige patiëten die relatief weinig deelnamen aan activiteiten binnen de instelling (ISI) werden nog voor 50 of ingedeeld voor vervangende zorg (tabel 27). Van de patienten met hetzelfde varaigheidsniveau, mar met een goede deelname aan activiteiten binmen de instelling kwam 61 웅 voor vervangende zorg in aanmerking. De resultaten voor externe sociale integratie (tabel 28) geven eenzelfae beeld te zien.

\section{Zelfredzame mar beperkt sociaal vaardige patiënten}

Ook bij de grote groep lang opgenomen patiënten met een goede zelfredzaamheid mar met beperkte saciale vaardigheden $(\mathbb{N}=174)$ valt op dat personen die goed deelnamen aan activiteiten binnen of buiten de instelling, eerder werden ingedeeld voor vervangende zorg.

Tabell 29: goed zelfredzame maxr minder social vaiardige patienten(PSY>1) naar mate valn intierne sociale integratie(ISI) ien oordeet aver wervangende zorg.
Tabe 1 30: goed zelfredizame maar minder 50ct al wardige patientem(BSW wan axterne soctale integratie(ESI) en pordeel over vervangende zorg.

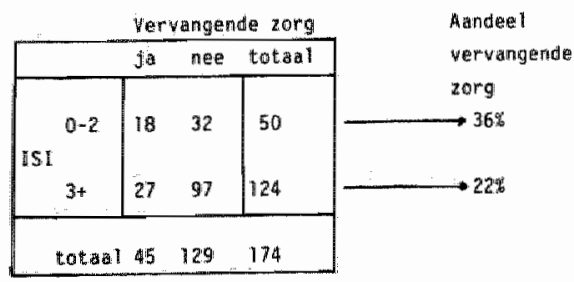

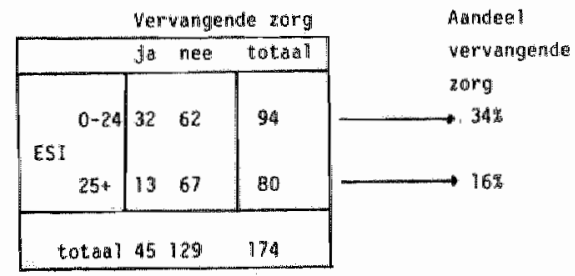


Bij een goede ISI werd 36 van de patienten geschikt geacht voor vervangende zorg tegenover 22 van de patienten met minder goede ISI (tabel 29). Bij de ESI-Index waren de respectievelijke percentages 348 en $16 \%$ (tabiel 30 ).

Ahoewel de variabelen ISI en ESI van belang zijn voor de oordeelsworming van hulpverleners over ontslag en vervangende zorg, kan natr aanleiding van de resultaten van de tabelien 27 en 28 toch worden gewezen op de aanzienlijk grotere invloed van de variabele "potentieel sociale vaardigheden" op het oordeel. Al hadden sociaal vaardige patiënten weinig contacten en activiteiter binnen of buiten de instelling, dan nog werden zij eerder voor vervangende zorg aangemerkt dan patienten die wel dergelijke contacten en activiteiten hadden, maar over slechtere sociale vaardigheden (PSV) beschikten.

\section{Beperkt zelfredzame en beperkt sociaal vaardige patiënten}

Van de patiënten die beperkingen hadden wat betreft zelfredzaamheid en sociale varaigheden, namen slechts enkele patiênten veel. deel aan activiteiten binnen of buiten de instelling. Van de 85 patiënten met een geringe $B Z R$ en een geringe PSV waren 6 (7\%) goed geintegreerd in het sociale leven binnen de instelling en 12 patiënten (148) in het sociale leven buiten de insteling.

Tabel 31: beperkt zelfredzame(BzR>2) en beperkt: saciaal vaardige(PSW>I) patienten naar mate van tinterne soclale integratie(IsI) en gordeel ower verwangende zorg.

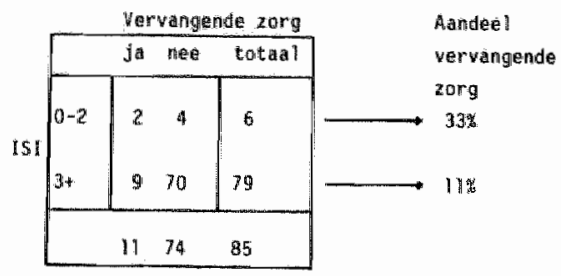

Tabel 32: beperkt zelfiredzame (BZR $>2$ ) en beperkt sociaal vaardige(PSW>1) patienten naar mate wan externe sociale integratie(ESI) en cordeel over verwangende zorg.

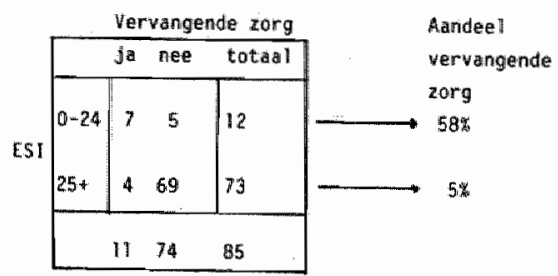


De kleine groep van patienten die ondanks hun beperkingen intensief deelnam aan activeiten binnen of buiten de instelling werd, ook eerdex voor vervangende zorg ingedeeld. Dit gold vooral voor patienten met veel contacten buiten de instelling (ESI). Voor deze patienten zijn de verschillen statistisch significant bilj éénzïjdige toetsing door middel van Fisher's exact test.

Resumerend: Uit de gegevens van de cross-classificatie wordt auidelijk dat iedere vaardigheidsvariabele apart bijaraagt aan een positief oordeel over vervangende zorg. De extra bijarage van iedere variabele wordt duidelijk in de sequentie $B R^{+} \longrightarrow \mathrm{BZR}^{*}$ \& $\mathrm{PSV}^{+} \rightarrow \mathrm{BZR}^{+} \& \mathrm{PSV}^{+} \& \mathrm{ISI}^{+}$, mar ook in de sequentie $\mathrm{BZR}^{+} \rightarrow \mathrm{BzR}^{+}$\& $\mathrm{PSV}^{+} \rightarrow \mathrm{BZR}^{+} \& \mathrm{PSV}^{+} \& \mathrm{ESI}^{+}$. Patienten die alleen zelfredzaam zijn, hebben minder kans, dan patiënten aie zelfredzaam en soclaal vardig zijn. En patiênten die zelfredzaam en sociaal vaaraig zijn hebben wederom minder kans op vervangende zorg dan patienten met een varaigheidspatron van zelfredzamheid, sociad-vaaralgheld en interne of externe sociale integratie.

De variabele basale zelfredzamheid alleen vertelt nog niet veel over de kans op vervangende zorg. Van de patiënten die op alle vaardigheden enige problemen hadden, werd 6 in ingedeeld voor vervangende zorg (patroon 16), terwijl de zelfredzame patienten met beperkingen op de overige varaigheiasvariabelen voor $19 \%$ positief werden beoordeeld voor vervangende zorg (patroon 15). Het positieve oordeel voor vervangende zorg bleek vooral samen te hangen met goede (potentieel) sociale vaardigheden zoals zelfstandig kunnen telefoneren, boodschappen doen, maltijden bereiden en gebruik maken van openbaar vervoer. Patiënten die op de psv-index een score hadaen van $<2$, werden ongeacht de scores op andere vaardigheidsvariabelen tenmingte voor 468 ingedeeld voor vervangende zorg (patroon 11 en 4).

Indien patiẻnten zowel zelfredzaam en sociaal vaardig waren, maar tevens relatief veel contact hadden met het gebeuren binnen (ISI) of buiten (ESI) de instelling (patroon 9 en 3), leidde dit tot een geringe verhoging van het vervangende zorgpercentage (50\% resp. 52 t). 
De patienten tenslotte met een optimal waardigheidspatroon $\left(\mathrm{BZR}^{*}\right.$ \& PSV $^{+}$\&SI ISSI $^{+}$) hadden met 64 g ook de beste kansen om door de hulpverleners voor vervangende zorg te worden ingedeeld (patroon 1).

\subsection{Psychiatrische diagnose}

In de literatuur werden ten aanzien van twee psychiatrischdiagnostische hoofdgroepen aanwijzingen gevonden dat ze van invloed zouden zijn op het besluit om patiënten niet voor vervangende zorg in a anmerking te laten komen (hfdst. 6.1.2.). Zowel de patianten met organische psychische stoornissen als met schizofrene beelden zouden minder kans maken op vervangende zorg. Ten aanzien van patilënten van de eerste diagnosecategorie werd de volgende hypothese geformuleerd:

H5: Als lang opgenomen patiënten een organische psychische stoornis hebben, komen zij minder voor wervangende zorg in aammerking dan patiënten met andere psychische stoornissen.

Het aspect "organische psychische stoornis" bleef in ait onderzoek beperkt tot de hoofdgroepen passagère organische psychotische aandoeningen (293), overige organische psychotische aandoeningen (294) en specifieke niet psychotische stoornissen ten gevolge van arganische hersenbeschadiging (310) van de ICD 9/DSM III. Patiënten met een alcohol of drugpsychose (291 292) werden ingedeela bij het diagnosecluster "stoornis bij alcohol- of druggebruik", conform de presentatie van diagnosegegevens van de landelijke patiëntenregistratie (PIGG) wan de Geneeskundige Hoofdinspectie voor de Geestelijke Volksgezondheid. Patienten met de diagnose seniele of preseniele dementie vielen buiten het bestek van ait onderzoek. 
Tabie 1 33: Lang opgenomen patiênten in psychiatrische ziekenhuizem maar diagnose organische psychische stoornis vs, overige diagnosen en mogelijkheden voor vervangende zorg: absoluut en percentages.

\begin{tabular}{|c|c|c|c|}
\hline \multirow{4}{*}{ Diagnose } & \multicolumn{3}{|l|}{ organische } \\
\hline & psychische & averige & \\
\hline & stoornis & diagnose- & \\
\hline & $(293,294,310)$ & groepen & totaal \\
\hline vervangende zorggroep & $8 \quad(388)$ & $108 \quad(308)$ & $116(308)$ \\
\hline overige patiënten & 13 & 252 & 265 \\
\hline totaal & $21(1008)$ & $360(1008)$ & 381 (1008) \\
\hline
\end{tabular}

Bovenstaande resultaten (tabel 33) zijn niet in overeenstemming met de strekking van de hypothese. In de vervangende zorg-groep waren de patiënten met een organische psychische stoornis zelfs lets oververtegenwoordigd. De stelling dat patiënten met een organische stoornis minder voor vervangende zorg in ammerking komen, wordt dus niet ondersteund.

Tabe1 34 : Personen (1.0.p.) in psychiatrische ziekenhuizen (APZ). beschermende woonvormen (BWV) en psychiatrische dagbehandeling (PDB) naar diagnose organische psychische stoornis vs. overige diagnosen; percentages.

\begin{tabular}{lccc}
\hline Diagnose & $\begin{array}{c}\text { APZ } \\
(\mathbb{N}=381)\end{array}$ & $\begin{array}{c}B W V \\
(N=179)\end{array}$ & $\begin{array}{c}\text { PDB } \\
(\mathbb{N}=86)\end{array}$ \\
\hline arganische psychische stoormis & $5,5 \%$ & $4,7 \%$ & 3,58
\end{tabular}

\begin{tabular}{llll} 
overige diagnose & 94,58 & 95,38 & 96,58 \\
\hline total & 100,08 & 100,09 & 100,08 \\
\hline & $x^{2}=0,28 \quad x^{2}=0,58$ \\
& df $=1$ & df $=1$ \\
& $p(b)=.6824 \quad \mathrm{p}(\mathrm{c})=.4874$
\end{tabular}


ook bij vergelijking met de steekproefpersonen in beschermende woonvormen en psychiatrische dagbehandeling (tabel 34) zijn geen statistuch significante verschillen te constateren (toetsing b en c). De diagnose "organische psychische stoornis" werd in deze voorzieningen iets minder gesteld, maar de verschilien bevinden zich wat betreft grootte-orde binnen de toevalsfluctuaties van steekproeftrekking *

Conclusie: Gezien de resultaten van de arie toetsingen tezamen wordt hypothese 5 niet ondersteund. De diagnose "organische psychische stoornis" was bij de besluitvorming over vervangende van weinig betekenis.

Ook een andere diagnostische groep wordt vaak in verband gebracht met een slechte ontslag- en vervangende zorg-prognose, namelijk patienten met de diagnose schizofrenie. In het onderzoek werd alleen de hoofdgroep "schizofrene stoornis" (ICD 9, 295) gescoord zonder verdere onderverdeling/specificatie. Zo was niet bekend of betrokken patiènt wel of niet op het tijdstip van beoordeling in een acute psychotische fase verkeerde, of dat er sprake was van latente of restverschijnselen ("defektschizofrenie") van een psychose. Tevens werd niet naar het aantal en de soort psychiatrische symptomen gevraagd.

De verwachting in het onderzoek ten aanzien van deze diagnostische groep was als volgt:

H6: Als lang opgenomen patiënten de diagnose schizofrenie hebben, komen zij minder voor vervangende zorg in aanmerking dan patiënten met andere psychische stoornissen. 
Tabe1 35: Lang opgenomen patiënten in psychiatrische ziekenhüzen naar diagnose schizofrenie vs . overige diagnosen en mogelijkheden voor vervangende zorg: absoluut en percentages.

\begin{tabular}{lccccc}
\hline & \multicolumn{3}{c}{ schizofrenie overige diagno- } \\
diagnose & $(\operatorname{ICD} 9,295)$ & se-groepen & totaa 1 \\
\hline vervangende zorggroep & $43(238)$ & $73 \quad(388)$ & $116(308)$ \\
overige patiënten & 147 & 118 & 265 \\
\hline total & $190(1008)$ & $191(1008)$ & $381(1008)$ \\
\hline & $\mathrm{x}^{2}=11,07 ;$ df $=1 ; \mathrm{p}(\mathrm{a})<.001$
\end{tabular}

Deze hypothese werd bij eerste toetsing bevestigd. Patiënten met de diagnose schizofrenie waren daadwerkelijk minder vertegenwoordigd in de vervangende zorg-groep dan patienten met andere alagnosen. In de vervangende zorg-groep had ongeveer éénderde (37\%) van de patiënten de diagnose schizofrenie, terwijl van de overige steekproefpatiënten meer dan de helft (56\%) als schizofreen was gediagnostiseerd.

Deze resultaten geven dus bij eerste toetsing steun aan de hypothese dat de indeling voor vervangende zorg negatief gerelateerd is aan de diagnose schizofrenie. Patiënten met deze aliagnose kwamen minder voor vervangende zorg in aanmerking.

Tabel 36: Personer (1.0.p.) in psychiatrische ziekenhulizen (APZ), beschermende woonvormen (BWV) en psychiatrische dagbehandeling (PDB) naar diagnose schizofrenie vs. overige diagnosen; percentages.

\begin{tabular}{lccc}
\hline Diagnose & $\begin{array}{c}\mathrm{APZ} \\
(\mathrm{N}=381)\end{array}$ & $\begin{array}{l}\mathrm{BWV} \\
(\mathrm{N}=179)\end{array}$ & $\begin{array}{l}\mathrm{PDB} \\
(\mathrm{N}=86)\end{array}$ \\
\hline schizofxenie & 49,98 & $38,4 \%$ & $32,9 \%$ \\
overige diagnose & 50,1 & 61,6 & 67,1 \\
\hline total & 100,08 & $100,0 \%$ & $100,0 \%$ \\
\hline & & $\mathrm{x}^{2}=6,29$ & $\mathrm{x}^{2}=8,38$ \\
& & $\mathrm{df}=1$ & $\mathrm{df}=1$ \\
& & $\mathrm{p}(\mathrm{b})<.05$ & $\mathrm{p}(\mathrm{c})<.01$
\end{tabular}


De wergelijking van patiënten in psychiatrische ziekenhuizen met zowel bewoners van beschermende woonvormen als dagbehandelingspatiênten nax diagnose (tabel 36) gaf hetzelfde beeld te zien. De steekproefpersonen in deze vervangende zorgvormen hadden aanzienlijk minder de diagnose "schizofrenie".

Bij de interpretatie van de resultaten van tabel 34 en 36 is enige voorzichtigheid geboden. Zo zal rekening moeten worden gehouden met de mogelijkheid van een systematisch verschil in het stellen van een diagnose, bijvoorbeela bij patienten in psychiatrische dagbehandeling. Bij de bewoners van beschermende woonvormen was veelal geen actuele diagnose gesteld, daar de zorgverlening in deze instellingen gericht is op woonrevalidatie en begeleiding/steun en niet op behandeling. Wit de toelichtingen van medewerkers van de beschermende woonvormen op de diagnosevraag bleek dat zowel gebruik werd gemakt van informatie van en Riagg-psychiatex, als ook van diagnostische gegevens bij ontsiag uit de kliniek. De bron van informatle, het soort informatie. maar tevens de actualiteit van de informatie ten aanzien van de diagnose was dus voor de beschermende woonvormen meer heterogeen, dan het geval. was voor psychiatrische ziekenhuizen en centra voor psychiatrische dagbehandeling.

Conclusie: ondanks bovenstaande kanttekeningen lijken de resultaten van de drie toetsingen - in onderling verband beschouwd - de geldigheid van de hypothese te ondersteunen. Lang opgenomen patiẻnten met de diagnose "schizofrenie" komen minder in aanmerking voor vervangende zorg, dan patiënten met een andere aliagnose.

\section{4. Gevaar voor zichzelf en anderen}

Uit de literatuur komt nax voren dat agressief gedrag en surcidaal gedrag belangrijke redenen zijn on patiënten niet voor vervangende zorg of ontslag in aanmerking te laten komen. Ten aanzien van de vraag, of dit ook geldt voor lang opgenomen patienten in Nederlandse psychiatrische ziekenhuizen, zal de andacht eerst worden gericht op agressief gedrag, zoals verwoord in hypothese 7 . 
H7: Naarmate lang opgenomen patiënten agressiever zijn. komen zij minder in aanmerking voor vervangende zorg.

Tabe1 37 : Lang opgenomen patiënten in psychiatrische ziekenhuizen naar mate van agressie en mogelijkheden voor vervangende zorg; absoluut en percentages.

\begin{tabular}{|c|c|c|c|c|}
\hline $\mathrm{AGR}$ & $\begin{array}{l}\text { niet } \\
(0-1)\end{array}$ & $\begin{array}{l}\text { soms } \\
(2-3)\end{array}$ & $\begin{array}{l}\text { veel } \\
(4-8)\end{array}$ & totaal \\
\hline \multicolumn{5}{|l|}{ vervangende } \\
\hline zorg groep & $(348)$ & $(338)$ & $(1.78)$ & $(308)$ \\
\hline overige patiënten & 133 & 65 & 67 & 265 \\
\hline totaa1 & $203(1008)$ & 97 (1008) & $81(1008)$ & $381(1008)$ \\
\hline
\end{tabular}

De resultaten van tabel 37 lijken deze hypothese te bevestigen. Van de patienten net veel agressief gedrag werd een aanzienlijk kleiner aandeel (17\%) voor vervangende zorg ingedeeld, dan patïënten met minder agressief gedrag (33\%). Pas bij een AGR-score van 4 of meer kon overigens een duidelijk verschil worden vastgesteld. Zo kwamen patiënten die soms agressief waren, in dezelfde mate in aanmerking voor vervangende zorg als patiënten die nauwelijks agressief gedrag vertoonden.

Tabel 38: Personen (1.0.p.) in psychiatrische ziekenhuizen (APZ), beschermende woomvormen (BWV) en psychiatrische dagbehandeling (PDB) naar mate van agressie; percentages.

\begin{tabular}{|c|c|c|c|c|}
\hline AGR & & $\mathrm{APZ}$ & BWV & $\mathrm{PDB}$ \\
\hline niet & $(0-1)$ & 53,28 & 58,78 & $67,1 \%$ \\
\hline soms & $(2-3)$ & 25,4 & 21,2 & 21,2 \\
\hline vee $\mathbb{1}$ & $(4-6)$ & 17,5 & 18,4 & 11,8 \\
\hline zeer veel & $(7-8)$ & 4,0 & 1,7 & - \\
\hline \multicolumn{2}{|c|}{ totaal } & 100,08 & $100,0 \%$ & 100,08 \\
\hline$-\ldots$ & & & $\begin{array}{l}x^{2}=3,58 \\
d f=3 \\
p(b)=.310\end{array}$ & $\begin{array}{l}x^{2}=7.65 \\
d f=3 \\
p(c)=.054\end{array}$ \\
\hline
\end{tabular}


De steekproefpersonen in beschermende woonvormen en psychiatrische dagbehandeling vertoonden iets minder agressief gedrag (tabel 38). Toch waren de vexschillen niet erg opvallend. Zo kwam in de beschermende woonvormen bijna evenveel agressief gedrag voor als bij de lang opgenomen patienten in psychiatrische ziekenhuizen. Zeer agressief gedrag kwam bij dagbehandelingspatiënten in het geheel niet voor.

Concluderend kan worden opgemerkt dat hypothese 7 alleen gedeeltelijk wordt bevestigd. Pas bij ernstige vormen van agressief gedrag lijken lang opgenomen patiënten in mindere mate in aanmerking te konen voor vervangende zorg. Agressief gedrag kwam in bijna gelijke omvang als bij bewoners van psychiatrische ziekenthizizen voor bij bewoners van beschermende woonvormen, die voor hun verbiljf aldaar langdurig waren opgenomen geweest in psychiatrische ziekenhuizen. De dagbehandelingssituatie lijkt minder geschikt en toegerust te zijn voor de opvang van patienten met ernstige vormen van agressief gedrag.

Bij de bespreking van de literatuur werd geconstateerd dat niet alleen agressie gericht op anderen, maar tevens agressie gericht op de eigen persoon, voldoende aanleiding is om personen niet in aanmexking te laten komen voor vervangende zorg. Deze aanname resulteerde in de volgende veronderstelling.

H8: Naarmate lang opgenomen patiënten suicidaal zijn, komen zij minder in aanmerking voor vervangende zorg.

Tabel 39: Lang opgenomen patiënten in psychiatrische ziekenhuizen naar mate van suicidegeneigdheid en mogelijkheden voor vervangende zorg; absoluut en percentages.

\begin{tabular}{|c|c|c|c|c|}
\hline SUI & $\begin{array}{c}\text { niet } \\
(0-1)\end{array}$ & $\begin{array}{l}\text { soms } \\
(2-3)\end{array}$ & $\begin{array}{l}\text { veel } \\
(4-6)\end{array}$ & totaal \\
\hline \multicolumn{5}{|l|}{ vervangende } \\
\hline zorg groep & $(308)$ & $(398)$ & $(508)$ & $(308)$ \\
\hline overige patiënten & 252 & 11 & 2 & 265 \\
\hline totaal & $359(1008)$ & $18(1008)$ & $4(1008)$ & $381(1008)$ \\
\hline
\end{tabular}


Suicideneigingen en -dreigingen kwamen bij lang opgenomen patienten betrekkelijk zelden voor (tabel 39). Gedurende een periade van drie manden was door 48 van de patiënten gedreiga met sulcide, of was een poging tot suicide ondernomen. ook kwam suicideproblematiek niet aanzienlijk meer voor bij patiënten warvoor geen vervangende zorg mogelijk werd geacht. Het was zelfs zo dat patiënten met suicideproblemen eerder door hun hulpverleners voor vervangende zorg werden ingedeeld dan patiènten zonder suicideproblemen. Dit onverwachte resultaat was statistisch gezien niet significant.

Tabel 40: Personen (1.0.p.) in psychiatrische ziekenhuizen (APZ), beschermende woonvormen (BWV) en psychiatrische dagbehandeling (PDB) naar mate van suicidegeneigdheld; percentages *

\begin{tabular}{lccc}
\hline SUI & $\begin{array}{c}\text { APZ } \\
(\mathrm{N}=381)\end{array}$ & $\begin{array}{c}\text { BWV } \\
(\mathrm{N}=179)\end{array}$ & $\begin{array}{l}\text { PDB } \\
(\mathrm{N}=86)\end{array}$ \\
\hline niet $(\mathrm{O}-1)$ & 94,28 & 98,98 & 95,38 \\
soms $(2-3)$ & 4,8 & 1,1 & 4,7 \\
vee1 $(4-6)$ & 1,0 & - in & - \\
\hline totaal & 100,08 & 100,08 & 100,08 \\
\hline & & $\mathrm{x}^{2}=6,67$ & $\mathrm{x}^{2}=0,91$ \\
& & $\mathrm{df}=2$ & $\mathrm{df}=2$ \\
& & $\mathrm{p}(\mathrm{b}) \times .05$ & $\mathrm{p}(\mathrm{c})=.635$
\end{tabular}

ook de informatie over de dagbehandelingspatiënten ondersteunde de hypothese niet (toetsing c). Evenals bij klinisch opgenomen patiënten vertoonden enkele patiënten in dagbehandeling soms sulcideneigingen (tabel 40). In de beschermende woorvormen daarentegen kwam suicidaal gedrag statistisch significant minder voor (toetsing b). Voor deze instellingen lijkt het dreigen met sulcide of een ondernomen poging een contra-indicatie te zijn voor intake of verder verblijf. 
Conclusie: de algemene strekking van hypothese 8 werd niet bevestigd. Bij de indicatiestelling van lang opgenomen patiënten voor vervangende zorg door intramurale hulpverleners leek suIcidaal gedrag geen belangrijke rol te spelen. Ook bij. de steekproefpatienter in dagbehandeling: kwamen suicialiteitsproblemen even weinig woor als bij patienten in 24-uurs klinische zorg. In de beschermende woonvormen daarentegen verbleven nauwelijks pexsonen met sulcidaliteitsproblemen. Alleen voor deze instellingen werd de hypothese bevestigd.

\subsection{Leeftida en de hypothesen $1 \mathrm{t} / \mathrm{m} . \mathrm{B}$}

In de voorgaande hoofdstukken werden de vaardigheids- en gevaaraspecten besproken zonder nuancerende en relativerende opmerkingen over de mogelijke invloed van de leeftijd van de betrokken patient op het oordeel van hulpverleners. Het is echter mogelijk dat de gevonden relatie tussen vaadigheden en het oordeel over vervangende zorg gedeeltelijk verklaard wordt door bijvoorbeeld leeftijd. Indien jongeren zowel over betere vaardigheden beschikken als ook eerder positief worden beoordeeld voor vervangende zorg, dan fungeert leeftid als een confounding variabele. Om na te gaan, welk effect precies de variabele leeftija heeft voor de veronderstelde relatie, zal dan voor de invloed van deze variabele gecontroleerd moeten worden. Een mogelijkheid hiertoe is stratificatie, - herhalen van de analyse, max dan voor jongeren en ouderen apart.

De controle op confounding wordt noodzakelijk, als een sterke relatie ls aangetoond tussen de leeftija van patiênten en het in aammerking komen van patiënten voor vervangende zorg. Eerst zal dan ook deze relatie worden onderzacht.

Biy de start van het onderzoek werd de richting van het verband a angegeven. De veronderstelling was dat met de toename van de leeftija de kans op vervangende zorg zou dalen.

H9: Naarmate lang opgenomen patiënten ouder zijn, komen zij minder in anmerking voor vervangende zorg. 
Tabel 41: Lang opgenomen patiënten in psychiatrische ziekenhuizen nat leeftijd en mogelijkheden voor vervangende zorg; absoluut en percentages.

\begin{tabular}{|c|c|c|c|c|c|c|c|}
\hline Leeftija & $<45$ & jaar & $45-64$ jaar & $>65$ & jaar & \multicolumn{2}{|c|}{ totaal } \\
\hline \multicolumn{8}{|l|}{ vervangende } \\
\hline zorg groep & 54 & $(528)$ & $(318)$ & 15 & $(128)$ & 116 & $(308)$ \\
\hline overige patiënten & 49 & & 106 & 110 & & 265 & \\
\hline totaal & 103 & $(1.008)$ & 153 $(1008)$ & 125 & $(1008)$ & 381 & $(1008)$ \\
\hline
\end{tabular}

De resultaten van tabel 41 ondersteunen de hypothese. Jongere patienten werden eerder positief geindiceerd door hun hulpverleners voor vervangende zorg dan oudere patiënten. Zo werd voor meer dan de helft van de patiënten jonger dan 45 jaar vervangende zorg mogelijke geacht. Bij de bejaarde patiënten was dit aandeel gereduceerd tot $12 \%$

Tabel 42: Personen (1.0.p.) in psychiatrische ziekenhuizen (APZ), beschermende woonvormen (BWV) en psychiatrische dagbehandeling (PDB) naar leeftijd; percentages.

\begin{tabular}{|c|c|c|c|}
\hline Leeftüjd & $\begin{array}{l}\mathrm{APZ} \\
(\mathbb{N}=381)\end{array}$ & $\begin{array}{l}\text { BWV } \\
(\mathrm{N}=179)\end{array}$ & $\begin{array}{l}\mathrm{PDB} \\
(\mathrm{N}=86)\end{array}$ \\
\hline$\leq 25$ & 1,68 & - & 4,88 \\
\hline $25-34$ & 8,1 & 10,7 & 25,0 \\
\hline $35-44$ & 17,1 & 13,0 & 26,2 \\
\hline $45-54$ & 18,4 & 22,0 & 19,0 \\
\hline $55-64$ & 22,0 & 29,4 & 13,1 \\
\hline $65-74$ & 18,1 & 18,1 & 11,9 \\
\hline $75-84$ & 12,9 & 5,1 & - \\
\hline$>85$ & 1,8 & 1,7 & $-\quad-$ \\
\hline \multirow[t]{2}{*}{ totaal } & 100,08 & 100,08 & $100,0 \%$ \\
\hline & & $\begin{array}{l}x^{2}=15.50 \\
\text { dif }=7 \\
p(b)<.05\end{array}$ & $\begin{array}{l}x^{2}=40.44 \\
d f=7 \\
p(c)<.0001\end{array}$ \\
\hline
\end{tabular}


In de beschermende woonvormen verbleven relatief minder bejaarde personen dan in psychiatrische ziekenhuizen. Voor de overige leeftijasgroepen was het verschil niet erg groot (tabel 42). De patienten in psychiatrische dagbehandeling daarentegen, bleken vooral geselecteerd te zijn uit de jongere leeftijasgroepen (toetsing c). zo was 56 van de dagbehandelingspatiènten jonger dan 45 jaar.

De leeftijdsgegevens van tabel 42 geven een enigszins vertekend beeld te zien. Zo is niet de leeftijd bij opname in de beschermende woonvorm of dagbehandeling vermeld, maar de leeftijd van betrokkenen op het tijdstip van onderzoek. Vooral de bewoners van beschermende woonvormen verbleven echter reeds geruime tijd in deze instellingen (tabel 43 ).

Tabed 43: Personen (1.0.p.) in beschermende woonvormen (BWV) en psychítrische dagbehandeling ( $P D B$ ) naar verbliffsduur; percentages.

\begin{tabular}{rcc}
\hline & BWV & PDB \\
\hline$<1$ jaar & 12,88 & 51,28 \\
$1-2$ jaar & 9,3 & 20,7 \\
$3-4$ jaar & 15,5 & 8,5 \\
$5-9$ jaar & 22,5 & 14,6 \\
$10-14$ jaar & 34,1 & 2,4 \\
$>14$ jaax & 5,8 & 2,4 \\
\hline
\end{tabular}

De meeste bewoners van beschermende woonvormen waxen dus bij het begir van hun verblijf aanzienlijk jonger.

Conclusie: jongexe patiënten worden door intramurale hulpverleners eerder voor vervangende zorg ingedeeld dan oudere patiènten. ook voor psychiatriache dagbehandeling en in beschermende woonvormen worden bij voorkeur de jongere lang opgenomen patiënten geplatst. 
zoals in het begin van dit hoofdstuk is geschetst bestat de mogelijkheid dat de gevonden relaties eventueel verklaard kunnen worden door de leeftija van patientem. Bij de toetsingen van de hypothesen zal dan aok gecontroleerd dienen te worden op de factor leeftijd.

In de overzichtstabel 44 is voor de hypothesen $1 t / m$ a angegeven, of de getrokken conclusies eveneens geldig zijn voor patienten jonger dan 55 jaar en patiënten van 55 jaar en ouder.

Tabel 44: Toetsing (a) voor de hypothesen 1 t/m 8 apart voor de groep patiênten van jonger dan 55 jaar en 55 jaar en ouder.

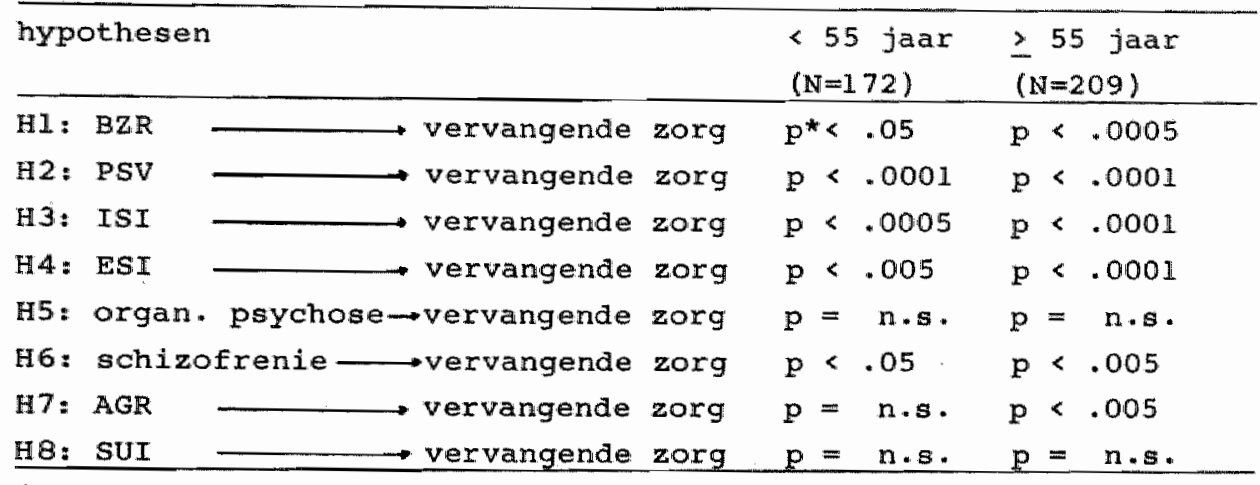

* de p-warden zijn berekend op basis van Kendall"s tau en over hetzelfde aantal categorieën als de respectievelijke tabellen.

Uit bovenstaande tabel kan worden opgemerkt, dat ook de bevindingen voor jongeren en ouderen apart overeenstemmen met de eerder vermelde resultaten yoor de totale steekproef. Een uitzondering hiexop vormen de jongere patienten in verband met agressie.

ongeacht de aard en de mate van hun vaardigheden hebben jongere patienten overigens wel een aanzienlijk grotere kans om voor vervangende zorg in aanmerking te komen dan oudere patienten. De volgende schema"s tonen dit duidelijk aan. 
Schema 10: Aandeel (f) patienten dat voor vervangende zorg in anmerking kont nat mate van basale zelfredzaamhela (BZR): pex leeftijagroep en totaal.

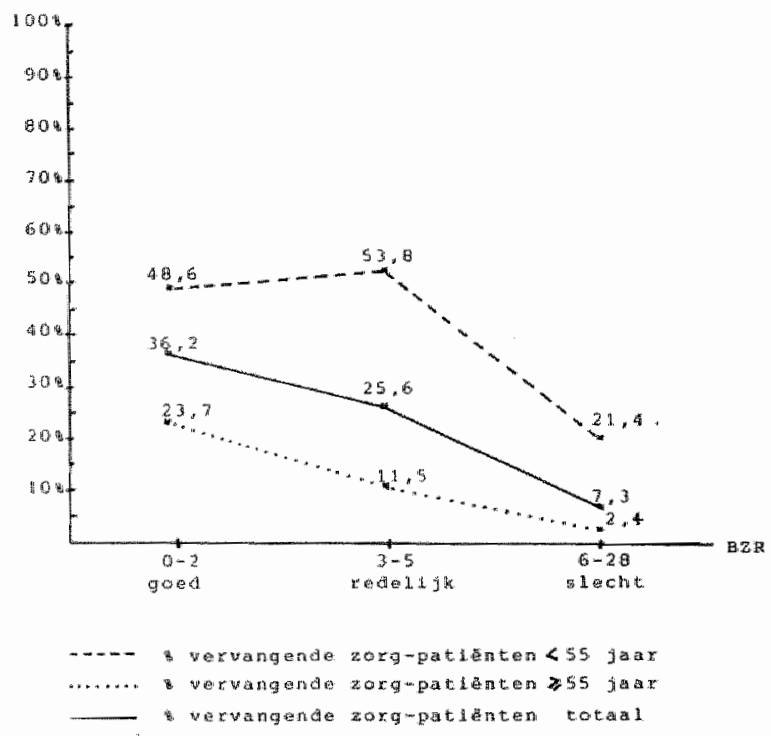

Naar aanleiding van schema $10 \mathrm{kan}$ worden opgemerkt dat ook de jongere patiënten met een redelijke BzR-score (3-5) nog voor meer dan de helft door hun hulpverleners werden ingedeeld voor vervangende zorg. Bij de oudere patiënten daalde de kans op vervangende zorg bij een geringere BzR.

Het verschil tussen jongeren en ouderen bij gelijke BZR is opvallend consistent. Zo werden bij eer BZR-score van 0-2 twee keer zoveel jongeren als ouderen ingedeeld voor vervangende zorg, bij een $\mathbb{B Z R}$-score van 3-5 vijf keer zoveel, terwiji tenslotte bij een score van 6-28 bijna tien keer zoveel jongere als oudere patienten voor vervangende zorg werden aangemerkt.

Ongeacht de mate wan basale zelfredzaamheld, waarover de pat ten beschikten, speelde dus de leeftijd van de patiënten een belangrijke rol bij het oordeel over vervangende zorg. 
De twee laatstgenoemde verhoudingscijfers werden overigens berekend op een betrekkelijk gering aantal patienten. Het merendeel wan de patiënten was goed zelfredzaam. Zo beschikte 848 van de jongere patiënten over een goede BZR, terwijl dat voor de oudere patienten nog 678 was.

Woor zowel patiënten die jongex waren dan 55 jaar als voor patiënten van 55 jaar en ouder, gold dat ook met meer beperkingen in PSV, ISI en ESI minder patiënten voor vervangende zorg werden ingedeeld (schema"s 11,12 en 13).

Een opvallend verschiljnsel in deze drie schema's is wederom dat, bij gelijke vaardigheidsscores, aanzienlijk meer jongeren dan ouderen genoemd werden als kandidaten voor vervangende zorg.

Schema 11: Aandeel patienten ( 8 ) dat voor vervangende zorg in aanmerking komt naar mate van potentieel sociale vaardigheden (PSV); per leeftijdsgroep en totaal.

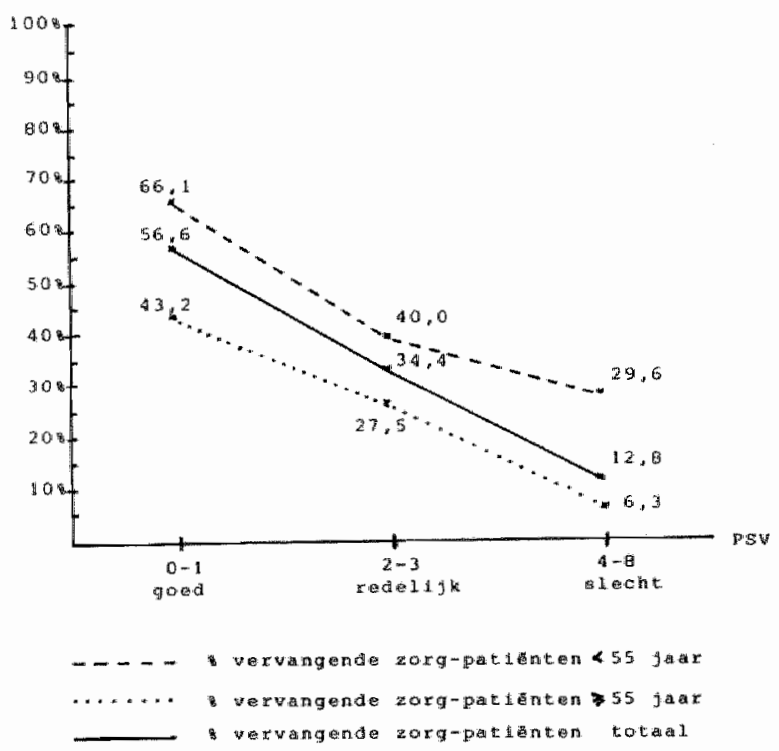


Bij gelijke potentieel sociale varaigheden kwamen jongere patienten eexdex voor vervangende zorg in aanmeking, dan oudere patienten. Tweederde van de jongere patienten met goede pSV werd door beide hulpverleners genoema voor één of andere vorm van verwangende zorg, terwijl dit aandeel met $43 \%$ aanzienlijk lager lag voor oudere patiênten met goede PSV.

Schema 12: Aandeel patiënten (18) dat voor vervangende zorg in anmerking komt naar mate van interne sociale integratie (ISI); per leeftijasgroep en total.

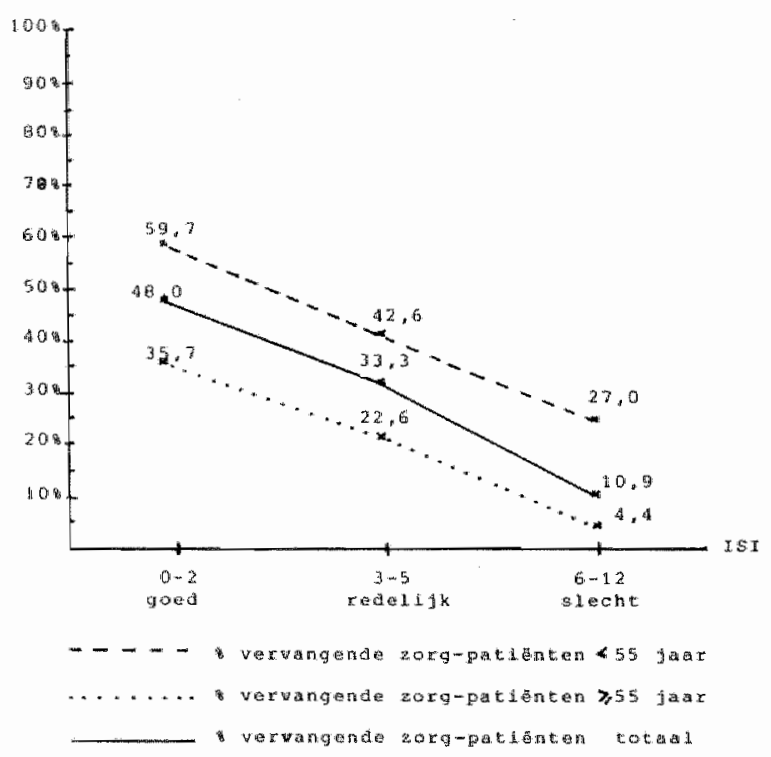

De scores voor interne sociale integratie vertonen hetzelfae beeld. Jongere patiënten met een goede, redelijke of slechte score werden systematisch meer voor vervangende zorg ingedeeld aan oudere patiénten. 
Schema 13: Aandeel patienten (8) dat voor vervangende zorg in aanmerking komt nar mate van externe sociale integratie (ESI): per leeftijdsgroep en totaal.

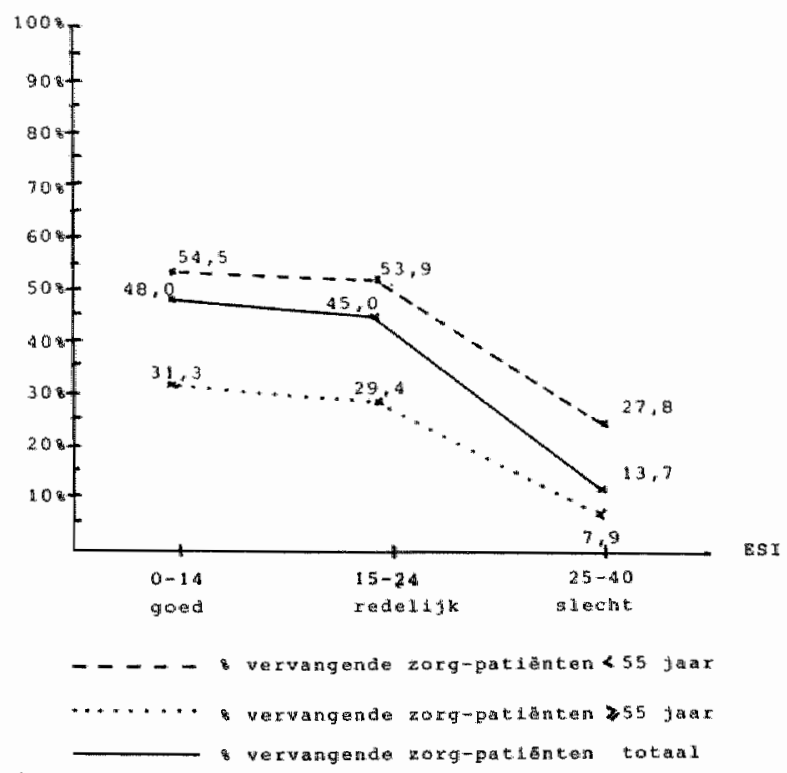

De resultaten van schema $\mathbb{1} 3$ ten aanzien van externe sociale integratie zijn consistent met de resultaten van de voorgaande drie tabelien. Ongeacht de mate wan externe sociale integratie werden patiënten die jonger dan 55 jaar waren, eerder ingedeeld voor vervangende zorg, dan oudere patiënten.

Conclusie: zowel jongere als oudere patienten komen bij geringere vaardigheden (BZR, PSV, ISI, ESI) minder in aanmerking voor vervangende zorg (hypothesen $1 \mathrm{t} / \mathrm{m} 4$ ). Bij de 1 indicatiesteling voor vervangende zorg speelt - nast de onderscheiden vaardigheden - de leeftijd van de patiënt een belangrijke rol. ook bij vergelijkbare vaardigheden kwamen oudere patiënten aanzienlijk minder in aanmerking voor vervangende zorg, volgens het oordeel van hun hulpverleners, dan patiënten die jonger dan 55 jaar waren * 
Ook ten aanzien van de sychiatrische diagnose waren de resultaten pex leettijasgrop in overeenstemming met de uitkomsten voor de totale steekproef (hypothese 5 en 6 ). Jongere en oudere patisenten met de diagnose organische psychische stoornis werden niet mirider ingedeeld voor vervangende zorg dan patiënten met een andere diagriose. De jongere en oudere schizofrene patienten kwamen daarentegen wel minder voor vervangende zorg in aanmerking (tabel 4 ).

Hebben nu jongere patiẻnten met de diagnose organische psychische stoornis of schizofrenile wederom meer kans om ingedeeld te worden voor vervangende zorg dan oudere patiënten?

Schema 14: Aandeel patiënten (8) dat voor vervangende zorg in aamerking komt naar diagnose organische psychische stoornis en overige diagnose; per leeftijasgroep en totaal

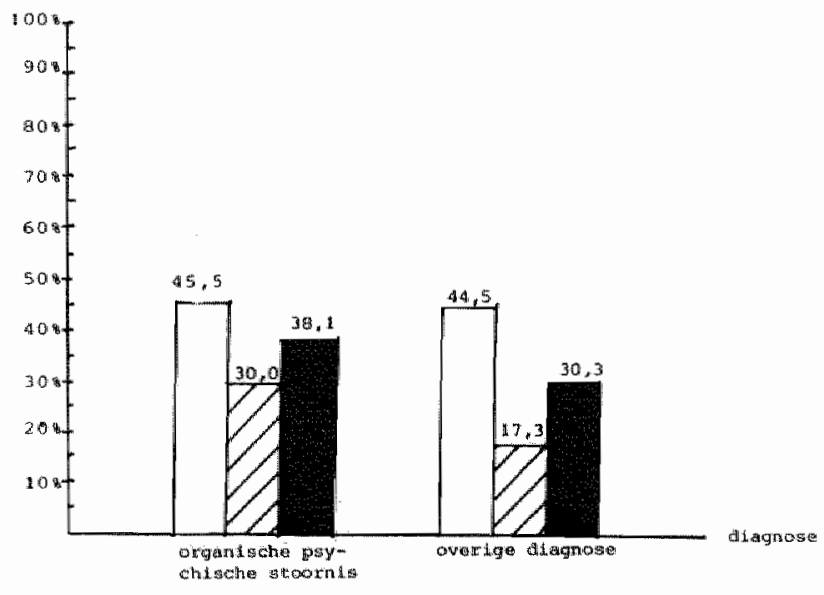

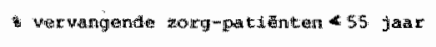

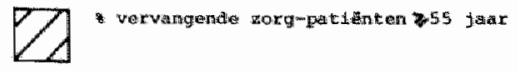

a wervargende zorg-patidntem totad. 
ook binnen de genoemde diagnostische groepen bleek leeftijd een belangrijke onathankelijke factor te zijn. Jongere patienten met een organische psychische stoornis werden nog voor 45 ingedeeld voor vervangende zorg (kolom 1 wan schema 14), terwijl dit voor slechts $30 \%$ van de oudere patiënten gold met een dergelijke diagnose.

Schema 15: Aandeel patienten (8) dat voor vervangende zorg in aanmerking komt naar diagnose schizofrenie en overige diagnose; per leeftijalsgroep en totaal.
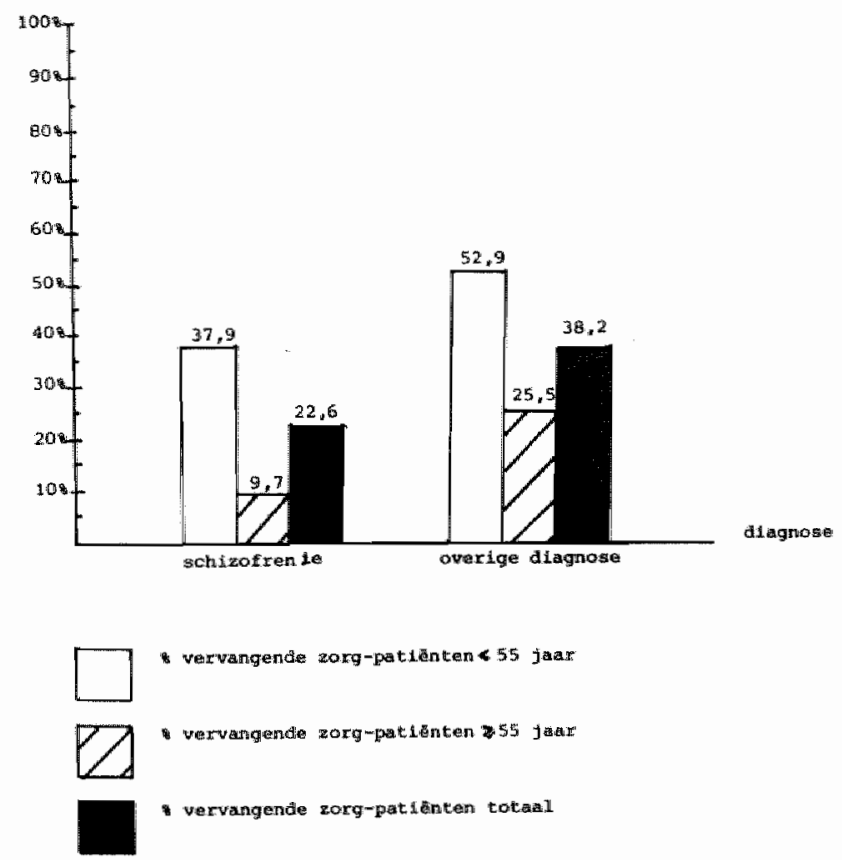

Nog opvallender $z i j n$ de verschillen tussen jongere en oudere schlzofrene patiënten. Van de schizofrene patiënten die jonger waren dan 55 jaar (kolom 1 van schema 15), kwam volgens de hulpverleners 388 in aanmerking voor vervangende zorg. Dit aandeel bleef beperkt tot 10 q voor schizofrene patiënten van 55 jaar af ouder. 
Conclusie: de resultaten ten arrien van hypothese 5 en 6 werden nogmalis bevestigd voor jongeren en ouderen apart. Patienten in de twee onderscheiden lectijasgroepen met een organische psychische stoormis kwamen niet minder in aanmerking voor vervangende zorg dan oudere patienten. De schizofrene patiënten van beide leeftijdsgroepen bleken daarentegen wel minder daarvoor ingedeeld te $z i j n$.

Opwallend is wederom de belangrijke rol die de leeftijd van de patient speelt bij de indicatiesteliing. Dok binnen de onderscheiden diagnosegroepen "schizofrenie" en "organische psychische stoornis" hadden oudere patienten aanzienlijk minder kans op een positief oordeel ten aanzien van vervangende zorg dan jongere patiënten.

Vooral voor de jongere patienten (\&55 jaar) bestaat voldoende anlelding (tabel 44) om de relatie agressie en vervangende zorg nader te analyseren (schema 16 ).

Schema 16: Aandeel patiënten (8) dat voor vervangende zorg in aamerking komt nat mate van agressiviteit (AGR); per leeftijasgroep en totaal.

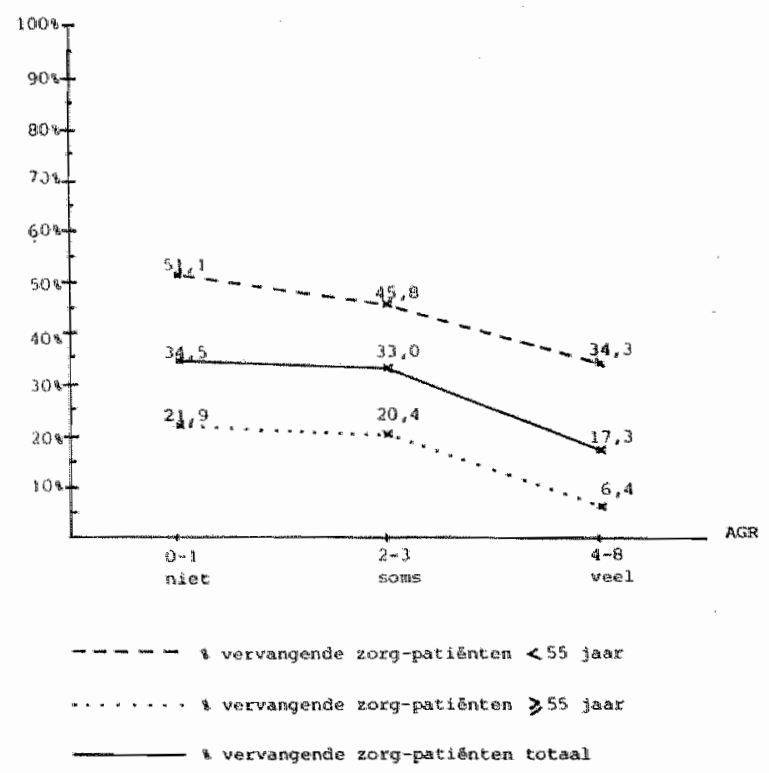


Uit schema 16 wordt duidelijk dat zowel jongere als oudere patienten pas bij een AGR-score van 4 of meer minder in anmerking komen voor vervangende zorg. Dit was in overeensteming met de resultaten voor de gehele steekproef. Voor de totale groep bleek een AGR-score van 4 een belangrijke grenswaarde te zijn. Met een hogere score daalde de kans op vervangende zorg a anzienlijk (hedst. 12.4.).

Alhoewel ook voor de jongere patiënten de kans op vervangende zorg bij meer agressie afnam, werden $z i j$ in het algemeen toch gunstiger beoordeeld dan oudere patiënten. Van de jongere patiënten die soms agressief gedrag vertoonden, kwam volgens de hulpverleners $46 \%$ in aanmerking voor vervangende zorg. De oudere patiënten $\left(55^{+}\right)$met dezelfde mate van agressie werden daarentegen slechts voor 20 \% genoemd voor vervangende zorg. De verschillen tussen jongere en oudere patiénten zijn nog groter bij patiënten die betrekkelijk veel agressie vertoonden. Zo werd éénderde (34\%) van de agressieve jongere patiënten voor vervangende zorg aangemerkt tegenover $6 \%$ van de patiënten op oudere Leeftijd.

Concluderend kan worden vastgesteld dat pas bij ernstige vormen van agressie duidelijk minder jongere en oudere patiënten voor vervangende zorg in aanmerking komen. Ongeacht de mate van agressie hebben jongere patiënten een grotere kans op een positief oordeel voor vervangende zorg dan oudere patiënten.

Suicidaal gedrag, waartoe ook het dreigen met suicide werd gerokend, kwam bij de steekproefpatienten van de psychiatrische ziekenhuizen weinig voor. Van deze patiënten had $6 \%$ een suI-score van 2 of meer. Het aantal patienten met een duidelijk suicidaliteitsrisico was te klein on nog eens apart per leeftijdsgroep te analyseren nar de mate warin zij in aanmerking komen voor vervangende zorg. Het desbetreffende schema is dan ook achterwege gelaten. 
Terugblikkend op de resultaten van dit hoofastuk is gebleken dat de leeftijd van lang opgenomen patienten een belangrijke factor is voor hulpverleners, als zij patiënten moeten beoordelen voor verwangende zorg. Ook al hebben oudere patiënten dezelfde basale zelfredzaameid, potentieel sociale vaaraigheden, interne en externe sociale integratie, en al zijn zij vergelijkbaar wat betreft agressief gedrag en psychiatrische diagnose, dan nog hebben zij steeds een geringere kans on in aanmerking te komen voor vervangende zorg dan jongere patięnten.

\subsection{Leeftijd en ae ontslagattitude van de patiënt}

Tot hier is aan de orde geweest of oudere patienten wel of niet voor vervangende zorg in aanmerking kunnen komen volgens het oordeel van de hulpverleners, gezien de vaardigheden van betrokkene (HI-H4). Tevens werd nagegaan, of zij daarvoor in aanmerking mogen komen gezien het eventuele gevaax voor zichzelf of anderen. $(\mathrm{H} 7-\mathrm{HB})$.

Hierna zal worden ingegaan op de vraag of de patienten ook zelf in aanmerking willen komen voor ontslag en huisvesting buiten de instelling. Tevens zal worden onderzocht, of jongere en oudere patiënten in deze wens en houding systematisch van elkaar verschilien.

Naar aanleiding van het ondexzoek van wing e.a. (1957) werd aangenomen dat vooral oudere lang opgenomen patiënten een negatieve houding zouden vertonen bij een tiental vragen over een mogelijk verblijif buiten de instelling. Van de jongere patienten werd darentegen een positieve houding verwacht.

H10: Naarmate lang opgenomen patienten ouder zijn, hebben zij minder de wens om het psychiatrisch ziekenhuis te verlaten. 
Tabel 45: Lang opgenomen patiënten in psychiatrische ziekenhuizen naar leeftijd en houding ten aanzien van ontslag (H.O.); percentages.

\begin{tabular}{|c|c|c|c|c|c|c|c|c|}
\hline leeftija & $\geq 75$ & $74-65$ & $64-55$ & $54-45$ & $44-35$ & $34-25$ & $<25$ & totaal \\
\hline negatief & $40 \%$ & $36 \%$ & $30 \%$ & 18 웅 & 168 & 145 & -- & 268 \\
\hline ambivalent & 42 & 35 & 39 & 33 & 42 & 27 & 17 & 37 \\
\hline positief & 18 & 29 & 31 & 49 & 42 & 59 & 83 & 37 \\
\hline totaal 8 & 1008 & 1008 & 1008 & 1008 & 1008 & 1008 & 1008 & 1008 \\
\hline totaal abs. & 38 & 52 & 67 & 51 & 5.5 & 22 & 6 & 291 \\
\hline
\end{tabular}

De resultaten van bovenstaande tabel ondersteunen de hypothese. Met de leeftijd nam ook het aandeel patiënten toe dat negatief of ambivalent tegenover ontslag stond. Tot een leeftijd van 55 jaar gaf nog ongeveer de helft van de patiënten te kennen ontslagen te wilen worden. Vanaf deze leeftijd daalde geleidelijk het aandeell. Uiteindelijk wilde van de patienten die 75 jaar of ouder waren, slechts éénvijfde (18\%) ontslagen worden.

Conclusie: de hypothese dat oudere patiënten minder de wens hebben om ontslagen te worden dan jongere patiënten, werd bevestigd. Vooral de patienten die 55 jaar of ouder waren, hadden een ambivalente of negatieve houding ten aanzien van ontslag. De patiënten in deze leeftijdsgroep ervaren het perspectief orm buitem de instelling te leven, veelal als weinig wenselijk, - en misschien zelfs als een bedreiging voor bestaande rechten, zekerheden, beschutting en het vaste leefpatroon binnen het psychiatrische ziekenhuis.

\subsection{Juridische situatie}

Bij de start van het onderzoek werd aangenomen dat de civiel- of strafrechterlijk opgenomen patiënten minder voor vervangende zorg zouden worden ingedeela dan vrijwillig opgenomen patienten. Deze veronderstelling resulteerde in de volgende hypothese: 
HLL: Als lang opgenomen patienter via een civiel-of stratrechterlijke procedure in het psychiatrisch ziekenhuis verblijven. komen zij minder voor vervangende zorg in aanmerking dan patienten die daar - juridisch gezien - vrijwiliig verbiljver.

Tabel 46: Lang opgenomen patiènten in psychiatrische ziekenhuizen naar juridische situatie en mogelijkheden voor vervangende zorgi absolut en percentages.

\begin{tabular}{|c|c|c|c|}
\hline juridische situatie & vrijwillig & onvrijwil11g & totaal \\
\hline $\begin{array}{l}\text { vervangende } \\
\text { zorg groep }\end{array}$ & $(30 \%)$ & $(408)$ & $(308)$ \\
\hline overige patiënten & 256 & 9 & 265 \\
\hline totaal & $366(100 \%)$ & $15(1008)$ & $381(1008)$ \\
\hline
\end{tabular}

De resultaten ondersteunen deze hypothese niet, hoewel we met deze conclusie voorzichtig moeten zijn gezien het geringe aratal onvrijwillig opgenomen patiënten. Van de 13 patiënten die onder een rechterlijke machtiging (R.M.) in de instelling verbleven en 2 patiënten die op uitspraak van de strafrechter waren opgemomen, in het totaal dus 15 onvrijwillig opgenomen patiënter, bleken 6 patiënten ofwel $40 \%$, voor vervangende zorg in aanmerking te komen. De hulpverleners moemden in dit verband psychiatrische agbehandeling en bescherma kleinschalig wonen op en buiten het terrein van het psychiatrisch ziekenhuis.

Tabel 47: Pexsonem (1.0.p.) im psychiatrische zilekenhuizen (APz). beschermende woonvormen (BWV) en psychlatrische dagbehandeling (PDB) naar juridische situatie; percentages.

\begin{tabular}{lccc}
\hline $\begin{array}{l}\text { Juridische } \\
\text { situatie }\end{array}$ & $\begin{array}{c}\text { APZ } \\
(N=381)\end{array}$ & $\begin{array}{c}\text { BWV } \\
(\mathrm{N}=179)\end{array}$ & $\begin{array}{c}\text { PDB } \\
(\mathrm{N}=86)\end{array}$ \\
\hline vrijwillig & 96,18 & 100,08 & 96,58 \\
onvrijwillig & 3,9 & - & 3,5 \\
\hline total & 100,08 & 100,08 & 100,08 \\
\hline
\end{tabular}


In beschermende woonvormen mogen wettelijk gezien geen patienten met een zgn. rechterlijke machtiging of inbewaringsteling verblijven, omat het geen aangewezen afdelingen zijn in de zin van de Krankzinnilgenwet. Het is dan ook niet verbazingwekkend at in deze instellingen alle bewoners vrijwillig verblijven.

Hetzelfde werd overigens verwacht ten aanzien van de patienten in psychiatrische dagbehandeling. Gemeend werd dat ook in deze voorzieningen alle personen vrijwillig zouden verblijven. Dat bleek echter niet zo te zijn. Drie patiënten, ofwel 3,5q van de steekproef, verbleven met een rechterlijke machtiging (R.M.) in dagbehandeling. Een mogelijke verklaring voor dit verschijnsel is dat dagbehandeling voor enkele R.M.-patiënten wordt gebruikt als een gefaseerde stap van rehabilitatie door middel van proefverlof. De relatie met de kliniek blijft dan bestaan en tevens de juridische verantwoordelijkheid, terwijl er gelijkertijd voldoende mogelijkheden zijn om volledig ontslag uit de kliniek voor te berelien.

Conclusie: voor hypothese 11 werd weinig ondersteuning gevonden. ook voor patienten die met een rechterlijke machtiging in het psychiatrisch ziekenhuis verbleven, werd in dezelfde mate als voor andere lang opgenomen patiënten naar alternatieve opvangmogelijkheden gezocht, bijvoorbeeld in de vorm van dagbehandeling of beschermd kleinschalig wonen op of buiten het terrein, mar dan wel onder de verantwoordelijkheid en de rechtspersoon van het psychiatrisch ziekemhuis.

\subsection{Verblijfsduur}

Een ononderbroken verblijf van 20 jaar of langer in een psychiatrisch ziekenhuis is ook in de huidige tijd geen uitzondering. Bijna één op de vier van de lang opgenomen patiënten wan de steekproef had een dergelijk lange verblijfsduur. En nog eens twee op de vier patienten verbleven zes tot twintíg jaar continu in de $\mathbb{1}$ insteling.

In het onderzoek werd aangenomen dat dergelijke verschillen in verblijfsduur een ral zouden spelen bij het oordeel van de hulpverleners over mogelijkheden voor vervangende zorg. 
H12: Naarmate patienten langer in het psychiatrisch ziekenhuis verblijven, komen zij minder in aanmerking voor vervangende zorg.

Tabel 48: Lang opgenomen patienten in psychiatrische ziekenhuizen naar verblijfsaur en mogelijkheden voor vervangende zorg; absoluut en pexcentages.

\begin{tabular}{|c|c|c|c|c|c|c|c|}
\hline verblijfsauur & $<5$ & jaar & $6-20$ & jaar & $>20$ & jaar & totaal \\
\hline \multicolumn{8}{|l|}{ vervarugende } \\
\hline zorg groep & 49 & $(458)$ & 59 & $(328)$ & 8 & $(98)$ & $(30 \%)$ \\
\hline overige patienten & 59 & & 123 & & 83 & & 265 \\
\hline totaal & 208 & $(1008)$ & 182 & $(1008)$ & 91 & $(1008)$ & $381(1008)$ \\
\hline
\end{tabular}

De resultaten van tabel 48 bevestigen deze hypothese. Van de patienten die korter dan 5 jaar in de insteliling verbleven, werd 45 door de hulpverleners voor één of andere vorm van vervangende zorg geindiceerd. Dit aandeel nam geleidelijk af tot 9 s van de patiënten die langer dan twintig jaar waren opgenomen. De daarop aansluitende vraag $i s$, of in de steekproef van dagbehandeling en beschermende woonvormen aanzienlijk minder personen voorkomen met een lange klinische verblijfsduur dan men zou verwachten op basis van de verblijfsduur van de patiënten in psychiatrische ziekenhuizen (toetsing $b$ en $c$ ). 
Tabel 49: Personen (1.0.p.) in psychiatrische ziekenhuizen (APZ), beschermende woonvormen (BWV) en psychiatrische dagbehandeling ( $P D B$ ) naar klinische verblijfsduurgroep: percentages.

\begin{tabular}{|c|c|c|c|}
\hline $\begin{array}{l}\text { klinische ver- } \\
\text { blijfsduurgroep }\end{array}$ & $\begin{array}{l}\mathrm{APZ} \\
(\mathrm{N}=381)\end{array}$ & $\begin{array}{l}\text { BWV } \\
(N=179)\end{array}$ & $\begin{array}{l}\mathrm{PDB} \\
(\mathrm{N}=86)\end{array}$ \\
\hline $\mathrm{z} \cdot 1 \cdot \mathrm{o} \cdot \mathrm{p}$ & 65,38 & 52,58 & 27,98 \\
\hline $1.0 \cdot \mathrm{p} \cdot \mathrm{c}$ & 23,8 & 25.7 & 34,9 \\
\hline $1 \cdot 0 \cdot p \cdot-d c$ & 11,0 & 21,8 & 37,2 \\
\hline \multirow[t]{2}{*}{ totaal } & 100,08 & 100,08 & 100,08 \\
\hline & & $\begin{array}{l}x^{2}=13.35 \\
d f=2 \\
p(b)<.005\end{array}$ & $\begin{array}{l}x^{2}=50,81 \\
d f=2 \\
p(c)<.0001\end{array}$ \\
\hline
\end{tabular}

Deze vraag moet bevestigend woraen beantwoord gezien de resultaten van tabel 49. Zowel in beschermende woonvormen maar vooral in psychiatrische dagbehandeling verbleven aanzienlijk minder personen die daarvoor langer dan 5 jaar continu waren opgenomen geweest in een psychiatrisch ziekenhuis (z.1.0.p.). Conclusie: de resultaten van de drie toetsingen zijn onderling consistent en ondersteunem de hypothese dat met de dur van de klinische opname de kans op vervangende zorg afneemt.

Het is voorstelbaar dat de duux van het verblijf van een patiënt in het psychiatrisch ziekenhuis niet alleen van invloed is op het oordeel van hulpverleners, max tevens medebepalend is voor de ontslaghouding van de patiënt zelf. In dit verband werd van de vollgende veronderstelling uitgegaan.

H13: Naarmate patiënten langer in een psychiatrisch ziekenhuis verblijven, hebben zij minder de wens om ontslagen te worder. 
Tabe1 50: Lang opgenomen patienten in psychiatrische ziekenhulzen naar verblijfsduur bij de latste oprame en houding ten aanzien van ontslag (H.O.); percentages.

\begin{tabular}{|c|c|c|c|c|c|c|c|}
\hline $\begin{array}{l}\text { verblijfs- } \\
\text { duur }\end{array}$ & $>30 \mathrm{j}$. & $\begin{array}{l}30-21 \\
\text { jaar }\end{array}$ & $\begin{array}{l}20-11 \\
\text { jaar }\end{array}$ & $\begin{array}{l}10-6 \\
\text { jaar }\end{array}$ & $\begin{array}{l}5-3 \\
j a a r\end{array}$ & $<2 \mathrm{j}$. & total 1 \\
\hline positief & 238 & 308 & 28 & 488 & 42 & $51 \%$ & 38 욤 \\
\hline ambi valent & 33 & 23 & 41 & 36 & 39 & 43 & 36 \\
\hline negatief & 44 & 47 & 31 & 16 & 19 & 6 & 26 \\
\hline total 1 & $100 \%$ & $100 \%$ & 1008 & $100 \%$ & $100 \%$ & $100 \%$ & 1008 \\
\hline totaal abs & 43 & 30 & 51 & 61. & 67 & 35 & 287 \\
\hline
\end{tabular}

In de laatste kolom van tabel 50 is te lezen dat 26 van de lang opgenomen patiënten niet meer wensen van verblijfsituatie te veranderen. Eéndexde (368) van de patienten twijfelde, terwijl een bijna evengroot aandeel $(388)$ de voorkeur gaf aan een verbliff buiten het psychiatrisch ziekenhuis.

Tussen de opnameduur van patiënten en de houding ten aanzien van ontslag bestond een duidelijk verband. Met de verblijfsduur nam ook het aantal patiënten toe dat niet met ontslag wilde gaan. aok voor de patiënten met een positieve houding ten aanzien van ontslag was een dergelijk patroon herkenbaar, alhoewel minder consistent. In de houdingsfactor lijkt een caesuur te liggen bij een verblijfsduur van ongeveer 10 jaar. Van de patiënten die larger aan 10 jaar in de instelling verbleven had ongeveer én kwart (27\%) de wers met ontslag te gaan, terwijl dit aandeel, met 468, aanzienlijk hoger lag voor patiënten die korter dan lo jaar waten opgenomen. 
Schema 17: Lang opgenomen patiënten $(\mathrm{n}=287)$ met een positieve respectievelijk negatieve houding ten arnzien van ontsilag naar opnameduur; percentages.

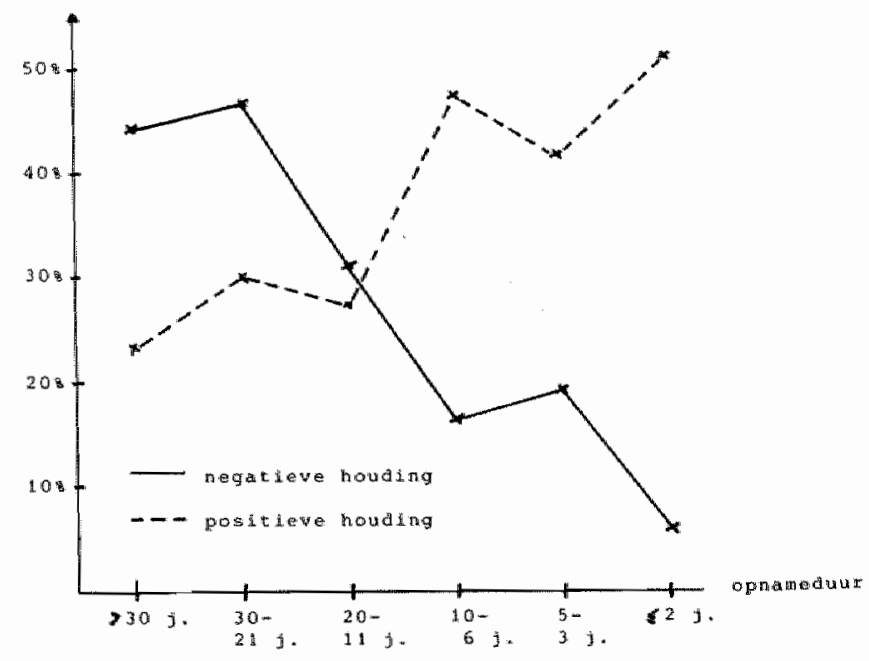

In bovenstaand schema zijn de bevindingen van tabel 50 nog eens grafisch gepresenteerd.

Conclusie: de hypothese dat patiënten met een zeer lange opnameduur minder geneiga zijn om met ontslag te gaan dan patiẻnten met een relatief kortere verblijfsduur, wordt door de resultaten van dit onderzoek ondersteund. Tot en met een verblijfsdur van 10 jaar had nog bijna de helft (468) van de patiënten de wens om ontslagen te worden. Bij een langere verblijfsduur gaat de negatieve houding ten aanzien van ontslag overheersen.

Hoe consistent is deze hypothese nu, als zij ook voor subgroepen van de steekproef wordt getoetst? Iis de hypothese ook geldig voor bijvoorbeeld jongere en oudere patiënten, manmen en vrouwen, gehuwde en alleenstaande patienten? De hypothese is naar aanleiding van deze vraag opnieuw geêxploreerd voor 26 subgroepen ten aanzien van een 13-tal variabelen, 
te weten: geslacht, leefija, burgerlijke staat, juridische situatie, psychiatrische diagnose, lichamelijke ziekte/handicap. volledigheid van thuismilieu, agressiviteit, suicidaal gedrag. basale zelfredzamheld, potentieel sociale vaardigheden, interne en externe sociale integratie (tabellen 51 en 52 ).

Tabel 5.: De relatie tussen verblijfsduur en houding tegenover ontslag, apart voor mannen en vrouwen, jongeren en ouderen, schizofrene en niet-schizofrene patiẻnten, en patidinten met een goede of minder goede BZR, PSV, ISI en ESI.

variabele

geslacht

man

leeftija

$$
\begin{aligned}
& <55 \text { jaar } \\
& \geq 55 \text { Jaar }
\end{aligned}
$$

diagnose

$$
\begin{aligned}
& \text { schizofrenie } \\
& \text { andere dilagnose }
\end{aligned}
$$

BZR

$$
\begin{array}{ll}
0-2 \text { (goed) } & .269 \\
3-28 \text { (minder goed) } & .231
\end{array}
$$

PSV

$$
\begin{array}{ll}
0-1 \text { (goed) } & .218 \\
2-8 \text { (minder goed) } & .255
\end{array}
$$

.279

.196

.183

.160

.291

.199

ISI

0- 2 (goed)

3-12 (mindex goed) ESI

.289

.222
$S$

.065

$\ll .0005$

.075

$<.005$

130

N

150

$.074<.05$

140

$.070<.0005$

147

.068

$<.005$

$.054<.0005$

228

.119

$<.05$

59

$.092<.01$

94

.062

« 005

193

.079

$\times .0005$

100

.063

$<.0005$

187

.131

n.s.

48

.054

$<.0005$

239 
Tabel 52: De relatie tussen verblijfsduur en houding tegenover ontslag, apart voor gehuwde en niet gehuwde patiënten, lichamelijk gehandicapten en niet lichamelijk gehandicapten, vrijwillig en onvrijwillig opgenomen patienten. patiënten met volledig en onvolledig thuismilieu, en patienten met of zonder agressief of suicidal gedrag.

\begin{tabular}{|c|c|c|c|c|}
\hline variabele & tau & s.e. & P & $N$ \\
\hline \multicolumn{5}{|l|}{ burgerlijke staat } \\
\hline gehuwd & .308 & .145 & $<.05$ & 29 \\
\hline alleenstaand & .239 & .051 & $<.0005$ & 258 \\
\hline \multicolumn{5}{|c|}{ lichamelijke ziekte/handicap } \\
\hline$j a$ & .132 & .099 & $\mathbf{n} \cdot \mathbf{s}$ & 68 \\
\hline nee & .280 & .055 & $\therefore 0005$ & 219 \\
\hline \multicolumn{5}{|c|}{ juridische situatie } \\
\hline vrijwillig & .224 & .050 & $<.0005$ & 275 \\
\hline onvrijwilig & .611 & .219 & $<.05$ & 12 \\
\hline \multicolumn{5}{|l|}{ thuismilleu } \\
\hline rolledig & -.015 & .112 & $\mathbf{n} \cdot \mathbf{s}$ & 88 \\
\hline onvolledig & .293 & .061 & $<.0001$ & 199 \\
\hline agressiviteit & & & . & \\
\hline geen $(0-1)$ & .303 & .064 & $<.0005$ & 166 \\
\hline meer $(2-8)$ & .156 & .075 & $<.05$ & 121 \\
\hline \multicolumn{5}{|l|}{ suricidaliteit } \\
\hline geen $(0-1)$ & .251 & .051 & $<.0005$ & 265 \\
\hline meer $(2-6)$ & .039 & .175 & n.s. & 22 \\
\hline
\end{tabular}

Voor 23 van de 26 bestudeerde subgroepen bleek een verband te bestaan tussen de verblijfsduur van patienter en hum houding tegenover een eventueel ontslag. Alleen voor een viertal subgroepen was minder duidelijk of de strekking van de hypothese ook voor hun van toepassing was. Het ging daarbij om patienten met een goede externe sociale integratie, patiënten die lichamelijk ziek of gehandicapt waren, patiènten met suicidaal gedrag en patiënten met een betrekkelijk volledig thuimilieu. 
Conclusie: hypothese 13 bleek ook geldig te zijn voor meer specifleke groepen van patienten. Alleen bij vier van de 26 in ait verband bestudeerde groepen ging een lange verblijfsdur van patienten in mindere mate gepaard met een negatieve houding ten aanzien van ontslag.

Een volgende vrag is, hoe de lang opgenomen patienten hun verblijf op de afdeling en in de instelling ervaren. Is het zo dat patiénten die zeer lang in het psychiatrisch ziekenhuis verblilven en war de tijallijke asylfunctie is overgegaan in langdurlige huidvesting, steun en begeleiaing, de leefsituatie binnen het instituut positiever ervaren dan patienten die minder lang zijn opgenomen?

In het onderzoek werd verondersteld dat de patiënten die nog niet al te lang geleden werden opgenomen, een minder positieve houding zouden innemen tegenover de leefsituatie binnen het instituat dan patiënten die dar reeds zeer lang verblijven. Deze aanname was gebaseerd op common-sense-redeneringen en niet op een ge expliciteerd en te toetsen theoretisch model. Zo werd aangenomen dat:

- patiẻnten die zeer lang zijn opgenomen, misschien ook meer kwetsbaar zijn en daardoor de huisvesting, de begeleiding en de formele/informele contacten met patiēnten en hulpverleners gunstiger ervaren:

- zeer lang opgenomen patiënten misschien beter gewend zijn aan de huisvesting en de huisregels van het instituat, dan patienten die minder lang zijn opgenomen:

- zeer lang opgenomen patiënten misschien minder geloven in de hatbaarheid of wenselijkheid van een verblijf buiten het instltuut en darom het verbliff in de huldige insteling extra warderen: en dat

- zeer lang opgenomen patiënten misschien meer erin zijn geslaagd - net veel moelte - om een nieuwe kennissenkring op te bouwen bestaande uit medebewoners en personeelsleden, dan patienten die nog niet zo lang in de inrichting verblijven. 
H14: Naarmate patiënten langer in een psychiatrisch ziekenhuis verblijven, is hun houding positiever ten opzichte van de afdeling en instelling.

Tabel 53: Lang opgenomen patienten in psychiatrische ziekenhuizen naar verblijfsduur en houding ten anzien van afdeling/ instelling (H.A.); percentages.

\begin{tabular}{|c|c|c|c|c|c|c|c|}
\hline $\begin{array}{l}\text { verblijfs- } \\
\text { dunr }\end{array}$ & $>30 \mathrm{j}$ & $\begin{array}{l}30-21 \\
j a a r\end{array}$ & $\begin{array}{l}20-11 \\
\text { jaar }\end{array}$ & $\begin{array}{l}10-6 \\
\text { jaar }\end{array}$ & $\begin{array}{l}5-3 \\
j a a r\end{array}$ & $\leq 2 j$. & totaal \\
\hline positief & 518 & 638 & 558 & 468 & 238 & 298 & 428 \\
\hline ambivalent & 40 & 27 & 33 & 47 & $6 \mathbb{1}$ & 63 & 47 \\
\hline negatief & 9 & 10 & 12 & 7 & 16 & 8 & 11 \\
\hline totaal & 1008 & 1008 & 1008 & 1008 & 1008 & 1008 & $100 \%$ \\
\hline totaal abs. & 43 & 30 & 51 & 61 & 67 & 35 & 287 \\
\hline
\end{tabular}

Tussen de verblijfsduur van patiënten en de houding ten opzichte van afdeling en instelling bleek een verband in de veronderstelde richting te bestaan (tabel 53). Een langere verbliffsduur ging gepaard met een positieve instelling van patiënten tegenover de eigen afdeling en instelling. Vanaf een verblijfsduur van 6 jaar was er sprake van een hoog percentage personen met een positieve houding. Men zou kunnen stellen dat de ambivalente houding ten aanzien van afdeling en instelling met de duur van het verblijf steeds meer wordt vervangen door een positieve, aanwardende attitude.

Het omgekeerde van hypothese 14 was niet geldig. Een korte verblijfsdur ging niet gepaard met een meer negatieve houding ten opzichte van afdeling en instelling. Het aandeel patienten met een uitgesproken negatieve houding bleef over de verschillende verblijfsduurgroepen betrekkelijk constant. Kort en lang opgenomen patiënten verschiliden in die zin van elkaar dat patiënten tot en met een verblijfsduur van 10 jaar ambivalent waren in hun houding terwijl de patiënten met een langere verblijfaduur vooral 
een positieve houding inramen tegenover hun afdeling en instelling.

Conclusie: bovengenomde resultaten ondersteunen de hypothese dat met toenemende verblijfsduur de houding van de patient ten opzjohte van de afdeling en instelling positiever wordt.

Ten a anzien van deze conclusie kan wederom de vraag worden gesteld, of het verband ook aantoonbaar is voor verschillende subgroepen van de steekproef. Voor de beantwoording van deze vraag werd gebruik gemakkt van dezelfde variabelen en groepen als bij tabe 151 en 52 .

ook voor de subgroepen werd dus verwacht: een hoog percentage patiënten met een positieve H.A.-score bij een zeer lange verblijfsduur, en een laag percentage voor patiënten met een betrekkelijk korte verblijfsduur. De schema"s zouden dus in principe allemal een dalende lijn te $z$ ilen moeten geven.

Schema 18: Aandeel patiënten (8) met een positieve houding ten

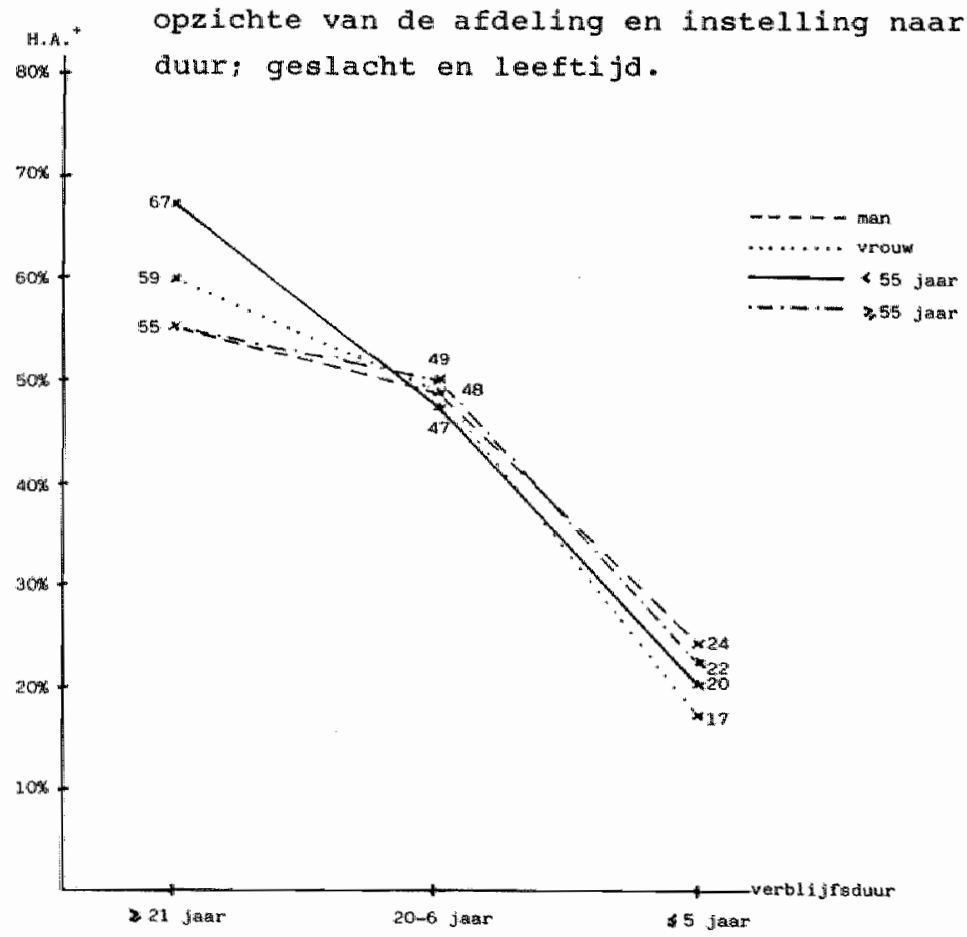


Bif schema 18 kon dezelfde relatle worden geconstateerd voor mannen en vrouwen, en tevens voor jongere en oudere patienten: met de duur van de opname was de houding ten opzichte van de afaling en instelling positiever.

In de scoreverdeling vertoonden mannen en vrouwen eenzelfde patroon. Het aandeel mannen en het aandeel vrouwen met een positieve attitude verschilde per verblijfsduurgroep nauwelijks. Eenzelfde trend kon ook worden opgemerkt voor patiënten die jonger dan 55 jaar waren en voor patienten van 55 jaar of ouder. Evenveel jongere en oudere patiënten met een opnameduur van korter dan 5 jaar of een verblijfsduur van 6 tot 20 jaar namen een positleve houding in ten opzichte van afdeling en instelling. Opmerkelijk was wel dat met een nog langere opnameduur, namelijk 20 jaar of langer, tweederde $(678)$ van de jongere patienten positief stond ten opzichte van de afdeling en instelling, terwijl dit alleen gold voor $55 \%$ van de oudere patiënten.

Schema 19: Aandeel patiënten (\%) met een positieve houding ten opzichte van de afdeling en instelling naar verblijfs-

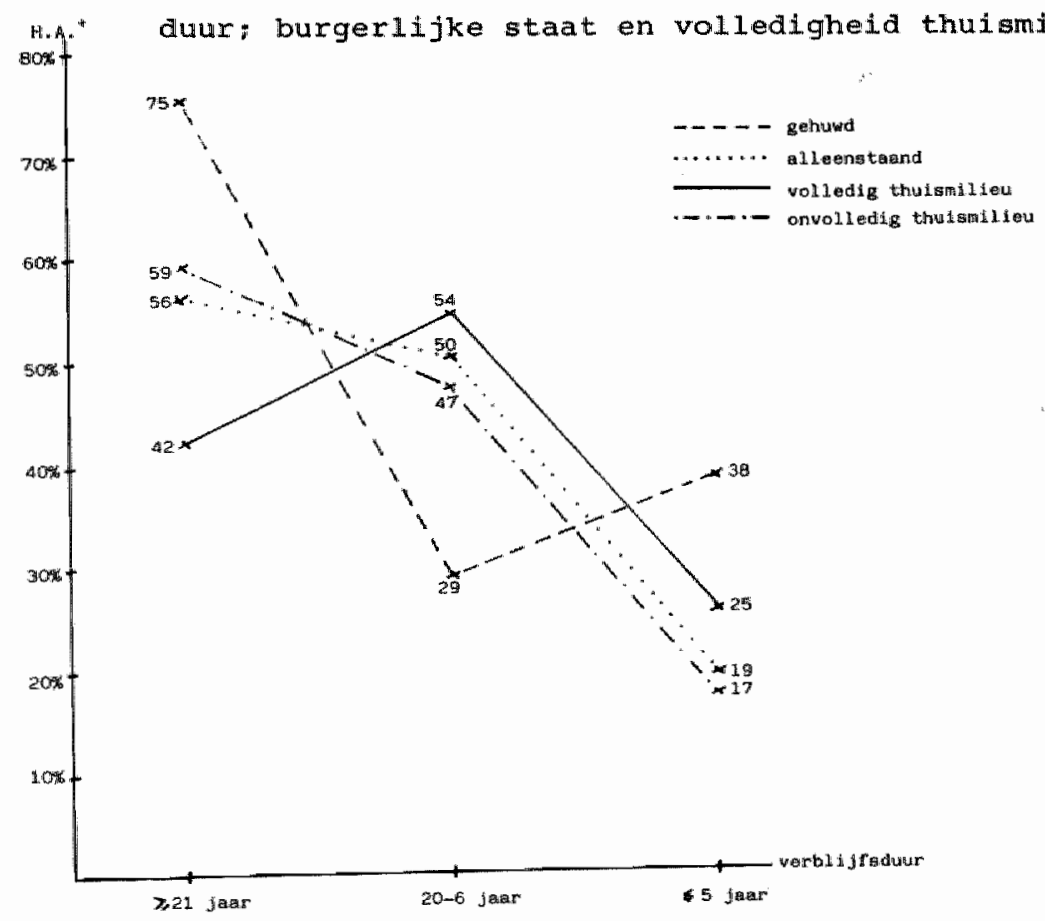


Bij de gehuwde patiënten en patiënten met een betrekkelijk volledig thuimilieu bestond in verband met hypothese 13 een inconsistent patroon (schema 19). Zo was het aandeel gehuwde patiènten met een positieve houding in de verbliffsurgroep $\leq 5$ jaar met 38 groter dan in de verbliffsduurgroep 6-20 jaar (298). Bij de groep patienten met een betrekkelijjk volledig thuismilieu bleken. de pationten met de langste verblijfoduren ( 21 jaar) minder positief te staan ten opzichte van afdeling en insteliing (428) dan de vergelijkbare groep patiënten met een verblijfsduur van $6-20$ jaar $(548)$.

Schema 20: Aandeel patiënten ( met een positieve houding ten opzichte van de afdeling en instelling naar verblijfsduur; psychiatrische diagnose en lichamelijke ziekte/handicap.

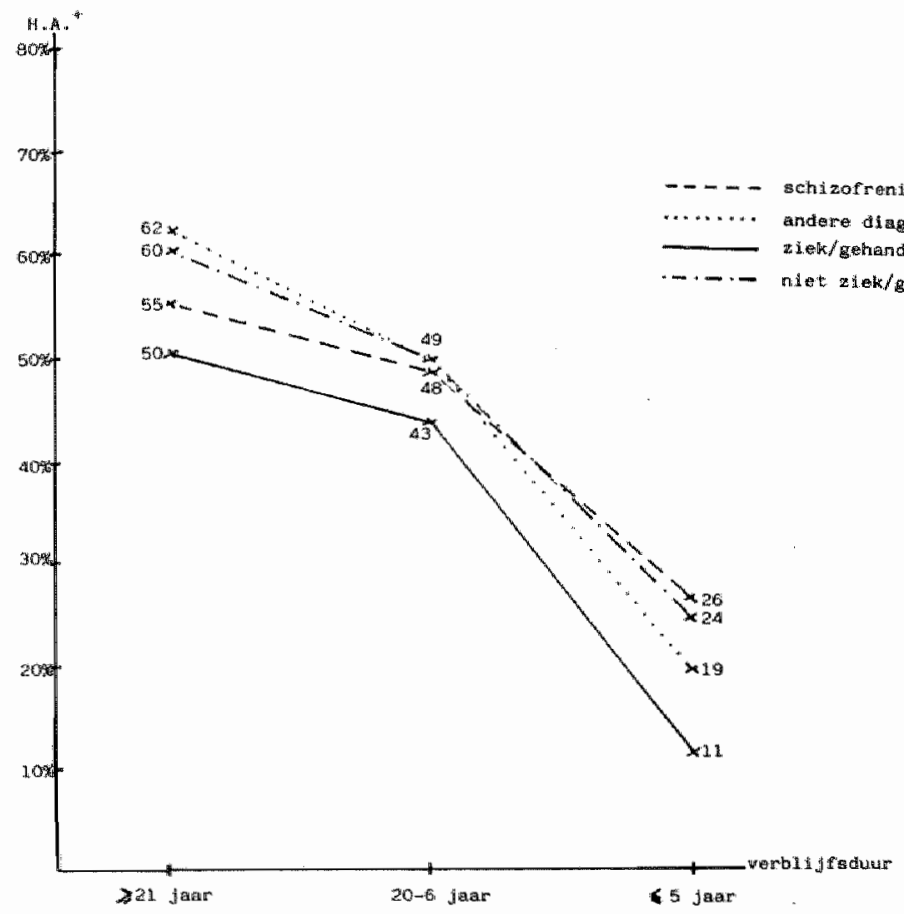


Het aandeel schizofrene patiënten dat een positieve houding innam ten opzichte van afdeling en instelling (schema 20), verschilde niet veel per verblijfsduurgroep van patiënten met een andere psychlatrische diagnose. Wel werd in de groep patienten warbij een lichamelijke ziekte of handicap gepaard ging met functiebeperkingen bij zien, horen, spreken of lopen, minder vaak een positieve houding aangetroffen dan in de groep patiënten zonder dergelijke lichamelijke beperkingen. Deze bevinding gold voor alle arie onderscheiden verblijfsduurgroepen.

Alle vier subgroepen van schema 20 vertonen overigens hetzelfae patroon als de totale groep: hoe langer de opnameduur is, hoe groter het aandeel patiënten met een positieve houding ten aanzien van afdeling en instelling.

Scherna 21: Aandeel patiënten (\%) met een positieve houding ten opzichte van de afdeling en insteling nar verblijfs-

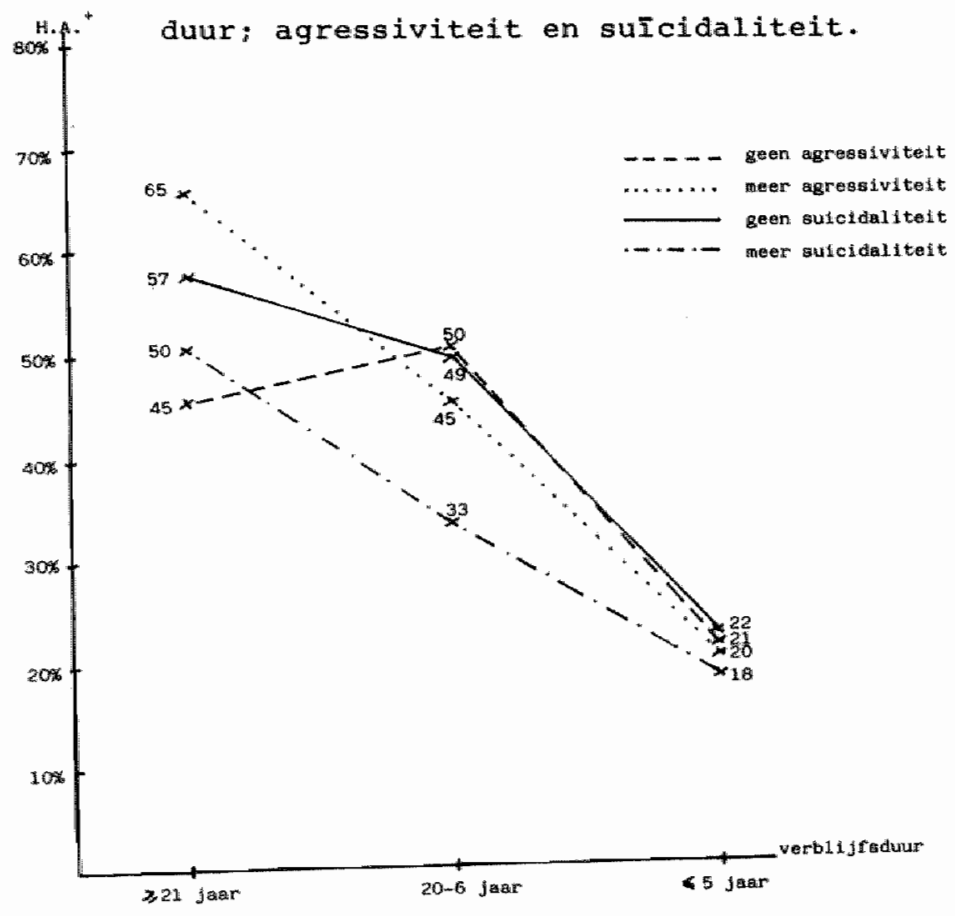


De resultaten voor patiënten met enige vorm van agressief gedrag. en patienten met en zondex suicidaal gedrag waren conform de bevindingen voor de totale groep. Ook voor deze drie subgroepen was sprake van een meer positieve afdelings- en instelingsatttude, naamate de opnamedur langer was. Wel was het aandeel van de meer suldidale patienten dat een positieve houding had, met 336 betrekkelijk gering voor de verblijfsduurgroep 6-20 jaar. Opvallend was ook dat van de patienten die langer dan 20 jaar waren opgenomen en meer agressief gedrag vertoonden dan andere patienten, toch $65 \%$ tijdens het interview te kemmen gaf een positieve houding te hebben ten opzichte van de afdeling en instelIing.

Schema 22: Aandeel patienten (z) met een positieve houding ten opzichte van de afdeling en instelling naar verblijfsduur; basale zelfredzaamheid (BZR) en potentieel sociale vaardigheden (FSV).

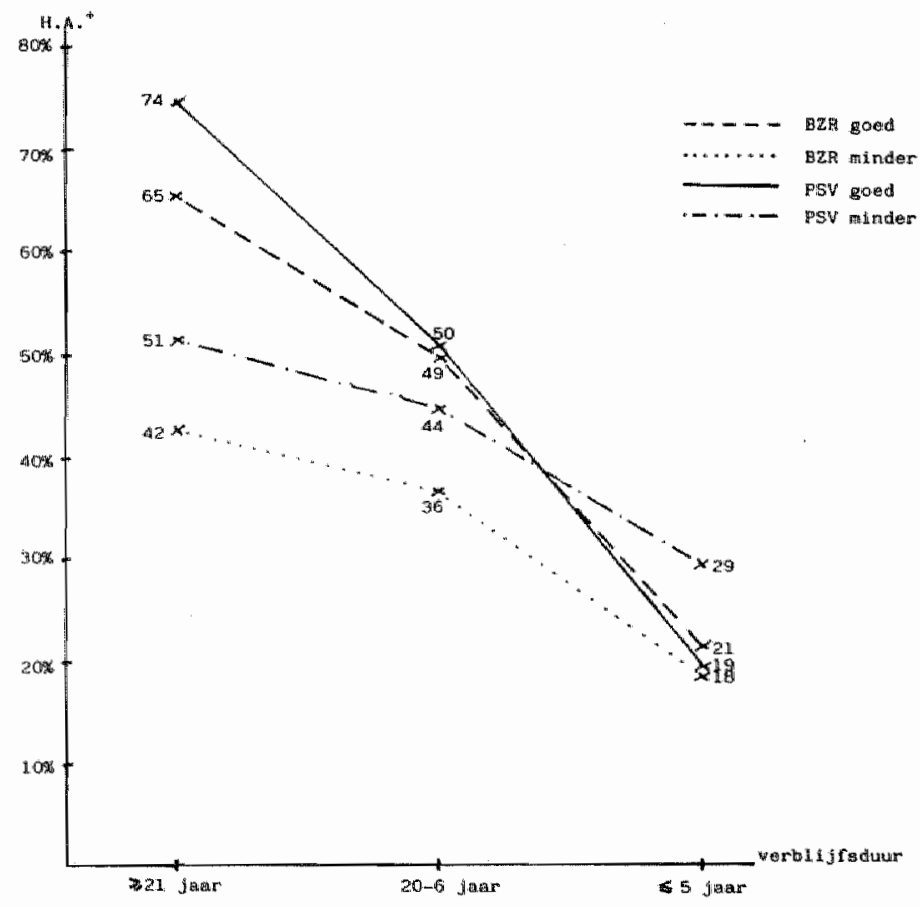


Zowel patiënten die goed zelfredzaam (BZR) en sociaal vaardig (PSV) waren als ook de patiënten die slechter op deze indices scoorden, waren meer positief in hun houding ten opzichte van afdeling en instelling, naarmate de psychiatrische opname langer duurde (schema 22 ).

Zoals bij patiënten met lichamelijke handicaps werd opgemerkt, bleek ook bij patiënten die minder goed zelfredzaam (BzR) waren, dat zij een minder positieve houding hadden tegenover hun afdeling en instelling. Deze constatering gelat niet voor patiënten die korter dan vijf jaren waren opgenomen, maar wel. voor patiënten met een langere verblijfsduur.

Van de patienten met een goede BZR- en PSV-score die tevens langer dan twintig jaren waren opgenomen, vertoonde $65 \%$ respectievelijk $74 \%$ een positieve afdelings-en instelingshouding.

Schema 23: Aandeel patiënten (8) met een positieve houding ten opzichte van de afdeling en instelling naar verblijfsduur; interne sociale integratie (ISI) en externe sociale integratie (ESI).

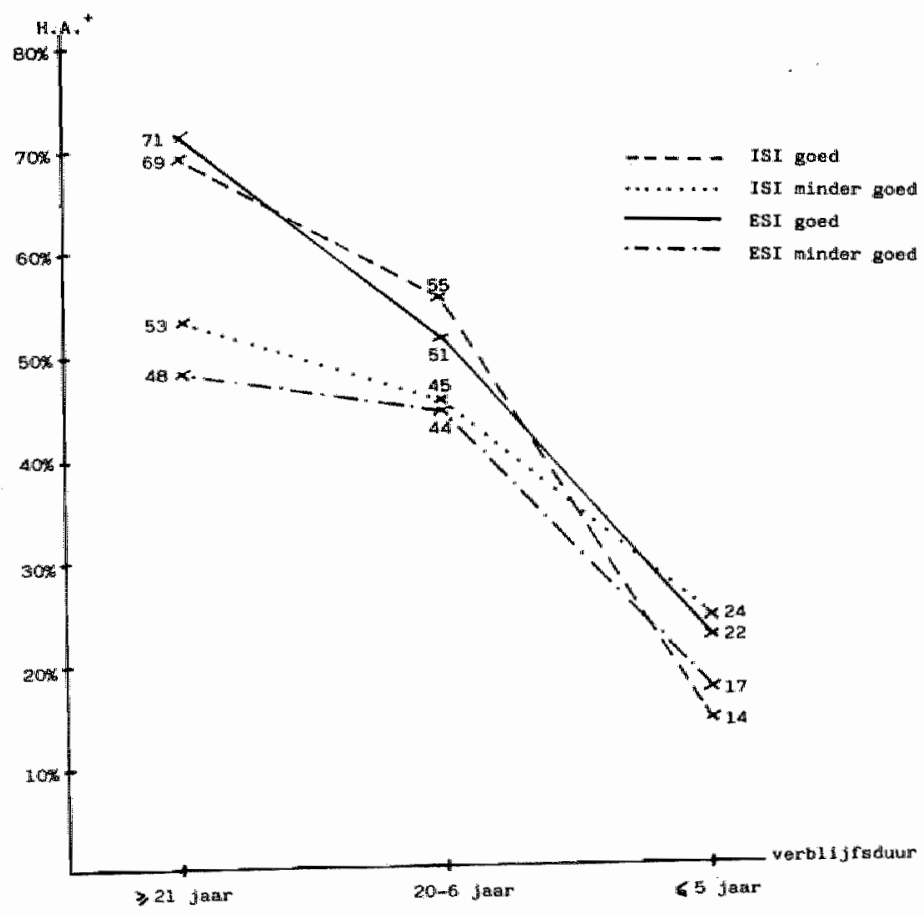


ook voor patidinten die mindex goed binnen (ISI) of buiten (ESI) de insteling aan sociale activiteiten deelnamen kan nat aanleiding van schema 3 : worden geconstateerd dat een langere verbliffaur geparar ging met een positievere houding ten opzichte van de afdeling en instelling.

Tot en met eer verblijfsduur van 5 jaar waren de verschillen tussen de vier subgroepen niet erg groot. Naarmate de opname echter langer duurde, waren vooral de patienten met een grote mate van interne en externe sociale integratie positief over de leefsfeer op de afdeling en in de instelling.

Samenvatting: met uitzondering van gehuwde patiënten, patiënten met een betrekkelijk volledig thuismilieu en patienten zonder agressief gedrag waren de resultaten voor de bestudeerde subgroepen in overeenstemming met de gegevens voor de totale steekproef. Alleenstaande patiënten, en patiënten met een onvolledig thuismilieu, patiënten met enige mate van agressie, mannen en vrouwen, fongere en oudere patiënten, schizofrene patiënten en patienten met een andere psychiatrische diagnose, lichamelijk gehandicapte en lichamelijk niet gehandicapte patiënten, suicidale en nietsulcidale patiënten, patiennten met goede vaardigheden wat betreft BZR, PSV, ISI en ESI en patiënten met minder goede vaardigheden oordeelden positiever over hun afdeling en insteliing narmate zij langer in de insteling verbleven.

\subsection{Houding $t \cdot a \cdot v$. afdeling/instelling en ontslag}

In hypothese 15 worden beide houdingsfactoren aan elkaar gerelateerd. Een positieve houding ten opzlchte van afdeling en instelling zou - zo 1 s de veronderstelling - vooral gepaard gaan met een negatieve ontslaghouding, terwijl een negatieve atdelings- en ilnstellingshouding vooral zou voorkomen bij patiënten die ontslagen willen worden.

H15: Naarmate de houding van lang opgenomen patiënten positiever is tem aanzien van de afdeling en instelling, zullen zilj milinder de wens hebben om ontslagen te worden. 
Tabel 54: Lang opgenomen patiënten in psychiatrische ziekenhuizen naar houding $t .0 . v$. afdeling instelling (H.A.) en houding t.o.v. ontslag (H.O.); percentages.

\begin{tabular}{|c|c|c|c|c|}
\hline H.A. & positief & ambivalent & negatief & totaal \\
\hline positief & 218 & 478 & 588 & 378 \\
\hline ambivalent & 32 & 41 & 39 & 37 \\
\hline negatief & 47 & 12 & 3 & 26 \\
\hline totaal & 1008 & 1008 & 1008 & 1008 \\
\hline totaal abs & 126 & 135 & 31 & 292 \\
\hline
\end{tabular}

Uit de gegevens van tabel 54 blijkt dat de patiënten die hun leefsituatie op de afdeling en in de instelling positief beleefden (kolom 1), eerder negatief (47\%) of ambivalent (328) tegenover een eventueel ontslag stonden dan positief (21:). De omgekeerde relatie kan worden geconstateerd bij de betrekkelijk kleine groep van patiènten $(N=31)$ die hun verblijf als negatief hebben ervaren (kolom 3). De meerderheid (58\%) wilde met ontslag en slechts een enkeling (38) wilde in de insteliing blijven. Conclusie: de resultaten ondersteunen de hypothese dat de houding ten opzichte van de afdeling en de houding ten opzichte van ontslag ongekeerd evenredig aan elkaar gerelateerd zijn. Een positieve afdelings- en instellingshouding gaat veelal gepaard met een negatieve ontslaghouding, en een negatieve houding ten opzichte van de afdeling veelal met een positieve ontslagattitude.

Bil hypothese $13 \mathrm{kon}$ worden geconstateerd dat de ontslaghouding met de duur van de opname meer ambivalent of negatief was. Tevens bleek dat de patiënten bij een langere verblijfaduur de afdeling en de instelling positiever beleefaen (H 15). Omdat de variabele "verblijfsduur" dus zowel gerelateerd is aan de ontslaghouding als aan de afdelingshouaing, is het van belang on voor de drie verblijfsgroepen $(z \cdot 1.0 . p ., 1.0 . p .-c ., 1.0 . p .-d . c$.$) apart na te$ 
gaan of de ongekeerd evenredige relatie tussen de twee houdingsvariabelen blijft bestaan, als gecorrigeerd wordt voor de invloed van verblijfsduur.

Tabel 55: zeer lang opgenomen patienten $(\mathrm{z} .1 .0 . \mathrm{p})$ in psychiatrische ziekenhuizen naar houding $t . a * v$. afdeling instelling (H.A.) en houding t.o.v. ontslag (H.O.): percentages.

\begin{tabular}{|c|c|c|c|c|}
\hline H.A. & positief & ambivalent & negatief & totaal \\
\hline positiof & 208 & 398 & $67 \%$ & 328 \\
\hline ambivalent & 29 & 46 & 33 & 35 \\
\hline negatief & 51 & 15 & $=$ & 33 \\
\hline totaal & $100 \%$ & 100 & $100 \%$ & $100 \%$ \\
\hline totaal abs & 97 & 70 & 18 & 185 \\
\hline
\end{tabular}

Tabel 56: Lang en continu opgenomen patiënten (1.0.p.-c.) in psychiatrische ziekenhuizen naar houding $t . a \cdot v$. afdeling \& instelling (H.A.) en houding t.o.v. ontslag (H.O.); percentages.

\begin{tabular}{lcccc}
\hline H.A. & positief & ambivalent & negatief & total \\
H.0. & & & & \\
\hline positief & 198 & 518 & 408 & 418 \\
amblvalent & 33 & 40 & 50 & 39 \\
negatief & 48 & 9 & 10 & 20 \\
\hline total 8 & 1008 & 1008 & 1008 & 1008 \\
totaal abs & 20 & 43 & 10 & 73 \\
\hline \multicolumn{5}{r}{} \\
\hline
\end{tabular}


Tabel 57: Lang en discontinu opgenomen patienten (1.0.p.-d.c.) in psychiatrische ziekenhuizen nar houding t.o.v. afdeling \& instelling (H.A.) en houding t.a.v. ontslag (H.O.): percentages.

\begin{tabular}{|c|c|c|c|c|}
\hline H. A. & positief & ambivalent & negatief & totaal \\
\hline positief & 338 & 6.88 & 678 & $59 \%$ \\
\hline ambivalent & 56 & 27 & 33 & 35 \\
\hline negatief & 11 & 5 & -- & 6 \\
\hline totaal 운 & 1008 & 1008 & 1008 & 1008 \\
\hline totaal abs & 9 & 22 & 3 & 34 \\
\hline
\end{tabular}

De patiẻnten met een continue verblijfsduur van langer dan 5 jaar $(\mathrm{z} .1 .0 . \mathrm{p}$.$) vormen zowel in onze steekprovef als ook landelijk de$ grootste groep. Vooral de resultaten voor deze groep van patiënten beinvloeden in belangrijke mate de resultaten van de totale steekproef.

Nadere beschouwing van de resultaten voor de z.1.0.p.-groep (tabel 55) leert dat de getrokken conclusie ongewijzigd geldig blijft voor deze patiënten. De tabellen 56 en 57 geven een lets ander beeld te zien. De patiënten die korter dan vijf jaar waren opgenomen (1.0.p.-c. en 1.0.p.-d.c.), bleken veelal reeds bij een ambivalente houding ten opzichte van de afdeling en instelling positief te staan tegenover de mogelijkheid van ontslag. Patiennten met een negatieve afdelingsattitude waren niet positiever in hun ontsligattitude dan patiënten met een ambivalente houding tegenover afdeling en instelling.

\subsection{Behandelingbeleid en ontslagattitude}

In het voorafgaande hoofdstuk bleek dat een positieve beleving van de sfeer op de afdeling en in de instelling veelal gepaard ging met een negatieve en ambivalente houding van de patient ten aanzien van een eventueel ontslag. Omdat dit verschijnsel met 
toenemende verblijfsduur steeds meer bij patiênten voorkomt, zal at femomeen in het vervolg "positieve hospitalisatie" worden genoend:

Dit verschijnsel van positieve hospitalisatie heeft voor patienten, warbij ontslag nog één van de doelstelitingen is, een andere betekenis dan voor patienten waarbij "care"-aspekten op de voorgrond stan.

Bij patienten war "care"-doelstelingen overwegen, voor een belangrijk deel gericht op de leefsfeer (verbetering van woonomatandigheden, privacy, bevorderen van interne contacten e.d.). kan positieve hospltalisatie worden gezien als een bedoeld verschijnsel, - dus als functioneel gezien de doelstelingen van de zorg.

Voor patiénten darentegen warbij ontslag nog één van de doelen is, lijkt positieve hospitalisatie als een onbedoelde ontslagbelemmerende factor te fungeren. De formele doelstelling van ontslag interfereert namelijk met het proces van aanpassing en het gevoel van wardering en zekerheid dat gedurende het verblijf ontstaat; - een proces dat gepaard gat met een geringere wens om buiten het instituut min of meer zelfstandig te leven. Voor deze groep patiënten is positieve hospitalisatie een dysfunctioneel verschijnsel.

Voor hoeveel van de lang opgenomen patiënten was de zorg nog gericht op ontslag nar min of meer zelfstandige huisvesting?

In het onderzoek werd aan de hoofdbehandelaar, maar ook aan een verpleegkundige, verzocht om onafhankeliljk van elkaar per patiënt een oordeel te gever, of zelfstandig wonen of wonen bij familie, gezin of vrienden nog één van de doelen bij de begelleiding en behandeling was. Deze vraag kon met ja of nee worden beantwoord. Door middel van deze vraag was het dus mogelijk om patienten naar de doelstelling van de zorg te onderscheiden. Voor belde groepen beroepsbeoefenaxen is vervolgens nagegaan. welke samenhang bestaat tussen enerzijds de ontslaggerichte doelstelling, zoals geformuleerd door de hulpverleners, en anderzijas de houding van 
ae patiënt ten aanzien van ontslag. De centrale vraag van deze paragraaf is dan ook: sluit de ontslaghouding van de patient aan bij de intenties van de hulpverleners?

H16: Als voor lang opgenomen patiënten door het behandelend personeel wordt aangegeven dat de zorg niet meer gericht is op ontslag, zullen deze patiënten zelf minder de wens hebben om ontslagen te worden dan patienten waarvoor de zorg wel op ontslag is gericht.

Tabel 58: Lang opgenomen patienten naar doelstelling van de zorg (oordeel verpleegkundige) en houding ten aanzien van ontslag; percentages.

\begin{tabular}{|c|c|c|c|}
\hline Hollsteling & $\begin{array}{l}\text { zelfstandig wonen } \\
\text { of wonen bij } \\
\text { anderen }\end{array}$ & $\begin{array}{l}\text { niet zelfstandig } \\
\text { wonen en niet } \\
\text { wonen bij anderen }\end{array}$ & totaa 1 \\
\hline positief & $48 \%$ & 368 & $37 \%$ \\
\hline ambivalent & 488 & 368 & 378 \\
\hline negatief & 48 & 28 욤 & $26 \%$ \\
\hline \multirow[t]{2}{*}{ totaal } & 1008 & 1008 & 1008 \\
\hline & $N=23$ & $N=263$ & $\mathrm{~N}=286$ \\
\hline
\end{tabular}

tau $=-.114 ; \mathrm{s.e.}=.045 ; \mathrm{p}<.01$

Volgens het oordeel van de verpleegkundige was bij $8 \%$ van de geinterviewde patiènten de zorg nog op ontslag gericht (tabel 58). Van deze 23 patiènten had de ene helft een positieve ontslaghouding en was de andere helft ambivalent. Eén patient wilde geheel niet met ontslag.

Het verschil in ontslaggeneigdheld met de grote groep patiënten, warbij zelfstandig wonen en wonen bij familie, gezin of vrienden geen doelstelling voor de hulpverlening meer was, bereikte statistische significantie. Toch had ook van deze patienten nog steeds meer dan éénderde een positieve ontslaghouding. 
De vraag naar de doelstelling van de zorg werd ook gesteld aan de hoofdbehandelaar (psychiater of psycholoog).

Tabel 59: Lang opgenomen patienten nat doelstelling van de zorg (oordeel hoofdbehandelaar) en houding ten anzien van ontslag; percentages.

\begin{tabular}{|c|c|c|c|}
\hline $\begin{array}{l}\text { aolstelling } \\
\text { zorg }\end{array}$ & $\begin{array}{l}\text { zelfstandig wonen } \\
\text { of wonen bij } \\
\text { anderen }\end{array}$ & $\begin{array}{l}\text { niet zelfstandig } \\
\text { wonen en niet } \\
\text { wonen bij anderen }\end{array}$ & totaa 1 \\
\hline positief & 68 & 34.8 & $37 \%$ \\
\hline ambivalent & 21 告 & 398 & 378 \\
\hline negatief & 118 & $27 \%$ & $26 \%$ \\
\hline \multirow[t]{2}{*}{ totaal } & 1008 & 1008 & 1008 \\
\hline & $N=27$ & $N=259$ & $N=286$ \\
\hline
\end{tabular}

De hoofdbehandelaar bleek vooral van mening te verschillen met de verpleegkundige over de patiènten, waarvoor zelfstandig wonen of lnwoning bij anderen (familie/gezin/vrienden) nog doelstelling van de zorg zou zijn. Slechts 12 van de patienten die de hoofdbehandelaar in dit verband noemde, werden ook door de verpleegkundige genoemd. Bij $52 \%$ van deze patiënten bestond dus overeenstemming.

Veel meer consensus bestond ten aanzien van patienten, waarbij de hulpverlening niet meer is gericht op het bereiken van zelfstandig wonen. Van de 263 patienten die in dit verband door de verpleegkundige werden genoema, bestond ten aanzien van 250, afwel 958. overeenstemming. Onafhankelijk van elkar meenden verpleegkundige en hoofdbehandelaar dat voor deze patiënten de hulpverlening niet meer gericht was op ontslag nat min of meer zelfstandige huisvesting.

Tabel 59 lat zien dat van de patienten warvoor de zorg volgens de hoofdbehandelaar nog wel was gericht op ontslag, maar liefst 688 een positieve ontsilagattitude had. Meer nog dan de verpleeg- 
kundige noemde dus de hoofdbehandelaar patiënten warbij de doelstelling "ontsiag en zelfstandig wonen" overeenkwam met een positieve houding ten aanzien van ontslag.

Hoe consistent zijn de bevindingen van tabel 59 voor jongere en oudere patiënten, en patiënten met goede en beperkte sociale varaigheden?

Tabel 60: Lang opgenomen patiënten naar doelstelling van de zorg (oordeel hoofdbehandelaar) en houding ten aanzien van ontslag; percentages.

\begin{tabular}{lll}
\hline zelfstandig wonen & niet zelfstandig \\
of wonen bij & wonen en niet wonen \\
anderen & bij anderen \\
\hline
\end{tabular}

jonger dan 45 jaar

$(\mathrm{N}=86 ; \operatorname{tau}=-.250 ; \mathrm{p} \times .005)$

positief

438

ambivalent

negatief

178

\section{5 jaar en ouder}

$(\mathrm{N}=216 ;$ tau $=-.111 ; p=n . s$.

positief

ambivalent

21 웅

negatief

$21 \%$

goed sociaal vaardig

$(\mathbb{N}=94 ; \tan =-.202 ; \mathrm{p}<.05)$

positief

70 \%

396

ambivalent

$18 \%$

negatief

128

$25 \%$

beperkt sociaal vaardig

$$
(N=206 ; \text { tau }=-.141 ; p<.05)
$$

positief

ambivalent 
De antallen patienten in de onderscheiden subgroepen naar leeftija en sociale varaigheden (PSV *2: PSV $\geq 2$ ) waren klein * vooral voor de patienten, waarvoor de hoofdbehandelaar aangaf dat de zorg nog op zelfstandig wonen was gericht (kolom 1, tabel 60). De resultaten zijn dan ook hoogstens indicatief voor deze subgroepen. Wel vertonen ook de gegevens voor deze subgraepen het xeeds earder geconstateerde patroon. Patienten, waarbij het behandelingsbeleid volgens de hoofdbehandelaar gericht was op ontslag en zelfstandig wonen, hadden in het algemeen zelf ook een meer ontslaggerichte attitude dan patienten die niet behandeld werden met het perspectief op zelfstandig wonen.

\section{11. Doorstroming op de afdeling}

In het voorafgaande zijn instellings- en afdelingsactoren besproken die op patiënt-niveau werden gemeten, zoals verblijfsduur, de beleving van de directe lefongeving door de patiènt en de gerichtheid van de behandeling op ontslag. Deze factoren werden gerelateerd aan de ontslaghouding van de patiënt en het oordeel van hulpverleners over mogelijkheden van ontslag.

In hypothese 17 wordt een nieuw aspect geintroduceerd, namelijk "doorstroming" ofwel "mobiliteit" van medepatiënten op de afdeling. Dit was overigens de enige variabele in het onderzoek die direct op afdelingsniveau werd gemeten. Zo werd voor alle steekproefpatienter nagegaan, of zij op afdelingen verbleven met een relatilef grote of een geringe doorstroomsnelheid. Verwacht werd dat $\mathbb{l}$ ang opgenomen patiënten van afdelingen. waar meer opnemingen en ontslagen platsvonden, eexder voor vervangende zorg werden geindiceerd dan patiênten van afdelingen met een geringe doorstroming.

H17: Naarmate de doorstroming van medepatiënten op de afdeling groter is, komen lang opgenomen patiënten meer in aanmerking voor vervangende zorg. 
Als enige mat voor het aspect doorstroming werd gebruik gemakt van de verblijfsduurcoëfficient. Per afdeling en paviljoen wera berekend hoeveel van de patiënten daar korter dan één jaar verbleven:

$\frac{\text { patiënten }<1 \text { jaar }}{\text { totaal patienten afdeling }} \times 100$

Vervolgens werden de afdelingen onderscheiden nar het percentage patiënten dat langer dan één jaar was opgenomen.

De 381 steekproefpatienten in de vijf psychiatrische ziekenhuizen verbleven samen met andere patiënten in 109 units. Onder het begrip "unit" werden alle ruimtelijk gescheiden wooneenheden van een psychiatrisch ziekenhuis samengevat, hoe verschillend $z i j$ ook waren wat betreft ligging, omvang en begeleidingsprogramma"s. Het ging daarbij om afdelingen, paviljoens (al of niet beheersmatig en organisatorisch onderverdeeld), sociowoningen (op of buiten het terrein) en psychiatrische hostels.

Tabel 61: Aantal units in de 5 psychiatrische ziekenhuizen met steekproefpatienten; naar mate van doorstroming.

\begin{tabular}{|c|c|c|c|}
\hline soort unit & & $\begin{array}{l}\text { aantal } \\
\text { units } \\
(\mathrm{N}=109)\end{array}$ & $\begin{array}{l}\text { aantal } \\
\text { patiënten } \\
(\mathbb{N}=381)\end{array}$ \\
\hline type $1:>70 \%$ & langblijvers (1 jaar ${ }^{+}$) & 72 & 288 \\
\hline type $2: 30-70:$ & langblijvers (1 jaar ${ }^{+}$) & 23 & 72 \\
\hline type $3:<30 \%$ & langblijvers ( 1 jaar $^{+}$) & 14 & 21 \\
\hline
\end{tabular}

ongeveer driekwart van de lang opgenomen patienten woonde in units met een betrekkelijk geringe doorstroming (type 1). De overige steekproefpatienten verbleven in units met een grotere doorstroming.

Inhoeverre bestat nu een samenhang tussen de doorstroming van de unit war de patiënt verbleef en het oordeel van de hulpverleners over vervangende zorg? 
Tabe1 62: Lang opgenomen patienten in psychiatrische ziekenhuizen naar type unit en mogelijkheden van vervangende zorg volgens hulpverlenters; absoluut en percentages.

\begin{tabular}{|c|c|c|c|c|}
\hline & $\begin{array}{l}\text { unit type } 1 \\
>708\end{array}$ & $\begin{array}{l}\text { unit type } 2 \\
30-70 \%\end{array}$ & $\begin{array}{l}\text { unit type } 3 \\
\times 308\end{array}$ & totaa 1 \\
\hline & langblijvers & langbli jvers & langb1ijvers & \\
\hline \multicolumn{5}{|l|}{ vervangende } \\
\hline zorg-groep & $(239)$ & $(548)$ & $(488)$ & $(308)$ \\
\hline \multicolumn{5}{|l|}{ overige } \\
\hline patiênten & 221 & 33 & 11 & 26.5 \\
\hline tataa & $288 \quad(1008)$ & $72(1008)$ & $21 \quad(1008)$ & $381(1008)$ \\
\hline
\end{tabular}

Op de units met de geringste doorstroming (type 1), waar de meeste patienten woonden, werd $23 \%$ van de patiẻnten door de prychitater en verpleegkundige geschikt geacht voor vervangende zorg. De patiënten daarentegen die op afdelingen verbleven, waar meer opnemingen en ontslagen platsvonden (type 2 en 3), kwamen volgens hun hulpverleners meer in aanmerking voor vervangende zorg. De percentages zijn 548 en 488. Hypothese 17 wordt dus gedeeltelijk ondersteund.

Het zou voorbarig zijn om alleen op basis van deze resultaten een oorzakelijk verband te veronderstellen tussen een grotere doorgtroming op de afdeling enerzijds en het vervangende zorg-oordeel van hoofdbehandelaar en verpleegkundige anderzijds. Daarmee zouden de eerder geconstaterde relaties tussen het vervangende zorg-oordeel en bijvoorbeeld leeftija, verblijfsduur of sociale valrdigheden volledig genegeerd worden. 
Tabel 63: Lang opgenomen patiënten naax type unit en verblijfsduurgroep; absoluut en percentages.

\begin{tabular}{|c|c|c|c|c|}
\hline$\therefore \cdots$ & $\begin{array}{l}\text { unit type } 1 \\
>708 \\
\text { langblijvers }\end{array}$ & $\begin{array}{l}\text { unit type } 2 \\
30-70 \% \\
\text { langbli jvers }\end{array}$ & $\begin{array}{l}\text { unit type } 3 \\
\text { 30\% } \\
\text { langbli jvers }\end{array}$ & totaal \\
\hline $\mathrm{z} \cdot 1.0 . \mathrm{p}$ & $(748)$ & $(428)$ & $(298)$ & $(658)$ \\
\hline $1.0 \cdot p \cdot-c$. & $(198)$ & $(368)$ & $(478)$ & $(248)$ \\
\hline $1.0 . p \cdot-d c$. & $(178)$ & $(228)$ & $(248)$ & $42(118)$ \\
\hline totaa 1 & $288(1008)$ & $72(1008)$ & $21 \quad(1008)$ & 381 (1008) \\
\hline
\end{tabular}

Tabe1 63 geeft een indicatie dat de resultaten onder andere vertekend kunnen zijn, doordat de steekproefpatiënten van type 1-units vooral langer zijn opgenomen (74\% verbleef langer dan 5 jaar in de instelling), terwijl de patiënten van type 2 en 3-units vooral een verblijfsduur van korter dan 5 jaar hebben (58\% respectievelijk 718). De vraag naar de relatie tussen doorstroming op de afdeling en het in aanmerking komen voor vervangende zorg zal dus opnieuw moeten worden gesteld, maar dan apart voor:

- jongere en oudere patiënten

- patiënten met goede en minder goede scores op potentiéel sociale vaardigheden, en

- patiënten met een korte en lange verbiljfsduur.

Bij de volgende tabellen $64 \mathrm{t} / \mathrm{m} 68$ werden de patiënten van type 2 en 3-afdelingen, gezien de kleine aantallen patienten, als én groep geanalyseerd. 
Tabel 64: Lang opgenomen patiënten jonger dan 45 jaar naar type unit en mogelijkheden van vervangende zorg; absoluut en percentages.

\begin{tabular}{|c|c|c|c|}
\hline & $\begin{array}{l}\text { wint type } 1 \\
\$ 70 \% \\
\text { langblijvers }\end{array}$ & $\begin{array}{l}\text { unit type } 2 \text { en } 3 \\
\leq 70 \% \\
\text { Langblijvers }\end{array}$ & totaal \\
\hline \multicolumn{4}{|l|}{ vervangende } \\
\hline zorg-groep & $20 \quad(408)$ & $33 \quad(648)$ & $(528)$ \\
\hline \multicolumn{4}{|l|}{ overige } \\
\hline patienten & 30 & 19 & 49 \\
\hline totaa 1 & $50(1002)$ & $52(1008)$ & $102(1008)$ \\
\hline
\end{tabular}

Tabe1.65: Lang opgenomen patiënten van 45 jaar en ouder naar type unit en mogelijkheden van vervangende zorg; absollut en percentages.

\begin{tabular}{|c|c|c|c|}
\hline & $\begin{array}{l}\text { unit type } 1 \\
>70 \% \\
\text { langblijvers }\end{array}$ & $\begin{array}{l}\text { unit type } 2 \text { en } 3 \\
\leq 70 \text { q } \\
\text { langblijvers }\end{array}$ & totaal \\
\hline \multicolumn{4}{|l|}{ vervangende } \\
\hline zorg-groep & $46 \quad(198)$ & $(398)$ & $(228)$ \\
\hline \multicolumn{4}{|l|}{ overige } \\
\hline patienten & 192 & 25 & 217 \\
\hline totaal & 238 (100) & $41(1008)$ & $279(1008)$ \\
\hline
\end{tabular}

De herhaling van de analyse, maar dan apart voor patienten jonger dan 45 jaar en patiênten die 45 jaar en ouder zijn, gaf hetzelfde patroon te zien als tabel 63. Voor beide leeftijasgroepen bleek dat de patiënten van units met een grotere doorstroming eerder in a anmerking kwamen voor vervangende zorg dan de patienten van units met een geringe doorstroming. 
Wel is het nog steeds mogelijk dat de patienten van unlts met een geringere doorstroming, vooral de patiënten $z i j n$ met geringe vardigheden, - patienten die minder kans maken op verwangende zorg. Gezien de grote bijdrage die de PSV-index heeft voor het aordeel over vervangende zorg (hfdst. 12.2.) is bij de meer gedetailleerde analyse voor deze vaardigheidsmat gekozen.

Tabe1 66: Lang opgenomen patienten met goede potentieel sociale vaardigheden (PSV \& 2) naar type unit en mogelijkheden van vervangende zorg; absolut en percentages.

\begin{tabular}{|c|c|c|c|}
\hline$\vdots$ & $\begin{array}{l}\text { unit type } 1 \\
>70 \% \\
\text { langblijvers }\end{array}$ & $\begin{array}{l}\text { unit type } 2 \text { en } 3 \\
\leq 70 \% \\
\text { langblijvers }\end{array}$ & totaal \\
\hline \multicolumn{4}{|l|}{ vervangende } \\
\hline zorg-groep & $25 \quad(43 \%)$ & $35 \quad(738)$ & $(578)$ \\
\hline \multicolumn{4}{|l|}{ overige } \\
\hline patiënten & 33 & 13 & 46 \\
\hline totaal & $58(1008)$ & $48(1008)$ & $106 \quad(1008)$ \\
\hline
\end{tabular}

Tabel 67: Lang opgenomen patiënten met beperkte potentieel sociale varardigheden (PSV $\geq 2$ ) max type unit en mogelijkheden van vervangende zorg; absoluut en percentages.

\begin{tabular}{|c|c|c|c|}
\hline & $\begin{array}{l}\text { unit type } 1 \\
>708 \\
\text { langblijvers }\end{array}$ & $\begin{array}{l}\text { unit type } 2 \text { en } 3 \\
\leq 70 g \\
\text { langblijvers }\end{array}$ & totaa 1 \\
\hline \multicolumn{4}{|l|}{ vervangende } \\
\hline zorg-groep & $42 \quad(18 \%)$ & $14 \quad(338)$ & $56(218)$ \\
\hline \multicolumn{4}{|l|}{ overige } \\
\hline patienten & 188 & 28 & 216 \\
\hline totaal & $230(1008)$ & $42(1008)$ & 272 (1008) \\
\hline
\end{tabular}


Uit de tabellen 66 en 67 wordt duidelijk dat het verschil in doorstroming in de unit ook bij patiënten met dezelfde sociale vaardigheden (PSV) tot uiting kwam in verschilien in indicatiesteliling voor vervangende zorg. Patienten die goede (potentieel) sociale vardigheden hadden, mar die in units verbleven met weinig doorstroming, werden door hun hulpverleners minder valk (43\%) voor verwangende zorg ingedeeld dan patienten met vergelijkbare PSW-scores (73\%) in units war relatief veel doorstroming platswond. De resultaten van tabel 67 wijzen op hetzelfde fenomeen, maar dan voor patiēnten met beperkte sociale vaardigkeden. Ook deze patiẻnten hadden in units waar nog betrekkelijk veel opnemingen en ontslagen plaatsvonden, een grotere kans on voor vervangende zorg in a anmerking te komen, dan patienten in units met weinig doorstroming.

Een eerdere tabel (tabel 63) liet zien dat zeer lang opgenomen patiënten ( $>5$ jaar) vooral in units verblewen met een geringe doorstroming (type 1), en de patiënten met een kortere verblijfsduur $(1.0 . \mathrm{P} .-\mathrm{c}$. en 1.0.p.-dc.) vooral waren opgenomen in units met meer doorstroming (type 2 en 3). Daarom werd apart per verbliffiduurgroep onderzocht, of lang opgenomen patiënten die in doorstroomunits (type 2 en 3) verbleven, eerder werden ingedeeld voor vervangende zorg dan patiënten in units met weinig doorstroming (type 1). In de overzichtstabel 68 is dit per verblijfsduurgroep nagegaan voor patiënten met goede en beperkte sociale vaardigheden, en jongere en oudere patiënten. 
Qverzichtstabel 68: Aamdeel patiënten (8) dat per type afdeling in aanmerking komt voor vervangende zorg; percentages.

$\frac{\text { unit type } 1}{>70 \%} \frac{\text { unit type } 2 \text { en } 3}{\leq 70 \%}$
langblijwers langblijvers

zeer lang opgenomen patiënten ( $>5$ jr.)

- met PSV <2 $(N=46)$

38 웅

648

$-\operatorname{met} P S V \geq 2 \quad(N=200)$

148

308

-445 jaar $(\mathrm{N}=37)$

268

708

-25 jaar $(\mathrm{N}=211)$

$16 \%$

31 음

lang en continu opgenomen patiënten

(2-5 jaar)

- met $\mathbb{P S V}<2 \quad(\mathrm{~N}=34)$

368

80 응

- met PSV $\geq 2 \quad(N=56)$

328

40 웅

$-<4$ jaar $(\mathrm{N}=36)$

$42 \%$

678

-245 jaar $\quad(N=55)$

30 용

50 영

lang en discontinu opgenomen patiënten

- met PSV < $2 \quad(N=26)$

$67 \%$

71 영

- met PSV $\geq 2 \quad(\mathrm{~N}=16)$

4.48

298

$-<45$ jaar $\quad(\mathrm{N}=29)$

$73 \%$

568

$-\geq 45$ jaar $\quad(N=13)$

$40 \%$

678

Bij de verblijfsduurgrcepen langer dan 5 jaar ( $z \cdot 1.0 . p$.$) en 2$ tot 5 Jaar (1.0.p.-c.) kwam wederom hetzelfde beeld naar voren: de patiènten die in doorstroomunlts waren opgenomen, werden zelf ook eerder aoor de hoofdbehandelaar en verpleegkundige genoemd voor vervangende zorg. En dat gold woor zowel jongere als oudere patiënten, en patiënten met goede en beperkte sociale vaardigheden.

Voor de patiënten die door middel van meer opnemingen in een periode van vijf jaar langer dan 3 jaar in het psychiatrisch 
ziekenhuts verbleven (1.0.p.-dc.), zign de resultaten minder duidelijk, of zelfs strijdig met dile voor de andere verblijfsduurgroepen. Zo hadden de jonge patienten van deze verblijfsdurgroep (1.0.p.-dc.) en de patiënten uit dezelfde groep met beperkto sociale vardigheden meer kans op vervangende zorg in type 1-units, dan in units van het type 2 en 3 . Bij verdere interpretatie of generalisatie zal echter rekening moeten worden gehouden met het geringe aantal discontinu opgenomen patiënten (1.0.p.dc.) in de steekproef.

Conclusie: hypothese 17 werd gedeeltelijk door de resultaten van dit onderzoek ondersteund. Lang opgenomen patiënten die in units verblijven met enige doorstroming (type 2) kwamen eerder voor vervangende zorg in aanmerking dan patiënten die in units verblifven met een geringe doorstroming. Dit resultat werd nog eens bevestigd voor patienten met een verblijfsduur van 5 jaar of langer en voor aie van 2 tot 5 jaar met controle op de variabelien "leeftijd" en "sociale vaardigheden". Patienten die op afdelingen verbleven met een nog grotere doorstroming (type 3), werden daarentegen niet méér genoemd in verband met vervangende zorg dan patiënten van type 2-afdelingen.

\subsection{Volledigheid thuismilieu}

In de vakliteratuur worden lang opgenomen patiënten beschreven als saciaal geisoleerde en betrekkelijk eenzame mensen. In het onderhavige onderzoek werd dit aangetoond voor zowel contacten en activiteiten op de afdeling en binnen de insteliing (ISI) als ook voor contacten met personen dile buiten de instelling wonen (ESI). Bij de items van het concept externe sociale integratie (ESI) werden vooral de vragen die niet direct betrekking hadden op het sociale netwerk buiten de instelling (kemnissen, vrienden, fami1ㄴ, werk). nog betrekkelijk vaak in positieve zin beantwoord (tabel 22). Het gat daarbij om activiteiten als wandelen buiten het instellingsterrein, televisie kijken, meedoen aan uitstapjes die door de instelling worden georganiseerd, boodschappen doen. 
op vacantie gaan, kranten en tijaschriften lezen, en praten met personeel over gebeurtenissen (via krant, radio en televisie) die buiten de instelling hebben platsgevonden.

De items die betrekking hadden op contacten van patienten met leden van het sociale netwerk buiten de instelling, werden aanzienlijk minder vaak positief beantwoord. Zo nam $26 \%$ van de patiênten meer dan twee keer in de maand telefonisch contact op met kennissen, vrienden of familie, $28 \%$ één of twee keer in de maand, en $46 \%$ mooit. Nog minder werd men zelf door kennissen. vrienden of familie opgebeld. Zo telefoneerden bij 178 wan de patiënten kennissen, vrienden of familieleden meer dan twee keer in de maand, en 418 één of twee keer. Bijna tweederde van de patiënten schreef nooit brieven of kaarten, en 43 ontving nooit post.

Driekwart van de patiènten (748) bleef nooit of zeer zelden het gehele weekend bij familie, vrienden of kennissen, en tweederde (68\%) ging nooit midden in de week op bezoek bij personen die buiten de instelling woonden.

De lang opgenomen patiënten ontvingen ook zelf weinig bezoek. Van de patiënten kreeg 20 meer dan twee keer in de maand bezoek van personem die buiten de instelling woonden, $41 \%$ werd één of twee keer in de maand bezocht, terwijl 398 van de patiënten nooit of zelden bezoek ontving.

Bovenstaande bevindingen wijzen erop dat tussen de patient en het primaire thuismilieu, zoals ouders, broers en zusters, echtgenoot af echtgenote en kinderen, weinig contact bestaat. De vrag echter, of de contactfrequentie gedurende de periode van opname minder is geworden, kan niet op basis van dit onderzoek worden beantwoord, daar de gegevens alleen betrekking hebben op een momentopname. Het is een schets van de situatie na jarenlange opname. Hoe de banden en contacten met het primalire thui wilieu tijdens en kort na de opname waren, welke processen van acceptatie en uitstoting hebben gespeeld, is dus niet an de hand van dit transversale onderzoek na te gaan. Hiervoor zijn longitudinale gegevens noodzakelijk, met andere woorden: procesbeschrijwingen van opnamecohorten. 
In dit onderzoek is wel nagegaan, inhoeverre lang opgenomen patienten, gezien hun veelal gevorderde leeftija, nog over een primair thuismilieu beschikten. Hoeveel van de lang opgenomen patienten hadden op het tijdstip van onderzoek nog levende ouders, broers en zusters, een huwelijkspartner of kinderen?

Het onderzok gaf het volgende beeld te zien. Van de lang opgenomen patienten had $66 \%$ geen levende ouders meer, bij $18 \%$ was nog én wan de ouders in leven, terwijl $16 \%$ nog over beide ouders beschikte. De meeste patiënten (88\%) waren niet gehuwd, 128 had dus wel een echtgenoot/echtgenote.

De gegevens over het aantal levende broers en zusters waren. helaas onvolledig. Zo was voor 54 van de 381 patienten orbekend of zij broers of zusters hadden. Van de overige patiënten bleek 708 nog twee of meer levende broers en/af zusters te hebben, $19 \%$ had éen broer of zuster en 11 q had geen broers of zusters. Wat betreft het aantal kinderen, was bij 10 patiënten geen informatie beschikbaar. Van de overige 371 patiénten had 738 geen kinderen, terwijl $\mathrm{Bq}$ één kind had en 198 van de patiènten twee of meer kinderen.

In tabel 69 is vervolgens de samenstelling van het primaire thuismilieu geschetst. Voor 313 patiënten van de steekproef was de informatle volledig. 
Tabe1 69: Lang opgenomen patienten in psychiatrische ziekenhulizen naar volledigheid thuismilie en indeling voor vervangende zorg: percentages.

\begin{tabular}{|c|c|c|c|c|c|c|c|}
\hline & $\begin{array}{l}\text { ou- } \\
\text { ders }\end{array}$ & $\begin{array}{l}\text { broers/ } \\
\text { zusters }\end{array}$ & $\begin{array}{l}\text { part- } \\
\text { ner }\end{array}$ & $\begin{array}{l}\text { kinde- } \\
\text { ren }\end{array}$ & $\begin{array}{l}\text { totaal } \\
(N=31.3)\end{array}$ & $\begin{array}{l}\text { vervangende } \\
\text { zorg-groep } \\
(\mathrm{N}=102)\end{array}$ & $\begin{array}{l}\text { overige } \\
\text { patiënten } \\
(\mathrm{N}=211)\end{array}$ \\
\hline (a) & + & + & + & + & 1.38 & 1,08 & 1,48 \\
\hline (b) & + & + & + & - & 0,6 & 1,0 & 0.5 \\
\hline$(c)$ & + & + & - & + & 3,5 & 7,8 & 1,4 \\
\hline (d) & + & + & - & - & 31,9 & 43,1 & 26.5 \\
\hline (e) & + & - & + & + & 0,3 & -- & 0.5 \\
\hline (f) & + & - & + & - & -- & -- & -- \\
\hline$(g)$ & + & - & - & + & -- & -- & $-\infty$ \\
\hline$(\mathrm{h})$ & + & - & - & - & 1,0 & -- & 1.4 \\
\hline (i) & - & + & + & + & 3,5 & 1,0 & 4.7 \\
\hline$(j)$ & - & + & + & - & 0.6 & - & 0.9 \\
\hline$(k)$ & - & + & - & + & 10,9 & 14,7 & 9,0 \\
\hline (1) & - & + & - & - & 37,4 & 26,5 & 42,7 \\
\hline$(m)$ & - & - & + & + & 1,6 & -- & 2,4 \\
\hline$(n)$ & - & - & + & - & 1,0 & 1,0 . & 0,9 \\
\hline$(0)$ & - & - & - & + & 1,9 & 1,0 & 2,4 \\
\hline \multirow[t]{2}{*}{$(p)$} & - & - & - & - & 4,5 & 2,9 & 5,2 \\
\hline & & & & & 100,08 & $1.00,08$ & 100,08 \\
\hline
\end{tabular}

* = tenminste één familielid nog în leven

- geen familielid in leven

Wooral drie thuismilieusituaties kwamen bij de patiënten veel yoor:

(1) patiënten die geen levende ouders meer hebben, maar wel tenminste één broer of zuster; er is geen huwelijkspartner en er $z i j n$ geen kinderen $(37 \%)$;

(d) patiënten die nog tenminste én levende ouder en broer/zuster hebben, maar niet gehuwd zijn en ook geen kinderen hebben $(32 \%) ;$ en

(k) patiënten die geen levende ouders hebben, maar wel levende broers/zusters; ze zijin niet (meer) gehuwd en hebben wel tenminste één kind (118). 
De meest extreme situatie, warbij geheel geen primair thuismilieu beschikbaar is, dus geen ouders, geen broers of zusters, geen huwelijkspartner en geen kinderen $(p)$, kwam bij slechts $4 \%$ van de patienten voor.

Naar aanleiding van tabel $69 \mathrm{kan}$ worden opgemerkt dat vooral de patienten die levende ouders en broers/zusters hadden (d) volgens hun hulpverleners in aammerking kwamen voor vervangende zorg (kolom 2). De patienten daarentegen waarbij van het primaire milleu alleen nog broers en/of zusters waren overgebleven (1) werden van de d-ie grote groepen het minst genoemd voor vervangende zorg.

H18: Naarmate het thuismilieu van lang opgenomen patiënten vollediger is, komen $z i j$ eerder in a anmerking voor vervangende zorg.

Ten behoeve van de operationalisering van het begrip "volledigheld thuismilieu" was het noodzakelijk om een continue variabele te construeren voor het aantal levende familieleden.

De enkelvoudige vragen naar het aantal levende ouders, broers en zusters, en kinderen waren in het onderzoek door de hoofdbehandelaar beantwoord als 0-geen, 1 -één en 2 -meer dan één (VOL I). De vraag naar het gehuwd zijn of "duurzaam samemwonen ( 6 maanden)" kende daarentegen slechts twee antwoordcategoriën: 0-nee en 1-ja. Naar aanleiding van bovenstande hypothese werd een somscore berekend per patient voor de vier items tezamen. Deze varieerde van 0 tot 8 (en niet van 0 tot 7). Bij aanurezigheia van een huwelijkspartner werd namelijk een score van 2 in plats van 1 toegekand.

Met de introductie van de somscore werd zo een poging ondernomen om het aantal structuurelementen in het primaire thuismilieu te kwantificeren. Deze mat geeft echter geen indruk van het aantal werkelijke contacten en de betekenis van familieleden voor de betrokken patijut. Jonge ouders die in de buurt van het psychiatrisch ziekenhuis zelfstandig gehuisvest zijn, met voldoende araagkracht bij emotionele belastingen en een aanvaardende hou- 
aing ten opzichte van de patient, hebben dezelfde score $(=2)$ a 15 de wader en moeder die vanwege hun leeftija in een verzorgingstehuis verblijven op een zeer grote reisafstand.

Een somscore impliceert ook zeex verschillende thuismilieusituaties. Als voorbeeld: een somscore van $4 \mathrm{kan}$ de volgende combinaties van levende familieleden betekener:

- partner, beide ouders

- partner, twee of meer broers/zusters

- partner, twee of meer kinderen

- beide ouders, twee of meer broers/zusters

- beide ouders, twee of meer kinderen

- twee of meer broers/zusters, twee of meer kinderen

- partner, vader of moeder, broer of zuster

- partner, vader of moeder, één kind

- partner, broer of zuster, één kind

- belde ouders, broer of zuster, één kind

- twee of meer broers/zusters, vader of moeder, éen kind

- twee of meer kinderen, vader of moeder, broer of zuster.

Na deze operationalisering van het begrip "volledigheid thuismilieu" was het mogelijk am hypothese 18 te toetsen. Bestond bij lang opgenomen patiënten een samenhang tussen de volledigheid van het primaire thuismilieu en de indicatiestelling voor vervangende zorg? 
Tabel 70: Lang opgenomen patiënten in psychlatrische ziekenhuizen natr volledigheid thuismilieu en mogelijkheden van vervangende zorg; absoluut en percentages.

\begin{tabular}{|c|c|c|c|c|c|c|c|}
\hline \multirow[b]{2}{*}{ vervangende } & \multicolumn{2}{|l|}{$0-2$} & \multicolumn{2}{|l|}{$3-5$} & $6-8$ & \multicolumn{2}{|c|}{ totaal } \\
\hline & & & & & & & \\
\hline zorg-groep & 40 & $(258)$ & 58 & $(418)$ & $(578)$ & 102 & (338) \\
\hline \multicolumn{8}{|l|}{ overige } \\
\hline patiënten & 123 & & 85 & & 3 & 211 & \\
\hline totaal & 163 & $(1.000)$ & 143 & $(1008)$ & $7(1008)$ & 313 & $(1008)$ \\
\hline
\end{tabular}

In eerste instantie wordt de hypothese ondersteund (tabel 70). De patiẻnten met een onvolledig thuismilieu (vooral patiënten met alleen broers en/of zusters) werden minder ingedeeld voor vervangende zorg dan patiénten die daarnaast ook nog andere levende familieleden hadden.

Een mogelijke verklaring voor dit resultat is dat het een artefact betreft van de variabele "leeftijd". In hoofdstuk 12.5. kon worden opgemerkt dat jongere patiënten eerder in aanmerking kwamen voor vervangende zorg dan oudere patienten. Tevens mag worden aangenomen dat jongere patiënten over meer levende familieleden beschikken. Het is dus mogelijk dat bij controle op de invloed van de variabele "leeftijd" het verband tussen "volledigheid thuismilieu" en de indicatiesteliling voor vervangende zorg verdwijnt. 
Tabel 71: Lang opgenomen patiënten jonger dan 45 jaar naar volledigheid thuismilieu en mogelijkheden van vervangende zorg; absolut en percentages.

\begin{tabular}{|c|c|c|c|}
\hline & $0-2$ & $3-8$ & totaal \\
\hline \multicolumn{4}{|l|}{ vervangende } \\
\hline zorg-groep & $12(608)$ & $(518)$ & $(538)$ \\
\hline \multicolumn{4}{|l|}{ overige } \\
\hline patiënten & 8 & 35 & 43 \\
\hline totaal & 20 (1008) & $72(1008)$ & $92(1008)$ \\
\hline
\end{tabular}

Tabel 72: Lang opgenomen patiënten van 45 jaar en ouder naar volledigheid thuismilieu en mogelijkheden van vervangende zorg: absoluut en percentages.

\begin{tabular}{lcccccc}
\hline & $0-2$ & $3-8$ & totaal \\
\hline $\begin{array}{l}\text { vervangende } \\
\text { zorg-groep }\end{array}$ & 28 & $(20 \%)$ & 25 & $(328)$ & 53 & $(248)$
\end{tabular}

overige

\begin{tabular}{lllll} 
patiënten & 115 & 53 & 168 \\
totaal & $143(1008)$ & $78(1008)$ & $221(100 \%)$ \\
\hline & $\operatorname{tau}=-.156 ;$ & s.e. $=.077 ; \mathrm{p}<.05$
\end{tabular}

Bij de patienten jonger dan 45 jaar bleek dit het geval te zijn (tabel 71). De verschilien waren klein, en eerder in het voordeel voor patiënten met weinig levende familieleden. De patiënten van 45 jaar en ouder daarentegen (tabel 72) met een relatief orvolledig thuismilieu $\mathrm{kwamen}$ nog steeds minder in aanmerking voor vervangende zorg. Bij een verdere onderverdeling van 45 tot 65 jarigen en 65 jaar of ouder was echter ook hier nauwelijks meer een verschil te constateren.

Conclusie: patiënten met betrekkelijk veel levende familieleden kwamen eerder in a anmerking voor vervangende zorg dan patiënten met minder familieleden. Deze relatie kan echter grotendeels verklaard worden door verschillen in leeftijd. 
In het voorgaande is gekeken naar de anwezigheid van een primalt thuigmilieu. En darbij bleek dat vooral de vele oudere lang opgenomen patienten van de steekproef nog mar weinig levende familieleden hadden. Zo had 65 tran de patiënten die 45 jaar of ouder waren, een somscore var $0 \mathrm{t} / \mathrm{m} 2$ op volledigheid van het thuismilieu (tabel 72), wat voor het merendeel van de patienten betekende dat men alleen nog over levende broers en/of zusters beschikte. De structurele component, het aantal familieleden, bleek na controle op de invloed van leeftijd weinig bij te aragen tot de verklaring, waarom patiẻnten wel of niet door hun hulpverleners geindlceerd werden voor vervangende zorg.

Dan resteert nog de vraag naar de houdingscomponent. Bestaat er een relatie tussen de houding van familieleden ten aanzien van eventueel ontslag nar de thuissituatie en de vervangende zorgindicatie van hulpverleners"?

H19: Naarmate het thuismilieu van lang opgenomen patiënten een negatiever houding inneemt ten aanzien van eventueel ontslag naar de thuissituatie, komen de patiènten minder voor vervangende zorg in aanmerking.

In het onderzoek beschikken wij ten aanzien van de houding van familieleden alleen over een taxatie van de hoofdbehandelaax. De familieleden werden dus niet apart in verband met deze vraag benaderd. Zo moest in het kadex van het totaal van vraagstellingen van dit onderzoek een afweging worden gemakt tussen enerzijds kwaliteit van informatie voor deze deelvraag en anderzijas de daarmee gepaard gaande extra tijdsbesteding en kosten. Omdat in het onderzoek reeds gebruik werd gemaakt van arie bronnen voor informatie, namelijk de hoofdbehandelaar, een verpleegkundige en de patient zelf, was uitbreiding van het soort respondenten met teminste vier andere, te weten ouder(s), broer(s) of zuster(s). huwelijkspartner en kind(eren) practisch niet hadbaar. Het zou het onderzoek te arbeidsintensief en kostbaar gemaakt hebben. 
De hoofdbehandelaar kreeg in het kader van de voL $I$ vier vragen woorgelegd, namelijk over de houding van ouders, van broers/zusters; van echtgenoot/echtgenote en van kinderen ten aanzien van eventuele inwoning of wonen in de naste omgeving. Voor de vragen bestonden de volgende geprecodeerde antwoordmogel ijkheden: aanvaardend, ambivalent, afwerend en onbekend.

Het aantal patiënten waarvoor de houding van familieleden niet door de hoofdbehandelaar kon wordem beantwoord (= onbekend). varieerde van $16 \%$ voor de echtgenoot of echtgenote tot $22 \%$ voor de broers/zusters. Indien de betrokken patient meer broers of zusters had, of meer kinderen, dan werd geadviseerd om de houdingsvraag te beantwoorden voor die familieleden, waarmee de patiënt het meeste contact heeft.

In de tabellen $73 \mathrm{t} / \mathrm{m} 76 \mathrm{zijn}$ vervolgens de resultaten weergegeven voor de eventuele relatie tussen de houding van familieleden ten aanzien van eventuele unwoning of wonen van de patient in de naaste omgeving en de indicatiestelling voor vervangende zorg.

Tabel 73: Lang opgenomen patiënten in psychiatrische ziekenhulizen naar houding ouders tegenover eventueel ontslag en mogelijkheden van vervangende zorg; absoluut en percentages.

\begin{tabular}{|c|c|c|c|c|}
\hline & aanvaardend & ambivalent & afwerend & totaal \\
\hline \multicolumn{5}{|l|}{ vervangende } \\
\hline zorg-groep & $(558)$ & $(508)$ & $(458)$ & $(478)$ \\
\hline \multicolumn{5}{|l|}{ overige } \\
\hline patienten & 5 & 15 & 36 & 56 \\
\hline totaal & $11(1008)$ & $30(1008)$ & $65(1008)$ & $106(100 \%)$ \\
\hline
\end{tabular}


Tabel 74: Lang opgenomen patienten in psychiatrische ziekenhizem nar houding broer of zuster tegenover eventueel ontslag en mogelijkheden van vervangende zorg; absoluut en percentages.

\begin{tabular}{|c|c|c|c|c|}
\hline & W a numa $r d$ dend & ambivalent & a fwerend & totaal \\
\hline \multicolumn{5}{|l|}{ vervangende } \\
\hline zorg-groep & $(350)$ & $(318)$ & $(368)$ & $(35 \%)$ \\
\hline \multicolumn{5}{|l|}{ overige } \\
\hline et1snten & 17 & 22 & 107 & 146 \\
\hline totara 1 & 26. $(1000)$ & $32(100 \%)$ & 167 (100\%) & $225(1006)$ \\
\hline
\end{tabular}

Tabel 75: Lang opgenomen patienten in psychiatrische ziekenhulzen nair houding echtgenoot/echtgenote tegenover eventueel ontslag on mogelijkheden van vervangende zorg; absoluut en porcentrges.

\begin{tabular}{|c|c|c|c|c|}
\hline & arvardend & ambivalent & afwerend & totaal \\
\hline \multicolumn{5}{|l|}{ vervangende } \\
\hline zorg-groep & $(258)$ & $(258)$ & $(138)$ & $(138)$ \\
\hline \multicolumn{5}{|l|}{ overige } \\
\hline patienten & 3 & 3 & 26 & 32 \\
\hline totaa 1 & $4(1008)$ & $4(1008)$ & $30(100 \%)$ & $38 \quad(100 \%)$ \\
\hline
\end{tabular}


Tabel 76: Lang opgenomen patienten in psychiatrische ziekenhuizen naar houding kinderen tegenover eventueel ontslag en mogelijkheden van vervangende zorg; absoluut en percentages.

\begin{tabular}{|c|c|c|c|c|c|c|}
\hline & & nvaardend & amb & ivalent & afwerend & totaal \\
\hline \multicolumn{7}{|l|}{ vervangende } \\
\hline zorg-groep & 4 & $(448)$ & 11 & $(398)$ & (238) & $(318)$ \\
\hline \multicolumn{7}{|l|}{ overige } \\
\hline patienten & 5 & & 17 & & 34 & 56 \\
\hline totaal & 9 & $(1008)$ & 28 & $(1008)$ & $44(1008)$ & $81 \quad(1000)$ \\
\hline
\end{tabular}

De resultaten voor de ouders, broers/zusters, partner of kinderen ondersteunden de gestelde hypothese niet. Bij de indicatiestelling voor vervangende zorg door de hulpverleners bleek het weinig ulit te maken, hoe de opstelling van het primaire thuismilleu was ten aanzien van eventuele inwoning of wonen in de directe ongevilng van familieleden.

12.13. De invloed van enkele variabelen tezamen op het oordeel over vervangende zorg; een multivariaat model.

In het voorgaande werden een aantal hypothesen getoetst waarbij een verband werd verondersteld tussen één variabele (bv. PSV) en het oordeel van hulpverleners over de mogelijkheid van vervangende zorg. Voor enkele hypothesen $(1 \mathrm{t} / \mathrm{m}$ 8) werd tevens nagegaan of de resultaten verklaard kumen worden door een derde variabele. bijvoorbeeld leeftija.

Met behulp van multiple logistische regressie is het mogelijk om de invloed te meten van meerdere variabelen teamen op het oordeel over vervangende zorg. Ook kan in een model binnen het totaal van de gespecificeerde varlabelen worden bepaald welke variabelen het meeste bijdragen tot een positief oordeel. Daarbij is wel wan belang dat het madel de verzamelde gegevens goed beschrijft, en dat het zo eenvoudig magelijk is. 
De logistische regressie is stapsgewijs uitgevoerd (BMDP-LR) voor 247 patienten warvan ook de gegeven van de voL II I beschikbaar waren.

Niet alle vaxiabelen zoals genoemd in de hypothesen en samengevat in schema 7 en 8 (hfdst. 6) waren in deze analyse opgenomen. Zo werd nar anleiding van de resultaten van de cross-classiflicatie alleen gebruik gemakt van de PSV-index als indicator poor de varaligheden. De redenen hiervoor waren de hoge lineaire samenhang met de andere drie vaardigheidsvariabelen (BZR, ISI en ESI), als ook de relevantie als enkelvoudige variabele bij de toedeling van patienten die wel of niet voor vervangende zorg in aanmerking kwamen.

Bij andere varjabelen zoals organische psychische stoorris, surcidal gedrag, onvrijwillige opname en houding van het thuismilieu werd bij bivariate toetsing geen statistisch significant verband geconstateerd met de afhankelijke variabele "vervangende zorg", en was tevens het aantal. waarnemingen betrekkelijk gering. ook deze variabelen zijn buiten het beginmodel gelaten.

Tabel 77: Specificatie van de onathankelijke variabelen in het beginmodel van de logistische regressie.

\begin{tabular}{|c|c|c|c|c|c|}
\hline variabele & & min. & $\max$ & $\mathrm{x}$ & s.a. \\
\hline - leeftijd & $(\mathrm{LFT})$ & $21 \mathrm{j}$. & $85 \mathrm{j}$. & 53,4 & 15,5 \\
\hline - sociale vaardigheden & (PSV) & 0 & 8 & 3,2 & 2,6 \\
\hline - volledigheld thuismilieu & $(\mathrm{THM})$ & 0 & 7 & 2.7 & 1,3 \\
\hline - agressiviteit & (AGR) & 0 & 8 & 1,8 & 2,0 \\
\hline - verblijesduur & (VBD) & $1 \mathrm{j}$. & $53 j$ & 39.7 & 12,6 \\
\hline - doorstroming afdeling & (DOA) & 1 & 3 & -- & -- \\
\hline - houding $t \cdot a * v$. afdeling & $(\mathrm{HA})$ & 1 & 4 & 2,8 & 0,6 \\
\hline - houding $t \cdot a \cdot v \cdot$ ontslag & (HO) & 1 & 4 & 2.6 & 0,8 \\
\hline \multirow[t]{2}{*}{ - schizotrenie } & $(S Z F)$ & nee $=$ & 1 & & \\
\hline & & ja & 2 & & \\
\hline
\end{tabular}


Hiermee bleef een negental onafhankelijke variabelen over voor de logistische regressie (tabel 77). Eén van deze variabelen, de alagnose "schizofrenie" of "anderszins" " was categoriaal van aard. De variabelen waren onderling niet sterk gerelateerd (bijlage 6) met uitzondering van het verband tussen leeftijd en verblijfsduur $(r=.53)$.

Na specificatie van de variabelen kon het beginmodel voor de logistische regressie als volgt worden geformuleerd:

$y=\log \left(\frac{P}{I-P}\right)=a+b \cdot L F T+c \cdot P S V+d \cdot T H M+e \cdot A G R+f \cdot V B D+g \cdot D O A+h \cdot H A+d \cdot H O+j \cdot S Z F$

In het geheel waren vier stappen nodig om een model te vinden dat een redelijke tot goede beschrijwing gaf van de verzamelde gegevens en dat betrekkelijk eenvoudig te interpreteren was door een beperkt aantal variabelen en afwezigheid van interactie-termen (tabel 78).

Tabe1.78: Resultaten voor "fitting" van verschillende versles van het lineaire logistische model op de gegevens.

\begin{tabular}{|c|c|c|c|c|}
\hline Stap & Madel & $\mathrm{DF}$ & $\begin{array}{l}\text { Goodness-of-fit } \\
\text { Chi-square (G) }\end{array}$ & $\mathrm{P}$ \\
\hline 1: & PSV & 244 & 279.7 & .058 \\
\hline $2:$ & $\begin{array}{l}\text { LFT } \\
\text { PSV }\end{array}$ & 243 & $269, \mathbb{1}$ & .120 \\
\hline 3: & $\begin{array}{l}\text { LET } \\
\text { PSV } \\
\text { HA }\end{array}$ & 242 & 261,6 & .185 \\
\hline 4: & $\begin{array}{l}\mathrm{LFT} \\
\mathrm{PSV} \\
\text { SZF } \\
\mathrm{HA}\end{array}$ & 241 & 257.8 & .219 \\
\hline
\end{tabular}


Het resultat van de logistische regressie werd niet beinvloed door het feit, of van de ruwe data werd uitgegaan, of van gestratificeerde of van categoriale gegevens. Steeds werden in de vierde stap dezelfae vier varlabelen gevonden.

Vooral van de saclale varaigheden, de leeftija, de houding van de patient ten aanzien van de afdeling en de diagnose schizofrenile bleek het af te hangen, welke patiënten wel en welke niet. volgens hun hulpverleners in aanmerking kwamen voor vervangende zorg.

zoals eerder in hoofdstuk 12.5. werd geconstateerd blijkt ook hier weer dat de leeftija van patiënten, na correctie op de invloed wan vaardigheden van patienten, een aparte rol speelt bij het oordeel over verwangende zorg. De "improvement"-chikwadraat (G1-G2) was met een warde van 10.6. statistisch significant. Bij correctie voor de invloed van zowel leeftijd als socilale vaardigheden, draagt ook de houding van de patiënt zelf tegenover de afdeling en insteling apart bij aan het oordeel van hulpverleners (G3-G2). Het geconstateerde verband is negatief. Hoe positiever de patiënten zelf oordelen over hun afdeling en instelling, des te minder worden zij door hun hulpverleners aangemerkt voor vervangende zorg.

Tenslotte blijkt ook de diagnose schizofrenie, na correctie op sociale varardigheden. leeftijd en houding van de patiënt tegenover de afdeling en instelling, bij te aragen tot een minder positief oordeel over vervangende zorg.

In tabel 79 zijn de coëfficienten weergegeven voor de gestratificeerde variabelen. Daabij is gebruik gemakt van de volgende onderverdeling:

LITI: $75+=1, \quad 74-65=2, \quad 64-55=3, \quad 54-45=4, \quad 44-35=5, \quad 34-25=6,<25=7$; PSV: $0 \mathrm{t} / \mathrm{m} \quad 8$

SzF: niet $=1 ;$ wel $=2$

HA $:$ negatief $=1 ; 2,3 ;$ positief $=4$ 
Tabel 79: Resultaten van stap 4 van de logistische regressie.

\begin{tabular}{|c|c|c|c|c|}
\hline \multicolumn{2}{|l|}{ Variabele } & coëfficiënt & $\begin{array}{l}\text { standaard- } \\
\text { fout (s.e.) }\end{array}$ & coëff./s.e. \\
\hline Leeftijd & (LFT) & .326 & .108 & 3.01 \\
\hline pSV & & -.290 & .073 & -4.00 \\
\hline Schizofrenie & $(\mathrm{SZF})$ & -.299 & .153 & -1.95 \\
\hline Houding Afdeling & $(\mathrm{HA})$ & -.609 & .235 & -2.59 \\
\hline Constante (a) & & 1.15 & .971 & 1.18 \\
\hline \multicolumn{5}{|c|}{$y=\log \left(\frac{\mathrm{P}}{1-\mathrm{P}}\right)=1.15+.326 \mathrm{LFT}-.290 \mathrm{PSV}-.299 \mathrm{SZF}-.609 \mathrm{HA}$} \\
\hline
\end{tabular}

Driekwart (788) van de patiënten die door de hulpverleners voor vervangende zorg werden geindiceerd, en tweederde (638) van de patiënten die daarvoor niet in aanmerking kwamen, konden op de juiste manier worden ingedeeld met bovengenoemde vergelijking, bij een afkappunt $(y)$ van .692 . 
'? 
DEEL $V$ - CONCLUSIES, SAMENVATTIMG EN BESCHOUWINGEN

In dit proefschrift was de vraag aan de orde, warom bepalde patienten wel en andere weer niet voor vervangende zorg in aanmerking kwamen. De interesse ging vooral ult naar de onderliggende redenen en factoren voor dit verschijnsel, met als algemene vraag: welke aanwijsbare factoren belemmeren c $q$. bevorderen het ontslag naar vervangende zorg van lang opgenomen patienten uit psychiatrische ziekenhuizen?

Hoewel binnen de afhankelijke variabele, namelijk het oordeel over vervangende zorg, door de hulpverleners een breed spectrum van woorzieningen werd onderscheiden, werd bij de analyse alleen een onderscheid aangebracht tussen patiënten die wel $(\mathrm{N}=116)$ en patiënten die niet $(\mathrm{N}=265)$ in aanmerking kwamen voor vervangende gorg.

In dit verband werd voor een aantal (onafhankelijke) variabelen nagegaan, of zij op het tijdstip van onderzoek samenhingen met het oordeel van de hoofdbehandelaax en de verpleegkundige over de mogelijkheid van vervangende zorg. Bij enkele variabelen konden de resultaten van deze directe methode van toetsing (a) worden vergeleken met de ultkomsten van een meer indirecte toetsingsmanier. Hiertoe werden de lang opgenomen patiềten van psychiatrische ziekenhuizen op een aantal variabelen vergeleken met personen die na een langdurige psychiatrische opname inmidaels in beschermende woonvormen (toetsing b) of in psychiatrische dagbehandeling (toetsing o) verbleven.

War anleiding van gegevens uit het vooronderzoek in het P.M.s. Vijverdal te Mastricht was an de hand van een 19-tal hypothesen wan tevoren aangegeven, in welke richting een verband werd verondersteld tussen een aantal onafhankelijke variabelen en het oordeel van hulpverleners over vervangende zorg. De belangrijkste resultaten zullen hierna aan de hand van de volgende vragen worden besproken: Welke conclusies kunnen an de verkregen resultaten worden verbonden? In welke relatile staan de resultaten van de verschillende hypothesen tot elkar? In hoeverre zijn de resultaten in overeensteming of in tegenspraak met de ervaringen wit ander onderzoek? 


\subsection{Vaardigheden}

Aan de vardigheden van lang opgenomen patienten werd in ons onderzoek betrekkelijk weel aandacht besteed. Zo werden vier soorten vaardigheden onderscheiden, namelijk basale zelfredzaamheid, potentieel sociale varaigheden, interne en externe sociale integratie. Deze concepten bleken onderling samen te hangen. Als eerste voorwarde voor menselijke integriteit en onathankelijkheid was van belang dat betrokken patienten over elementaire lichamelijke en psychische vaardigheden beschikten zoals kleden, eten, lopen, slapen en zitten (zonder hulpmiddelen), continentie, orièntatievermogen en taalcompetentie (begrijpen en spreken van de Nederlandse taad). Dergelijke elementalre vaardigheden, warover de meeste 6-jarige kinderen beschikken, werden in dit onderzoek samengevat onder het begrip "basale zelfredzaamhejd" (BZR). De patiënten die op dit basale niveau ernstige tekortkomingen vertoonden, kwamen nauwelijks meer in aanmerking voor vervangende zorg. Het betrof veelal verpleegbehoeftige patienten, warvan aangenomen mag worden dat zij veel beslag leggen op de tijd van medisch geschoold personeel, zoals arts, verpleegkundige "fysiotherapeut e.d. Voor deze gehandicapte groep van patiënten zagen hulpverleners nalst het psychiatrisch ziekenhuis en eventueel het verpleeghuis nauwelijks meer mogelijkheden voor alternatieve opvang .

Bij 158 van de patiënten werden dergelijke ernstige beperkingen in de basale lichamelijke en psychische functies aangetroffen. voor de overgrote meexderheid (93\%) daarvan werd geen perspectief gezien voor plaatsing in vervangende zorg. Tot de groep patiënten met een geringe basale zelfredzaamheid behoorden vooral bejaarde patienten, patienten met de diagnose schizofrenie en organisch psychiatrische stoornis en zieke en lichamelijk gehandicapte patiẻnten. De meeste patiënten van deze groep waren reeds zeer lang opgenomen.

De patièten die in deze elementaire varaigheden ernstige gebreken vertoonden, hadden tevens grote tekorten in sociale vaardigheden en de mate van interne en externe sociale integratie. 
De Iichamelijke en psychische handicaps bleken in sterke mate gepaard te gaan met teruggetrokkemheid en isoliement op de afdeling (ISI). Meer dan de helft van de patiënten hielp nooit mee op de afdeling of elders in de instelling, was nooit buiten de therapie actief in de vorm van werken, lezen, spelletjes doen, hobbies of met anderen praten, en meer dan tweederde ging noolt met andere bewoners om en hielp nooit andere patienten ongevraagd bij wandelen, eten, spel e.d..

Wat echter vooral opviel, was de zeer geringe actieve deelname aan het matschappelijke leven buiten de insteling. Meer dan viervijfde van deze patiënten telefoneerde nooit, schreef geen brieven of karten, ging nooit midden in de week of in het weekend op bezoek bij kennissen, vrienden of familie, bezocht nooit een biascoop, theater, concert of kerk buiten het instellingsterrein, ging nooit boodschappen doen buiten het terrein en ondernam nooit andere activiteiten zonder personele begeleiding zoals wandelen, fietsen, zwemmen e.d..

Voor deze gehandicapte groep van patiënten lijkt dus de afdeling en het psychiatrisch ziekenhuis hun "wereld" geworden te zijn, een plaats waar men met alle beperkingen geaccepteerd en verzorga wordt.

a

Een redelijke of goede basale zelfredzaamheid bleek een noodzakelifke, echter geen voldoende voorwarde te zijn om voor vervangende zorg in aanmerking te komen. Dat mocht ook niet verwacht worden. Zo stelt een meer zelfstandig leven buiten de insteliling, max ook het begeleid samenwonen in kleinschalige voorzieningen op het terrein van het psychiatrisch ziekenhuis, hogere eisen an het varaigheids- en activiteitenniveau van patienten dan de genoemde basale aspecten van zelfredzaamheid. Het zichzelf kumnen. wassen, kleden, eten e.d. is in deze won- en leefsituaties niet meer voldoende. Andere vaardigheden, veelal met een hogere moeilijkheidsgraad, zijn daarvoor minstens even belangrijk. Om een meer onathankelijk leven te leiden zal men bijvoorbeela in stat moeten zijn om overdag zinvol met anderen te communiceren, men zal met geld moeten kunnen omgaan, kunmen telefoneren, van het 
openbaar vervoer gebruik kunnen maken, boodschappen doen en een eenvoudige maltijd kunnen bereiden.

Ongeveer de helft van de lang opgenomen patienten had ten aanzien van deze potentieel sociale vaardigheden (PSV) aanzienlijke beperkingen. Het bleek dat vooral deze sociale vaardigheden relevart waren voor de oordeelsvorming van de hulpverleners over mogelijkheden van vervangende zorg. Een duidelijk verschil met de BZR-score was dat een goede PSV-score tevens veelal overeenkwam met een positief oordeel over vervangende zorg. Zo werd 578 van de lang opgenomen patienten met goede sociale vaardigheden (PSV) geschlkt geacht voor ontslag of overplaatsing naar een andere voorziening .

In het onderzoek waren de sociale vardigheids-vragen zo geformuleerd en toegelicht dat zij de competentie, de mogelijkheden van de betrokken patiënt, meten. Indien in het onderzoek van het vertoonde gedrag was uitgegaan, dan was niet alleen een schatting verkregen van de competentie, maar tevens zou de invloed zijn gemeten van ongevingsfactoren, zoals de openheid van de instelling, de geografische ligging van het ziekenhuis ten opzicht van woonkernen, winkels e.d., maar ook de bereikbaarheld door openbaar vervoer, het aanwezig zijn van een telefoontoestel op de afdeling, en de omvang en aard van de rehabilitatieprogramma"s voor lang opgenomen patienten. Daarnaast is het mogelijk dat patienten wel over de genoemde sociale varardigheden beschilken, mar ten gevolge van een rechterlijke machtiging, suicidepoging. agressief gedrag of exnstig arankmisbruik de vaardigheden niet in de praktijk mogen toepassen.

Bij de interne en externe sociale integratile ging het om het vertoonde gedrag, hamelijk de mate van coöperatief gedrag en sodiale aanpassing binnen de instelling enerzijds en de contactfrequentie en -intensiteit met het matschappelijke leven buiten de instelling anderzijas.

Deze twee vormen van sociale integratie konden nauwelijks onafhankelijk van elkaar worden waargenomen. De onderlinge correlatie van de twee concepten was hoog $(r=66)$. Patiènten die weinig deelnamen aan het sociale gebeuren binnen de instelling, hadden 
In de regel ook weinig contact met de wereld buiten het terrein van het psychiatrisch ziekenhuis. Deze relatie werd ook in positleve zin gevonden: patiënten met een grote mate van interne sociale integratie hadden ook betrekkelijk veel interesse voor en contacten met het matschappelijke gebeuren bulten het ziekenhuis.

Belde groepen patienten, namelijk personen met goede ISI-scores en personen met goede ESI-scores, waren dan ook betrekkelijk homageen van samenstelling, wat betreft een aantal kenmerken. Voor het merendeel waren zij jonger aan 55 jaar, niet gehuwd, vertoonden nauwelijks agressief gedrag, hadden minder vaak de diagnose schizofrenie of organisch psychiatrische stoornis en vaker de diagnose neurose, depressie of persoonlijkheidsstoornis, en waren minder lang opgenomen dan patiënten met een geringe ISI of ESI.

De conclusie van Schudel (1976) dat schizofrene patiënten minder contact hebben met de buitenwereld, werd in dit onderzoek nogmaals bevestigd. Tevens hadden schizofrene patiënten aanzienlijk minder contact met medepatiënten en het personeel van de afde1 ing.

Maar er waren ook verschillen tussen patiënten met een goede ISI en patiënten met een goede ESI. zo bestond de groep patiënten met een goede externe sociale integratie vaker uit mannen, terwijl in de groep patiënten met een goede ISI meer vrouwen voorkwamen. Segal en Everett-Dille (1980) kwamen in hun onderzoek naar de socilale integratie van patienten tot soortgelijke bevindingen, maar dan voor mannen en vrouwen van beschermende woonvormen. De groep patiënten met een goede ESI was tevens, in vergelljking met patiënten met een goede IST, gemiddeld jonger, had (daarom) meer levende ouders en broers en zusters, was minder lang opgenomen, en beschikte over een betere zelfredzamheid en over potentiel sociale vaardigheden.

Tussen de onderscheiden varardigheden bestond een zekere hiërarchie. Patiënten met goede ISI- of ESI-vaardigheden hadden tevens goede $B Z R$ - of redelijke tot goede potentieel sociale vararaigheden. Tevens bleek iedere vaardigheidsvariabele apart bij te 
dragen tot en positief oordeel over vervangende zorg. zo hadden patienten die alleen zelfredzaam waren, minder kans op een positieve indicatiesteling dan patiënten die zelfredzaam en tevens sociaal vaaraig waren. De patiênten tenslotte met een optimaal vaardigheidspatroon (BZR ${ }^{+} \mathrm{PSV}^{+} \& \mathrm{ISI}^{+}$\&SI $\mathrm{ES}^{+}$) hadden met 64 ook de beste kansen om door de hulpverleners voor vervangende zorg te worden ingedeeld. Eén op de zeven patiënten van de steekproef vertoonde zo'n optimal patroon.

Het gebrekigenmodel (Giel, 1982; siegler osmond, 1976) blijkt dus niet voor alle lang opgenomen patienten van toepassing te zijn. In de algemene psychiatrische ziekenhuizen had 15 van de lang opgenomen patiënten nauwelijks beperkingen op de door ons bestudeerde varalgheden om zelfstandig buiten de instelling te leven, en had op de afdeling en daarbuiten aangetoond met andere mengen om te kunnen gaan zonder dat daarbij veel professionele begelelding noodzakelijk was.

Bij een goede deelname van patiënten aan activiteiten binnen (ISI) en buiter de instelling (ESI) werd dit ongeacht het functioneren op de overige vaardigheden (BZR, PSV) positief beoorderld in verband met mogelijkheden voor vervangende zorg. Zowel patiënten met beperkte sociale vaardigheden als patiënten met een beperkte zelfredzaamheid (BZR) kwamen nog voor meer dan éénderde daarvoor in aanmerking indien zij goed participeerden op de afdeling (ISI) of veelvuldig contact hadden met de wereld buiten de instelling (ESI). Niet alleen de ard van de wardigheden. zoals BZR of PSV, en de mate warin men deze vardigheden heeft. is dus bepalend voor het oordeel over vervangende zorg, maar ook de manier, warop de patiënt heeft geleerd met gebrekkige vaardigheden te leven en gemotiveerd is (of wordt) om van deze beperkte vaardigheden gebruik te maken in het contact met anderen binnen of buiten de instelling. 


\subsection{Structuur en houding van het thuismiliev}

Wanuit het oorspronkelijke thuismilieu bleken na een langdurige opname weinig stimuli uit te gaan voor het aanbieden van vervangende zorg. Enkele patiënten (4\%) hadden geheel geen familieleden meer, en velen beschikten over een beperkt thuismilieu.

Bilj de lang opgenomen patienten kwamen een drietal thuismilieusituaties veel voor;

- 37 g van de patiënten had geen levende ouders meer, mar wel tenminste één broer of zuster; betrokkenen hadden geen huwelijkspartmer en ook geen kinderen.

- 32 van de patiênten had nog tenminste één levende ouder en broer of zuster, mar was niet gehuwd en had ook geen kinderen. terwijl

- 11 van de patiënten geen levende ouders had, maar wel levende broers of zusters; ze waren niet (meer) gehuwd, maar hadden wel tenminste één kind.

Voor een deel is de beperkte anwezigheid van levende familieleden te verklaren door een ongunstige (ongehuwd blijven) en kwetsbare positie (scheiding) op de huwelijksmarkt van patienten met langdurige psychiatrische problemen, zoals bleek bil nieuwe langblijvers (Giel, 1978; Haveman, 1980c) en frequent opgenomen patienten (Haveman, 1980a\&b; Brook, 1984). Minstens even belangrijk is echter de gevorderde leeftijd van de patiënten. Meer dan twee derde van de lang opgenomen patienten was 50 jaar of ouder en ongehuwd. Veelal waren de ouders van deze patiènten overleden, en bestond het primalre milieu alleen uit broers en/of zusters van ongeveer dezelfde leeftija. De rogelijkheid tot inwoning bij en begeleiding door familieleden is dus voor deze patiénten zeer beperkt aanwezig. Deze grote groep van patiënten kan veelal niet meer terugvallen op een intact thuismilieu, en is bij eventueel ontslag afhankelijk van vervangende huisvesting en zorg, - in welke vorm dan ook. Na correctie op de invloed van leeftijd bleek het overigens weinig uit te maken voor het oordeel van hulpverleners over vervangende zorg, of patienten wel of niet veel familieleden 
hadden. Tevens werden gean verschillen gevonden in het vervangende zorgoordeel bij patiënten met familieleden die positief, ambivalent of negatief atonden tegenover een eventueel ontslag.

\subsection{Psychiatrische diagnose}

Bij de rehabilitatie van lang opgenomen patiënten wordt rinder uitgegaan van het zgn. medische model, waarbij aspecten als giekte, symptomen, etiologie, beloop, prognose en medische interventie voorop staan. Men zou kunnen stellen dat de periode war het medische model relevant was voor de patiënt en hulpverlener is afgesloten. De diagnose werd reeds enkele jaren geleden gestela en verschillende therapeuten hebben met verschillende technieken vele jaren hun kernis en ervaring toegepast, - maar helaas voor deze groep patiënten met wisgelend of gering succes.

De uiteindelijke doelstelling van psychiatrische diagnosestelling is in de loop van de jaren vervaagd en heeft nawwelijks meer een doelgexichte betekenis voor de verdere zorg en begeleiding van betrokkene. De bedoelingen die Giel (1982) toekent an het proces van psychiatrische classificatie zoals:

"1. het opsporen van kenmerken van mensen en hun gedragingen die het vinden van de oorzaak van hun stoornis kunnen vergemakke1i.jken:

2. het voorspellen van de meest warschijnlijke afloop van de stoornis;

3. het kiezen van een interventie en het voorspellen van het mogelijke effect darvan op de afloop van de stoornis", lijken voor de verbetering van de leefsituatie van lang opgenomen patiënten niet meex functioneel te zijn. De diagnose is gesteld, de afloop van de stoornis is grotendeels bekend, en de effecten van de interventies zijn geëvalueerd.

De beperkte toepasbarheid vam het medische model voor de zorg voor lang opgenomen patièten betekende echter niet dat alle patiënten - ongeacht de gestelde diagnose - dezelfide kans hadden op vervangende zorg. 
zo werden schizofrene patienten in vergelijking met de overige patienten beduidend minder vaak voor vervangende zorg ingedeela. Tevens bleken minder schizofxene patienten in beschermende woonvormen on psychiatrische dagbehandeling te verblijwen dan mer. gezien hum aandeel (508) in psychiatrische ziekenhuizen zou mogen verwachten. Voaral voor de groep van schizofrene patienten is het dus mogelijk dat hulpverleners in verband met symptomen, bizar en onvoorspelbaar gedrag en dergelijke, eerder een negatieve indicatie stellen voor vervangende zorg.

\subsection{SuIcidaal, agressief gedrag en onvrijwillig verblijf}

SuIcides komen aanzienlijk meer voor bij recent opgenomen patiennten dan bij patiënten die langdurig in psychiatrische ziekenhuizen verblijven. In een Deens landelijk registeronderzoek naar het aantal suicides bij opgenomen patiënten over de periode 1971 tot 1981 (Barner-Rasmussen, 1986) bleek dat vooral in de eerste maand na de opname het grootste suiciderisico bestond. van de 863 patiênten die in deze periode door middel van sulcide waren overleden gebeurde dit blj 44 o van de patiënten binnen twee weken na de opname, en was 60 in het verloop van een maand owerleden. Met de toename van de verblijfsduur en de leeftijd nam het risico van een suicicide af.

In ons onderzoek ging het niet om sulicides, maar om sulcidedreigingen en -neigingen bij lang opgenomen patiënten. Daarbij bleek dat ook sǚcidaal gedrag betrekkelijk zelden voorkomt bij lang opgenomen patienten. In de periode van drie manden vóbr het onderzoek was door 48 van de patienten gedreigd met wuicide of was daadwerkelijk een poging daartoe ondernomen. Tegen onze verwachting in kwamen deze patiënten volgens hun hulpverleners niet minder, maar zelfs iets meer in aammerking voor vervangende zorg. Indien de agressie niet op de eigen persoon was gericht. mar op anderen, en ernstiger vormen aannam, dan hadden deze patiënten ook mindex kans op vervangende zorg. 


\subsection{Leeftijd}

Bij de indicatiestelling voor vervangende zorg speelde de leeftija van patiénten een belangrijke rol. Ook als de oudere patienten $\left(55^{+}\right)$nilet verschilden van hur jongere lotgenoten, wat betreft de vardigheden (BZR, PSV, ISI en ESI), de diagnose, agressief of sulcidal gedrag en de verblijfsdur, dan nog hadden owdere patienten een aanzienlijk kleinere kans om in aammerking te komen vook alternatieve opvang. Het lijkt dus, alsof bij jongere en oudere patienten met twee verschiliende maten wordt gemeten.

Het waren vooral de ondere patienten met de diagnose schizofrenie, die welnig kans makten op verwangende zorg. Zo kwamen de bejaarde pationten met een andere diagnose dan schizofrenie met. $25 \%$ aanzienlijk meer daarvoor in aanmerking. Wel waren deze patiënten ook gezien de vaaraigheden minder gehandicapt dan bejaarde schizofrene patiënten (tabel 80 ).

Tabel 80: Typering van een viertal groepen aan de hand van het aandeel patiènten met goede vaardigheden (BZR, PSV, ISI, ESI) en met een positieve indicatie voor vervangende zorg.

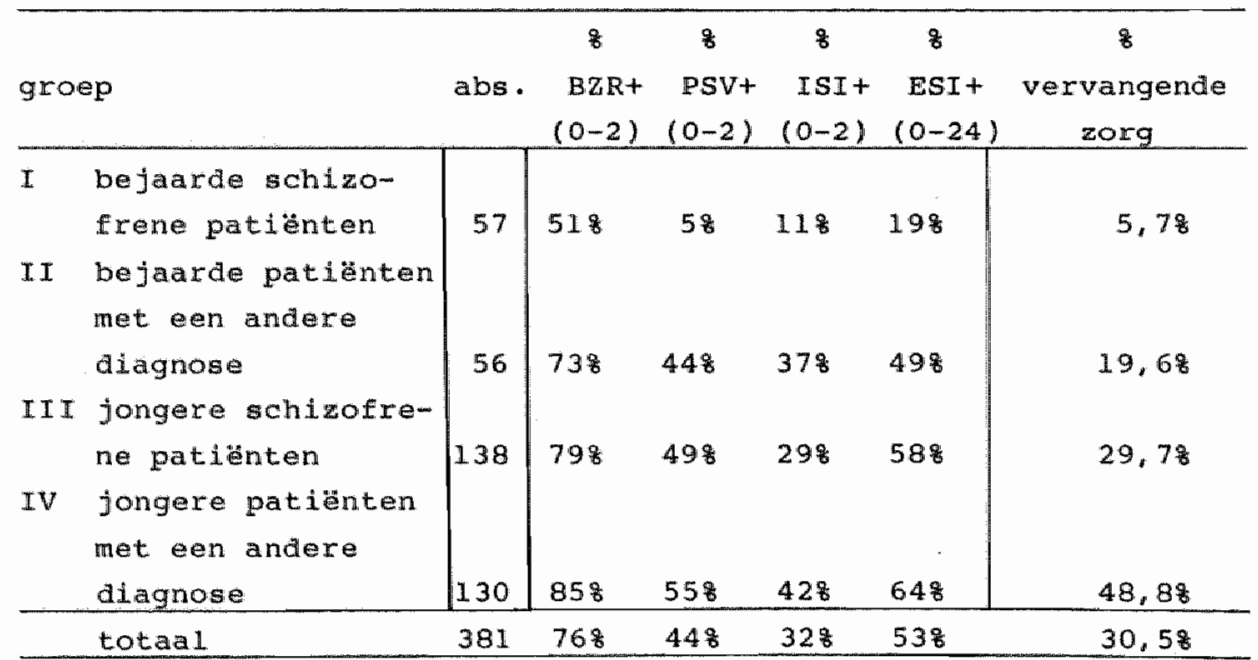


Groep I (15\%): met de groep van bejaarde schizofrene patientien kan een betrekkelijk vaste kern van piersonen worden aangewezen waarvoor nauwelijks meer perspectief bestaat voor vervangende zorg. Alleen voor enkele goed zelfredzame en soclaal vaardige personen van deze groep werden nog mogelijkheden gezien voor plaatsing elders. De helft van de groep bejaarde schizofrene patiënten was beperkt zelfredzaam, en bijna ledereen (958) vertoonde tekorten in de (potentiëel) sociale vaardigheden. Voor de meeste patiënten was de integratie in het leven zowel binnen de instelling $(898)$ als daarbuiten ( 818 ) matig tot gering. Er zijn aanwijzingen dat ook in landen, waar een meer rigoreus ontslagbeleid is gevoerd ten aanzien van lang opgenomen patiönten, zoals in de Verenigde staten, het vooral de oudere schizofreme patiënten zijn die in paychiatrische ziekenhuizen opgenomen blijven. Goodman en siegel (1986) merken naax aanleiding van hun follow-up onderzoek van bejaarde schizofrene patienten op dat " ... more than $70 \%$ of all the patients in our study who had been hospitalized for more than 1 year before the study began remained in the hospital at the end of the 4-year follow-up. Despite their hospitalization in an era of deinstitutionalization, these elderIy patients will probably remain in the state hospital until death".

Groep II (15\%): de groep bejaarde patiênten met een andere diagnose was evengroot van omvang als de groep bejaarde schizofrene patiënten. Ondanks een vergelijkbare leeftijj waren de patiënten aanzienlijk minder gehandicapt in hun zelfredzaamheid en sociale vaardigheden, en participeerden voor een deel goed in het gemeenschapsleven binnen en buiten de instelifing. ongeveer 20 van deze groep bejaarden kwam dan ook nog in anmerking voor vervangende zorg.

Groep III (368): met meer dan éenderde van de steekproef vormden de schizofrene patienten met een leeftijd variërend van 20 tot 64 jaar de grootste groep binnen het onderzoek. Viervijfae van deze patiënten was goed zelfredzaam, en de helft had tevens goede (potentiẻel) sociale vaardigheden. Hun deelname aan activiteiten binnen de instelling was beperkter (298) in vergelijking met de 
bejaarde patiënten van groep II. Daarentegen hadden zij wel meer contact met het matschappelijke gebeuren butten de ingteling (588). Voor ongeveer dertig procent van deze patiënten was volgens het gezamenlijke oordeel van de hoofdbehandelaar en verpleegkunalge alternatieve opvang mogelijk.

Groep IV (34): de patiëten van 20 tot 64 jaar met een andere diagnose dan schizofrenie hadden van de onderscheiden groepen (tabel 80) het beste perspectief op vervangende zorg. Bijna de helft (498) van deze patiënten kwam volgens hun hulpverleners in aamerking voox vervangende zorg. De zelfredzaamheid van deze patienten was in het algemeen goed ( $85 \%$ ) en meer dan de helft was sociaal vaardig. zij functioneerden duidelijk beter, wat betreft de mate van interne sociale integratie, dan de niet-bejaarde schizofrene patiënten. Tevens had bijna tweederde van de patienten van groep IV regelmatig contact met het matschappelijke leven buiten het terrein van de instelling.

\subsection{De houding van patiënten ten aanzien van ontslag en de afdeling}

Voor de vraag welke patiênten wel en welke patiënten niet voor vervangende zorg in aanmerking kunnen komen, bleek dus vooral de combinatie van vaardigheden, leeftijd en diagnose van belang te zijn. Tevens was duidelijk dat enkele agressieve patienten volgens hun hulpverleners niet voor vervangende zorg in aanmerking mogen komen, omdat dergelijk gedrag buiten het psychiatrisch ziekenhulis niet te hanteren is.

Maar hoe stonden de lang opgenomen patiẻnten zelf tegenover de mogelijkheid van ontslag en en leven buiten het terrein van het poychiatrisch ziekenhuls? Is het wel hun wens, - willen zij eigenlijk wel in anmerking komen voor andere huisvesting en een meer zelfstandige leefsituatie?

We vonden dat ongeveer éénderde van de patiënten een positileve houding innam ten aanzien van ontsiag. Bijma evenveel patiënten waren ambivalent, terwijl éénkwart van de patiénten uitgesproken negatief reageerde op vragen over een mogelijk verblijf bulten de 
instelling " Het was enigsins verrassend dat er nawwelijks verschillen bestonden in ontslaghouding tussen patienten die korter dan twee jaar verbleven, dan wel twee tot wijf jaar, of zes tot tien jaar.

Met een opnameduur van ongeveer tilen faar veranderde dit beeld. Zo hadden aanzienlijk meer patiënten (408) die langer dan 10 jaar waren opgenomen, de uitgesproken wens niet van verblijfplaats te veranderen, $34 \%$ van de patiënten was in zijn houding ambivalent, en ongeveer één kwart van de patiënten (27\%) had nog de wens met ontslag te gaan.

Het waren wederom de patiënten met een opnameduur wan tien jaar of langer die erg gehecht waren aan de leefsituatie op de afdeling. En dit verschijnsel bleef niet beperkt tot de oudere patienten. Ook bij de patiënten die jonger dan 55 jaar waren, werd een verband gevonden tussen de verblijfsduur en de houding ten aanzien van ontsiag: hoe langer men was opgenomen, des te negatiever was de ontslaghouding.

Deze relatie tussen verblijfsdur en houding ten aanzien van ontslag, die wing (1962) reeds vijfentwintig jaar geleden constateerde, werd dus in ons onderzoek ook voor de Nederlandse situatie en voor een meer recent jaar bevestigd. Barton (1976) onderkende hetzelfde fenomeen, mar dan op basis van klinische ervaringen. Hij wees erop dat het met een toenemende verblijfsduur steeds moeilijker wordt om opgenomen patiënten ervan te overtuigen dat de moeilijke stap naar buiten nog steeds de moeite waard is. Hij schrijft: "It is difficult to persuade patients that the tremendous effort to re-enter the world outside is worth the gain. Many patients say they never wish to leave hospital: "I'm quite happy jogging along here, Doctor" or "Leave me alone, Doctor, I'm not well enough to manage outside", or "Nobody wants me - they haven"t got room".

Deze relatie tussen verbliffsduur en ontslaghouding werd gevonden voor de diverse groepen patiënten: mannen en vrouwen, jongeren en ouderen, gehuwden en alleenstaanden, schizofrene patienten en patiënten met andere diagnosen, patiënten met en zonder 1ichamelijke handicaps, patiënten met goede en minder goede potentiẻel 
sociale vardigheden, interne en externe sociale integratie. Tevens werd de relatie gevondem bij patiënten met en zonder agresilef gedrag en patienten met eer betrekkelijk volledig of onvolledig thuismilieu. Wel bleek een uitzondering te bestarn voor patiënten met ernatige beperkingen in de basale zelfredzaamheid en patiënten met suicideproblemen.

Er zijn dus aanwijzingen dat ae verblljfsduur van patienten niet alleen een indicatie is van de ernst en de duur van de stoormis, mar tevens iets zegt over de vookkeur van de patiënt om in de instelling te blijven wonem. Drake en Wallach (1979) en Adler e.a. (1984) hebben reeds eerder op dit fenomeen gewezen. Een langere verblijfsduur ging overigens niet alleen gepaard met een meer negatieve instelling van patiënten ten aanzien van ontslag, maar tevens met een positieve houding tegenover de eigen afdeling en instelling. Ook deze relatie was wederom gellig voor de verschillende subgroepen, met uitzondering van gehuwde patienten, patiënten met een betrekkelijk volledig thuismilieu en patiënten zonder enig agressief gedrag.

Vooral de patienten die korter dan vijf jaar waren opgenomen, namelijk 61\%, hadden een ambivalente houding ten aanzien van de afdeling en instelling. Met de duux van het verblijf veranderden deze twijfels steeds meer in een aanvaardende, positieve attitude.

Terwijl van de patienten die korter dan 5 jaar waren opgenomen, éenkwart positief scoorde op de Houding Afdeling (H.A.)-index, nam dit aandeel met de verblijfsduur steeds meer toe. Een uitgesproken negatieve houding ten aanzien van de afdeling en instelling kwam met 11 s van de steekproef patienten betrekkelijk weinlg yoor, en dit aandeel was constant ongeacht de duur van het verblijf *

Voor de gevonden relatie tusaen verblijfsduur en houding ten aanien van de afdeling/insteling zijn verschillende verklaringen mogelijk. Enkele daarvan zijn echter gezien onze bevindingen minder warschijniljk. 
- Een eerste tentatieve verklaring, namelijk dat patienten die zeex lang zijn opgenomen, misschien lichamelijk meer kwetsbar zijn en daardoor de huisvesting, de begelelding en de contacten met patiènten en hulpwerleners gunstiger ervaren, is niet erg aannemelijk. Zo was de houding van lichamelijk gehandicapte patiënten en patiẻnten met een geringe basale zelfredzaamheld ten aanzien van de afdeling/instelling minder positief dan de houding van njet gehandicapte en zelfredzame patiënten. Ook de zeer lang opgenomen patienten die lichamelijk kwetsbaar waren. hadden een minder positieve houding tegenover de afdeling en instelling.

- ook een andere mogelijke verklaring, namelijk dat zeer lang opgenomen patienten door hun veelal oudere leeftijd misschien gexingere verwachtingen hebben, minder eisen stellen en minder critisch zijn ten aanzien van de leefsituatie op de afdeling dan jongere patiënten, werd niet gesteund door de onderzoeksxesultaten. Tot en met een verblijfsduur van 20 jaar verschilden patiënten van 55 jaar en ouder en patiënten die jonger dan 55 jaar waren, nauwelijks van elkaar, wat betreft hum houding tegenover de afdeling. Bij de groep patienten met een verblijfsduur van langer dan 20 jaar bleek zelfs dat jongere patienten. met een aandeel van 67\%, aanzienlijk positiever waren dan de oudere patiënten (55\%).

- Tevens is het niet waarschijnlijk dat de positieve houding van zeer lang opgenomen patienten ten aanzien van de afdeling vooral te verklaren is door eenzijdige gerichtheld op activitellten binnen de insteling. Het waren niet de patienten met een minder goede externe sociale integratie (ESI) die hoog scoorden op de Houding Afdeling-index, mar vooral de patiênter met een goede externe sociale integratie. Van de patienten die 6 tot 20 jaar in de instelling verbieven en een goede EsI-sicore hadden, vertoonde 51 een positieve houding ten aanzien van de afdeling. Bij de patienten die langer dan 20 jaar waren opgenomen, was dit aandeel zelfs $71 \%$. 
- Aan de hand van de gegevens was het mogelijk on na te gaan of zeer lang opgenomen patienten misschien mincer overtuiga zijn van de halbaarheld of wenselijkheid wan een verblijf buiten het instituut en misschien daarom het verblijf in het psychiatrisch ziekenhuis extra warderen. Deze relatie kon gedeeltelijk worden bevestigd. De grote groep van zeer lang opgenomen patienten ( 25 jaar) bestond vooral uit personen die een negatieve of ambivallente houding innamen tegenover een eventueel ontslag. Van deze patiënten met weerstanden en reserves tegenover ontslag oordeelde 628 positief over de afdeling. Bij de kleinere groep van patiënten die twee tot vijf jaar in de instelling verbleef en een ambivalente of negatieve ontslaghouding vertoonde, was daarentegen alleen $37 \%$ positief over de afdeling .

$\mathbb{E}$ n dan blijven nog een aantal verklaringen over die even goed van toepassing kunnen zijn, maar waarover geen empirische gegevens werden verkregen.

- Het is mogelijk dat kort opgenomen patiënten de leefsituatie binnen het psychiatrisch ziekenhuis toetsen aan de woonsituatie, de privacy en de autonomile die zij eventueel hadden, voordat de opname plaatsvond. Dit referentiekader is echter voor zeer lang opgenomen patiênten steeds meer vervaagd en is vervangen door de woonsituatie en de huisregels van het psychiatrisch ziekenhuis. Het zou een plausibele verklaring kunnen $z i j n$ voor het fenomeen dat met toenemende verblijfsduur meer patiënten een positieve houding innemen ten aanzien van de leefsituatie op de afdeling. Onder andere Mechanic (1980) heeft erop gewezen dat het referentiekader, waarvanult ook recent opgenomen pationten oordelen over de zorg, de woonsituatie en andere levensomstandigheden in het psychiatrisch ziekenhuis verschilt met het oordeel van personen die buiten het psychiatrisch ziekenhuis wonen. Het verblijf in een psychiatrisch ziekenhuls is, volgens Mechanic, voor veel patienten een laatste toevluchtsoora, - een asyl in positieve zin, toen zij niet meer opgewassen waren tegen de moeilijke situaties, warin zij buiten de ingtelling verkeerden. Gezien deze ervaringen zou het 
niet verbazingwekkend $z i j n$ dat patiënten weinig aandacht schenken aan beperkende maatregelen in het $z$ Hekenhuis, en dat zij de ontvangen zorg en andacht binnen de instelling in het algemeen positief warderen. Soortgelijke kanttekeningen werden reeds eerder geplaatst door Mayer en Rosenblatt (1974) naar aanleiding van onderzoek naar de houding van 200 personeelsleden en 220 patiënten ten aanzien van de leefsituatie op de afdeling. zij concludeerden dat het personeel minder gunstig oordeelde over de leefsituatie dan patiënten. De hulpverleners waren vooral positief te spreken over de bijeenkomsten in kleinere groepen waar patienten over hun problemen konden praten. De patiènten daarentegen hadaen een meer positieve houding ten aanzien van maaltijden, het netjes houden van kamers, de veiligheid op de afdeling, de vrije tijd-activiteiten en de beschikbaarheid van de arts.

- Het is ook mogelijk dat zelfselectie heeft platsgevonden op basis van de houding ten aanzien van de afdeling. Hiermee wordt bedoeld dat patiënten die het verblijf in het psychiatrisch ziekenhuis als te beperkend ervaren en het ziekenhuis niet als langdurig woonmilieu accepteren, eerder geneigd zullen zijn buiten het psychiatrisch ziekenhuls naar een alternatieve opvangmogelijkheid te zoeken, vergeleken mèt patiënten die reeds na een betrekkelijk korte opnameduur zich binnen de instelling thuis zijn gaan voelen. In een dergelijke redenering zijn het vooral de patiënten die van begin af aan een positieve houding innemen tegenover de afdeling, die zeer langaurig in het psychiatrisch ziekenhuis zullen verblijven.

- En tenslotte is het mogelijk dat zeer lang opgenomen patienten vooral op afdelingen verblifven, waarbij wordt uitgegaan van min of meer definitieve huisvesting en zorg, terwiji minder lang opgenomen patiënten veelal nog op afdelingen verblijven met een rehabilitatie-functie. Ook dergelijke verschilien in zorgintenties op afdelingsniveau kunnen eventueel tot uiting komen in de houding van patiënten ten aanzien van de afdeling. maar tevens in de houding ten aanzien van ontslag (hfdst. 12.11$.$) .$ 
De duur van het verblijf in het psychiatrisch ziekenhuls was niet alleen var belang voor het pordeel van de patiemt over de leefsituatie op de afdeling en de houding ten aanzien van ontsiag, mar hing tevens samen met het oordeel van de hulpverleners. Maarmate patienten langer in het psychiatrisch ziekenhuis verblewen, kwamen zij volgens hun hulpverleners minder in aanmerking woor vervangende zorg.

De meeste patiẻnten van onze steekproef verbleven op afdelingen, war weinig doorstroming platavond. Zo verbleef ongeveer drie kwart op afdelingen. waar meer dan 708 van de medepatienten langer dan één jaar was opgenomen. De overige steekproefpatienten verbleven op afdelingen met een grotere doorstroming. En het waren vooral de patienten van deze afdelingen die met $53 \%$ eerder in aanmerking kwamen voor vervangende zorg. Ook na controle op de mogelijke invloed van variabelen als de leeftijd, de verblijfsduur en de potentiêel sociale varaigheden, werden de patiënten van afdelingen met een grotere doorstroming eerder voor vervangende zorg ingedeeld dan patiénten van afdelingen met een geringe doorstroming.

Er zijn dus aanwijzingen dat hulpverleners van afdelingen, waar meer patiënten ontslagen worden, eerder geneigd zijn lang opgenomen patiënten voor vervangende zorg in te delen dan hulpverleners van afdelingen met betrekkelijk weinig doorstroming. Meer ervaring en betere contacten met bijvoorbeeld beschermende woonvormen, psychiatrische dagbehandeling en Riagg's kunnen daarbij een rol spelen.

De doorstroming op de afdeling is echter geenszins de belangrijkste factor bij het oordeel van hulpverleners. Indien simultaan de invloed vam een negental factoren, waronder de doostroming op de afdeling, wordt bestudeerd dan zijn vooral de leeftijd, de potentiëel sociale varalgheden, de diagnose schizofrenie en de houding van de patient tegenover de afdeling en instelling bepalend voor het oordeel van de hoofdbehandelaar en verpleegkundige welke patient wel en welke niet in aanmerking komt voor vervangende zorg. 
VOETNOTEN

(1) In de periode van het onderzoek is een advies van de ziekenfondsraad (1984) verschenen met onder andere een ontwerpbesluit psychiatrische deeltijdbehandeling ziekenfondswerzekering. In dit ontwerpbesluit ontbreekt het indicatiecriterium "verwachting van het verkrijgen van een volledige zelfstandigheid". Wel wordt aangekondigd dat dit criterium nader zal worden uitgewerkt bij Koninklijk Besluit.

(2) Het begrip "pane1-onderzoek" zal in dit verband niet worden gebruikt. In de sociale wetenschappen is dit begrip gereserveerd voor een ander type onderzoek (Nehnevasja, 1973;

Swanborn, 1981).

(3) - Bij flat-/huisbewoning met begeleiding vanuit Riagg of polikliniek hadden patiënten warbij beperkte overeenstemming bestond tussen psychiater en verpleegkundige eerder de diagnose schizofrenie en persoonlijkheidsstoornis (p<.05);

- bij beschermende woonvormen buiten het ziekenhuisterrein hadden de patiënten warbij beperkte overeenstemming bestond in het algemeen slechtere scores op interne socilale integratie.

(4) Bij een apart overzicht voor het jaar 1983 (met selectie op verblijfsduur langer dan twee jaar en diagnose anders dan dementie en zwakzinnigheid) kon een leeftijasgemidaelde van 57 jaar worden berekend en een standaardafwijking van 17.

(5) $\mathrm{N}_{\mathrm{t}}=\frac{t}{\mathrm{~T}} \times \mathrm{N}_{\mathrm{T}}\left(\mathrm{N}_{\mathrm{t}}=\frac{120}{23} \times 190=990\right)$

Waarbij:

$\mathrm{N}_{t}=$ totaal aantal doelgroeppatiënten in dagziekenhuizen

$\mathbb{N}_{\mathrm{T}}=$ aantal steekproefpatienten in dagziekenhuizen

$t=$ totaal aantal erkende dagziekenhuizen

$\mathrm{T}$ = aantal deelnemende dagziekenhuizen. 
(6) De aandulding van deze categorie van voorzieningen is bewust niet vertald, daax de Nederlandse "psychogeriatrische verpleeghuizen" een aanzienlijk nauwer indicatiegebied kennen, namelijk poral verpleegbehoeftige demente bejaarden * 


\section{LITERATUURVERW IJZ INGEN}

Achte $K$, steinbäck A (1966), Chronic psychiatric hospltal patients, Acta Psychiat Scandinavica 42, 341-347.

Adler DA, Drake RE, Stern $R(1984)$, Viewing chronic mental illness: a conceptual framework, Comprehensive Psychiatry, Vol. 25, no. 2, 192-207.

Armstrong B (1979), The community lodge: helping the chronically mentally 111 help each other, Hospital \& Comm Psychiatr 30 , no. $10,705-708$.

Baas M, Cornelissen E, Frohn-de Winter M, Bleeker J (1984), Het gebruik van de BOP in een psychiatrische klimiek. Een praktijkonderzoek. T Gerontologie en Geriatrie, 15, 197-201. Babiker IE (1980), Social and clinical correlates of the "new" long stay. Acta Psychiat Scand 61, 365-375.

Bachrach L (1976), Deinstitutionalization: An analytical review and sociological perspective, DHEW publ. no. (ADM) 79-3531, Rockvilile, Ind., NIMH.

Barner-Rasmussen $\mathbf{P}$ (1986), Suicide in psychiatric patients in Denmark, 1971-1981. II. Hospital utilization and risk groups, Acta Psychiat Scand 73, 449-455.

Barton R (1976), Institutional Neurosis, Chicago, Year Book Mecical, John Wright \& Sons.

Bennett $\mathrm{DH}$ (1983), The historical development of rehabilitation services, in (Watts FN \& Bennett $\mathrm{DH}$ ). Theory and practice of psychiatric rehabilitation, John Willey sons, Ltd.

Blalock HM (1960), Social statistics, McGraw-Hill.

Brady JP (1984), Social skills training for psychiatric patients, I: concepts, methods and clinical results, Am J Psychiatry $141,3,333-340$.

Braun $P$, Kochansky $G$, Shapiro $G$, Greenberg $S$, Gudeman $J$, Johnson S, Shore M (1981), Overview: Deinstitutionalization of psychiatric patients, a critical review of outcome studies, Arm I Psychiatry 138, 6, 736-749.

Brook OH (1984), Heropnemingen in de algemene psychiatrische ziekenhuizen, T Psychiatrie 26, 7, 500-525. 
Brorsson B, Wall $s$ (1985). Assessment of medical technology, Swedish Medical Research Council, MER.

Brown G, Carstairs G, Topping G (1958), Posthospital adjustment of chronic mental patients, The Lancet, 2 , 89, 685-589.

Brown G (1960), Length of hospital stay and schizophrenia: a review of statistical studies, Acta Psychiat Neurol Scand 35. $414-430$.

Chien CP, Sharaf MR (1971), Fetors in the discharge of chronic patients, Hosp \& Comm Psychiatry, Vol 22, no. 8, 334-339.

Cohen $J(1960)$. A coefficient of agreement for nominal scales, Educ Psychol Measurement, Vol XX, No. 1, 37-46. Creere C, Wykes $\mathrm{T}$ (1982), The role of relatives, in (JK Wing) Jong-term community care, Psychological Medicine Monograph Supplement 2 .

Christie Brown JR, Ebinger L, Treedman LS (1977). A survey of a long-stay psychiatric population: implications for community services, Psychol Med 7, 113-126.

Ciompi L (1980), Ist die chronische Schizophrenie ein Artefakt? Argumente und Gegenargumente, Fortschr Neurol Psychiatrie, $28, \quad 237-248$.

Cronbach L, Ideka H, Arner R (1964), Intraclass correlation as an approximation to the coefficient of generalizability, Psychol Reports, 15, 727-736.

Definitief regeringsstandpunt ten aanzien van de beschermende woonvormen voor (ex-) psychiatrische patiënten en psycho-socialal kwetsbaren, Tweede Kamer, vergaderjaar 1984-85, 18463, nx. 3.

Delimon J (1986), Socloworingen van "Voorburg" "Studiedag Bescherma wonen: aanvulling of alternatief? op 2 oktober, te Utrecht, $\mathbb{N C G V}$.

Dilesfelat HFA (1981), De BOP tien jaar, T Gerontologie en Geríatrie, 12, 139-147.

Drake RE, wallach MA (1979), will mental patienst stay in the community? A social-psychological perspective, J Consult Clin Psychol 47, 2, 285-294.

Drenth PJD (1975), Inleiding in de testtheorie, Van Loghum SIaterus, Deventer. 
Emanuel E (1982), We are all chronic patients, J Chron Disease. Vol. 35, 501-502.

Faden VB, Goldman HH (1979), Appropriateness of placements of patients in state and county mental hospitals, Mental Health Statistical Note 152, Rockville, Md, Division of Blometry and Epidemiology, NIMH.

Farina A, Garmezy N, Zalusky M, Becker J (1962), Premorbid behavior and prognosis in female schizophrenic patients, J Consult Psychology 26, 56-60.

Freeman J (1965), Attitudes to discharge among long-stay mental hospital patients and their relation to social and clinical factors, Brit J Clin Psychology 4, 270-279.

Gadourek I (1969), Sociologische onderzoekstechnieken, Inleiding tot de werkwijze bij het sociaal- en gedragswetenschappelijk onderzoek, Van Loghum Slaterus, Arnhem.

Geerlïngs P, De Klerk-Roscam Abbing J, Schalken H (1983a), De verschillende vormen van psychiatrische dagbehandeling. MGV 5. $511-528$.

Geerlings P (1983b), Antwoord op reactie van W. Scheffer A. van den Hout, MGV 8, 846-848.

GHIGV (1983), Eindrapport van de GHIGV-werkgroep beschermende woonvormen, april, Ministerie WVC.

GHIGV/NZR (1984), Algemene psychiatrische ziekenhuizen 1982, gegevens uit de Patientenregistratie Intramurale Geestelijke Gezondheidszorg (PIGG), Ministerie WVC.

GHIGV/NZR (1985), Algemene psychiatrische ziekenhuizen 1983, gegevens uit de Patiëntenregistratie Intramurale Geestelijke Gezondheidszorg (PIGG), Ministerie WVC.

Giel $R$ (1977), Hospital psychiatry in the Netherlands: buildings or people? Social Psychiatry 12, 89-93.

Giel R, Dijks, Van Weerden-Dijkstra JR (1978), De nieuwe chronische patièntenpopulatie: mededeling uit het centrale patiënten-register (10), T Psychiatrie 20, 601-609.

Giel $\mathbb{R}$, Dijk s, Van Weerden-Dijkstra JR (1978b), Morta1ity in the long-stay population of all dutch mental hospitals. Acta Psychiat scand $57,361-368$. 
Giel R, Sauer H, Slooff C, Wiersma D (1980), Over de epidemiologie van functionele psychosen en invaliditeit, T Psychiatrie $22,11-12,710-722$.

Giel R, Bogaarts (1980), Diagnostische classificatie en codering in de psychiatrie, T Psychiatrie 5 327-335.

Giel $R$ (1982), Warom een psychiatrische diagnose? Een beknopte inleiding in het medische model en in andere modellen, stafleu, Alphen a/d Rijn/Brussel.

Goffman E (1961), Asylums: Essays on the social situation of mental patients and other inmates, Garden City. N.Y. " Doubledèy.

Goldman HH, Gatozi AA, Taube CA (1981), Defining and counting the chronically mentally 111, Hosp \& Com Psychiatry 32, $21-27$.

Goodman $A B$, Siegel C (1986), Elderly schizophrenic inpatients in the wake of deinstitutionalization, Am J Psychiatry 143, 2, 204-207.

Greenblatt $M$, Sharaf M, Stone $E$ (1971), Dynamics of institutional change, Pittsburgh, University of Pittsburgh Press.

Haen $F$ de, Schretlen $E$ (1981), In plaats van een bed, NCGV-reeks nr. 36 .

Hatfield $A B$ (1978), Providing social supports for the families of the mentally ill, Prepared for The President's Commission of Mental Health, Vol. III.

Haveman MJ (1975), Verslag over psychiatrische tussenvoorzieningen in de provincie Gronlngen, Provinciale Raad voor de Volksgezondheld, Groningen.

Haveman MJ (1980a), De frequent opgenomen psychiatrische patiént; draait de draaideur selectief (I)? $T$ Psychiatrie 22, 199-208. Haveman MJ (1980b). De frequent opgenomen patient (II), T Psychiatrie $22,4,267-277$.

Haveman Mu (1980c). Nieuwe langblijvers in psychlatrische ziekenhuizen, MGV $8,642-654$.

Haveman MJ (1981), Oligofrenen in psychiatrische ziekenhuizen, $T$ Psychiatie 23,552-561. 
Haveman MJ (1982a), Beschermende woonvormen; Verslag van een inventariserend onderzoek naar psychiatrische hostels en pensiontehuizen over het jaar 1980 , GHIGV, afdeling anderzoek.

Haveman MJ (1982b), De ontvolking van psychiatrische staatsziekenhuizen in de Verenigae Staten; Enkele oorzaken en gevolgen, MGV 3, 258-279.

Haveman MJ, Brook FG, Burger J (1983), Bescherma wonen als psychiatrische en welzijnszorg; verslag van een inventariserend landelijk onderzoek, T Psychiatrie 5, 343-356.

Haveman MJ (1984), De-institutionalisering van de intramurale psychiatrische zorg; Enkele belleldswensen en ontwikkelingen in Nederland, $T$ Soc Gezondheidszorg 62, nr. 18, 698-706. Haveman MJ, Poelijoe $\mathbb{N W}(1984)$, Verslag van het vooronderzoek "Iong-stay" in P.M.S.Vijverdal; intern rapport, vakgroep Epidemiologie/Gezondheidszorgonderzoek.

Haveman MJ (1986a), Dehospitalization of psychiatric care in The Netherlands, Acta Psychiat Scand 73, 456-463.

Haveman MJ, Poelijoe NW, Tan EIS (1986b), Vervangende zorg voor lang opgenomen patienten in psychiatrische ziekenhuizen; verslag van een landelijk substitutle-onderzoek, vakgroep Epidemiologie/Gezondheidszorgonderzoek, Rijksuniversiteit Limburg.

Hirsch S, Gaind R, Rohde P, Stevens B, Wing J (1973), Outpatient maintenance of chronic schizophrenic patients with long-acting fluphenazine; double-blind placebo trial, Int Med J 1 , $633-637$.

Holland $T$, Konick A, Buffum W, Smith M, Petchers M (1981), Institutional structure and resident outcomes" I Health and soc Behavior, Vol 22, december, 433-444.

Horn GHMM ten (1982), Nazorg geeft kopzorg: Een onderzoek met een register voor de geestelljke volksgezondheld, proefschrift R.U. Groningen, 2 december.

Hout AC van den (1985), Ontslagen psychiatrische patiènten, proefschrift K.U. Nijmegen, april. 
Isele R, Angst J (1985), Social disability in schizophrenia: the controlled prospective Burghölzli study, Eur Arch Psychiatr Neurol scil 234, 341-347.

IWBW (1981). Aanbevelingen voor een beleid ten aanzien van hostels voor psychilatrische patiẻnten en pensiontehulizen voor psychosociaal kwetsbare mensen, Min CRM en Min V \& M, staatsuitgeverij, "s-Graventhage.

Johnstone EC, Owens DG, Gold A, Crow TJ, MacMillan JF (1981), Institutionalization and defects of schizophrenia, Brit I Paychitatry, 139, 195-203.

Jong $A$ de, Giel $R$, Slooff $C$, Wiersma $D$ (1983), Socialle beperkingen ten gevolge van functionele psychosen. I. Een ontwerp voor een model voor de ontwikkeling van sociale beperkingen. T Soc Gezondheidszorg 61, 3, 78-85.

Jong de (1984), over psychiatrische invaliditeit: Een theoretische en empirische verkenning nax het verband tussen psychiatrische ziekte en sociaal gedrag, dissertatie, Drukkerij Van Denderen B.V. , Groningen.

Kam P van der, Wimmers M (1971), Beoordelingsschaal woor Oudere Patienten, Deventer: Van Loghum Slaterus.

Katz RC, Woolley FR (1975), Criteria for releasing patients from mental hospitals, Hosp \& Comm Psychiatry, Vol 26, no. 1 , $687-695$.

Kish G, Solberg $K$, Uecker A (1975), Locus of control as a factor influencing patients' perceptions of ward atmosphere, J Clinical Psychology, 27, 287-289.

Klein R, Klein DF (1968), Marital status as a progrostic indicator in schizophrenia, J Nervous \& Ment Disease 147, 289-296. Koopmans GT, Duurkoop WR, Bouma PD (1982), Ontwikkeling van de Functie Observatie Schalen Hoofdafdeling IV, SES-rapport 7 , Santpoort-Zuid.

Koopmans GT, Buiter RK, Kaatee JA (1983), Structuur, betrouwbaarheid en onderscheidend vermogen van de Functie observatie Schalen Hoofdafdeling IV, SES-rapport B, Santpoort-Zuid. Kris A, Schiff L, MoLaughlin R (1971), Susceptibility to chronic hospitalization relative to age at first admission, Arch Gen Psychiat, Vol. 24, 346-352. 
Lamb HR (1979), Roots of neglect of the long-term mentally 111 , Psychiatry, Vol 42, August, 201-207.

Lamb HR (1982), Treating the longterm menta11y 111 , London, Jossey-Bass.

Liberakis EA (1981). Factors predisposing to institutionalism.

Acta Psychiat Scand 63, 356-366.

Magaro P, Giardina $P$ (1971), Comparing custodial and democratic

treatment programs, Hosp \& Comm Psychiatry 21, 118-119.

Mann SA, Cree W (1976), "New" long-stay psychiatric patients: a

national sample survey of fifteen mental hospitals in England and Wales 1972/3, Psychol Med 6, 603-616.

Mann SA, Sproule J (1972), Reasons for a six-months stay, in* Wing JK, Haily AM (eds.), Evaluating a community psychiatric service, Oxford University Press, London.

Mannoni FV, Shore MF (1974), Family structure, aftercare and post-hospital adjustment. Am J Orthopsychiatry 44, 76-85. Mathai PJ, Gopinath PS (1986), Deficits of chronic schizophrenla

in relation to long-term hospitalization, Brit J Psychiatry $148,509-516$.

Mayer JE, Rosemblatt A (1974), Clash perspective between mental patients and staff, Am J Orthopsychiatry $44,3,432,-441$. Mechanic D (1980), Mental health and social policy, $2^{\text {nd }}$ edition, Englewood Cliffs, N.J., Prentice Hall.

Meyers $N(1977)$, Zorg om kinderen bij opname van de moeder in een psychiatrisch centrum, T Psychiatrie, 2, 122-127.

Ministerie WVC (1983b), Overzicht intramurale en semimurale voorzieningen geestelijke gezondheidszorg per 1-1-1983, GHIGV, afdeling onderzoek.

Minkoff $\mathrm{F}$ (1978), A map of chronic mental patients, in: Talbott JA (ed.): The chronic mental patient, Ad Hoc Committee on the chronic mental patient, Washington, D.C.., American Psychiatric Association, $11-37$.

National plan for the chronically mentally 111 , final draft report to the secretary of health and human services, Washington D.C.., August 1980 .

NCGV (1985), GGZ in getallen 1983, NCGV-reeks 85, Utrecht. 
Nehrevabja $J$ (1973), Analyse von Panel-Befragungen, in (König a ed.). Handbuch der empirischen sozialforschung, Ferdinand thike Verlag, Bnd 2, 191-227.

offerhaus RE (1976), Onderzoek net behulp van een ADL-schaal en de Bop in het psychiatrisch centrum st. Bavo, Ned $T$ Geront, 7. 160-168.

offerhaus RE (1983), Wachten op oneindig; de chronische patient in de psychiatrische inrichting, Van Loghum slaterus, Deventer.

Okin RL (1983), The future of state hospitals: should there be one? Am J Psychiatry, 140, 5, 577-581.

Orme JE (1973), Long-stay psychiatric patients, in: (P Mittler, ed.) The psychological assessments of mental and physical handicaps, Tavistock Publ Methuen Lta.

Paul GL, Lentz RJ (1977), Psychosocial treatment of chronic mental patients, part 1, 1. The chronically institutionalized mental patient, Harvard University Press.

Pepper B, Kirshner M, Ryglewicz H (1981), The young adult chronic patient: oxerview of a population, Hosp \& Comm Psychiatry, Vol 32, no. 7, 463-469.

Peterson $R$ (1978), What are the needs of chronic mental patients? in: (Talbott JA, ed.) The Chronic Mental Patient - Problems, Solutions and Recommendations for a Public Policy, APA, Washington $\mathrm{DC}$.

Pinkhoff-Hilfman (1984), Geneeskundig woordenboek, $8^{\text {site }}$ geheel herziene uitgave, Bohn, Scheltema \& Holkema, Utrecht-Antwerpern.

Pokorny A, Thornby J, Kaplan H, Bal1 D (1976), Prediction of chronicity in psychiatric patients, Arch Gen Psychiatry, vol 33. $932-937$.

Presly AS, Grubb AB, Semple D (1982), Predictors of succesful rehabilitation in long-stay patients, Acta Psychiat Scand 66, 83-88.

Rediloh F", Kellert SR (1978), Trends in American mental health, Ain J Psychiat $135,22-28$.

Reid DD (1960), Epidemiological methods in the study of mental disorders, WHO, Geneva. 
Robbins E, Stern M, Robbins L, Margolin L (1978), Unwelcome patients: where can they find asylum? Hosp \& Comm Psychiatry. Vol 29, no. 1, 44-46.

Romime MAJ (1984), Vexschillende manieren van orngaan met moejlijke mensen, T Psychiatrie 26, 7, 528-533.

Rosenblatt $A$, Mayer JE $(1974)$, The recidivism of mental patients: a review of past studies, Am I Orthopsychiatry, 697-706. Scheffer $W$, Van den Hout $T$ (1981), Psychiatrische centra voor dag-, avond-, en nachtbehandeling; Een onderzoek onder excliënten, behandelaars en verwijzers, ITs, Nijmegen.

Scheffer $W$, Van den Hout $T$ (1983), De verschillende vormen van psychatrische dagbehandeling (2), MGV $8,843-848$.

Schene AH, Gersons BPR (1985), De effectiviteit van psychiatrische deeltijdbehandeling; een overzicht, T Paychiatrie 9 , $634-656$.

Scheuch EK (1974), Auswahlverfahren in der Sozialforschung, Band 3a, 1-96, in: (König R, ed.) Handbuch der empirischen Sozialforschung, Ferdinand Enke Verlag, stuttgart.

Schipper JA (1978), De chronische patiënt; behandeling van een bejegening, T Psychiatrie 5, 285-293.

Schalte JA, Uffing $J$ en Romme MAJ (1982), Langdurig verblijf in het algemeen psychlatrïsch ziekenhuis; een vergelijkende studie, R.U. Limburg.

Schouten HJ (1985), Statistical measurement of interobserver

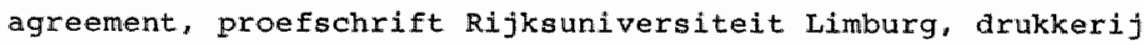
Elinkwijk B. V. Utrecht.

Schudel WJ (1976), Opgenomen ...., opgegeven? proefschrift Rijks universiteit Groningen, Van Loghum Slaterus, Deventer.

Schwartz SR, Goldinger SM (1981), The new chronic patient: clinical characterlistics of an emerging subgroup, Hosp com Psychiatry, Vol 32 , no. $7,470-474$.

Segal SP, Baumoh1 J, Johnson E (1977). Falling through the cracks: mental disorder and social margin in a young vagrant population, Social problems, Vol 24, no. 3, February, $387-400$.

Segal SP, Everett-Dille L (1980), Coping styles and factors in male/female social integration, Acta Psychiat sicand 61, 8-20. 
Shadish WR, Orwin RG, Silber BG, Bootzin RR (1985), The subjective well-being of mental patients in nursing homes, Evaluation and Program Planning, Vol. 8, 239-250.

Shore MF, Shapiro $R$ (1979), The effect of deinstitutionalization of the state hospitals, Hosp comm Psychiatry, Vol 30, no. 9. $605-608$.

Siegler M, Osmond H (1976), Models of madness, models of medicine, Harper \& Row, New York.

Silverman M (1971), Comprehensive Department of Psychological Medicine: three-year review of inpatients referred for aftercare visits, Brit Med J, 99-101.

Slooff CJ (1983). Ziekteduur en meetresultaten; Een methodologisch probleem bij epidemiologisch onderzoek naar niet-affectieve functionele psychosen, $T$ soc Gezondheidszorg 21 . $761-764$.

slooff $C J$, Mulder-Hajonides van der Meulen WR, Van den Hoofdakker RH (1983). De Mederlandse vertaling van de Present state Examination ge editie, I. Betrouwbararheidsaspecten, T Psychiatrie 3, 151-163.

Solomon $P$, Doll $W$ (1979), The varieties of readmission: the case against the use of recidivism rates as a measure of programm effectiveness, Am J Orthopsychilatry 49, 2 .

Strauss JS, Carpenter WT (1977), Prediction of outcome in schizophrenid, III. Five year outcome and its prediction, Arch Gen Psychiat $34,159-163$.

Summers $F$ (1979), Social dysfunction in chronic mentall patients: toward a dual theory of chronic psychopathology. The Psychiatric Forum, Fal1, 55-66.

Swanborn PG (1981), Methoden van social-wetenschappelijk onderzoek, Boom, Meppel.

Talbott JA (1.979), Deinstitutionalization: Avoiding the disasters of the past, Hosp \& Comm Psychiatry 30, 621-624.

Test MA, Stein LI (1976), Practical guidelines for the community treatment of markedly impaired patients, Conm Mental Health I. Vol $12,1,72-82$.

Test MA, stein LI (1977). A community approach to the chronically disabled patient, Social Policy, May/June, 8-16. 
Test MA, stein LI (1978), Community treatment of the chronic patient: research overview" Schizophrenia Bulletin 4, 350-364. Test MA, Knoedler WH, Allness DJ (1985), The long-term treatment of young schizophrenics in a community support program, in: Stein LI \& Test MA (eds.): The training in Community Living Model: A decade of experience, New Directions for Mental Health Services, no. 26, San Francisco, Jossey-Bass.

Thest MA, Knoedler WH, Allness DJ, Burke Ss (1985), Characteristics of young adults with schizophrenic disorders treated in the community, Hosp \& Comm Psychiatry, Vol. 36,

Verstrekkingenbesluit ziekenfondsverzekering (1973). Psychiatrische dagbehandeling, Ziekenfondsraad, Amstelveen.

Vetter $P$ (1985), Die Rehabilitation psychisch Behinderter In Wohngemeinschaften und ihr Einfluss auf die Hospitalisierungsdauer, Der Nervenartz 56, 359-364.

Visiecommissie st. Bavo (1973), De chronische patiënt, 2 rapport, Noordwijkerhout.

Walker $R$, McCourt J (1965), Employment experiences among 200 schizophrenic patients in hospital and after discharge, Am J Psychiatry 122, 316-319.

Watt JA, El-Guebaly N (1981), The chronic mental patient, the position of the Canadian Psychlatric Association, Can J Psychiatry, Vol. 26, November, 494-501. watts $F$ (1983), Socialization and social integration, in ( $F N$ Watts \& DH Bennett) Theory and practice of psychiatric rehabilitation. John wiley \& Sons, Ltd.

Webster English College Dictionary (1984), Longman Group Lim."

Longman House, Burnt Mi11, Harlow, Essex, England. Weerden-Dijkstra $J$ van (1976), Mededelingen uit het centrale patiëntenregister voor psychiatrische ziekenhuizen en universiteitsklinieken (8), T Psychiatrie 2, 120-132.

Weinstein AS, Dipasquale D, Winsor F (1973), Relationships between length of stay in and out of the New York state mental hospitals, Am J Psychiatry 130, 905-908. Wennink HJ, Zuilhof JJ (1984), Kleinschaligheid werkt, T Psychiatrie $26,4,262-274$. 
Wiersma D, De Jong A, Giel R, Slooff C (1983), Sociale beperkingen ten gevolge var functionele psychosen. II. Enkele bevindingen betreffende het model poor de ontwikeling wan sociale beperkingen, T Soc Gezondheidszorg 61, no. 5, 168-174.

Wiersma D, Giel $\mathbb{R}$, De Jong A, slooff CJ (1984), Chroniciteit bij functionele psychosen, T Psychiatrie 26, 6, 402-419. wilder $J$, Lengk A, Zwerling $D(1966)$, A two year follow-up evaluation of acute psychotic patients treated in a day hospital, Am J Psychiatry 122, 1095-1101. Wilensky H, Lebeaux $C$ (1965), Industrial society and social welfare, Free Press, New York. Wing JK, Brown GW (1961), Social treatment of chronic schizophrenia* a comparative survey of three mental hospitals, J Ment Sei. 107, 847-854.

Wing JK (1962), Institutionalism in mental hospitals, Brit J Soc Cdin Psychology $1,38-51$.

Wing JK, Monck $E$, Brown $G$, Carstairs $G$ (1964), Morbidity in the community of schizophrenic patients dischafrom London mental hospitals in 1959, Brit J Psychiatry 110, 10-21.

wing JK (1966), Social and psychological changes in a rehabilitation unit, Soc Psychiatry 1, 21-28. Wing $J K(1967)$, Social treatment, rehabilitation and management, in (A Coppen A Walk) Recent developments in schizophrenia, Ashford: Headley Brothers/RMPA.

Ziekenfondsraad (19B4), Advies inzake een stelsel van (intramura1.) psychiatrische verstrekkingen aan de statassecretaris van WVC, ziekenfondszad nr. 249.

Zwan AH van der (1982), Patientenstromen door een psychiatrisch ziekenhuis, Gezondheid \& Samenleving jrg. 3, no. 3, $175-183$. 
$-251-$

BDLAGEN 
$-252-$

BDL AGE 1 
VRAGENLIJST ONDERZOEK LONG-STAY PSYCHIATRIE (VOLI)

(Psychiater, Psycholoog. Maatschappelijk werker)

Naam patiënt:

Geslacht:

Geboortedatum:

Opnamedatum:

Verblijfplaats in de instelling:

Onderzoeknummer:

Naam respondent:

Functie:

Schutblad na invulling afscheuren en de ingevulde vragenlijst d.m.v. bijgevoegde enveloppe retourneren.

\section{HANDLEIDING}

- Graag ledere wraag beantwoorden, tenzij anders is aangegeven.

- Geef Uw antwoord bil elke uitspraak door slechts éen van de cijfers te omcirkelen.

- Staat een pijltje achter thet door U omcirkelde woord dan wordt verwezen naar de volgende vraag en kunt $U$ één of meer vragen oversiaan.

- Gaarne ook de open vragen zo exact en volledig mogelijk beantwoorden. Indien onvoldoende ruimte is gereserveerd voor Uw antwoord kunt U gebruik maken van de achterkant van de pagina, met verwijzing naar het nummer van de viraag.

- Controleer de ingewulde wragenijjst nog eens op eventuele onvolledige of onnauwkeurige antwoorden. 


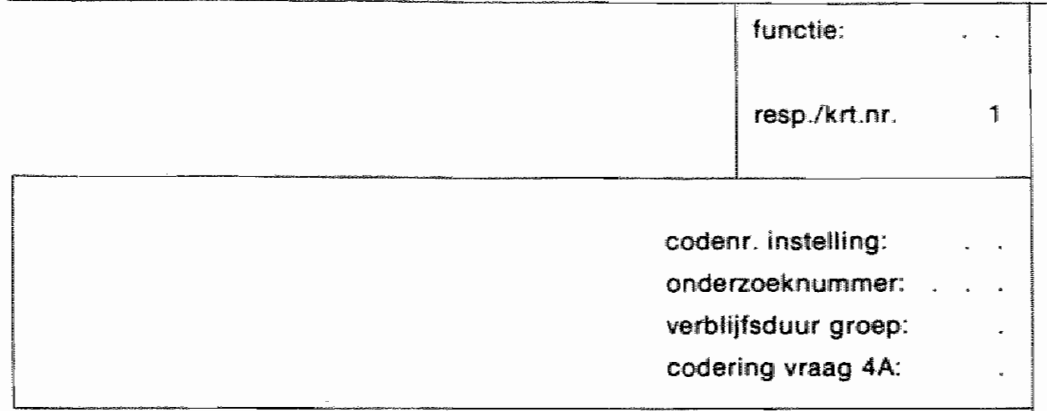

1 is betrokkene woorafgaand aan het verbliff in de huidige instelling ooit langer dan 5 jaar continu"opgenomen geweest in een psychiatrisch ziekenhuis?
$0-\{a-$ (door naar wraag 4 )
1 - nare

2 Is betrokkene woorafigaand aan het verblijf in de huidige instelling ooit korter dan 5 jaar maar wel langer dan 2 jaar continu" opgenomen geweest in een psychiatrisch ziekenhuis?

$$
\begin{aligned}
& 0 \text { - ja } \rightarrow \text { (door naar vraag 4) } \\
& 1 \text { - nee }
\end{aligned}
$$

3 is betrokkene gedurende een periode van 5 jaar direct voorafgaand aan het werblijf in de huidige instelling meerdere keren opgenomen geweest in een psychiatrisch ziekenhuis ( 2 of meer keer) met een totale werbliffsodur van langer dan 30 maanden?
$0-j a \rightarrow$ (door naar vraag 4)
1 - nee

4. Datum van laatste opmame: (iin het dagziekenhuis/beschermde woonvorm) (maand) (jaar)

4A Hoeveel jaren geleden is betrokkene voor het laatst ontslagen uit een psychiatrisch ziekenhuis?

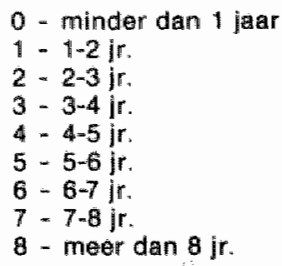

5 Goboortejaar:

- Weekendverlot, vakantie, ziekte (ziekenhuisopname), interne overplaatsing en overplaatsing vanuitt een andere psychiatrische instelling (paaz, psychiatrisch ziekenhuis, verslawingskliniek) wordt daarbij niet beschouwd als een onderbreking van de opname periode. 
6. Geslacht

a - man

1 - vrouw

7 Burgerilike staat

o- ongehuwd

1 - gehuwd

2 - gescheiden

3 - weduwstaat

8. Juridische situatie (nu)

a - vrijwillig opgenomen

1 - krachtens inbewaringstelling (i.b.s.)

2 - krachtens rechterlije machtiging

3 - krachtens een strafrechterlijke maatregel

-9 Psychiatrische hoofddiagnose nu léén magelijkheid amcirkeleny

ICD 9 \& DSM III

0 - dementie (seniel \& preseniel) 290

1 - overige organische psychische stoornis (exel. alcohol - en drugpsychose)

$293,294,310$

2 - schizofrenie

295

3 - affectieve psychose

296

4 - overige niet-organische psychose

297,298

5 - neurotische/depressieve stoornis

300,311

6 - persoonlijkheidsstoomis

$301,302,312$

7 - stoornis bill alcohol - of druggebruik

$291,292,303-305$

8 - zwakzinnigheid

317-319

9 - overige stoornissen

299, 306-309,

$313-316$

10. Wordt betrokkene in zijn/haar functioneren beperkt door exn lichamelike ziekte of handicap? (incll epilepsie, maar excl. organische psychische stoornissen en zwakzinnigheid)?

a - ja

1 - nee $\rightarrow$ (door naar wraag 11 )

10a Indien ja, gaarne een omschrijving van de aard van de ziekte/handicap: 
1ob Indien ja, kan betrokkene (met of zonder hulpmiddelen)

- zien?

0 - goed

1 - gedeeltelijk

2 - slecht

- horen?

0 - goed

1 - gedieltelink

2 - sllecht

- spreken?

0 - goed

1 - gedeeltellik

2 - slecht

- lopon?

a - goed

1 - gedeeltelijk

2 - slecht

11a Hoe is de houding van de ouder(s) ten aanzien van eventueel ontsiag naar het ouderlijk huis of onmiddelijke omgeving?

0 - aanvaardend

1 - atwerend

2- ambivalent

9 - onbekend

12 Is betrokkene gehuwd of duurzaam samenwonend 86 mnd.)?

0 - nee $\rightarrow$ (door navar vraag 13)

1 - ja 
12a Hoe is de houding van de partner ten aanzien van ewentueel ontsilag mar huils?

0 - aanvaardend

\#- afwerend

2 - ambivallent

9 - ambekend

13 Heeft betrokkene levende broers en/of zusters?

0 - geen $\rightarrow$ (door naar wraag 14 )

1 - én

2 - meer dan één

9 - onbekend $\longrightarrow$ (door naar vraag 14)

13a Hoe is de houding wan broers/zusters ten aanzien van eventuele inwoning of wonen in de naaste amgeving?
o - aanvaardend
1 - afwerend
2 - ambivalent
9 - onbekend

14 Heeft betrokkene kinderen (inclusief adoptio)?

0 - geen $\rightarrow$ (door naar vraag 15)

1 - eén

2 - meer dan éen

9 - onbekend $\rightarrow$ (door naar vraag 15 )

14a Hoe is de houding wan de kinderen t.a.y. eventuele inwoning of wonen in de naaste omgeving?

0 - aanwaardend

1 - afwerend

2 - ambivalent

9 - onbekend

15 Werd betrokkene in de afgelopen 12 mnd. door $U$ at andere leden van het begeleidingsteam geïnformeerd over mogelijkheden van opvang en werblijf buiten de instelling?
0 - uitwoerig
1 - terloops
2 - nee 
16. Werd in de afgelopen 12 mid. door $U$ of andere leden van het begeleidingsteam met fambie- of gezhisfeden gesproken over eventuele terugkeer naar het thuismilieu?
O - uitvoarig
1 - terloops
2 - nee
9 - n.v. (gean famille/gezin)

17 Werd in de afgelopen 12 mnd. een poging ondernomen om betrokkene bij gezinffamilie te plaatsen?
Q - Ja, meer dan én keer
\#- ja, gen keer
2 - nee - (door naar vraag 18)
9 - n.v.t. (gean familie/gezin) - (door naair vraag 18)

17 Indien ja, waarom werd betrokkene na korte tijd weer opgenomen?

Toolichting:

18 Werd in de afgelopen 12 mnd. een poging ondernomen om betrokkene in een andere voorziening te plaatsen?

0 - ja, meer dan één keer

1 - ja, een keer

2 - neel- (door naar wraag 19)

18 Indlen ja, om welke soort voorziening ging het daarbij? Voorziening:

19 Heeft betrokkene in de afgalopen $12 \mathrm{mnd}$. Weekenden(met overnachting) bij famille - of gezinsleden doorgebracht?
o - nee
1 - ja, 1-2 keer
2 - ja, meer dan 2 keer
9 - n.v.t. (geen familie/gezin) - (door naar vraag 21) 
kolom

0. Welke factoren binnen het gezin beïnvloeden in negatieve zin de mogelijkheden tot thuisplaatsing?

Gaarne omschrijuing:

\# Is zelfstandig wonen of wonen bil famillie/gezin/vrienden nog eén van de doelen bil de huidige begeleiding en behandeling van betrokkene?

$$
\begin{aligned}
& 0 \text { - ja } \\
& 1 \text { - nee }
\end{aligned}
$$

2 - nee

ieef ook bij de volgende vragen Uw antwoord door slechts éen van de ijfers te omcirkellen.

4 Komt betrokkene wolgens $U$, gezien zijn/haar huidige fuctioneren, in aanmerking voor:

1) zeltstandige kamerbewoning (zonder begeleiding vanuit Riagg of polikliniek)?

$0-j a$

1 - misschien

2. - nee

1) zel/standige kamerbewoning (met begeleiding wanuit Riagg of polikliniek)? $0-j a$

1 - misschien

2. - nee 
knolom

c) Vlalhuisbewoning met andere ex-patienten (zonder begeleiding vanuit Alagg of polikliniek)?

$0-$ ja

1 - misschien

2- nee

d) flat/huisbowoning met andere ex-patienten/met begeleiding vanuit Riagg of polikiniek)?

a - ja

1 . misschien

2 - nee

a) beschermd samenwonen in ean woonhuis op het terrein van ten psychiatrisch ziekenhuis?

$0-$ ja

1 - misschien

2 - nee

9 - n.v.t (woont reeds in een dergelijke vootziening)

f) beschermo samenwonen in een woonhuis buiten thet terroin van een psychiatrisch ziekenthuis?

0 - ja

1 - misschien

2 - nee

9 - n.v.t. (woont reeds in een dergelitjke voorziening)

g) psychiatrisch hostel/sluisinternaat (intensieve op ontslag gerichte behandoling in een kleinschalige voorziening)?

o - ja

1 - misschien

2 - nee

$9-\pi . v t$ (verbijft reeds in een dergelijke vaorziening)

* onder personele begeleiding 
h) psychiatrisch dagziekenhuis ('s nachts buj familie/gezin)?

$0-\ddot{m a}$

1 - misschien

2 - nee

8. - n.v.t. (verblijft reeds in een dergelijke woorziening)

9 - n.v.t. (geen familie/gezin)

i) psychiatrisch dagziekenhuis (in combinatie met a, b, c, of $d$, zie vorige pagina)? $0-j a$

1 - misschien

2 - nee

9 - n.v.t. (verblijft reeds in een dergelijke woorzliening)

i) komt betrokkente in aanmerking voor plaatsing in een andere woorziening dan genoemd onder a $\mathrm{t} / \mathrm{m}$ i?

Toelichting:

De volgende drie vragen (25,26 en 27 alleen beantwoorden indien $U$ bij vraag $24 \mathrm{~b}$ of $24 \mathrm{~d}$ "ja" of "misschien" heeft aangekruist!

25 Aan welke voorwaarden dient de hulpverlening vanuit Fiagg of polikliniek te voldoen om betrokkene adequal op te kunnen vangen?

a) persoonlijk contact tussen bewoner en nazorginstantie voordat het ontslag plaatsvindt

o - niet noodzakelijk

1 - aan te bevelen

2 - strikte voorwaarde voor onslag

b) een eerste hullpverleningscontact binnen 2 dagen na ontslag

0 - niet noodzakelijk

1 - aam te bevelen

2 - strikte voorwaarde voor ontslag 
outreaching (begoleidingrondersteuning thuis)

o- niek noodzakelijk

1 - aan te bevelen

2 - strikte woonwarde voor ontsiag

d) aggz-hulp als achterwacht gedurende 24-uvr per dag (ook weekends) opropobar

0 - niet noodzakialjik

1 - aan te bevelen

2 - strikte voorwaarde voor ontslag

e) depot-medicatie

0 - niet noodzakelijk

1 - aian te bewelen

2 - strikte voorwaarde voor onslag

1) advisering en ondersteuning bij thet werkrijgen wan ublkeringen. gezinsthulp. a.d.

0 - niet noodizakelijk

1 - aan te bevelen

2 - strikte voorwaarde voor onts!lag

g) op sociale vaardigheden gerichte ambulante begeleiding/behandeling

0 - niet noodzakelik

1 - aan te bevelen

2 - strikte voorwaarde voor ontsiag

h) de aggz-begeleiding dient t.a.v. betrokkene aan andere voorwaarden te voldoen, zoals:

26 Welke instelling voldoet wolgens $U$ het beste aan de voorwaarden die $U$ bij viag 25 heeft aangegeven?

(slechts ben van de antwoordmogelijkheden aankruisen)

0 - Rlagg (of bén van de teams daarbinner)

1 - Pollikliniek psychiatrisoh ziekenhuis

2 - anderszins, nll.

27 Bent $U$ van mening dat de door $U$ genoemde instelling (bij wraag 26) met betrekking tot beschikbare tijd en middelen reeds nu aan de door $U$ onder vialag 25 genoemde voorwaarden kan voldoen?

$0-j a$

1 - misschien

2 - nee 
ikolom

Dit was het laatste item van deze wragenlijst, en wij willen U dan ook

hartelijk bedanken voor de beantwoording van de vragen.

Eventuele opmerkingen t.a.v. de wragenlijst worden zeer op prijs gestelld:

Zow Ul tenslotte hieronder nog de datum van invulling. Uw naam en functie willen wermelden?

datum.

$78-80$

naam:

functie:

Voor eventuele vragen ta.v. de vragenlijst kunt $U$ contact opnemen met:

Drs. M.J. Haveman

Capaciteitsgraep Epidemiologie Rilksuniwersiteit Limburg

Tell.: $043-888159$
Drs. Poelijoe

Capaciteitsgroep Epidemiologie Rijksuniversiteit Limburg

Tel.: 043 - 888145 
$-264-$

BILLAGE 2 
(Verpleegkundige/menton)

\begin{tabular}{|l|}
\hline Naam patiènt: \\
\hline Geslacht: \\
Geboortedatum: \\
Opnamedatum: \\
Verbliffplaats in de instelling: \\
Onderzoeknummer: \\
Naam respondent: \\
\hline Functie: \\
\hline
\end{tabular}

Schutblad na invulling afscheuren en de ingevulde vragenlijst d.m.v. bijgevoegde enveloppe retourneren.

\section{HANDLEIDING:}

- geef een oordeel over de toestand tijdens de laatste 4 weken voor het onderzcek (tenzij anders is aangegewen):

- omschrijf deze toestand zo nauwkeurig mogelijk door bil elke uitspraak slechis een van de ciffers te omcirkelen:

- geef op alle punten een beoordeling, ook in geval van twijfel; vermeld eventuele problemen met de invulling op p. 13;

- kijk de ingevulde wragenlijst nagl eens door op eventuele onvolledige en onnauwkeurige antwoorden. 
VRAGENLIJST ONDERZOEK LONG-STAY PSYCHIATRIE (VOL. II)

(Verpleagikundige/mentor)

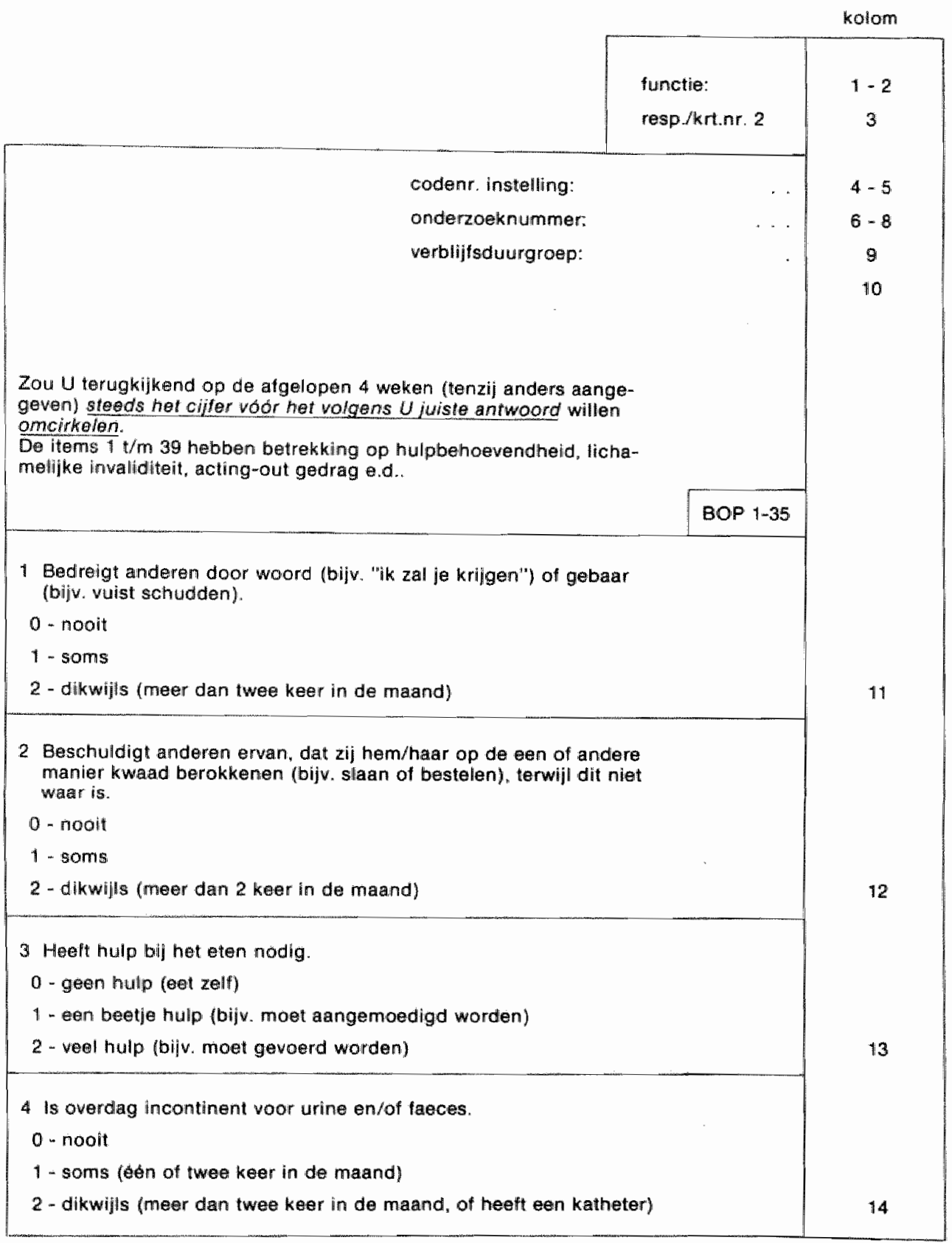


5 Siaat of schopt anderen.

0 - nooit

- soms

2 -dikwills (meer dan 2 keer in de maand)

6 Er zijn speciale voorzieningen nodig om te voorkomen dat hilizil van de stoel watt.

0 - nooit

1 - soms

2 - dikwijls

7 Gedraagt zich overdag hinderlijk ten opzichte van andere bewoners (bijy. luid of aan een stuk door praten, dingen van anderen pakken, zich mot andermans zaken bemoeienj.

a - nooit

1. soms

2 - dikwijls (meer dan 2 keer in de maand)

$B$ is somber of verdrietig.

0 - nooit

1 - soms

2 - dikwilis/voortdurend.

9 Kan Iopen.

0-zonder moeite

1 - langzaam zonder hulp, of met een stok

2 - helemaal niet, of alleen met ondersteuning (bijv. menselijke hulp, looprek)

to Kan andieren duidelijk maken wat hij/zi) bedoelt (door spreken" schrijven of gebaren).

0 - altijo

1-soms

2 - bijna nooit

11 Weet in het tehuis of de linrichting de weg te vinden (bijv. naar zijn/haar kamer, het toillet, zijn/haar plaats aan tafely.

0 - over het algemeen wel

1 - sommige plaatsen wel, andere niet

2 - over het algemeen niet

12 Beseft in wat voor soort tehuis of inrichting thij/zij is.

$$
\begin{aligned}
& 0 \text { - altijd } \\
& 1 \text { - soms } \\
& 2 \text { - nooit }
\end{aligned}
$$


13 Kent het personetel bij naam.

0 - meer dan én personeelsild

1 - slechts sen persaneelislid

2 - geen enkel personeelsid

14 Begrifot wat U hem/haar duldelijk wilt maken (U mag daarbij spreken. schrijuen of gebareny.
0 - altijd
1 - soms
2 - nooit

15 Hellpt op de afdeling (bijv. afwassen, bloemen verzorgen, stoffen) of elders (biliv. tuin, wasserij, naaikamer).

0 - dikwijls (meer dan 2 keer in de maand)

1 - soms.

2- nooit

16 Uit lichamelijke klachten (zonder dal daarvoor een oorzaak c.q. aanieiding bestaat:
Q - nooit
1- soms
$2-$ dikwijls

17 Reageent op het noemen van zijn/haar naam.
0- altijd
1 - soms
2- nooit

18 is ook buiten de therapie actief (bijw. werken, lezen, spelletjes doen, nobbies, met anderen praten].
0- altijd
y- soms
2 - nooit

19 Huilt bij de geringste aanleiding.
0 - noolt
1 - soms
2. dikwijls

20 Gaat met eien of meer bewoners om

0 - dikwijls (grootste gedeelte van de dag)

1 - soms

2 - nooit 
21 Urineert of deponeert faeces op plaatsen, die daarvoor niet bestemd zijn.

0 - nooilt

1 -soms (1 of 2 keer in de maand)

2 - dikwijls (meer dan 2 keer in de maand)

2.2 Helpt andere bewoners wel eens ongevraagd een handje (bijv. wandelen. eten, spel e.d.).

a-dikwills (meer dan 1 keer per dag)

1. soms

2- nooit

23. Is bereid to doen wat hem/haar gevraagd wordt.

0 - dikwijls

1 - soms

2 - nooit

24 Komt buiten het terrein van de instelling.

0- - dilkwijls (biina jedere dag)

1 - soms

2 - noolit

25 Maakt steeds dezelfde overbodige bewegingen (bijv. heen en weer lopen, op en neer wiegen, handen wringen, plukken aan kleding).

0 - nooit

1 - soms

2 - dikwijls (meerdere keren per dag)

26 Maakt geluiden die tot niemand in het bijzonder zijn gericht (bijw. schreeuwen, kreunen, mompelen).

0 - nooit

1 - soms

2 - dikwijls (meerdere keren per dag)

27 Knoopt uit zichzelf een praatje aan met andere bewoners.

0 - dikwijls (meerdere keren per dag)

1. soms

2 - nooit

28 Mag de straat op.

0-zonder toezicht

1 - alleen in gezelschap van een ander

2- hellemaal niet 
29 Maak zich gauw kwaad.
0. noot
$1-\operatorname{som} s$
2 - dikwils

30 Zit owerdag te suffen.
0 - nooit
1-somis
2-dikwills (grootste gedeelte van de dag)

31 Heeft bil het aankleden hulp modig.
o - gean hulp
1 - een beetje hulp
2 - volledige hulp

32. is 's nachts incontinent vooir urine en/of faeces.
0 - nodit
1 - soms (11 of 2 keer in de maand)
2 - dikwijls (meer dan 2 keer in de maand, of heeft een katheter)

33 Er zijn speciale voorzlleningen nodig om te voorkomen dat hij/zij uil bed valt (bijv, een opstaande rand).
0 - mooit
1 - soms
2- dikwilils

34. Gedraggt zich 's nachts onaangenaam voor andere bewoners (bijw. luid of aan een stuk door praten, rondlopen, in het bed van een ander kruipen).

0 - nooit

1 - soms (minder dan 4 keer in de maand)

2 - dikwijls (4 of meer keer in de maand)

35 Is 's machts onrustig (roken, wark naar tollet, weglopen e.d."

$$
\begin{aligned}
& 0 \text { - nooit } \\
& 1 \text { - soms } \\
& 2 \text { - dikwills (meer dan } 2 \text { keer in de week) }
\end{aligned}
$$

36 Spreekt de Nederlandse taal (incl. dialakt)

$$
\begin{aligned}
& 0 \text { - goed } \\
& 1 \text { - gabrekkig (enkelle woorden) } \\
& 2 \text { - niet lalleem buitenlandse taal stom) }
\end{aligned}
$$


37 Verstaat de Nederlandse taal.

o - goed

1 - gebrekkig (enkele woorden)

2 - nitet (alleen buitenlandse taal, volledig doof)

38. Heeft in de afgelopen 3 maanden gedreigd met suicide.

0 - nooit

1 - samsi (1 keer)

2 - dillkwijls (meer dan 1 keer)

39 Heeft in de afgelopen 3 maanden suicidepoging(en) ondernomen

0 - nooit

1 - soms (1 keer)

2 - dillkwijls (meer dan 1 keer)

De items $40 \mathrm{t} / \mathrm{m}$ 43 geven een antal potentiele sociale vaardigheden aan die belangrijk zljn om zelfstandig te kunnen leven. Gevraagd wordt een inschatting te geven wan de mogelfikheden van betrokkene. Voor een adequate beantwoordilng is het noodzakelijk om per vraag de handleiding op pag. 14 the raadplegen.

$40 \mathrm{Zal}$ in staat $z$ ijin om van het openbaar vervoer gebruik te maken.
0 - goed
1 - gedeeltelijk
2- niet

41 Zal in staat zijn om een eenvoudige warme maaltijd te bereiclen.
0 - goed
1 - gedeellelijk
2 - niet

42 Zal in staat zijn om boodschappen te doen.

$$
\begin{aligned}
& \text { 0-goed } \\
& \text { - gedealteliak } \\
& 2 \text { - niet }
\end{aligned}
$$

43 Zal in staat zljn zelf iemand op te bellen.

$$
\begin{aligned}
& 0 \text { - goed } \\
& 1 \text { - gedeeltelijk } \\
& 2 \text { - niet }
\end{aligned}
$$


kolom

Met de itemis $44 \mathrm{t} / \mathrm{m} 61$ word gevraagd naar de contacfrequentie en -intensiteif

van de bewoner met dingen, gebeurtenissen en personen buiten de instelling.

44. Telefoneert zelt met anderen (kennissen, vrlenden, familie

0 - dikwifis (meer dian 2 keer in de maand)

1 - soms ( 1 of 2 keer in de maand)

2 - nooit

45 Wordt door anderen opgebeld (kennissen, wrienden, famille).

0 - dikwilits (meer dan 2 keer in de maand)

1 - soms ( 1 of 2 keer in de maand)

2 - nooit

46 Schrijft anderen brieven of kaarten

0 - dikwijls (meer dan 2 keer in de maand)

1 - soms ( 1 ol 2 keer in de maand)

2 - nooit

47 Krijgt brieven en kaarten toegestuurd.

a-dikwijls (meer dan 2 keer in de maand)

1 - soms (" of 2 keer in de maand).

2 - nooit/zeer zelden

48 Gaat midden in de week op bezoek bij personen (kennissen, vrienden, famillie) die buiten de instelling wonen.

0 - dikwijls (meer dan 2 keer in de maand)

1 - soms ( 1 of 2 keer in de maand)

2 - nooit/zeer zelden

49 Blijt het gehele weekend bij familie, vrienden of kennissen.

0 - dikwljis (meer dan 1 keer in de maand)

1 - soms (1 keer in de maand)

2 - nooit/zer zellden

50. Krijgt bezoek van kennissen, vrienden of familie die buiten de instelling wonen.

0 - dikwils (meer dan 2 keer in dle maand)

1 - soms (1 of 2 keer in de maand)

2 - nooit/zeer zelden 
51 Gaat op vakantie.

0 - dikwijls (bijna ieder jaar)

1) - soms

2 - nooit

52 Bezoekt bioscoop, theater, concert of kerk buiten het terrein.

0 - dikwifls (meer dan 2 keer in de maand)

1 - soms (1 of 2 keer in de maand)

2 - nooit

53. Doet mee aan uitstapjes gearganiseerd door de instelling.

0 - altijd

1 - soms

2 - nooit

54 Onderneemt zonder personele begeleiding activiteiten (bijv. fletsen. wandelen, zwemmen) buiten het instellingsterrein.

0 - dikwijls (meer dan twee keer in de maand)

1 - soms ( 1 of 2 keer in de maand)

2 - nooit/zeer zelden

55 Onderneemt samen met personeel activiteiten (bijv. fietsen, zwemmen, wandelen) buiten het instellingsterrein.

0 - dilkwijls (meer dan 2 keer in de maand)

1 - soms (1 of 2 keer in de maiand)

2- nooit/zeer zelden

56 Doet boodschappen buiten het terrein van de instelling.

0 - dikwijls (meer dan 2 keer in de maand)

1 - soms (" of 2 keer in de maand)

2- nooit/zeer zelden

57 Verricht betaald of onbetaald werk buiten de instelling (bijw. sociale werkplaats, baan, klusjes).

0 - dikwijls (meer dan 4 keer in de maand)

1 - soms ( 1 tot 4 keer in de maand)

2 - nooit

58. Leest de krant.

0 - dikwijls (bijna dagellijks)

1 - soms

2 - noait 
59 Leest tijdschriften (week - of hobbybiaden)

o-dikwils (meer dan vier keer in de maand)

1 - soms (minder dan vier keer in de maand)

2- nooit/zeer zelden

60 Kinkt televisie.

a-dikwijls: (bijna dagelijks)

1 - soms

2 - nooit

61 Praat met personeel of medebewoners over gebeurtenissen (vernomen wia krant radio, t.v.) buiten de instelling.

0 - dikwijls (bijna dagelijks)

1 - soms

2- nooft

62 Werd betrokkene in de atgelopen $12 \mathrm{mnd}$. door $U$ of andere leden van thet begeleidingsteam geünformeerd ower mogelijkheden wan opwang en verblijf buiten de instelling?

0 - uitvoerig

1 - terloops

2- nee

63 Werd in de afgelopen 12 mnd. door $U$ of andere leden van het begeleidingsteam met familio- of gezinsloden gesproken over eventuelle terugkeer naar het thuismilieu?

0 - uitwoerig

1 - terlaops

2 - nee

9 - n.v.t. (geen familie/gezin)

64 Werd in de afgelopen 12 mnd. een poging ondernomen om betrokkene bij gezin/familie te plaatsen?

$0-1 a$, meer dan én keer

1 - ja, én keer

2- nee

9- n.v.t. (geen familie/gezin)

65 Werd in de afgelopen 12 mnd. een poging ondernomen om betroklkene in een beschermende woonvorm of psychiatrisch dag-/nachtziekenhuis te plaatsen?

0 - ja, meer dan een kear

1 - ja, een keer

2- nee

9 - n.v.t. (betrokkene verblijft reeds in een dergelijke voorziening) 
65a Indien ja, om welk soort voorzlening ging het daarbij?

Toellichting:

65b Indien ja, welke factoren belemmerden definitieve plaatsing?

Toelichting:

66 Zal betrokkene volgens $u$ in de komende 6 maanden uit Uw instelling worden ontslagem?

o- ja

1 - misschien

2 - nee

Graag steeds eén van de cijfers voor de drie antwoordmogelijkheden omcirkelten.

\section{functie}

resp./krt.nr.

codenif: inst.

onderz $n$.
$1-2$

3

$4-5$

$6-8$

67 Komt betrokkene wolgens 4 , gezien zijn/haar huidige functioneren in aanmerking vooir:

a) zelfstandige kamerbewoning (zonder begeleiding vanuit Riagg of pollikliniek)

$0-$ ja

1 - misschien

2 - nee

b) zelfstandige kamerbewoning (met begeleiding vanuit Rlagg of polikliniek)

$0-$ ja

1 - misschien

2 - nee

c) flat-/huisbewoning met andere ex-patiënten (zonder begeleiding vanuit Riagg of polikliniek)

0 - ja

1 - misschien

2 - nee

d) flat-/huisbewoning met andere ex-patienten (met begeleiding vanult Riagg of polikliniek)

$0-$ ja

1 - misschien

2 - nee 
vervolg vraag 67 : Komt betrokkene volgens $u$, gezien zijn/haar huidige functioneren, in aammerking voor:

e) beschermd samenwoinen ' in een woonhuis op het terrein wan een psychiatrisch ziekenhuis

0. ja

1 - misschien

2 - nee

9 - n.w.t. (woont reeds in een dergelijke voorziening)

1) beschermd samenwonen" in een woonhuis buiten het terrein van een psychiatrisich zlekenhuis

0 - ja

1 - misschilen

2- nee

9 - n.v.t. (woont reeds in een dergelijke voorztening)

g) psychiatrisch hostel/sluisintermaat (intensiewe op ontslag gerichte behandeling)

$0=$ ja

1 - misschien

2- nee

9 - n.v.t. (verblijft reeds in een dergelijke voorziening)

h) psychiatrisch dagziekenhuis ("s nachts bij familie/gezin)

$0-$ ja

1 - misschien

2 - nee

8 - n.v.t. (verblijft reeds in een dergelijke voorziening)

9 - n.v.t. (geen familie/gezin)

i) psychiatrisch dagziekenhuis (in combinatie met $a, b, c$ of $d_{n}$ zie vorige pagina)

$0-j a$

1 - misschien

2- nee

9 - n.v.t. (verblijt reeds in een dergelijke voorziening)

i) komt betrokkene in anmerking voor plaatsing in een andere vaorziening dan genoemd onder $\mathrm{t} / \mathrm{m} \mathrm{i}$ ?

68 is zeltstandig wonen of wonen bij familie/gezin/vrlenden nog eén van de doelen bij de huidige begeleiding ein behandeling van betrokkene?

0 - ja

1 - nee 
69 Is betrokkene naar uw mening berreid toe te werken naair ontslag?

$0-$ ja

1 - nee

70 Heeft betrokkene een eigen bank- of girorekening (incl. dependance van bank in het psychiatrisch ziekenhuis)?

o- ja

1 - nee

$70 a$ Indien ja $a_{1}$ an betrokkene naar eigen goeddunken over de gestorte bedragen beschikken?

0 - ja

1 - nee

$9-$ n.v.t.

71 is betrokkene in de afgelopen 12 mnd een week of meer op vakantie geweest?

0 - ja, alleen

1 - ja, samen met andere patiënten (zonder personeal)

2 - ja samen met andere patiënten (met personeell)

3 - ja samen met gezins- of familleleden

4 - jáa samen met kennissen of vriendien

5 - nee

72 Stel dat betrokkene graag 2 weken op vakantie will gaan naar éen van de Nederlandse eillanden:

a) Zou u bezwaar maken indien hij/zij alleen wil gaan?

$0-$ nee

$1-$ ja

b) Zou u bezwaar maken indien hij/zij met andere bewoners will gaan, maar zonder personelel?

0 - nee

$1-$ ia

c) Zou u bezwaar maken indien hij/zil samen met gezins- of familieleden will gaan?

o- nee

1 - ja

d) Zou u bezwaar maken indien hij/zij samen met andere bewoners wil gaan. maar met personeel?

0 - nee

$1-j a$ 
kolom

Met dil item zin wij tevens aan het einde gekomen van deze vragenijst. Wij willen u dan ook hartelik bedamken voor de beantwoording wan de vragen.

Eventuele opmerkingen t.a. . de vragenlifst worden zeer op prijs gesteld:

Zou u tenslotte hieronder nog de datum van invulling. uw naam en functie willen vermelden:

Detum:

Naam:

Functio/opteiding:

Voor eventuele vragen t.a.w. die wragenlijst kunt u contact opnemen met:

Dis. M.J. Haweman.

Capaciteitsgroep Epidemiologie Rijksuniwersiteit Limburg

Tel. $043-888159$
Dirs. N. Poelijoe

Capaciteitsgroep Epidemiologie

Rijksuniversiteit Limburg

Tel. $043-888145$ 
Handleiding potentiele sociale vaardigheden (items $40-43$ ).

ad 40: Onder gebruikmaken van openbaar vervoer worden alle handelingen werstaan die iemano moet verrichten om zich met bus $s_{1}$ tram of trein over een van te woren bepaalde route te verplaatsen.

- Goed in staat tot gebruikmaken van openbaar vervoer:

betrokkene zal geheel zelfstandig de juiste bus, tram of trein kiezen naar meerdere bestemmingen, kaantje/strippenkaart kopen en op de juiste bestemming uitstappen.

- Gedeeltelijk in staat tot gebruikmaking van openbaar wervoer:

betrokkene zal alleen de bus, tram of trein naar éen bestemming weten te vinden, nog wel eens op een andere bestemming aankomen, of bij een enkele handeling hulp nodig hebben.

- Niet in staat tot gebruikmaken van openbaar verwoer:

betrokkene zal alleen onder begeleiding van anderen kunnen reizen.

ad 41: Onder bereiden van een eenvoudige warme maaltijd worden alle handelingen verstaan die iemand moet verrichten om een èem-pans-gerecht (b.v. maccaroni, boerenkool e.d.) klaar te maken.

- Goed in staat tot het bereiden wan een eenvoudige warme maaltijd: betrokkene zal zonder hulp of begeleiding gebruilk kunnen maken van een ellektrisch- of gas-kookstel, de groente snijden en wassen, de benodigde hoeveelheid ingrediënten goed bepalen; de toebereiding zal plaats vinden in de juiste volgorde met een aanvaardbaar resultaat.

- Gedeeltelijk in staat tot het bereiden van een eenvoudige warme maaltijd: betrokkene zal onder hulp of begeleiding een eitje kunnen bakken of soep uit blik of pakje bereiden. Voor het bereiden vam een éen-pans-gerecht zall betrokkene echter bij enkele handelingen hulp nadig hebben.

- Nief in staat tot het bereiden van een eenvoudige warme maaltijd: betrokkene zal aangewezen zijn op het koken doar anderen.

ad 42: Onder boodschappen doen worden alle handelingen verstaan die iemand moet verrichten om dagelijkse gebruiksgoederen (levensmiddelen, kleding "briefpapier, e.d.) te kumnen kopen.

- Goed in staat boodschappen te doen: betrokkene zal in staat zijn om een bedrag van ca. 75 ,-- per week zelfstandig te beheren en op een aanwaardbare manier te besteden aan dagelijkse gebruiksgoederen. Aan een bepaald produkt (alcohol, zeep, drop e.d.) zal niet buiten alle proporties geld worden besteed. Betrokkene zal eem baodschappenlijst kunmen samenstellen, de produkten op vermoedelijke kostprijs schatten, de betreffende winkels weten te winden, afrekenen en weten of het wisselgelld juist is teruggegeven.

- Gedeeltelijk in staat tot boodschappen doen: betrokkene zal bij enkele bovengenoemde handelingen hulp nodig hebben.

- Niet in staat tot boodschappen doen: betrokikene zal bovengenoemde handelingen niet of alleen onder begeleiding kunnen verrichtern.

ad 43: Onder in staat zijn om zell lemand op te bellen worden alle handelingen verstaan die verricht moeten worden om met een telefoonapparaat (b.v. vanuit een telefooncel) een gesprek te kunnen woeren.

- Goed in staat zelf te telefoneren: betrokkene zal belangrijke telefoonnummers kunnen opzoeken of onthouden, hoorn van de haak nemen, met gepast geld betalen, ciffers in de goede volgorde kiezen, en voor een ander begrijpelijke intormatie kunnen overbrengen (b.v. ik kom morgen op bezoek).

- Gedeeltelijk in staat zell te telefoneren: betrokkene zall bil een enkele handeling hulp nodig hebbern.

- Niet in staat zell te telefoneren: betrokkene zall bij bijna alle handelingen hulp van anderen nodig hebben, of geen informatie kunnen overbrengen. 


\section{$-280-$}

\section{BDLAGE 3}


VRAGENLIJST ONDERZOEK LONG-STAY PSYCHIATRIE (VOL III)

PATIENTNUMMER:

NAAM INSTELLING:

NAAM AFDELING:

1. VINDT U DE HUISKAMER OP LEUK?

\begin{tabular}{|l|l|l|l|}
\hline $\begin{array}{l}\text { HELEMAAL } \\
\text { NIET } \\
\text { LEUK }\end{array}$ & $\begin{array}{l}\text { EEN BEET.JE } \\
\text { LEUK }\end{array}$ & $\begin{array}{l}\text { NOGAL } \\
\text { LEUK }\end{array}$ & $\begin{array}{l}\text { HEEL } \\
\text { LEUK }\end{array}$ \\
\hline
\end{tabular}


2. ZOU U GRAAG VAN

WEG WILLEN?

\begin{tabular}{|l|l|l|l|}
\hline $\begin{array}{l}\text { ZEKER } \\
\text { NIET }\end{array}$ & $\begin{array}{l}\text { WAARSCHIJNLIJK } \\
\text { NIET }\end{array}$ & $\begin{array}{l}\text { WAARSCHIJNLIJK } \\
\text { WEL }\end{array}$ & $\begin{array}{l}\text { ZEKER } \\
\text { WEL }\end{array}$ \\
\hline
\end{tabular}

3. HOE PRETTIG VINDT U HET OP

Al

\begin{tabular}{|l|l|l|l|}
\hline HELEMAAL & EEN BEETJIE & NOGAL & HEEL \\
NIET & PRETTIG & PRETTIG & PRETTIG \\
PRETTIG & & & \\
\hline
\end{tabular}

4. BENT U TEVREDEN MET HET LEVEN DAT U MOMENTEEL OP Al LEIDT?

\begin{tabular}{|l|l|l|l|}
\hline $\begin{array}{l}\text { HELEMAAL NIET } \\
\text { TEVREDEN }\end{array}$ & $\begin{array}{l}\text { EEN BEETJE } \\
\text { TEVREDEN }\end{array}$ & $\begin{array}{l}\text { NOGAL } \\
\text { TEVREDEN }\end{array}$ & $\begin{array}{l}\text { HEEL } \\
\text { TEVREDEN }\end{array}$ \\
\hline
\end{tabular}


5. VINDT U HET WEL EENS VERVELEND OP

\begin{tabular}{|l|l|l|l|}
\hline NOOIT & ZELDEN & VAAK & ALTIJD \\
\hline
\end{tabular}

6. VOELT U ZICH GEWOONLIJK OP UW GEMAK IN DE OMGANG MET MEDEBEWONERS?

\begin{tabular}{|l|l|l|l|}
\hline NOOIT & ZELDEN & VAAK & ALTIJD \\
\hline
\end{tabular}

7. ZOU U MET DE NODIGE HULP ZELFSTANDIG WILLEN WONEN?

\begin{tabular}{|l|l|l|l|}
\hline $\begin{array}{l}\text { ZEKER } \\
\text { NIET }\end{array}$ & $\begin{array}{l}\text { WAARSCHIJNLIJK } \\
\text { NIET }\end{array}$ & $\begin{array}{l}\text { WAARSCHIJNLIJKK } \\
\text { WEL }\end{array}$ & $\begin{array}{l}\text { ZEKER } \\
\text { WEL }\end{array}$ \\
\hline
\end{tabular}


8. VINDT UI DE MEDEBEWONERS OP

IN HET ALGEMEEN AARDIGER DAN BEWONERS VAN ANDERE AFDELINGEN?

\begin{tabular}{|l|l|l|l|}
\hline NOOIT & ZELDEN & VAAK & ALTIJD \\
\hline
\end{tabular}

9. ZOU U HET PRETTIG VINDEN OM BUITEN TE WERKEN?

\begin{tabular}{|l|l|l|l|}
\hline $\begin{array}{l}\text { HELEMAAL } \\
\text { NIET } \\
\text { PRETTIG }\end{array}$ & $\begin{array}{l}\text { EEN BEETJE } \\
\text { PRETTIG }\end{array}$ & $\begin{array}{l}\text { NOGAL } \\
\text { PRETTIG }\end{array}$ & $\begin{array}{l}\text { HEEL } \\
\text { PRETTIG }\end{array}$ \\
\hline
\end{tabular}

10. HOE VINDT U DE SFEER OP

Al ?

\begin{tabular}{|l|l|l|l|}
\hline SLECHT & $\begin{array}{l}\text { VRIJ } \\
\text { SLECHT }\end{array}$ & $\begin{array}{l}\text { VRIJ } \\
\text { GOED }\end{array}$ & GOED \\
\hline
\end{tabular}


11. ZOU U HET VERVELEND VINDEN ALS IEMAND TEGEN U ZEI DAT U BEST UIT WEG ZOU KUNNEN?

\begin{tabular}{|l|l|l|l|}
\hline $\begin{array}{l}\text { HELEMAAL NIET } \\
\text { VERVELEND }\end{array}$ & $\begin{array}{l}\text { EEN BEETJE } \\
\text { VERVELEND }\end{array}$ & $\begin{array}{l}\text { NOGAL } \\
\text { VERVELEND }\end{array}$ & $\begin{array}{l}\text { HEEL } \\
\text { VERVELEND }\end{array}$ \\
\hline
\end{tabular}

12. VOELT UZICH OP THUIS?

\begin{tabular}{|l|l|l|l|}
\hline NOOIT & ZELDEN & VAAK & ALTIJD \\
\hline
\end{tabular}

13. ZIJN UW MEDEBEWONERS OVER HET ALGEMEEN AARDIG VOOR U?

\begin{tabular}{|l|l|l|l|}
\hline NOOIT & ZELDEN & VAAK & ALTIJD \\
\hline
\end{tabular}


14. ZOU U SAMEN MET ANDERE MENSEN BUITEN WILLEN WONEN?

\begin{tabular}{|l|l|l|l|}
\hline $\begin{array}{l}\text { ZEKER } \\
\text { NIET }\end{array}$ & $\begin{array}{l}\text { WAARSCHIJINLIJK } \\
\text { NIET }\end{array}$ & $\begin{array}{l}\text { WAARSCHIJNLIJK } \\
\text { WEL }\end{array}$ & $\begin{array}{l}\text { ZEKER } \\
\text { WEL }\end{array}$ \\
\hline
\end{tabular}

15. VINDT U HET VERVELEND HIER TE MOETEN WONEN?

\begin{tabular}{|l|l|l|l|}
\hline HELEMAAL & EEN & NOGAL & HEEL \\
NIET & BEETJE & VERVELEND & VERVELEND \\
VERVELEND & VERVELEND & & \\
\hline
\end{tabular}

16. ZOU U HET PRETTIG VINDEN OM BUITEN

TE GAAN WONEN?

\begin{tabular}{|l|l|l|l|}
\hline HELEMAAL & EEN & NOGAL & HEEL \\
NIET & BEETJE & PRETTIG & PRETTIG \\
PRETTIG & PRETTIG & & \\
\hline
\end{tabular}


17. KUNT U MET PROBLEMEN BIJ IEMAND VAN HET PERSONEEL TERECHT?

\begin{tabular}{|l|l|l|l|}
\hline NOOIT & ZELDEN & VAAK & ALTIJD \\
\hline
\end{tabular}

18. HEBT U WEL EENS HET IDEE, DAT UW BESTE VRIENDEN EIGENLIJK OP

\begin{tabular}{|l|l|l|l|}
\hline NOOIT & ZELDEN & VAAK & ALTIJD \\
\hline
\end{tabular}

19. HEBT U WEL EENS HET GEVOEL DAT U LIEVER ERGENS ANDERS ZOU GAAN WONEN?

\begin{tabular}{|l|l|l|l|}
\hline NOOIT & ZELDEN & VAAK & ALTIJD \\
\hline
\end{tabular}


20. HOE KOMT UDE WEEKEINDEN OP DOOR?

\begin{tabular}{|l|l|l|l|}
\hline SLECHT & $\begin{array}{l}\text { VRIJ } \\
\text { SLECHT }\end{array}$ & $\begin{array}{l}\text { VRIJ } \\
\text { GOED }\end{array}$ & GOED \\
\hline
\end{tabular}

21. DENKT U WEL EENS DAT U VOORLOPIG OP ZULT MOETEN BLIJVEN?

\begin{tabular}{|l|l|l|l|}
\hline NOOIT & ZELDEN & VAAK & ALTIJD \\
\hline
\end{tabular}

22. BENT U TIJDENS HET VERBLIJF IN ER OP VOORUIT GEGAAN?

\begin{tabular}{|l|l|l|l|}
\hline $\begin{array}{l}\text { HELEMAAL } \\
\text { NIET }\end{array}$ & WEINIG & NOGAL & VEEL \\
\hline
\end{tabular}


23. ALS FAMILIE OF KENNISSEN U EEN BEETJE ZOUDEN HELPEN, ZOU U DAN BEST VAN AI WEG WILIEN?

\begin{tabular}{|l|l|l|l|}
\hline $\begin{array}{l}\text { ZEKER } \\
\text { NIET }\end{array}$ & $\begin{array}{l}\text { WAARSCHIJNLIJK } \\
\text { NIET }\end{array}$ & $\begin{array}{l}\text { WAARSCHIJNLIJK } \\
\text { WEL }\end{array}$ & $\begin{array}{l}\text { ZEKEA } \\
\text { WEL }\end{array}$ \\
\hline
\end{tabular}

24. VINDT U DE MENSEN DIE OP WERKEN AARDIG?

\begin{tabular}{|l|l|l|l|}
\hline HELEMAAL & EEN & NOGAL & HEEL \\
NIET & BEETJE & AARDIG & AARDIG \\
AARDIG & AARDIG & & \\
\hline
\end{tabular}

25. ZOU U HET PRETTIG VINDEN OM WAT MEER DINGEN ZELF TE GAAN REGELEN?

\begin{tabular}{|l|l|l|l|}
\hline HELEMAAL & EEN & NOGAL & HEEL \\
NIET & BEETJE & PRETTIG & PRETTIG \\
PRETTIG & PRETTIG & & \\
\hline
\end{tabular}


$-291=$

BULAGE 4 


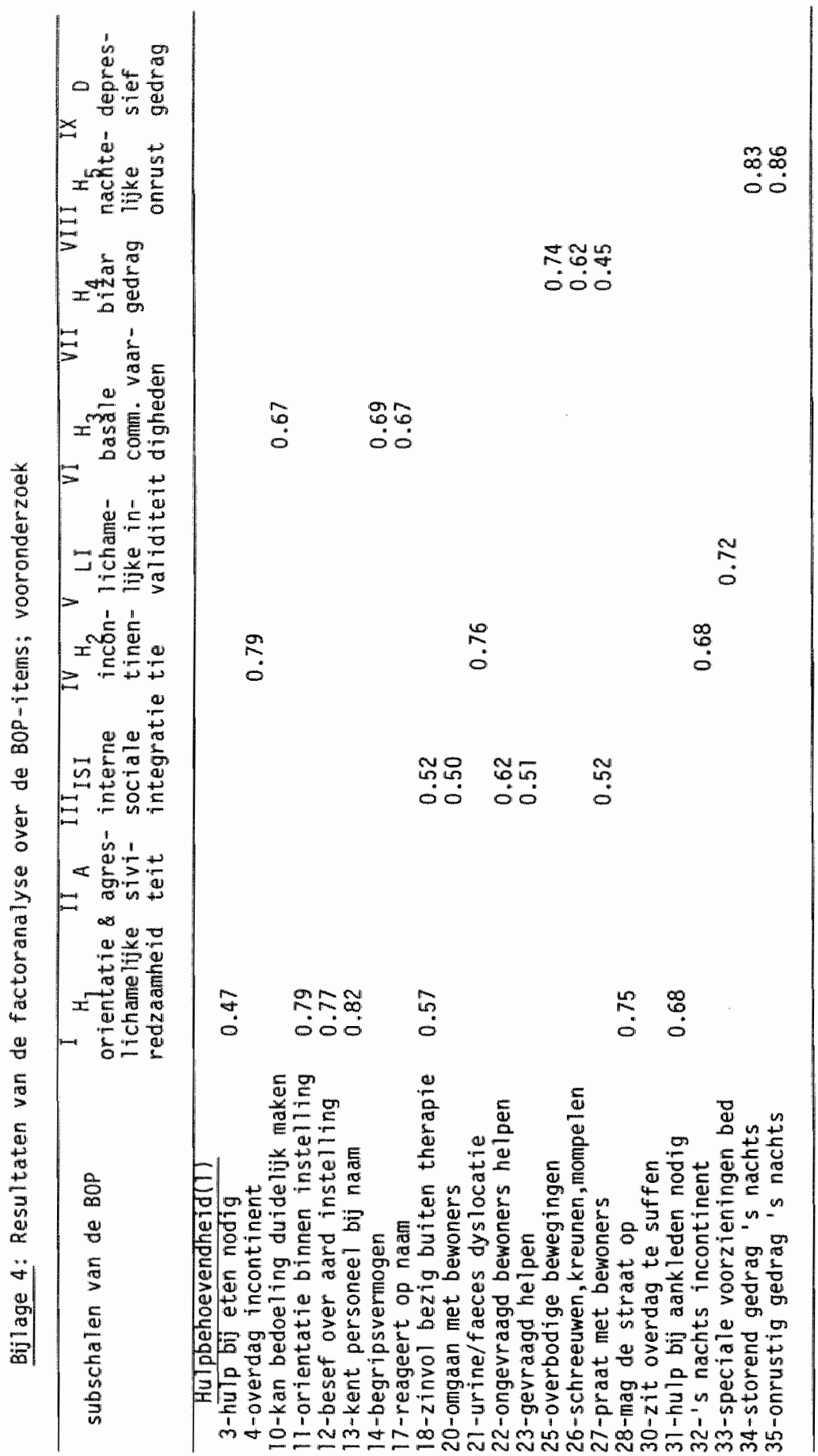




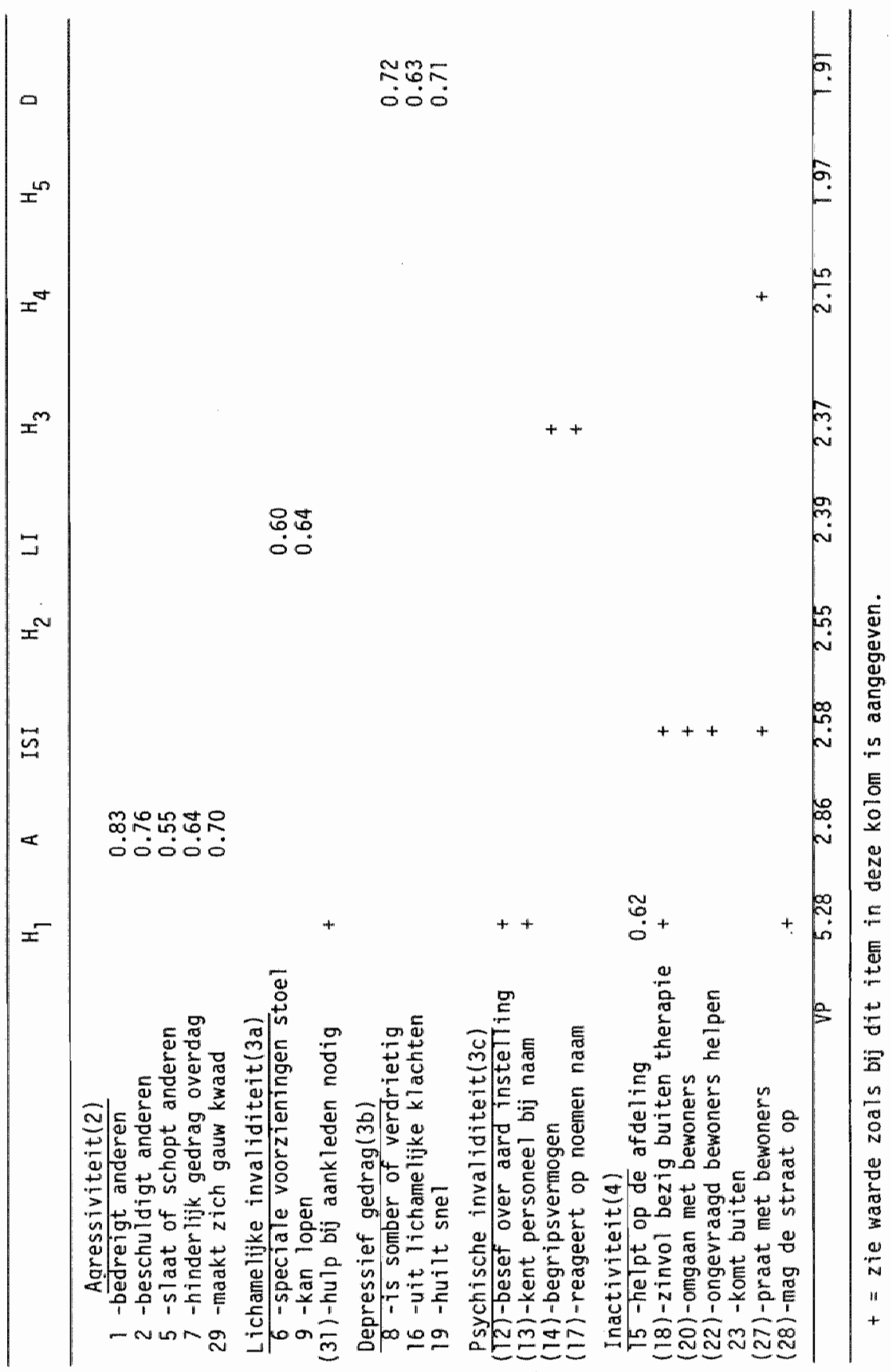


$-294-$

BDLAGE 5 


\section{Bijlage 5}

Instellingenrespons: Beschermende woonvormen.

Aselecte steekproef van 36 instellingen van de 120 (T.S.M.D.lijst). Van deze 36 steekproefinstelingen vielen 6 na een eerste contact met de insteliling af:

- 2 instellingen omdat $\mathrm{z} i \mathrm{j}$ inmiddels niet via de TSMD werden gefinancierd.

- I insteliing was inmiddels opgeheven.

- 1 instelling omdat deze had deelgenomen aan het vooronderzoek. en

- 2 instellingen omdat zij bijna uitsluitend functioneerden voor geestelijk gehandicapten of demente bejaarden.

De gecorrigeerde steekproef van instellingen omvatte dus in total 130 beschermende woonvormen.

Respons.

- 21 instellingen met doelgroepbewoners

- 2 instellingen zonder doelgroepbewoners

Non-respons.

- 4 instellingen (bewomers zagen van deelname af)

- 3 instellingen (leiding achtte deelname niet wenselijk).

\section{Instellingenrespons: Psychiatrische dagziekenhuizen}

Van de 62 ziekenfondserkende instelilingen voor psychiatrische dagbehandeling (Ministerie WWC, 1983b) werden 37 instellingen tot het steekproefkader gerekend en 25 niet. Van de laatstgenoemde voorzieningen waren io categoriaal (kinder- en jeugdpsychiatrie e.d.) en vervulden 15 voornamelijk of uitsluitend een primaire dagbehandelings functie (Scheffer \& Van den Hout, 1981). Het totaal te benaderen voorzieningen was dus 37 .

\section{Respons}

- 16 instellingen met doelgroeppatiënten

- 15 instellingen zonder doegroeppatiënten

Non-respons:

- 4 instelingen hadden naar eigen opgaf vanwege personeelugebrek onvoldoende tijd voor deelname

- 2 instellingen namen reeds deel aan een ander onderzoek en hadden hierdoor naar eigen opgaf onvoldoende tijd voor deelname. 
$-296-$

BLLAGE 6 
Bijlage 6: Correlatiematrix voor de variabelen van de multiple logistische regressie.

\begin{tabular}{lrrrrrrrrr}
\hline & LFT & \multicolumn{1}{l}{ PSV } & \multicolumn{1}{c}{ THM } & AGR & VBD & DOA & HA & HO & SZF \\
\hline LFT & 1.00 & & & & & & & & \\
PSV & -.43 & 1.00 & & & & & & & \\
THM & .44 & -.24 & 1.00 & & & & & & \\
AGR & .06 & .19 & .05 & 1.00 & & & & & \\
VBD & .53 & -.46 & .41 & -.03 & 1.00 & & & & \\
DOA & .34 & -.31 & .18 & -.10 & .22 & 1.00 & & & \\
HA & -.08 & .05 & -.07 & -.14 & -.22 & -.08 & 1.00 & & \\
HO & .29 & -.13 & .18 & .08 & .26 & .13 & -.40 & 1.00 & \\
SZF & -.02 & .19 & -.11 & -.01 & -.03 & -.23 & .03 & -.05 & 1.00 \\
\hline
\end{tabular}


$-298-$

BULAGE 7 
Bijlage 7: Gebruikte afkortingen.

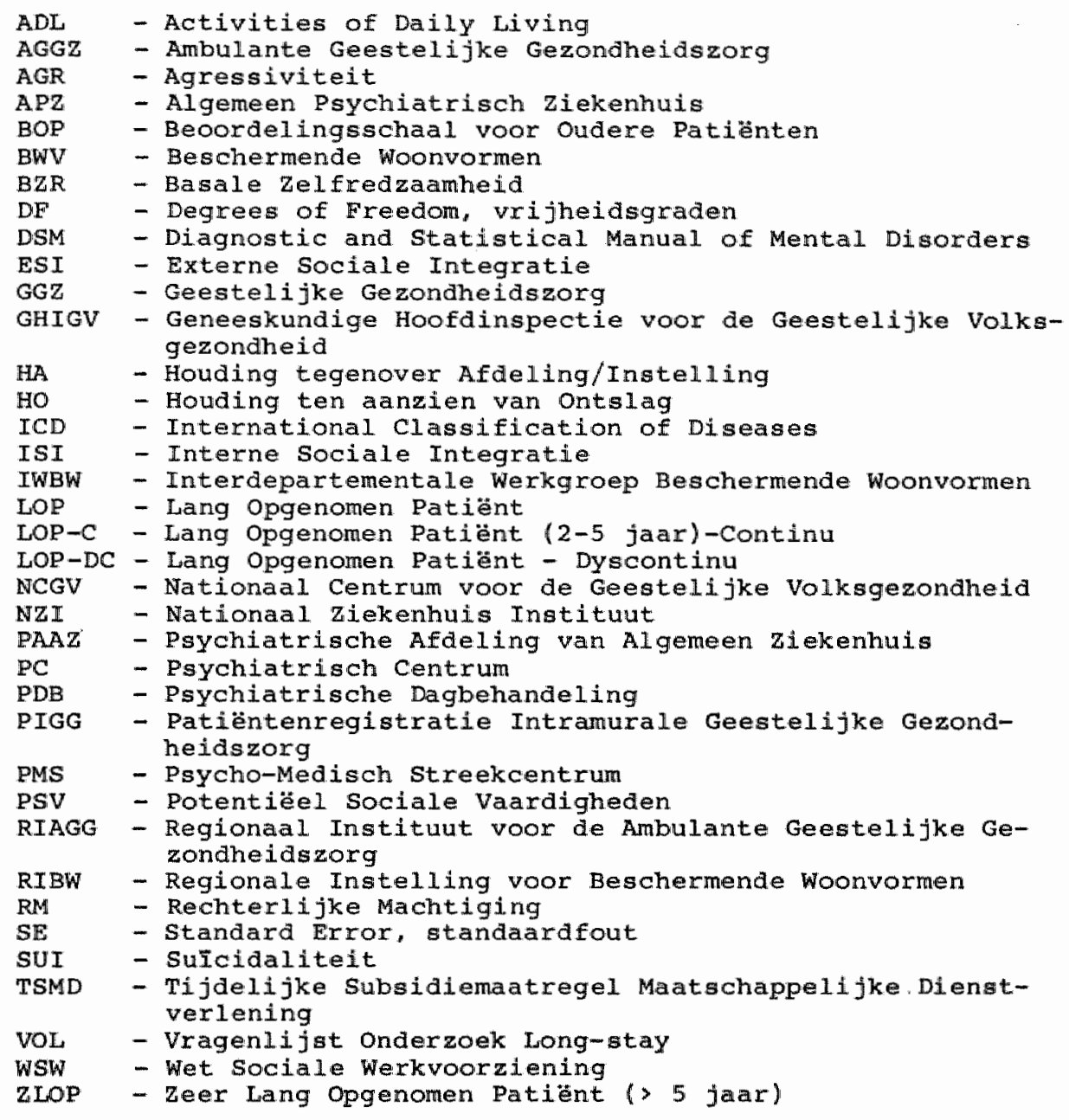


$-300-$

SUMMARY 
Summary

design and sampling

About $55 \%$ of the patients in the 43 Dutch mental hospitals remain there continuously for more than two years. With 10850 patients they still outnumbered, at the end of 1984, the short-stay and medilum-stay patients in these institutions. Their chance of discharge and alternative care is small without a significant change towards more rehabilitative attitudes and programs inside as well as outside the mental hospitals.

In this thesis an attempt is made to study one of the essential questions in this respect: what are the main reasons for staffmembers of mental hospitals to consider long-stay patients as eligible or not for discharge and alternative care?

Long-stay patients were defined in this study as:

- patients who were hospitalized continuously in a mental hospital for a period of two years or longer;

- patients who were admitted twice or more in mental hospitals or psychiatric wards of general hospitals in the last five years and who were inpatients for a cumulative period of three years or longer.

Senile patients and profoundly mentally retarded patients were excluded from this study.

First of all it was necessary to assess which pisychlatric inpatients could be considered eligible for discharge and alternative care. Given this objective the attending psychiatrists or psychologists and nurses were requested to judge independently on the feasability of discharge.

Only if both staff-members agreed that the patient could be discharged to independent living or to appartments shared with other patients, day-treatment or sheltered homes, the patient was defined and counted as a potential discharge. A "yes" of one of the raters had to correspond with at least a "perhaps" of the other rater. With this approach it was possible to identify in mental hospltals a potential discharge- and alternative caregroup of longstay patients. 
In addition, residents of sheltered homes and patients in daytreatment, all previously longstay inpatients, were included in this study as a reference-group.

This design offered the opportunity to determine the clinical signiflcance of certain factors for assessment and decisionmaking in three different way's:

1 - By comparing longstay patients in mental hospitals who are and who are not eligible for discharge according to the attending psychiatrists and nurses;

2 - By comparing longstay hospltal patients and daycare patients with longstay inpatient careers;

3 - By comparing longstay hospital patients and residents of sheltered homes with longstay inpatient careers.

Specifically, a number of patient-characteristics was tested in their relation with the established assessment for discharge. Some questions concerning factors related to characteristics of the ward and family were studied as well.

These patient-characteristics were: sex, age, marital state, psychiatric diagnosis, suicidal behaviour, agressiveness, physical handicaps concerning seeing, speaking, hearing and walking, problems with activities of daily life (basic persondi skills), social skills, internal and external social integration, and the attitudes of patients towards discharge and their ward.

As ward-variables were counted: length of inpatient stay, perceptions and motiwation of the staff with regard to discharge, and length of stay of fellow-patients.

The family-variables were restricted to: the number of living familymembers and their attitude with regard to a possible discharge of the patient as observed by the attending psychiatrist.

The information related to the above-mentioned variables was collected by means of standardized questionnalres in mental hospltals, as well as in daycare centers and sheltered homes. Three questionnaires had to be completed for each patient by the attending psychiatrist (psychologist), nurse and patient. For the 
patient this was done by means of an interview. The questionnaire for the patient consisted of 10 items measuring discharge-attitudes and of 15 items wilh regard to the perception of the ward or institution. The patients were interviewed by ten experienced psychiatric nurses, members of the research-team. The interviews took place in separate rooms.

The patients were selected by a procedure of two-stage random sampling. Five mental hospitals, 16 daycare centers and 21 sheltered homes did participate in this study at the end of the first stage. The second stage consisted of selection, at random, of 808 patients in these institutions. The data concerning the selected patients were collected in the period of May" 1984 till August, 1985 .

For 381 patients ( $75 \%$ ) in mental hospitals both questionnaires of the staff were returned. The patient-interviews were completed for $60 \%$ of the hospitalsample. For longstay patients who were dyscontinuously admitted a low response only was achieved with regard to the interview.

The response to the questionnaires for patients in daycare and sheltered homes was satisfactory: all information was received for three-quarter $(76 \%)$ of these patients.

\section{results}

During a long residence in mental hospitals the prospect of alternative care did not vanish for a number of patients. The attending psychiatrists and nurses agreed for 30 percent of the 381 longstay patients in the study that these persons dould just as well live, more independently, in less sheltered conditions. The assessed need for alternative mental health care varied much within this group of 116 patients.

About 7 percent of the total study population was assigned to independent lodging or to living together with other patients in appartments or houses. Most of these patients were recommended for support by outreaching mental health care. Another 2 percent were considered eligible for discharge to a psychiatric daycenter or psychiatric hostel. 
Most patients, finally, were indicated for residence in sheltered homes: 12 percent in facilities outside of the grounds of mental hospitals, and 10 percent in small residential facilities within the border of the mental hospital site.

Much attention was given in this study to the gkilis of longstay patients. We distinguished by concept and factoranalysis four types of skilis: basic personal skills (14 items), social skilis (4 items). Internal ( 6 items) and external social integration (20 items). These four scales were mutually dependent as indicated by linear correlation.

In the scale measuring basic personal skills items were included re dressing, walking, continence, sense of direction and linguistic competence. About 15 percent of al1 the longstay patients were seriously handicapped in their baslc personal skills. These patients were very rarely considered eligible for alternative care.

The availability of basic personal skills turned out to be a necessary, but not an exclusive condition for the assignment of patients to alternatiwe care. For living a more independent life social skills like verbal comunication in daily life-interactions, handling money, using the telephone and public transportation, shopping and preparing simple meals are at least as important. About half (47\%) of the study-population had serious difficulties with such social skills. Out of the patients with good sacial skills, however, 57 percent were considered eligible for discharge to alternative care.

The concepts internal and external social integration refer to:

(a) the level of cooperative behaviour and social adaptation within the institution, and

(b) the frequency and intensity of contacts with persons outside the hospital.

Theae two types of social integration were strongly correlated $(r=66)$. But there were still differences between internally and externally well-integrated patients. The group of externally 
well-integrated patients consisted significantly more of men, were younger, had a shorter inpatientstay, and had better basio personal and social skills.

A good score on each skili-index contributed to a more positive judgement about discharge to alternative care. Patients with just as good basic personal skills had a smaller chance for discharge than patients who had not only good basic personal skills but also good social skills. The patients, finally, with an optimal skillspattern had with 64 percent a good chance of being indicated for alternative care. One patient out of seven had such an optimal skillspattern.

Suicidal behaviour was a very uncommon phenomenon in the group of longstay patients, and the results of the study did not confirm a negative relation between suicidal behaviour and dischargeeligibility. Patients with agressive behaviour, on the other hand, were indicated much less for alternative care.

The judgement on potential discharge by staff-members was heavily influenced by the age of patients. Ellderly patients had a significantly smaller chance of being idicated for alternative care than younger patients even if they did not differ with regard to skills, diagnosis, agressive or suicidal behaviour and length of inpatientstay. The elderly schizophrenic patients in particular, had a very small chance to become eligible for alternative care.

Group I (elderly schizophrenic patients): about 15 percent of the longstay patients were 65 years or older and had a diagnosis of schizophrenia. Half of these patients had major deficiencles in basic personal skilis, and almost everybody (95\%) had serious problems with their social skilis. Most of the patients were moderately or scarcely integrated in the social life of the institution ( 898 ) or in the community outside of the mental hospital ( 818$)$. Only 6 percent of these patients were considered candidates for alternative care. 
Group II (elderly mon-schizophrenic patients) just as many patients in the sample (15\%) were elderly but were not diagnosed as chizophrenic. Although they were comparable by age with the patilents of Group $I$, they differed substantially with regard to sk111s. Group II-patients were significantly less handicapped in their basio personal and soclal skills, and showed a better particlpation in community life, inside and outside the hospital. About 20\% of these patients were considered eligible for discharge to alternative care.

Group III (schizophrenic patients under 65 years of age): about 36 percent of the longstay patients were younger schizophrenic patients. Most of them ( 808$)$ had no deficiencies in their basic personal skills, and for half of the patients the social skills were not limited. In comparison with the elderly patients of Group II they had more restraints (29\%) in participating socially within the hospital. The younger schizophrenic patients were, on the other hand, better integrated in social activities outside the mental hospital (58\%). About 30 percent of these patients were eligible for alternative care according to the judgement of the psychiatrist and nurse.

Group IV (non-schizophrenic patients under 65 years of age): about 34 percent of the longstay patients belonged to this group. The non-schizophrenic patients under 65 years of age contrasted sharply with the above mentioned groups of patients with regard to now prospects for care. Almost half of the patients (498) were indicated by their staff for transfer to an alternative careseting. Most of these patients were not handicapped in their basic personal skills, and more than half of them had good social skills. They were also better integrated in the social life of the mental hospltal than the younger schizophrenic patients. Almost twothird of the patients still had regular contacts with persions who lived outside mental hospitals. 
The longstay patients themselves were interviewed in the study about attitudes towards possible discharge and their perception of the social climate of the ward. It was found that 38 percent of the patients had positive attitudes towards discharge. Just as many patients (36\%) had ambivalent feelings, whereas 26 percent of the patients were unfavourably disposed towards discharge. Especially the hospital-residents with an impatientstay of ten years or longer were strongly attached to the present situation and did not show any inclination towards discharge. This result was consistent for different groups of patients according to sex, age, marital state, psychiatric diagnosis, physical handicaps, skilis and level of social integration.

The results of this study indicate that length of stay is not only a sign of the seriousness and chronicity of psychiatric illness, but also reveals in many cases, the preference of patients to remain in hospital.

Most of the longstay patients $(76 \%)$ in our sample were residents of wards and units with a limited turn-over of patients.

The other patients (24\%) of our sample lived in units together with more recently admitted patients. In these units more than 30 percent of the fellow-patients had a hospital-stay of less than one year.

The patients who were living in the last mentioned type of unit had a far better chance (53\%) of being considered eligible for discharge. This relation was less strong after controlling for potential confounders as age, length of stay and social skills, bus was still noticeable. A posalble explanation for this phenomenon is that the staff of units with more discharges have more experience and better contacts with aftercare services of the hospital, sheltered homes, psychiatric daycare facilities and the regional institutes for ambulatory mental health care. 

Meindert Jan Haveman werd op 15 juni 1949 geboren te Muntendam(Gr.). In verband met de benoeming van zijn vader als predikant in West-Berlijn verhuisde hij in 1956. In 1971 behaalde hij in West-Berlijn het staatsexamen gymnasium, warna hij aan de Rijksuniversiteit Groningen sociologie ging studeren. Na het verkrijgen in 1976 van het doctoraalexamen in de medische sociologie, met als bijvakken klinische psychologie en sociale psychiatrie, werkte hij van 1976 tot en met 1981 als wetenschappelijk medewerker bij de afdeling Onderzoek van de Geneeskundige Hoofdinspectie voor de Geestelijke Volksgezondheid. Met ingang van het jaar 1982 is hij als universitair docent verbonden aan de vakgroep Epidemiologie/Gezonaheidszorgonderzoek * 